Hanna Edit, Kónya

\title{
The emergence of a transnational elite
}

A methodological approach for the definition and identification of the Csángó elite. 
Sociology Doctoral School

Corvinus University of Budapest

Tutors: $\quad$ Letenyei László, Ph.D.

Molina, José Luis, Dr. Prof.

(C) Hanna Edit, Kónya 2012 


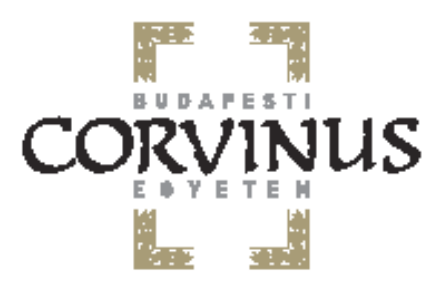

\section{Kónya Hanna Edit}

\section{The emergence of a transnational elite}

A methodological approach for the definition and identification of the Csángó elite. 1

Phd disszertáció

\footnotetext{
${ }^{1}$ A disszertáció a TÁMOP-4.2.1.B-09/1/KMR-2010-0005 azonosítójú projektje Hatékony állam, szakértő közigazgatás, regionális fejlesztések a versenyképes társadalomért címet viselő alprojektjének kutatási tevékenysége eredményeként készült. 
"Léptei magánügyek; de szavaiért és útjelzéséért felelös a világnak, melynek kalauzává szegödött."

Babits Mihály: Az írástudók árulása, 8 . 
1. Introduction: The what, why and how of the research......................................... 11

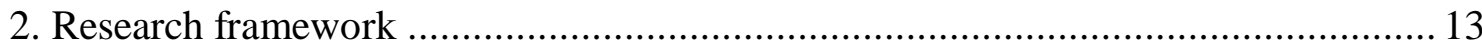

2.1. Socio-demographic outline of the field .........................................................................14

2.2. Literature: Preliminaries of the investigation ...............................................................24

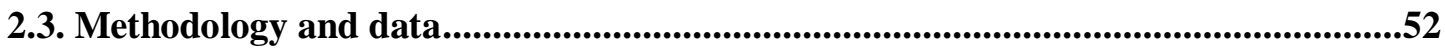

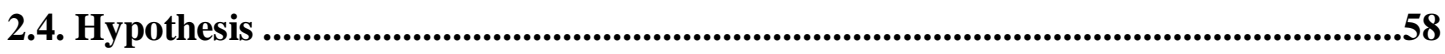

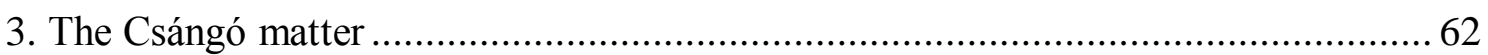

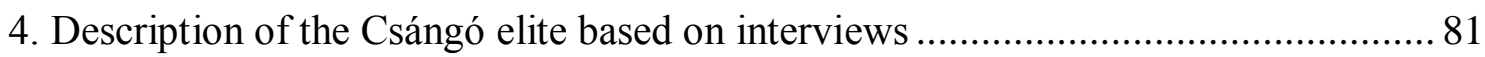

4.1. Is there a Csángó elite? How can we characterize them? .........................................84

4.2. The Catholic Church.............................................................................................99

4.3. Identity or ethnic self-identification of the Csángó elite............................................106

4.4. Romanian - Hungarian self-identification as a conflict .................................................117

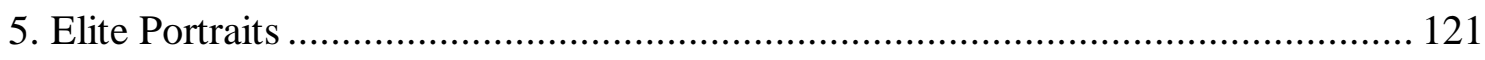

5.1. The pathfinders, the intellectuals of several political regimes ...................................122

5.2. The young intellectual ...............................................................................................129

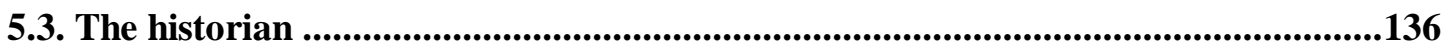

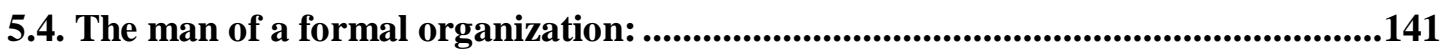

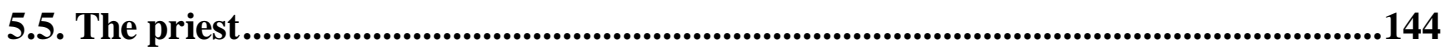

5.6. The advocate.....................................................................................................................149

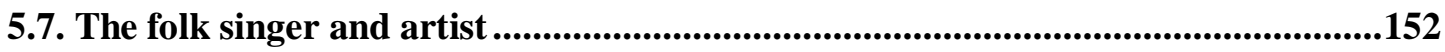

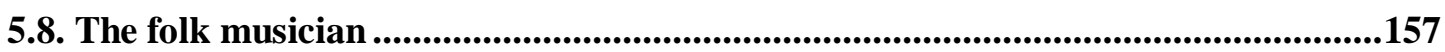

5.9. The local teacher, the reenactmenter......................................................................161

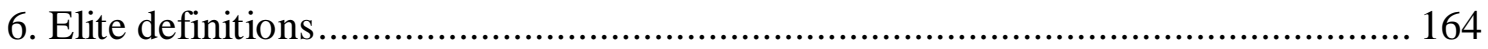

6.1. Hypothesis 1: Elite defined by roles and positions in the Csángó matter cooperation

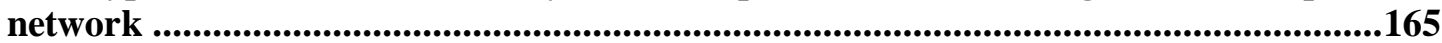

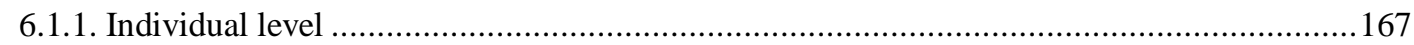

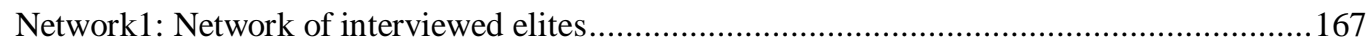

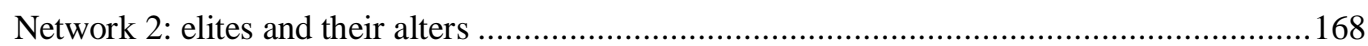

Network 3: Network of elites, representatives (leaders) and alters named by them ..................169

Network 4: Network of elites, representatives (not only leaders) and alters named by them.....170

Network 5: Network of all named in the Csángó matter .........................................................171

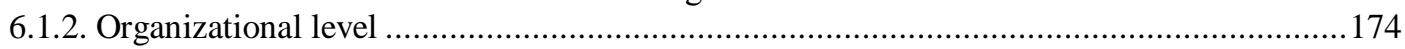

Network 6: Two-Mode network: relations among respondent and their organizational or event

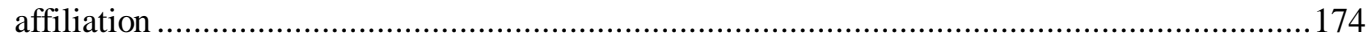

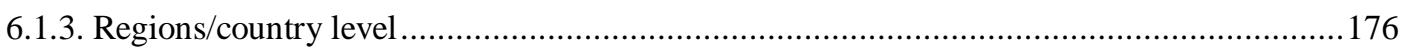

Network 7. Network of all named in the Csángó matter by location.........................................177

6.1.4. Maintaining central position as actors and relations are added ......................................178

6.1.4.1. Central positions at different levels of the network based on Degree ..........................179

6.1.4.2. Central positions at different levels of the network based on In-Degree.......................180

6.1.4.3. Central positions at different levels of the network based on Betweenness ..................181

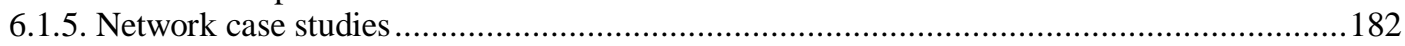

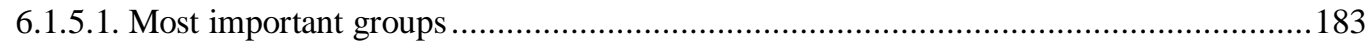

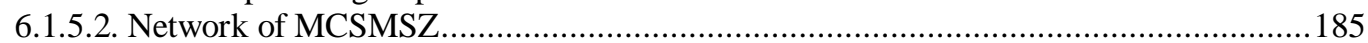

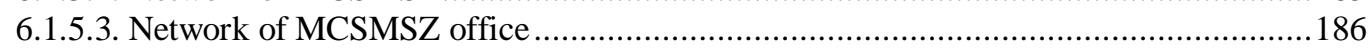

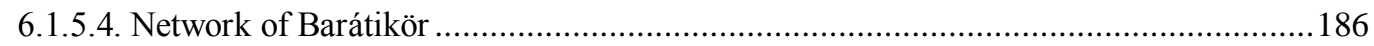


6.1.5.5. Conflict solution (Hypothetical network without the most central actor)

6.2. Hypothesis 2: Elite defined by migration experiences .............................................189

6.2.1. Moldova, Transylvania, Hungary. Places and their roles in the life-path of Csángó elites .. 189

6.2.2. Education versus guest working

6.3. Hypothesis 3: Elite defined by migration experiences and roles and positions in the Csángó matter network 203

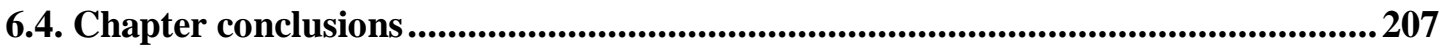

7. Conclusion and further investigation directions ........................................... 213

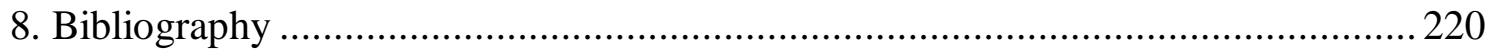

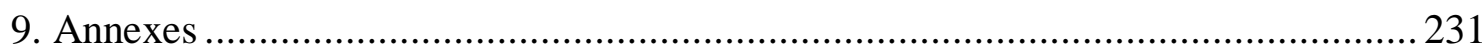

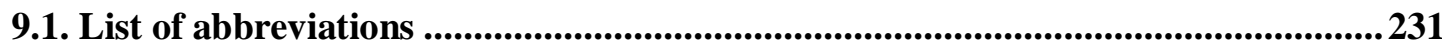

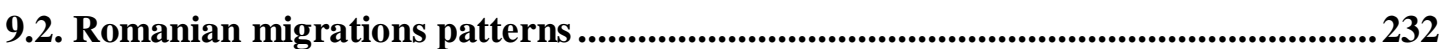

9.3. Main Regions of External Circular Migration from Romanian Rural Population, (Sandu, 2005:563) .................................................................................................................2233

9.4. List of formal and informal organization, groups.....................................................234

9.5. Statistic of MCSMSZ about the Hungarian teaching in Moldova, in the academic year of 2010-2011 ..................................................................................................................2235

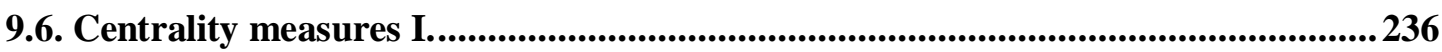

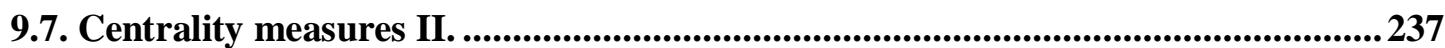

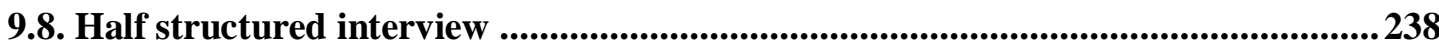

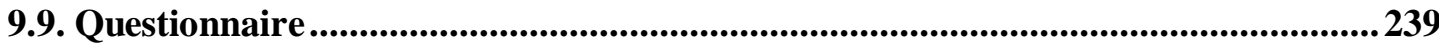

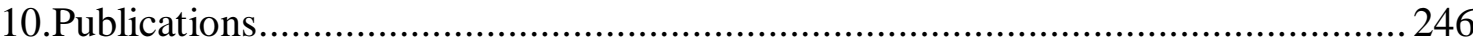




\section{Indices of tables:}

Table 1: The Catholic community in Moldova according to the 1992 and 2002 census 23

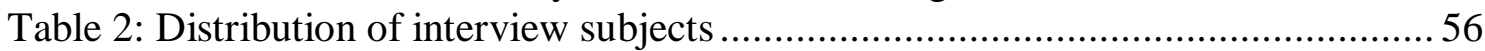

Table 3: Distribution of respondents of the relational data ........................................ 56

Table 4: The place of qualitative research in elite studies, in Légmán (2011:72)......... 57

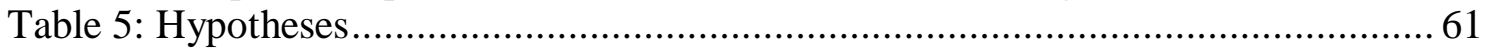

Table 6: Demographic characteristics of respondent .............................................. 82

Table 7: Centrality measures of organizations, foundations and interest groups......... 175

Table 8: Centrality measures of events ............................................................... 176

Table 9: Distribution of respondents based on geographic location and being Csángó or

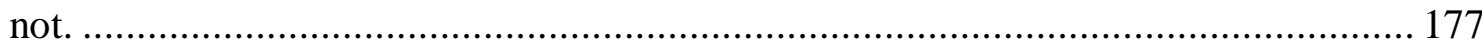

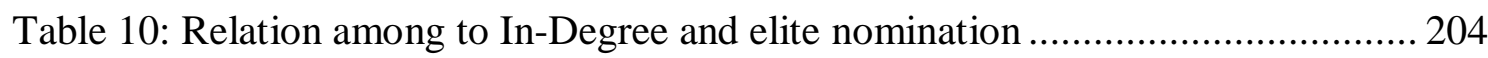

Table 11: Relation among one's geographic location and elite nomination ................. 204

Table 12: Relation among one's geographic location and In-Degree $\left(\mathrm{R}^{2}=0,040\right) \ldots \ldots .205$

Table 13: Relation among Elite nomination, In-Degree and Geographic location ...... 205

Table 14: Relation of Elite nomination, In-Degree and Geographic location layered by

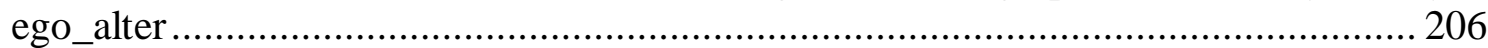

Table 15: Distribution of respondents based on age categories ............................... 209

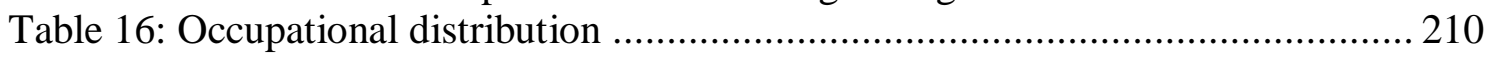

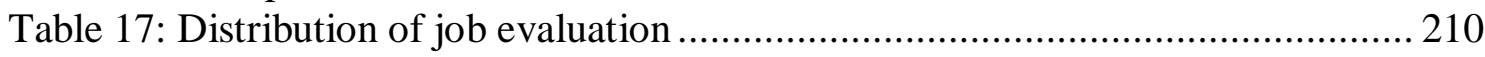

Table 18: Distribution of planning to work abroad .............................................. 210

Table 19: Distribution of the likeliness of mooving abroad ..................................... 211

Table 20: Romanian migration patterns. Translation of (Sandu, 2010: 64-65)

Translation made by Hanna Kónya. 


\section{Indices of figures}

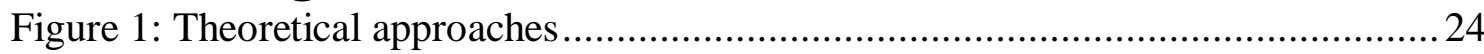

Figure 2: Modeling a Theory of Social Capital. (Lin, 1999:41) ..................................29

Figure 3: N1 total network, N2: ego-network, N3: personal network ........................... 32

Figure 4: Visualization of the migration process among Csángós .............................. 42

Figure 5: Elite characteristics expected by the community and the elite itself .............81

Figure 6: Kinship relations among the members of the Csángó elite ...........................83

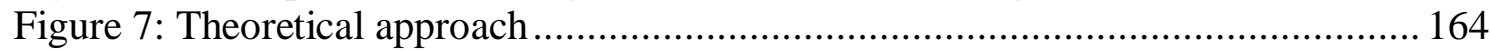

Figure 8: Cooperation network among questioned elite actors .............................. 167

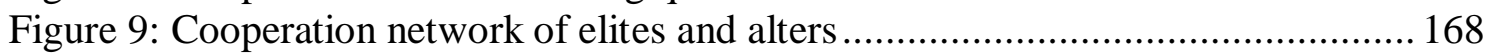

Figure 10: Network of elites, representatives (leaders) and alters named by them ...... 169

Figure 11: Network of elites, representatives (not only leaders) and named alters..... 170

Figure 12: Network 5 Ego-alter and alter -alter relations....................................... 171

Figure 13: Network of organizational affiliation and activity in events .................... 174

Figure 14: Network of all named in the Csángó matter by location and by being Csángó

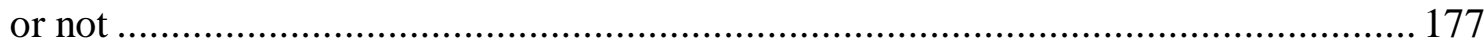

Figure 15: Central positions at different levels of the network based on Degree......... 179

Figure 16: Maintaining central position in networks according to In-degree ............... 180

Figure 17: Maintaining central position in networks according to Betweeness ........... 181

Figure 18: Distribution of nominations based on respect, prestige .......................... 182

Figure 19: Network of most important groups formed by personal relations ............. 183

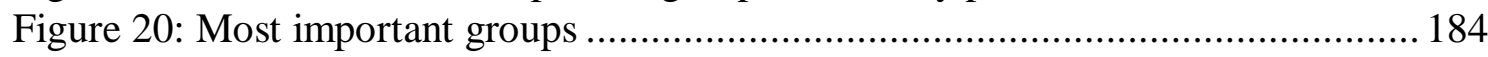

Figure 21: Network of the MCSMSZ members ................................................... 185

Figure 22: Cooperation network of MCSMSZ office employees ............................. 186

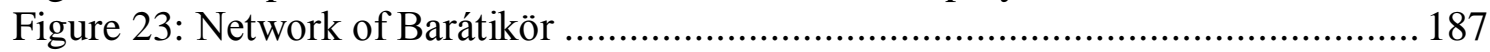

Figure 24: Hypothetical network of the Csángó matter by excluding S10 ................. 188 


\section{Introduction: The what, why and how of the research.}

The summer of 2006 was the first time I went to Moldova to visit some friends, we went to a couple of villages and when we returned to Csíkszereda one of my friends wanted to visit his former teacher Borbáth Erzsébet. Meeting her determined the topic of this thesis, she planted the idea of conducting elite studies among Csángós ${ }^{2}$, telling me that organizing the Hungarian teaching in Csíkszereda at the beginning of the 90s and later in Hungary had the declared role of developing a Csángó intellectual strata.

The research seeks to present those who can shape the public opinion about Csángós, and to show the facts that influence someone to be concerned about his/her cultural heritage, customs and the situation of the home village, how they are becoming known and appreciated by others, what they have to do to enjoy the recognition of others, and so on. Who are the Csángós and how is that possible that their intellectual strata is developed in Transylvania and Hungary, are the questions that trigger the topic of the thesis and also situates it among other elite investigation. Csángós form a very heterogeneous society based on their origins, establishment in Moldova, degree of assimilation, dialect, generation, etc. Although many papers and books were written about this community, even the denomination is complicated. There is no name uniformly accepted by all scientists, and even for insiders selfidentification is often situational and relational. Hungarian and Romanian scholars as well use most frequently the notion of "Csángó", yet they are not necessarily enrolling the same group of people. Religion - being Catholics among the Orthodox majority - is the factor that characterizes them the most, due to this the term of Catholic from Moldova is often used. Accepting this more or less neutral term, neutral by being usable regardless of ethnicity or the level of assimilation, it should be acknowledged that by opting for this name, we are also opting for information loss since the term can't actually describe the internal diversity of the group. Using the term of Csángó is supported by the following two arguments: the investigation refers to the part of the elite that has Hungarian ethnic identity and consciousness and the subjects themselves use the Csángó or CsángóHungarian denomination.

\footnotetext{
${ }^{2}$ As Lükő points out that the Csángó term describes two groups of people: "The literature referring to Transylvania and Bukovina the Csángó name always denoted those Széklers who migrated from Széklerland or lived in the borderline among foreign (Vlach or Saxon) population, the literature relating to the Middle-Moldova on the contrary, called Csángós the non-székler Hungarians from Moldova, and by this name they differentiate the from the széklers settled among them." (Lükő 2002:25)
} 
Elite studies have great heritage in social investigations yet, this investigation is innovative because of the following four factors:

a.) Focuses on a developing elite: Csángós were barely present in the national and international social scientific and public knowledge, they appeared in the Transylvanian and Hungarian scientific scene mostly after the regime change, when several ethnographic and linguistic results were published. A preconception often met in publications focusing on the Csángó society is that it lacks its cohesive, urban citizenry, intellectual, artisan strata. (More details in Pozsony, 2003) Organizing the Hungarian teaching of Csángós in Csíkszereda at the beginning of the 90s had the declared role of developing the Csángó intellectual strata missed by scientists.

b.) Implements the feedback received from the community: The investigation does not approach the elite topic, by speaking about elites, but speaking with elites of a community and speaking about elites with the community as well. Due to the colorful methodology used, important feedback is received, feedback that was necessary in order to have a valid description of the Csángó elite.

c.) Focuses on a transnational elite: Because of the new possibilities brought by the regime change, especially in international migration, social, economic and human capital started to make a difference, to develop the stratification of villages and to layer migrant communities as well. Geographic division to states and regions appears very markedly in social sciences, especially in elite studies where some are seen as elites, leaders, high prestige members, etc. precisely because they are fulfilling special roles and have specific jobs inside of well defined geographic boundaries. If Hungarian teaching was the channel that allowed the development of the elite, it should be acknowledged that the Csángó elite is transnational as it considers its development and the residence of its members and that the closed or semi-closed concentricity which starts in Moldova, having major stations in Csíkszereda should be included.

d.) Due to previously presented characteristics the level of the research is not restricted geographically on one region. Methods of identifying the elite are typical for the local level, elites are elites on a local level, some on a regional level, but geographically they are present in a transnational level. The transnational space from the title can be understood as being not only the conglomeration of the main stations in the lifepath of several Csángós, and not only the space of elite development, but both.

Summarizing the entire research in one sentence would be:

"Why are exactly these individuals seen/named as the Csángó elite?" 


\section{Research framework}

It might be obvious from the guidelines of this research proposal that even the topic of Csángó (elite) generates different points of views and debates. There are scientific researchers who -even if they do not wish to demonstrate - start their study from the fact that the Catholics from Moldova are either Hungarians or Romanians. Another preconception often met is that the Csángó society doesn't have its cohesive, urban citizenry, intellectual, artisan strata. (More details in Pozsony, 2003)

In the Hungarian social sciences - from Hungary and Transylvania as well - the Csángó topics are studied mostly from the point of view of History, Ethnography or Sociolinguistic. Current research is innovative not only from the new insight applied to this field, but in the same time can answer several questions such as how a first generation elite is developed, what role is played by migration and migration patterns in this process, and how these elites are connected and seen by the community. The relevancy of the research is underlined by the fact that papers which at least tangentially discuss the Csángó society structure approach from the point of view of poverty, creating a village picture with identity lost, inhabitants who live under total political oppression, undermined by ethno-political purposes/goals.

With my research I do not wish to deny these research results, simply to point out that after the regime change, local elites slowly appeared and to show how these changes layer the Csángó community. 


\subsection{Socio-demographic outline of the field}

Motto:

„[...] nagytátámnak es a nagytátája máséltá, hogy réges-régen eccer úgy vót, hogy az emberek áltértek z Istántől, s pogányakat látérdgyülvál imádkoztak. S látta z Istán, hogy jó népjá álfordult töllá, nagy szározságot küldött riájuk, s hét ásztándöig e csepp ásö nám vót, s ulyan éjség vót, hogy a jó nép hasszú utnak kált. S házaikat, vagyonukat álárulták az idágányeknák, kaptak értá lovakat, ünöket, kácskéket, hoj lejen tájük a gyármekecskéknák, s hoj húzzák a nagy kortos szákereket. S filikbá az ágésziknák csángöket raktak, hogy ha igeny másszá menná valaki, tudgya, hogy márrá mennák a többiák, hoj örökki mágkapják egyikamást. Ha bornyúcska vaj a kácská álfutkározznak, akkor tutták hul kárássék őket a gazdája, mát annyitcar csánget a filj, hányszor mágmozdultak. Ottoti es örökké teszünk a filikbá csángöt.

Menták hasszú, hasszú után, hályát találni magiknak a világba. S hugy menták, ügy csöngátták, hogy csánglet töllük az út, hul menták. S ha idágeny népekvál találkoztak, azok mondogatták, itt jönnák a csángösák [...] ”3

(Gábor, 2008)

The historical Moldova according to Benda is a region of $93.000 \mathrm{~km}^{2}$, having as borders, the river Szeret, the Lower Danube and the Black Sea. For almost a millennium it was a transit territory for riding - shepherd nations migrating from east, Asia to west. The Avars and some Bulgarian tribes followed the Huns, in the second half of the 800s the Hungarians, the Pechengs, the Uzes, and in the $11^{\text {th }}$ century the Cumanians. (Benda, 1989: 9) The habitants of Moldova changed over the years, some nations - Huns, Avars, Bulgarians and Hungarians - were just passing through this region, while others - Uz, Pechengs - remained or received shelter in Hungary. (Benda, 1989: 10)

Alexanru Zub wrote in 1991 that interpretations and definitions of Catholics from Moldova by outsiders is very diverse and often contradictory. The legitimate historical discourse, history used in a pragmatic way in valorizing the past, plays an important role in the development of this contradictory situation. (Zub in Cosa, 2007) Meanwhile Arens and Bein observes that the Csángó topic appears as an Eastern-European issue for many scientists from which it seems best to stay away. Non-Hungarian or nonRomanian scientists are somehow moderate regarding this topic - probably one writer is exception from this (Baker, 1997) - and somehow a deep ignorance can be observed.

(Arens \& Bein, 2004:112)

\footnotetext{
${ }^{3}$ Gábor, 2008:62-63The grandfather of my grandfather told him, that once upon a time happened that people turned away from God, and were prayingon knees for pagans. And God saw that His good people turned away from him, sent a great drought to them, and for seven years there was not a drop of rain, and it was such a hunger, that the good people went on a long way. They sold their houses, wealth to foreigners, and received in return horses, roes, goats to have milk for the children, and to pull the big tent carts. They put bells in the ears of the animals, so if someone gos to far, can find where the others are going, so they can always find eachother. If the calf or the goat runs away, the owner knew where to find them, because its ear rang as often as often moved. Since then we always put bells in their ears.

They went on long, long roads, to find their palce in the world. As they went, they were ringing than the entire road was ringing where they went. And if they met foreign nations, those said that here are coming those with bells. (Csengö=bell, Csángó=the group of people)
} 
The legtitimation of history, or legitimation by history, is nowhere more significant than in the origin debate whether Csángós are Romanian or Hungarians. Scientific literature mostly agrees on the Hungarian origin of Csángós. When speaking about the origin of Csángós, it is inevitable to speak about Romanians and Hungarians from Moldova, especially about their past. Romanians are known in Moldova since 1164 , "a group of people called Vlach" and in the $15^{\text {th }}$ century they were the majority in Moldova. Beside the Germans (Saxons from Transylvania) the largest minority in the central area of Moldova were the Hungarians. (Benda, 1989: 11) The first certified mention of Hungarians in Moldova is dated to the $13^{\text {th }}$ century. The first villages appeared on the right side of the Siret River, having the role of frontier guarding. Their habitants originated from the northern and southern - Szamos valley and respectively Szeklerland - regions as well. These Hungarians are called Csángós ${ }^{4}$ but their origin causes many debates in history. (Benda, 1989:12)

Pozsony Ferenc gives a good overview of theories concerning the origin of Csángós by grouping them in the following four categories. (Pozsony, 2002: 9-21) First group is composed by those theories that sustain that the Csángó community (or the major groups of them) is given by the descendants of those Hungarians who settled outside of the Carpathians in the $9^{\text {th }}$ century (theory sustained by ex. (Rubinyi, 1901), (Domokos, 1931), (Gunda, 1988)); the second approach states that Csángós are the descendents of some nations with a Turkish language (formulated by Hungarian theorists like (Jerney, 1851) and (Munkácsi, 1902) and by Romanian scientists as well like (Iorga, 1993)). Third, a group of scientists argues that the foundation of the Csángó community is given by those Szeklers/Hungarians who went to Moldova from the Carpathian basin starting with the $13^{\text {th }}-14^{\text {th }}$ centuries and a greater group in 1764 when the Massacre from Mádéfalva ${ }^{5}$ occurred. This theory sustained by (Benda, 1989), (Benkő, 1990), (Domokos, 1987), (Rosetti, 1905), (Lükő, 1936) and others as well, is the most widely accepted by the speacialized literature. While previous theory sustains the Hungarian origin of Csángós, the fourth group of theoreticians in Pozsony's typology is the one sustaining that the ancestors of Csángós are Romanians assimilated

\footnotetext{
${ }^{4}$ Benda, 1989:12: „A csángó szó ma ismert legrégibb előfordulása 1560-ból van. Az erdélyi Maksán említik csángó Andrást (Székely Oklevéltár. Szerkesztette Szabó Károly. V. Kolozsvár 1896.761) 1591ben egy moldvai adóösszeírásban is megtaláljuk a szót Tatros megye lakosaival kapcsolatban, „saigai” alakban, amit az irat kiadói sangai-nak értelmeztek (Hurmuzaki XI.219.1) A szó eredeti jelentését ,mai napig nem sikerült kielégítően megmagyarázni."

${ }^{5}$ In the Massacre from Mádéfalva (Mádéfalvi Veszedelem), under the rule of Maria Theresa, about 400 Széklers were massacred. The reason was, that they were not obeying the rule of the Habsburgs, and they resisted the forced military draft and organized a revolt.
} 
in Transylvania. This idea is mostly proposed by Dumitru Martinaş and although it rises serious controversy on its pertinence there are some scholars who sustain his theory.

The scientific interest toward Hungarians from Moldova aroused in the $18^{\text {th }}$ century and for more than a century focused only on their origin. (Benda, 1989:12) One of the first theories about the provenance of Csángós, states that they are the descendents of the Cumanians. Based on this theory the two nations are not only relatives, but their language is the same as well. The problem with this approach - as Benda shows - is that it is based on a false supposition, namely that the sibilant way of speaking that can be observed in some Csangó villages is not typical for Cumanians, Us, or Pechenegs either. Tampu in his handwriting calls our attention on two important things: one, that although Jerney János represents this approach, he observes a major thing, namely that among the Hungarians from Moldova there are two groups, one with szekler roots and one with older origin. (Jerney, 1851) Second, several works deny this approach, instead the Finno-Ugrian theory is getting more and more accepted, and this is sustained by Hungarian linguists as well. (Tampu, 2010: history thesis manuscript). At the beginning of the $20^{\text {th }}$ century there were still some authors claiming the Cumanian origin of the Csángós. Munkácsi for example was speaking about szeklerized Cumanians. (Munkácsi, 1902: 433-440)

The second theory argues that Hungarians from Moldova are the descendents of some Hungarian conquerors. (Le Calloc'H, 2005) Sustainers of this theory say that it can't be that all Hungarians left Etelköz, some groups - for example the older generation - remained along the rivers Szeret and Prut, and later other Hungarians from Transylvania and Hungary joined them. Benda calls our attention to the fact that even if this is not impossible, there are two problems, one that it can't be proved, second, that even by accepting the possibility of it, there is no evidence that Csángós are indeed the descendents of Hungarians from the $9^{\text {th }}$ century. (Benda, 1989: 13) There is one thing instead, that contradicts this theory: the way how these villages were named, is typical to the $13^{\text {th }}-14^{\text {th }}$ century instead of the Hungarian conquest. ${ }^{6}$

By the beginning of the $20^{\text {th }}$ century these theories faded, instead the one saying that Hungarians from Moldova migrated from the West, from the direction of

\footnotetext{
6 Benda Kálmán, 2003. 13.The names of these localities were created by using the -falva (village of...) or-városa, -vására (town of...) at the end of the name, which is typical for the 13-14 century, (Bogdánfalva, Szabófalva, Tamásfalva, Jászvásár etc),while in Hungarian and Transylvanian localities that can be originated from the conquest era another procedure can be seen, using personal names (eg, Álmosd, Solt, Tas)
} 
Transylvania gained credence. The only theory that goes against this accepted approach is the one elaborated by Dumitru Mărtinaş ${ }^{7}$ in his book The origin of the Csángós from Moldova $^{8}$. It was not a whole new theory, but since the 1980 s became the generally accepted approach by Romanian speaking scientists. Dumitru Mărtinaş is using the term of Ceangău - concept mostly used in Hungarian rather than Romanian language - but clarifies that he is doing so because of two reasons: by necessity, because it is established in the scientific literature and because there is no other appropriate word that could differentiate this population by others. (Mărtinaş, 1985)

The author approaches the topic of origin of Csángós, by quoting Dimitrie Cantemir: "tum natione, tum religione, ut se vocant Catholici" ${ }^{9}$ after which he makes an appeal to Mihail Kogălniceanu and the ad-hoc assembly of Moldova in 1857, where he defended the citizen rights of the Catholic communities. After presenting the earlier researches conducted mostly by Hungarian scientists, Mărtinaş sees the main problem of these studies in the fact that Hungarian scientists are so eager to prove the Hungarian origin of Csángós, that if there is no proof to that, they rather accept non-provable theories - refers to (Gegö, 1987), (Weigand, 1902) thought that Csángós have Cumanian origin, (Karácsonyi, 1914) sustained the Avar origins, others such as (Iorga, 1928) thought that Csángós have Pechengs origin, etc. - than to consider the most obvious possibility, namely that Csángós have Romanian origins, and the group that speaks Hungarian or a dialect of it, are actually Szeklerized Romanians from Transylvania. The attitude toward these scientific results is not just critical but condescending too. Mărtinaş tries to argue that all results achieved by Hungarian scientists should be questioned, or at least put under the shadow of doubt. The entire Csángó phenomenon is "enigmatic" as the author says. He - and his followers as well pay attention to a provoking investigation conducted by dr. Petru Râmneanţu biologist, who by analyzing blood samples proved that Csángós have the same patterns as Romanians and as such they have Romanian origin. ${ }^{10}$ Although this book was removed

\footnotetext{
${ }^{7}$ Dumitru Mărtinaş (1897- 1979) was a moldavian (Catholic) professor, who worked for several years in Transylvania, as a teacher in Arad, and later in Târgu-Mureş (Marosvásárhely). His scientific work contains some pedagogic essays and the work of „Originea ceangăilor din Moldova”, that he has been working on his entire life. http://www.asrocatolic.ro/profesor.html

${ }^{8}$ Dumitru Mărtinaş (1985): Originea ceangăilor din Moldova, Editura ştiinţifică şi enciclopedică, Bucureşti. The book was published with revision and comments by Ion Coja and Vasile M. Ungureanu after the authors death.

${ }^{9}$ By nation and by religion call themselves Catholics

${ }^{10}$ Mărtinaş refers to Petru Râmneanțu, Die Absammung der Tschangos, Sibiu, 1944, or in Romanian language Grupele de singe la ceangăii din Moldova, în „Buletin eugenic şi biopolitic”, XIV, 1943, nr 1-2, p. $51-56$
} 
from circulation - because some political circles didn't approve this solution - the article continues to appear in different publications, such as Catholic Almanacs.

The following section seeks to present the mentality and the evidence that lies behind the theory and the thesis formulated by Mărtinaş, who tries to prove the Romanian origin of Csángós. The key element of the theory is Szeklerization, a process through which Romanian individuals were assimilated to Szeklers in Transylvania. The author claims that in the $17^{\text {th }}$ century many Hungarian villages were attacked and destroyed by the Tatars and the Turks, some were even emptied and remained empty for a half century which led to a great population decline of the Catholic community. (The author does not wonder about how the population of Orthodox villages changed in the same period. Weren't Romanian or Orthodox villages also attacked?) The increase of population observed in the second half of the $18^{\text {th }}$ century is indeed - just as Hungarian theorists proved - the consequence of a migration process from Transylvania to Moldova, but migrants were - and here is where Mărtinaş disagrees with other theories - mostly szeklerized Romanians and finds proof to this theory in the language spoken by Csángós. (Mărtinaş, 1985:23) Being named by Orthodox Romanians as "unguri" "11 is simply due to their land of origin and to the process of szeklerization rather than their ethnic origin and identity. By referring to G. Popa- Lisseanu, Mărtinaş sustains his theory seeing in the decrease of Romanian communities proof of szeklerization: "Thus, between 1733 - 1760, in the counties of Udvarhely, Háromszék and Maros, Romanians, although less in number, were still present in 372 villages. After a century the demographic situation in these counties was like this: Romanians had disappeared completely in 119 villages and were almost disappeared in 123 villages. They managed to maintain only in 130 villages."12 (Mărtinaş, 1985:45) The author concludes that Romanians from the other 242 villages - or at least the majority of them - were integrated in the Szekler nation, but the rest migrated to Moldova. Among them are the Csángós as well.

The theory of Dumitru Mărtinaş can be best concluded, by using his own words, saying that after settleing in Moldova szeklerized Romanians quikly returned to their Romanian ethnic individuality. (Mărtinaş, 1985:46)

\footnotetext{
${ }^{11}$ unguri means Hungarians in Romanian language

12 Popa-Lisseanu by Mărtinaş 1985:45 „Avem însă date oficiale începînd cu sec. XVIII. Astfel, între anii 1733 - 1760, în județele Odorhei, Trei Scaune, Ciuc şi Mureş, românii, deşi scăzuţi ca număr, se mai mențineau încă în 372 de sate. După un secol, situația demografică în aceste județe se prezintă astfel: românii dispăruseră complet din 119 sate şi erau aproape dispăruți în 123 de sate. Ei au izbutit să se mențină numai în 130 de sate."
} 
To the question whether the new approach given by Dumitru Mărtinaş was trying to give a scientific base or background to the assimilation politics of the communist regime or it was a pure scientific research Arens and Bein answered that "Although even on the first sight one could recognize the gross propaganda paper that serves the nationalist Ceauşescu regime, yet this book shortly became the basis of today's Romanian view. [...] The theory of Mărtinaş remains unabated after the collapse of the Ceauşescu regime, and even spread. There is no doubt in the scientific community regarding the throughout dilettante nature of this work."13 (Arens \& Bein, 2004:114)

Although the work of Dumitru Mărtinaş is very divisive and as such, has many opponents - who proved that his theory is wrong or at least amateur - he has followers even today. One author needed to be mentioned is historian and museologist, Anton Coşa, the history advisor of the "Dumitru Mărtinaş" Roman-Catholic Association. At the beginning of his book (doctoral dissertation) entitled The Catholics from Moldova in the sources of Holly Chair (17-18 centuries) ${ }^{14}$ he refers to a „szekler” priest, Zöld Péter, who creates a false ethnonym - by using the concept of „Csángó-Hungarian” - and as such a "false ethnic problem in Moldova”.(Cosa, 2007) Coşa gives evidence that is familiar not only with Romanian but Hungarian studies and results too and sustains that using the term of "Csángó" for the Catholics from Moldova is unjustified, due to its usage over time with several meanings. Another problem with the concept is - as he continues - that the primary form of the term, which can be found in the Hungarian language like “csáng”, “csángani”, “csángódni”, “elcsángódni” shows a characteristic, a quality instead of ethnicity. ${ }^{15}$ (Cosa, 2007) A third problem is that it was always reported to one person, not a community, or not even the community that the person is from. Coşa agrees with Mărtinaş regarding the szeklerization of Romanians, which according to the author - "happened slowly, but continuously, in a peaceful and natural way. "16 (Cosa, 2007:29) There is agreement among the two authors in another aspect

\footnotetext{
13 Arens - Bein 2004: 114 „Bár első pillantásra felismerjük benne a nacionalista Ceauşescu-rendszer szolgálatában fogant otromba propagandairatot, ez a könyv mégis rövid időn belül a mai román álláspontok alapjává vált. [..] A Mărtinaş-elmélet töretlenül fennmaradt a Ceauşescu-rendszer összeomlása után, sőt még tovább terjedt. Tudományos körökben nem kétséges e munka egészében dilettáns volta.”

${ }_{15}^{14}$ Coşa (2007): catolicii din moldova în iyvoarele Sfântului Scaun(Secoalele XVII-XVIII) Sapientia, Iaşi

${ }^{15}$ Coşa 2007:27 „Noi am căutat această formă primară a termenului ,,ceangău” şi am găsit-o în maghiarul csáng, cu variantele csángani, csángódni, elcsángódni, cu întelesul de „străin”, ,îstrăinat”, arătând deci o însuşire, o calitate, fiind, cu alte cuvinte, un nume calitativ, şi nu unul etnic."

${ }^{16}$ Coşa 2007:29, ,Secuizarea românilor din sud-estul Transilvaniei s-a produs lent, dar continuu, pe cale paşnică şi naturală."
} 
too, the determinatives - "Hungarian" $" 17$ used to describe the Catholics from Moldova either by Orthodox, either by missionaries, were only showing their geographic and not ethnic origins. Similarly to Mărtinaş, Coşa also makes reference to Dimitrie Cantemir, and his observation about how Csángós define themselves as Catholics not only by religion but by nation as well. Coşa discusses the topic of origin by presenting both the Hungarian results and the Romanian ones as well. Although his sympathy fell on the side of the Romanian approach, and in many cases he seems quite subjective, he manages to show that not only in the scientific and/or national discourses, but on the consciousness level as well, the Catholics from Moldova are somehow in the middle, not entirely in any of the discourses, but being part of both of them. Coşa's approach about the origin, identity of Csángós and the way they are seen by others can be summarized by using his reference of Zub, saying that - and this is another point of convergence among Hungarian and Romanian scientists - the Csángó community not having intellectuals highly depend on the legitimating historical discourses coming from outside and this led to "a desired collective self-awareness and self-consciousness." 18 (Cosa, 2007:39)

There is another consensus point among Romanian and Hungarian scientists, who agree that based on the period when the community settled down in Moldova, Csángós can be grouped in different groups and not all have szekler origins.

As a conclusion it can be said, that the Romanian approach affirms that Csángós are Romanians, based on their origins, customs, language, wearing and specially their feelings, but they took part in a harsh process of szeklerization. They were named Hungarians, "unguri" by Moldavian habitants because they moved to Moldova from Transylvania, not because of their ethnic origin. The theory - although known as amateur by scientists - formulated during the communist era still manages to lead the Romanian mentality and especially public knowledge in Moldova.

A different approach can be observed in the Tişmăneanu-report. On the $18^{\text {th }}$ of December, 2006 the president of Romania, Traian Băsescu, spoke about the work and results of the Presidential Commission for the Analysis of Communist Dictatorship in Romania a 19-member commission, headed by Vladimir Tişmăneanu. The results are known as the Tişmăneanu-report, where the followings can be read regarding Csángós:

\footnotetext{
${ }^{17}$ In Romanian the conpcepts of „ungur” or „ungurean”

${ }^{18}$ Coşa 2007:39 “o dorită autocunoaştere colectivă şi la o conştiinţă de sine.”
} 
"The assimilation policy of the communist regime had dramatic consequences on the situation of Csángós from Moldova too, a community formed of about 60000 Hungarianspeaking people within Romano - Catholics in the counties of Neamt and Bacau. The first attempts of forced assimilation of Csángós dates from the interwar, with the Catholic Church assuming an important role in this process. Facilitating linguistic identity loss of Csángós allowed the Catholic Church to stop their assimilation into the Orthodox Church. ${ }^{19}$ Following these policies Csángós have not benefited from religious services and education in their mother tongue.

In the offensive against cults, $P M R^{20}$ took advantage of $U P M^{21}$, facilitating the establishment, starting with 1948 a network of almost 40 schools with teaching in Hungarian in regions inhabited by Csángós, they meant to weaken the Church's influence in the community. Schools were closed gradually during the period of 1953-1958.

In the 1970's and 1980's, in the context of accelerating the process of assimilation, those Csángós who declared themselves Hungarians were persecuted by police and security organs. "22 (Tismăneanu, 2006)

The president of Romania admitting the forced assimilation of Csángós - during the communist era - might be seen as a first step that could influence the Romanian scientific approach as well and it is also an acceptance of results attributed to Hungarian scientists only. A very detailed and thorough summary about theories concerning the origin of Csángós is given by Tampu Krisztián in his thesis. (Tampu, 2010)

Origin theories referring to the identity of Csángós occasionally only legitimize political, economic or other interests. Searching for an objective definition and identification, one can use the report of Mrs Tytti Isohookana-Asunmaa, presented to the council of Europe. Although it is important to mention that its acceptance also differs among Romanians and Hungarians. The rapporteur described Csángós as one of

\footnotetext{
19 Tişmăneanu-report referring to ANIC, fond Preşedinția Consiliului de Miniştrii - Serviciul Special de Informaţii, dosar nr. 63/1942, ff. 3-6.

${ }^{20}$ Romanian Worker's Party (Partidul Muncitoresc Român) (Román Munkáspárt)

${ }^{21}$ Hungarian Popular Union (Uniunea Populară Maghiară)(Magyar Népi Szövetség)

22 Tişmăneanu-report 2006:537 Politica de asimilare a regimului comunist a avut consecințe dramatice şi asupra situației ceangăilor din Moldova, comunitate formată din aproximativ 60000 de persoane cunoscătoare de limbă maghiară în cadrul romano-catolicilor din județele Neamț şi Bacău. Primele încercări de asimilare forțată a ceangăilor datează din perioada interbelică, Biserica Catolică asumându-şi un rol important în acest proces. Facilitarea pierderii identităţii lingvistice a ceangăilor i-a permis Bisericii Catolice oprirea asimilării acestora în Biserica Ortodoxă. Ca urmare a acestor politici, ceangăii nu au beneficiat de slujbe religioase şi educaţie în limba maternă.

În cadrul ofensivei împotriva cultelor, PMR s-a folosit de UPM, facilitând înființarea, începând cu 1948, a unei rețele de aproape 40 şcoli cu predare în limba maghiară în regiunile locuite de ceangăi, acestea având menirea să slăbească influența Bisericii în cadrul comunității. Şcolile au fost închise treptat în perioada 1953-1958.

În anii 1970-80, în contextul accelerării procesului de asimilare, ceangăii care s-au declarat maghiari au fost persecutaţi de organele de miliție şi de Securitate.
} 
the most enigmatic minorities in Europe, with uncertain origin and a strong Roman Catholic Faith. The size of the Csángó population is another topic regarding the csángós that has no accurate, well defined and widely accepted answer. The population size is ranging from 260.000 (the rough Catholic population of the region) to 1266 according to the census of 2002. Being segregated from other Hungarian speaking areas, results a very specific culture with Hungarian and Romanian elements as well regarding to which several proposals were formulated in order to preserve them.

“i. Parents living in Csángó settlements should be informed of the Romanian Law on Education and instructions should be issued on how to apply for its provisions concerning languages;

ii. The possibility of education in the mother tongue should be ensured in accordance with the Romanian Constitution. In the meantime teachers working on a voluntary basis in the villages teaching the Csángó language should be paid;

iii. There should be an option for Roman Catholic services in Csángó language in the churches in the Csángó villages;

iv. Csángó associations should be officially recognized and included in the list of the Council for National Minorities. Particular attention should be paid to the correct registration of the Csángó minority at the next official census;

v. Access to modern mass-media facilities should be promoted. Financial support should be given to Csángó associations to enable the issuing of a monthly publication and the functioning of a local radio station;

vi. Scholarships should be given with the aim of developing an intelligentsia among the Csángó people and securing work opportunities in the Csángó area;

vii. A local institute should be set up for the promotion of Csángó culture with a view to raising awareness of and respect for minorities;

viii. An information campaign should be launched in Romania concerning the value of the Csángó culture and the advantages of peaceful co-operation between the majority and the minorities;

ix. An international committee of experts should be established to study the Csángós;

$x$. The establishment of small and medium enterprises should be encouraged in Csángó villages." (Isohookana-Asunmaa, 2001)

The above mentioned report gives a valid insight on how the European Union perceives Csángós and their political, economic and cultural situation. Having an accurate estimation about the size of the minority is a necessity to which several tried to comply with. Different publications aimed to give a presentation and an estimation about the Catholics from Moldova and the size of the population, - just to name few (Bandinus, [1648] 1987), (Jerney, 1851), (Sebestyén, 1904), (Domokos, 1931) (Lükö, 2008)- but the comparison of these data sources is difficult, some give the number of households, others the absolute number of the population, the number of Catholics, or the number of Hungarian speakers, etc. (Tánczos, 2008:9) Supplementing with the 2002 
census data the distribution presented by (Tánczos, 2001), the following table can be made:

\begin{tabular}{l|rr} 
& \multicolumn{2}{|c}{$\mathbf{1 9 9 2}$} \\
\hline Catholics in Moldova & $\mathbf{2 0 0 2}$ \\
Bakó county & 243.133 & 243.708 \\
Neamt county & 125.805 & 119.618 \\
Iaşi county & 62.374 & 60.483 \\
Vaslui county & 39.627 & 40.396 \\
Vrancea county & & 6.607 \\
Galati county & 5.075 & 5.145 \\
Botosani county & 2.463 & 1.999 \\
Suceava county & 865 & 896 \\
& 9.542 & 8.564 \\
Gyimesbükk & & \\
\hline
\end{tabular}

Table 1: The Catholic community in Moldova according to the 1992 and 2002 census

Tánczos added to the table that while in the census of 1859 in Moldova $71.6 \%$ of Catholics were Hungarian, in 1930 the percentage was only 20,7\%, in 1992 only 1800 Hungarian Catholics are counted, which is only 0.7\%. (Tánczos, 2001) While the author (Tánczos, 1997) estimates the number of Csángós who still speak Hungarian to 62.265 and gives a region/locality level distribution of the population, in the 2002 official census only 1266 people declared themselves of Csángó ethnicity ${ }^{25}$.

\footnotetext{
${ }^{23}$ The number includes the locality of Ghimes Faget, which is part of Bacau county from 1960. While it's habitants are Csángós, they are Csángós from Gyimes - along with the habitants of Gyimesfelsőlok and Gyimesközéplok, localities of Hargita county - they are not Cángós from Moldova. In Gyimesbükk there were 3092 Catholics, 2933 Hungarians in 1992.

${ }^{24}$ At the last census, in 2002, the population of Ghimes faget had 5340 habitants from which 2522 were Romanian, 2720 Hungarians 71 Csángó, 25 Roma, and 2 of other ethnicity.

${ }^{25}$ It can be observed that in the case of communities that are considered as minoriatrian and especially if negative stereotypes, disparagement, shame, etc is associated to its members the accuracy of national census raises serious doubts. In some cases the number is over estimated, or less incorrect (like in the case of the roma minority, where the interviewer tends to write roma nationality even if the respondents tries to not assume it) while in other cases like in the case of Csángós, when the interviewer automatically selects the Romanian nationality - without being corrected by the respondent - decreasing the actual size of the csángó population.
} 


\subsection{Literature: Preliminaries of the investigation}

\section{Motto:}

"We may state what an elite is, but is much more difficult to find out who are the elites"

(Sereno, 1962:79)

A short review of the frame that sustains the subject helps in seeing more clearly the parameters of this research. The goal is to understand the procedure of elite development, to observe how a minority elite tries to find its place, wins validity in a majority society, to identify the channels of recognition, and to characterize their relationship among themselves and with the community they wish to represent. People thanks to their status or group position can have different positions in the society, positions which can have advantages or disadvantages, and in the same time through these positions they can connect with other actors of the society. Elite is the group that brings most advantages; being in elite positions means enjoying high prestige, being an active part of decision making, owning major wealth, having power, knowing people of high prestige, being respected by others, etc.

In order to understand processes through which elites reach these advantageous positions, several literatures came to my help. The theoretical approach is three folded on one hand elite theories and approaches, in addition approaches dealing with social network analysis (focusing first of all on social capital and social positions) and third concerning the (transnational) migration and its consequences. The theoretical approach sustaining the Csángó elite topic stands at the intersection of these theories.

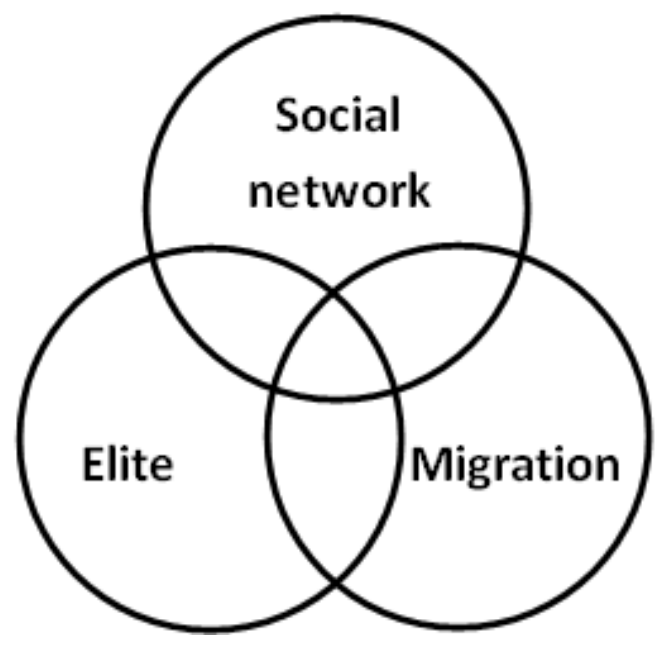

Figure 1: Theoretical approaches

The network approach in elite studies is and always has been of great significance. Well known authors in one way or another, always paid attention to the existence or the lack of connections between elite members. Mills (1956), Hunter (1959) or Guttsman 
(1963) all found that there is a strong connection between members, while Aron (1966), Parsons (1960), Dahl (1961), Rose (1967) found exactly the opposite, no connections or only purpose or function leaded linkages. It is important to acknowledge though, that network theories are much more a new approach with new data and new insights, than a new theoretical paradigm. Different approaches are usually bringing up new questions or new answers to old questions.

Classic elite definitions and identifications are often made based on power terms, but the difficulty of measuring power itself might induce problems. Mosca was the first who defined the concept of elite as those who take part in the political decision making, those who can manipulate the collective notions. (Mosca, 1939) Pareto considered the elite as the group of those who have the best abilities in a specific field, with tools of power at their disposition; stresses that elites can be acknowledged in their position inside a group or outside of it as well. The innovation of Pareto's elite definition was in seeing the elite embedded in the actual social progresses. (Pareto, 1963) Mills named those who have power in their hands, who are leading the masses as "power elite", seeing the tools of power in the state, enterprises and the army. Mills argues that elite can be understood as the inner circle of the "upper social classes". Speaking about ruling classes can't be done though without speaking about a network based on confident relations reserved through generations. (Mills, 1962: 16)

Different authors have different definitions of the elite. Elite was seen as a stratification category in a society, as a class, as a minority, as a group with power, etc. Ruling Class theory started with Marx to be followed by several generations after him. "The ideas of the ruling class are in every epoch the ruling ideas, i.e. the class which is the ruling material force of society, is at the same time its ruling intellectual force. The class which has the means of material production at its disposal, has control at the same time over the means of mental production, so that thereby, generally speaking, the ideas of those who lack the means of mental production are subject to it." (Marx \& Engels, 2004:64) The following generations interpreted elite definition and social stratification by reacting to Marx and Marxism. (Konrád \& Szelényi, 1979, King \& Szelényi, 2004, and several others). Wright stresses that even Weber, probably the most eager critique of Marx, uses his most Marxian voice when he talks about class. (Wright, 1996) Until the ruling class theory has been developed to its current form, there were always scientists who defended it (ex. Wright, Goldthorpe, Marshall, Brooks, etc.) by saying that class analysis "has as its central concern the study of relationships among 
class structures, class mobility, class-based inequalities, and class-based action” (Pakulski \& Waters, 1996: 670-671) and scientists who thought that class theory is inappropriate for the analysis of inequalities. (Nisbet, Pakulski, Waters, etc.) Pakulsky and Waters join this later group, referring to Nisbet, agree that while the concept of social class can be properly used in historical and in comparative sociology it is of no use in analyzing power, wealth or social status data in Western societies. (Nisbet, 1958 meeting of the ASA in Pakulski \& Waters, 1996: 667). Followers of the ruling class theory consider economic power the basis of political power; the ruling class changes from time to time, from regime to regime, but always has an economically well defined identity and as such owes its position through controlling the production of ideas and beliefs in society. There are two critical points in the ruling class theory, one is that reality seems over "simplified", it is hard to deal with the great increase in international inequality, and that it did not anticipate the development of government policies aiming to regulate the economy and avoiding crises. Bottomore gives a thorough and critical outline of the theoretical path leading from the ruling class to the power elite. (Bottomore, 1993 (1964)) Elite theories (ex. Higley \& Gunther, 1992, Etzioni-Halévy, 1997, etc.) consider the class that rules, "The first class, always the less numerous, performs all political functions, monopolizes power and enjoys the advantages that power brings" (Mosca, 1939:50) Elite definition confronts an ambiguity; it is not unequivocal whether the elites constitute a class or they are only the instruments, the spokesmen of a class. Higley, Burton and Field agree that the identification of elites is problematic, but these problems are smaller than those originating from competing concepts like "ruling class", "power networks", "the state". The authors agree with Marcus that "elite theory has the great advantage of being the only macrotheory in political sociology that operates on a "small-group, personal level of conceptualization," focusing on small numbers of people who can plausibly be viewed as sources of political continuity and change, who possess some important degree of internal organization, and who can often be described in considerable detail.". (Marcus, 1983 in Higley, Burton, \& Field, 1990: 422) In the plural elite model the leaders of all major sectors, fields, organizations and interest groups are present in the interaction network, domination of a single elite can't be observed and interaction inside of sectors is greater than among different sectors. Specialized, autonomous elites are competing with political elite groups. (Dahl, 1961, Rose, 1967, etc.). Behaviorist identification can be understood by referring to Lasswell for example, who saw in elites 
influentials. (Lasswell, 1936) The functionalist approach encounters two difficulties: one that is hard to agree on the functions of the political system, second difficulty comes from the fitting of "empirical data into the analytical categories". (Rustow, 1996: 696) Power elite theories sustain that it is a clear hierarchy of power and influence among different elite groups. Most important elite groups are business, political and perhaps military elites. The relation between the uppermost elites can be characterized with extensive positional overlaps, interlocks and interchanges, and frequent interaction. (Higley \& Moore, 1981: 585)

The short review of the specialized literature points out that the definition of elites can be very complex and different characteristics of the elite are considered important and decisive in the definition. As it concerns the method of identifying elites, it can be made in three ways: statistical, functional and structural. The first consists of the top $\mathrm{N}$ percent of a list made by ranking a specific capital. In the functional definition all outputs of relevant categories are listed. In this case the elite is composed of those who "have" caused more outputs. In the last definition researchers are using terms like group, role and status. As Kadushin says "Structural concepts are felt to be theoretically insufficient to define an elite, other concepts such as power or influence are usually added to the definition" (Kadushin, 1968: 689).

In the definition and identification of elites different capital theories can be used, capital types that go beyond the classic economic notion of the concept by applying the term to non-material forms as well. The concept of capital is used and interpreted on a wide range, regarding the investigation of the Csángó elite most important capital types are what Nan Lin calls Neo-Capitals first of all social capital.

But what exactly is social capital and how (if so) can it be measured? To understand the importance of social capital is useful to have the interpretation of human capital as well. First representatives of the human capital theory are Shultz and Becker, who saw another resource that can lead to profit. (Schultz, 1961, Becker, 1993 (1964)) According to this approach people consider human capital a good investment because the expected goods resulting from education are higher than the money and time they invest to achieve it.

Coleman dedicated high importance to the relationship among individuals, which he called social capital. Coleman considers that "social relations that constitute a form of social capital that provides information that facilitates action. The relations in this case are not valuable for the "credit slips" they provide in the form of obligations that 
one holds for others' performances or for the trustworthiness of the other party but merely for the information they provide." (Coleman, 1988:104) Shortly defined Coleman considers social capital "embodied in relations among persons". (Coleman, 1988:118) Mark Granovetter's article The Strength of Weak Ties pointed out how people weakly embedded are likely to link together, to transmit information among groups. As Granovetter calls attention "the analysis of processes in interpersonal networks provides the most fruitful micro-macro bridge. In one way or another, it is through these networks that small-scale interaction becomes translated into large-scale patterns, and that these, in turn, feed back into small groups." (Granovetter, 1973:1360) Beside Coleman and Granovetter there is another article often cited in this topic; the distinction among economic, cultural and social capital Bourdieu originally presented in “Ökonomisches Kapital, kulturelles Kapital, soziales Kapital”, later to be published in english as "The forms of capital". (Bourdieu, 1986). Bourdieu defines social capital as "the aggregate of the actual or potential resources which are linked to possession of a durable network of more or less institutionalized relationships of mutual acquaintance and recognition". (Bourdieu, 1986: 51) Bourdieu explains that it is a group membership which is beneficial to all members, yet the size, the volume of the social capital differs on the number of relations one can effectively mobilize. Another important observation discussed in the article is that capitals can be conversed, primarly by deriving from economic capital. In "Bowling Alone. The Collapse and Revival of American Community "26 Puttnam discusses the decline of social capital. Putnam differentiates two types of social capital - bridging and bonding - stressing two things: one that both can be beneficial and two that groups can have both type of social capital, bridging based on one dimension and bonding by another. Bonding or inclusive forms of social capital are "inward looking and tend to reinforce exclusive identities and homogeneous groups", while bridging relations are "outward looking and encompass people across diverse social cleavages." (Putnam, 2000:22) Fukuyama sees in social capital a factor that could explain specific characteristics of global economy, yet is relatively understudied. (Fukuyama, 1995) In a detailed lecture that can be accessed online, Fukuyama thorougly discusses the definitions, methods of measurement, origin and ways of getting more of it. Fukuyama defines social capital as "the existence of a certain set of informal values or norms shared among members of a group that permits cooperation among them" but

\footnotetext{
${ }^{26}$ is a book-length discussion of the Bowling Alone: America's Declining Social Capital, article published 5 years earlier (Putnam, 1995)
} 
explains that simply sharing these norms does not produce social capital, due to the possibility of having wrong values. (Fukuyama, 1997:378) In order to produce social capital, norms should include positive characteristics that "overlap to a significant degree with those Puritan values that Max Weber found critical to the development of Western capitalism." (Fukuyama, 1997:379)

Ronald S Burt starts his article about structural holes by explaining the social capital metaphor, as nothing but those people who are better connected than others, those who by having a certain position in the structure of exchanges can use their connections as useful, rightful assets. (Burt, 2001:202)

Nan Lin joins together social capital and social network analysis by considering social network the best way for social capital measurement. Defines social capital as "resources embedded in a social structure which are accessed and/or mobilized in purposive actions. By this definition, the notion of social capital contains three ingredients: resources embedded in a social structure; accessibility to such social resources by individuals; and use or mobilization of such social resources by individuals in purposive actions. Thus conceived, social capital contains three elements intersecting structure and action: the structural (embeddedness), opportunity (accessibility) and action-oriented (use) aspects. " (Lin, 1999:35)

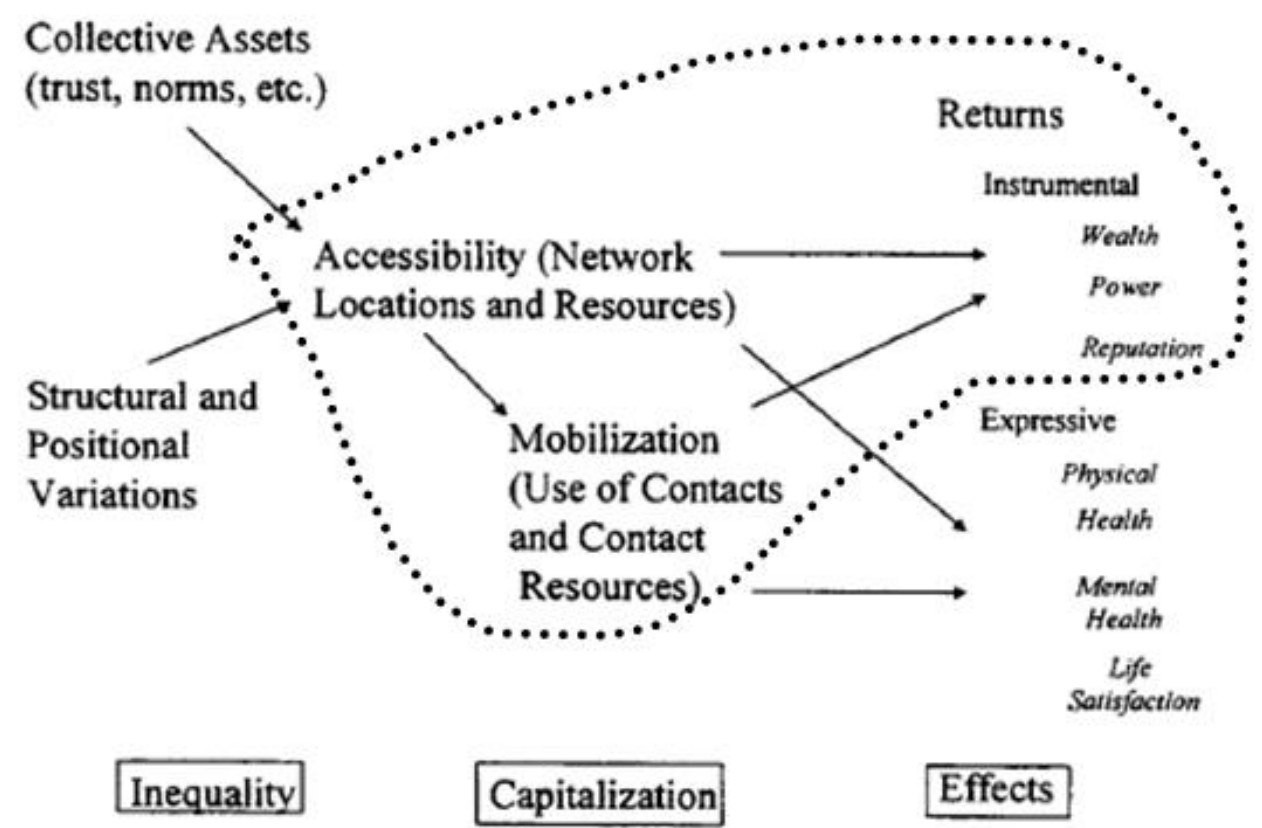

Figure 2: Modeling a Theory of Social Capital. (Lin, 1999:41)

The process of capitalization depends on two ways: access to social capital and use of social capital. Social capital mobilization is the process that connects access with use. Lin explains the model in one question: "given the unequal distributions of social 
capital how would an individual be enabled or disabled to mobilize such capital for specific actions?" answering that "while recognizing structural contributions to social capital, as captured in the inequality process, also emphasizes possible choice action in mobilization." (Lin, 1999:41) The third block shows the returns of social capital, the link between block 2 and 3 stands for the processes in which social capital influences someones life.

Using the model drawn by Lin the topic of the Csángó elite stands in the transformation of Accessibility and Mobilization into Instrumental Returns (Wealth, Power, Reputation), visualized with dashed line.

Following Lin in defining social capital as some sort of resources embedded in social structures that can be used in purposive action instead of bringing answers raises more questions. How is the application of social capital theories helping in the identification of elites? And how can the number of relations one has explain his/her social capital?

The importance of social relations and interactions and their investigation in order to understand one's behavior goes back to Freud's psychoanalysis. While psychologists were trying to heal individuals whose relational data they have collected, social network analysis seeks to present and to understand social structures and phenomena. Taking the widest definition social network analysis is the investigation of relationships (and their patterns) among different social actors (individuals, organizations, countries, etc.). One of the first representatives and founders of the network approach was Jacob Moreno and his Who shall survive ${ }^{27}$ titled book discussing sociometry. (Moreno, 1953 (1934)) In 1954 J. A. Barnes introduced the social network concept.(Barnes, 1954)

Some authors argue that material capital and power as such is not the most important, but the emerging and critical form is the human capital. "The centrality of cultural capital in Bourdieu's analysis of organizations, of skill/credential assets in Wright's analysis, and of occupational/skill bases of stratification in Goldthorpe's analysis each reflect this shift". (Pakulski \& Waters, 1996: 673) Power is a disposition concept, so using an open- ended network rather than a sociometric of a closed group might bring more results. As Kadushin points out "Methods for measuring social circles require open-ended sociometric chains, such as "snowball” samples, although

\footnotetext{
${ }^{27}$ In this book Moreno calls attention on two important prior dates, the 1933 Medical Society of the State of New York exhibition of medical sociometries, and second that even prior to that in his 1923 published Das Steigreiftheater titled book already contained "the seeds of many of the ideas which later brough sociometry to fame"
} 
there are also useful pseudo-interaction methods." (Kadushin, 1968: 685) The connection of network members can be direct, face-to-face or through other connections, through chains of interactions, as in social circles. (Kadushin, 1968, Alba \& Moore, 1978). In the definition of the elite I rely highly on the "social circle" approach introduced by Kadushin. (Kadushin, 1968) Theoreticians seem to agree that elite social circles are a principle means of elite integration. Due to their two dice communication can connect, communicate and interact with large numbers of individuals who are not necessarily geographically in the same place, who are located in otherwise disparate organizations and sectors. To the question what do we understand by social/elite circles, Kadushin answers that a social circle "may have a chain or network of indirect interaction such that most members are connected at least through a third party" which exist because of the common interests shared by the members. (Kadushin, 1968: 692) The circle should not be seen as a formal institution, the common interest brings together its members and even though there might be central figures there are no clear, formal and/or elected leaders. Membership is not granted based on some distinct criteria and interaction is not defined by rules. Kadushin differentiates cultural, utilitarian, power and influence, and integrative interests, shared by members of social circles. (Kadushin, 1968: 692).

By now it is clear that social capital can refer to individuals and to groups as well, just as it is clear that relations can be investigated among group members and among members of different groups. To the question of how social capital can be measured a good answer is that by social network analysis, by finding out how embedded is someone in the social structure surrounding him/her and also by researching his or her position, role and influence in that structure.

As it concerns the topic and the level of interest (and technical approach as well) Social Network Analysis (SNA) has two major fronts: one is the so called "whole network analysis" which focuses on a well defined group of actors and investigates relational patterns among the members of that specific group, second is the Egocentric network, which studies the relations of an Ego, of one person. This second type of SNA can be also differentiated whether the number of the alters (persons related to the Ego) are limited to members of a group or not. In the illustration below, N1 is the whole network of an office for example where John works, N2 is John's Ego-network, including only those coworkers with whom John is directly connected (ex. they are 
working on one project), N3 is John personal network, yet he will not be present in N3, only his alter and the relations among them.

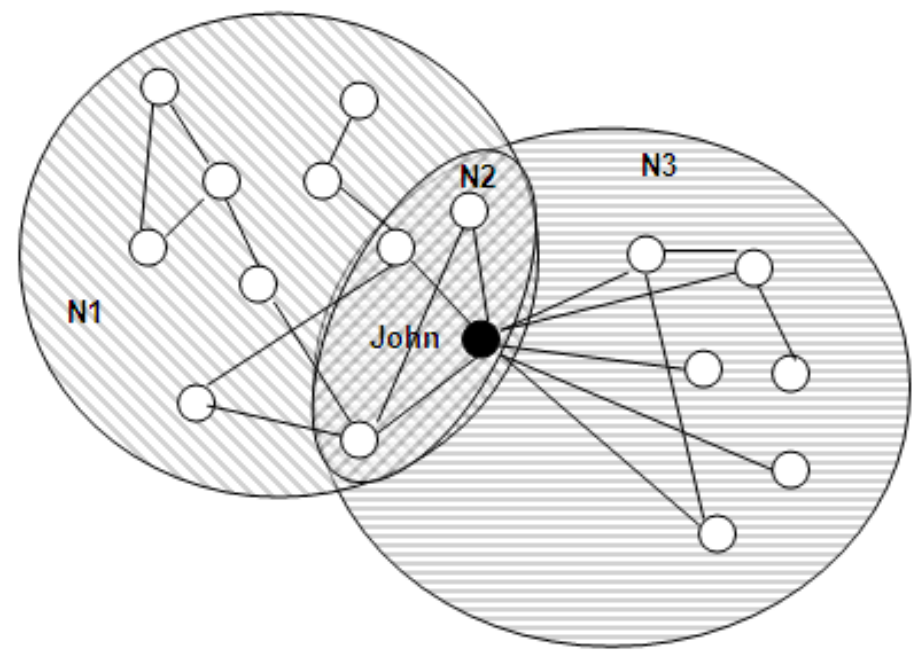

Figure 3: N1 total network, N2: ego-network, N3: personal network

It is important to mention that this differentiation between ego-networks and personal network is not followed by all conducting SNA. Personal network data gathering and analysis can be done similarly to questionnairing, relational data being collected from a representative sample, data can be analysed statistically, etc. Molina and McCarthy are some of those who use this approach and strictly distinguish personal networks from ego-networks. (For articles focusing on personal newtorks see for ex. Lubbers, et al., 2007 or McCarty, et al., 2007, who collected relational data refering ones personal network through questionnaires and structured interviews.)

The beginning of the SNA leads back to the structural-functional theories of A.R. Radcliffe-Brown who emphasized the idea that society is the system of social relations. (Radcliffe-Brown, 1940) The first scientist who applied this approach was Max Gluckman, who not only stressed that during fieldwork data referring to interactions should be collected too, but when in 1947 he became the leader of the social anthropology department at the Manchester University; he established what is known today as the Manchester School. Gluckman organized seminars to bring together well known anthropologists, who had a great role in propagating the network approach. (ex. John Arundel Barnes, Elizabeth Bott and Clyde Mitchell, today recognized as being the pioneers in systematic personal network analysis and data collection. Barnes determined the personal ties that link together the formal structures of a village and was the first to use the concept of (social) network, saying that earlier he opted for the concept of web "However it seems that many people think of a web as something like a spider's web, in 
two dimensions, whereas I am trying to form an image for a multi-dimensional concept." (Barnes, 1954) Barnes notes that when he moved to the London School of Economics he found that Elizabeth Bott was working with a similar approach in her investigation on married couples. Bernes remembers that „Neither her findings nor mine attracted much attention at the time." (Barnes, 1987) Bott's kinship investigation was different in one aspect though, she was not aiming to present how a society works, rather how one institution of the society functions. Bott recognized that networks are not the same, and different types of networks can be observed: "there was considerable variation in the 'connectedness' of their networks." They introduced the 'close-knit' and 'loose knit' concepts, in order to characterize whether there are many or few connections among component units. (Bott, 1957: 59)

Barry Wellman firstly names Clyde Mitchell as the elder of network analysts, with a pioneering integrative edited book. (Wellman, 2000) Clyde Mitchell identifies three orders of social relationships that serve the interpretation of one's behavior. The structural order interprets behavior "terms of action appropriate to the position they occupy in an ordered set of positions", while the categorical order stands for the unstructured situations, it can be explained in stereotypes and finally by the means of the personal order behavior is interpreted "in terms of the personal links individuals have with a set of people and the links these people in turn have among themselves and with others, such as the social networks" (Mitchell, 1969: 9-10) Mitchell also distinguishes total networks and personal or ego-centered networks.

“A 'total network' may be described as a set of elements (people) and a set of relations (links) in which the set of people may or may not be finite and the set of links may or may not be finite. [...] A 'personal network' is a sub-set of total network, the sub-set having a finite number of persons and associated links. The sub-set is termed an 'ego-centred' or 'personal' network if it has the property that an ego has a 'pole position' in the sub-set so that all other persons and their links are ordered with reference to this 'pole position'."(Mitchell, 1969: 301)

Also introduced concepts like: link, clique, commune, etc. concept that are still used and central in SNA investigations.

The network approach was encompassed by researchers in the US as well, especially the University of Chicago and Harvard. One of the most influential articles in social network analysis is the one - already mentioned - written by Mark Granovetter referring the strength of weak ties. The research base was the mapping of the variety of 
job searching methods through personal networks. The results showed that information was often transmitted through personal relations, through individuals the respondent knew. The surprise of the results was standing in the fact that these opportunities did not came from the closest relatives, from people the respondent knew well, rather from acquaintances. (Granovetter, 1973) Another famous result is given by Stanley Milgram, who proved that the average number of connections among randomly chosen two Americans is between five and six. (Milgram, 1967)

The micro-macro division and interoperability among ego-networks and whole networks can be used - as it was firstly done by Charles Kadushin - to construct the relations among members of hidden communities or groups that are hard to define. The key concept used by Kadushin was the term of "social circles". Using personal networks combined with snowball sampling Kadushin managed to describe the social circle of the French financial elite (Kadushin, 1995) and prior the social circle of friends and supporters of psychotherapy. (Kadushin, 1966)

Personal network analysis is effectively used in investigations concerning health issues. Tom Valente and colleagues used the method to demonstrate that friendship ties were associated to contraceptive method choices, (Valente, et al., 1997), Latkin and colleagues - using diffusion analysis - explained the relation among personal network characteristics and needle-sharing and transmission of HIV. (Latkin, et al., 1996) The density of the personal network proved to be directly proportional with the odds of sharing needles.

Personal network characteristics can be used to measure social support that one individual has, regardless if it is referring to migrants, ill people (ex. drug use, alcoholism, psychiatric disease, sexually transmitted disease etc.)

The social network approach is present in investigations concerning the diffusion of innovations as well. The spread of innovations - according to Valente - depends on network characteristics. (Valente, 1995) The question what makes some people to adopt and implement new ideas - innovations - while others are indifferent, or react much later is not an innovation itself. The pioneer work dates back to 1943, when Ryan and Gross demonstrated the importance of social factors in the implementing process. (Ryan \& Gross, 1943) The question can be found in several scientific fields such as economics, marketing, anthropology, epidemiology, etc. (ex. Brown, 1981, Bailey, 1975, Morris, 1993; Rogers, 2003) In the 1950's - 1960's several studies were conducted in the topic of diffusion of innovations. (For details see Rogers, 2003) One of 
the most often cited works refers to the spread of tetracycline. (Coleman, et al., 1966) In the last two decades of the previous century several new articles and results came to light many of them concerning mostly methodological "experimentations" in the intersection of network properties and diffusion. (For a review see Valente, 1995)

Valente draws attention that because of the difficulty - long enough time to diffusion occur in an entire network - several studies used retrospective data while others relied on two investigations "that collected network and adoption data". (Valente, 1995: 105) Valente names two studies that were often reanalyzed, first is the already cited Coleman, Katz and Menzel tatracycline investigation (Coleman, et al., 1966), the other was conducted by Rogers and Kincaid referring to how Korean women organize themselves and their families. (Rogers \& Kincaid, 1981) Diffusion investigation can be done in egocentric approach as well, and as such the difficulty named above is avoided, Marsden for example used the network data collected with the 1985 General Social Survey. (Marsden, 1987)

With the computer aid network analysis the investigation of diffusion became easier and new investigations and results show up. While the diffusion investigation is present in social, economic and health concerning researches as well, and while network approach gives many answers (and draws even more questions) it cannot be seen as an alternative explanation to the spread of innovations. As Letenyei explains instead of seeing it as an alternative explanation it should be seen rather a supplement of the traditional economic approach that emphasizes the role of comparative advantages. (Letenyei, 2002)

Computer facilitated SNA turned the attention of investigators to the analysis of network structure and to the interpretation of roles and positions in social network, such as opinion leaders and brokers. Network density is often used to present the social structure of a group. Although high density might reduce innovation, because having many connections it is likely that members will also share a common vision of the world, and very similar values which would inhibit the spread of new information, new ideas not against, but due to the very dense interconnection of members.(Grabher \& Stark, 1997)

Burt considers that brokers are able to take advantage from Structural holes, by transmitting information between otherwise not connected people or groups. Burt sees the advantage of brokers in "information access and control; networks that span structural holes provide broad and early access to, and entrepreneurial control over, 
information." (Burt, 2002:248) The advantage of bridging together actors that are at the two sides of structural holes already appeared in the weak ties (Granovetter, 1973) or in betweenness centrality (Freeman, 1977) which measures how much an actor "brokers indirect connection between all other people in the network" (Burt, 2001:209)

Obstfeld focused on microprocesses in organization innovation networks, naming broker as "tertius iudens" (third who joins). Considers "The language of structural holes theory is often a language of competition, control, relative advantage, and manipulation. (Obstfeld, 2005:120) The tertius iudens is in advantageous position by driving collaborative actions. More than 50 years earlier Simmel wrote about tertius gaudens who unlike the tertius iuden maintained his/her advantageous position by keeping the distance among linked actors. Obstfeld considers that "Structural holes theory develops the particulars of tertius gaudens dynamics in a conception of social organization built around competition and stressing a set of dependent variables that are outcomes of those com- petitions (e.g., promotions and profit)." (Obstfeld, 2005:120)

Fernandez-Gould differentiated five Brokerage types based on group membership of the sender, the broker and the recipient. In the table below the information flow is from 1 to 3 by passing through 2, who is the broker. (Fernandez \& Gould, 1999)

\begin{tabular}{l|l|l|l|l|}
$\begin{array}{l}\text { Coordinator: } \\
\text { Gatekeeper: }\end{array}$ & $\begin{array}{l}\text { Representative: } \\
\text { A->A->A }->\mathrm{A}\end{array}$ & $\begin{array}{l}\text { Consultant: } \\
\mathrm{B}->\mathrm{A}->\mathrm{B}\end{array}$ \\
\hline $\begin{array}{l}\text { all nodes } \\
\text { belong to same } \\
\text { group }\end{array}$ & $\begin{array}{l}\text { source belongs different } \\
\text { to }\end{array}$ & $\begin{array}{l}\text { group } \\
\text { recipient } \\
\text { belongs to } \\
\text { different group }\end{array}$ & $\begin{array}{l}\text { broker belongs different } \\
\text { group }\end{array}$ & $\begin{array}{l}\text { all } \\
\text { belong to } \\
\text { different } \\
\text { groups }\end{array}$ \\
\hline
\end{tabular}

Legend: Osame group, $\bullet$ different group

Fernandez and Gould find that converting network position into power is contingent on two things whether the actor is a government organization and on the type of brokerage.(Fernandez \& Gould, 1999)

Katz found that there is a great similarity among opinion leaders and those they influence, and influential and influenced can exchange roles on different occasions. (Katz, 1957) Identifying opinion leaders can be done in three ways, by self-nomination, 
by sociometric techniques and key informant technique. (Rogers \& Cartano, 1962) Iyengar, Van den Blunte and Valente find among others that sociometric and self reported measures are in poor association and there is a chance that they capture different constructs (Iyengar, et al., 2011). Katz and Mensel consider that instead of dealing with a "two-step flow of communication" (Katz \& Lazarsfeld, 1955) rather a multi step interpretation should be used stressing that several other sources could channel influence from opinion leaders to others. (Menzel \& Katz, 1955-1956)

There is one common characteristic in opinion leaders and opinion brokers, namely they are those actors in a network who are bridging together two sides of the structural hole, gaining influence and power over members of the network. This bypass on the topic of opinion leaders and brokers was aiming to give another theoretical approach that can be used in the identification of the csángó elite. Little has been said about elite investigation, since classical elites sociology cannot be used, or not efficiently in the case of Csángós. Although elite investigations are mostly conducted by sociologists and historians the anthropological approach, focusing on traditional societies might be closer in identifying Csángó elites. Anthropology used a different approach and understood different things under 'elites' than sociology; probably is closest to the prestige based elite definitions.

In the concern of anthropology it wasn't the power of actors, or the classes of a society in the sociological terms, rather how the members of the elite operate, are related to the community, are defining culture, etc. As Shore enumerates several anthropological investigations can bring new insights to the elite topic as well, research focusing on "political organization, oratory and power, social stratification, ritual and leadership, networks or kinship and ethnicity” (Shore \& Nugent, 2002:10) For anthropologists it is important to see the elite as a group, instead of elite members, as separate actors of a society, or a social class. Kinship, friendship, rituals, behaviour are only some of the informal dimensions of elite organizations that are of major interest for anthropologists. (Shore \& Nugent, 2002:11)

As it concerns the anthropological approach there are several methodological aspects to consider. It is important to acknowledge that elites are educated people who are not only capable to represent themselves but they indeed often do so, are present in the public knowledge not only by being known but by being able to speak, to write, to represent and to act in their own interests. It is this that makes elite investigation or studying-up difficult. Studying-up, investigating elites is not a typical anthropology 
topic. Laura Nader urged anthropologists in 1972 to turn their attention to these actors of the society yet at the same time she explained why there are so few elite anthropology investigations: "anthropologists value studying what they like and liking what they study and, in general, we prefer the underdog. " (Nader, 1972:203)

Shore and Nugent in their edited "Elite cultures: anthropological perspectives" titled book bring together different investigations of elites from all over the world, in order to answer how can anthropology contribute to the understanting of elites, how they operate, define, maintain and sustain their identity, status and prestige. Referring to Laura Nader's demand in her review about Shore and Nugent's edited book Stefanie Lotter says that "it is reasonable to say that we have waited thirty years for the publication of the edited volume." (Lotter, 2004)

Chris Shore in the introduction of the Elite cultures sustains that every society has its elites, as the author names them the "priviledged minorities" who can be privileged due to "reasons of history, social status, economic position, political office or family connections". (Shore \& Nugent, 2002:2) Referring to Herzfeld the introduction of the book sustains that the accurate investigation of elites is the researching of the "habitus, networks and culture of elites themselves, including their informal and everyday practices and intimate spaces.” (Herzfeld, 2000 in Shore \& Nugent, 2002:6)

Abner Cohen draws attention on the problem faced by elites, to attune universalism and particularism. (Cohen, 1981)It is an important question to answer whether it matters for elites to recognize as such themselves or it matters more to be seen as elites by others. Marcus considers the concept of elite, a "term of reference rather than a self-reference". (Marcus, 1983:9)

How to achieve the level of confidence, the intimacy that makes possible to study these people and these groups in order to gain information that is not spoken or not acknowledged by them (Herzfeld, 2000:230), due to the lack of specialized knowledge, because they see everything - obviously - with the eyes of insiders, while the researcher can step back and have a wider look. Accessible and effective elites can be differentiated and later investigations were presenting to the previous group (see chapters of (Shore \& Nugent, 2002) such as the one referring to the English Catholic elite by J. Eade, or the one about mestizo traders in Peru researched by P. Harvey, etc.)

Shore suggests four fronts on which elites should be anthropologically studied: in historical context (considering wider economic and social aspects) dynamically instead 
as static entity, in reproducing, recruitment strategies and finally by investigating on the legitimizing techniques they use. (Shore \& Nugent, 2002:13)

In her study referring to elite transformation in Nepal, Stefanie Lotter defined as elites not only those who would be seen as such on the international level, but those too, who outside of Nepal would be defined - based on their living standard - as middle class. The author points out that qualitative data collection has a deficiency as well, especially when it applies to effective elites. The interview situation usually involving only the interviewer and the interviewee is slightly changed when as the author describes it: "The comfortable interview situation, where one sinks into a large sofa, a glass of wine in hand and sandwiches decorated on a silver platter to one side, may be an unusual working atmosphere for an anthropologist and one should not be deceived by what appears to be acceptance and familiarity. The gatekeepers of the elites are still present and the anthropologist is expected to leave after the two hour-long interview is finished and should have the decency not to return." (Lotter, 2004) Doing fieldwork among elites is a constant negotiation and adjustment of researchers regarding their position in the field, and these changes aren't always intended, conscious and planned strategies, or individual choices. (Fumanti, 2004)

As interesting as interviewing is, it doesn't make possible to observe elites in their social circles. As Fumanti introduces "The making of the fieldworker: debating agency in elites research" titled methodological article, elites regardless of their "profile" have a central, key position in the community, and is this prominent position that separates them from the rest. Attitudes toward elites is dual, on the one hand it brings them prestige, high status, recognition and privileges, on the other hand their acts are always followed and often questioned and criticized, their deeds are accompanied with suspicion. (Fumanti, 2004)

Harvey draws attention on one inaccuracy or maybe drawback of anthropological elite investigation, more precisely participant observation, it tends to over-locate the topic. The method anticipates the identification of local elites, and as useful as these results are "we might be more inclined to think of 'elites' as those who are best able to avoid the constraints of location and who no longer need the grounded legitimacy that my Ocongate traders sought." (Harvey, 2002:74) According to Harvey elites are enrolled in a "Janus-type existence", meaning that elites "both to 'modernise' their immediate environment, surrounding themselves with powerful symbols of distinction to mitigate the effects of their rural attachments, while at the same time bolstering these 
attachments primarily through recourse to a gendered division of symbolic labour - in order to maximise local trust and acceptability." (Harvey, 2002:84)

Konrad thinks that anthropological investigation of elite cultures before anything faces the problem of terms that might be used by researchers to present the power relations in topic. (Konrad, 2002) when it comes to discussing nationalism especially in socio-political context, national elites are usually brought into focus. (Spencer, 2002)

Nugent sees the difficulty of Amazonian elite investigation in the fact of not having a generic Amazonian society. Approaching structurally a society that is - as Nugent best describes - a mosaic, that is "socially amorphous and naturally rigid" even if not impossible, than the least to say is of high challenge. Historical background shows no previous - pre-modern - Amazonian elites that have continuity in current elite configurations, yet the author admits that the role of elites is an important question in the case of indigenous societies as well. (Nugent, 2002:63) The article has an important observation - especially as it concerns the Csángó elite - by saying that "if one is looking for Amazonian elites, one could do worse than look outside Amazonia." (Nugent, 2002:68)

This last sentence of finding elites of a region in another region leads to the third theoretical pillar of the investigation, namely transnational migration and its consequences. In several East-European countries after the regime change a proportional growth of the urban-rural migration was observed (in Romania between 1990 and 1998 migration grew from 3,5\%, to 28,4\%), the root cause was urban unemployment - failure of heavy industry, the bankruptcy of factories or cut-backs of personnel - and the ,easier” rural life-style insured by agriculture. The problem was the limited capacity of reception and support of this voluminous population excess and because of this for the young generation the international work opportunities were the only chance to outbreak. The regime change was followed by a proportional growth of working abroad ${ }^{28}$, Massey saw this period as the time when so far segregated Eastern countries of Europe met the capitalist West. (Massey, 1998) Nowadays is a general view that „without foreign guest working it is hard to get a start” (Csángó guest worker) „,Transnational migration is a relatively new phenomenon, associated with globalization processes and with the development rationale of contemporary capitalism.’(Sandu, 2005 refers to Portes, 1996, 1997)

\footnotetext{
${ }^{28}$ See the table in the Annexes for a detailed presentation of Romanian migration patterns over the years.
} 
In 2001 Dumitru Sandu conducted a national level investigation concerning the migration from rural areas and drew a map ${ }^{29}$ of the main regions of external circular migration. Sandu observes that circular/transnational migration is strongly influenced by religion and as such migrants from Moldova are migrating first of all to Italy. Romania was divided in 15 migration regions with specific identity shaped, - not only by migration profiles but also - socio-demographic characteristics. Moldova is characterized as the "youngest flow of migrants" in Romania. (Sandu, 2005:564) The region of Moldova with csángó communities beside Italy migrates to Hungary and Turkey, while other moldavian counties (the northeastern part, Iasi, Botosani and Suceava) are attracted to Israel as a secondary goal country.

Consequences of migration can be social, legal, cultural or political, depending in which sphere can the change be seen as a follower of cultural variegation. Given the character they can't be easily measured, but it can be said that the primary impact is undoubtedly that the receiving society is diversified, culturally heterogeneous. The receiving countries have to face the fact that several migrants (short term migrant like guest workers) will turn into long term migrants later to gain citizenship. The majority of the receiving countries can respond to the challenges of migration, there are laws protecting minorities, laws that stand for the rights of migrants, even though the receiving society often reject or dismiss them.

Migration investigation has a long tradition in Hungary as well. Several works seek to answer the reasons of migration, why some people opt to leave focusing on the socio-demographic characteristics of the migrants. (Sik, 1989, Tóth, 2003, etc.) Dövényi presented the territorial, regional distribution of migrants living in Hungary (Dövényi, 1997) while others were interested in legal and political conditions and consequences, etc. A great majority of migrants in Hungary is formed by Hungarians from neighbouring countries. Scientific interest toward these migrants can be found in the receiving country and out-migrating country as well. (for example Gödri, 2004, Horváth, 2002, Bíró, 2002, etc.)

Different communication channels, participation to economic, politic or simply the regular travels make possible for the migrant to be present both in the home-land and the receiving land. Short and long time migration to close and further away distances are influencing the out-migrating community, shaping the structure of that society and forming everyday life.

\footnotetext{
${ }^{29}$ The map can e seen in the Anexes
} 


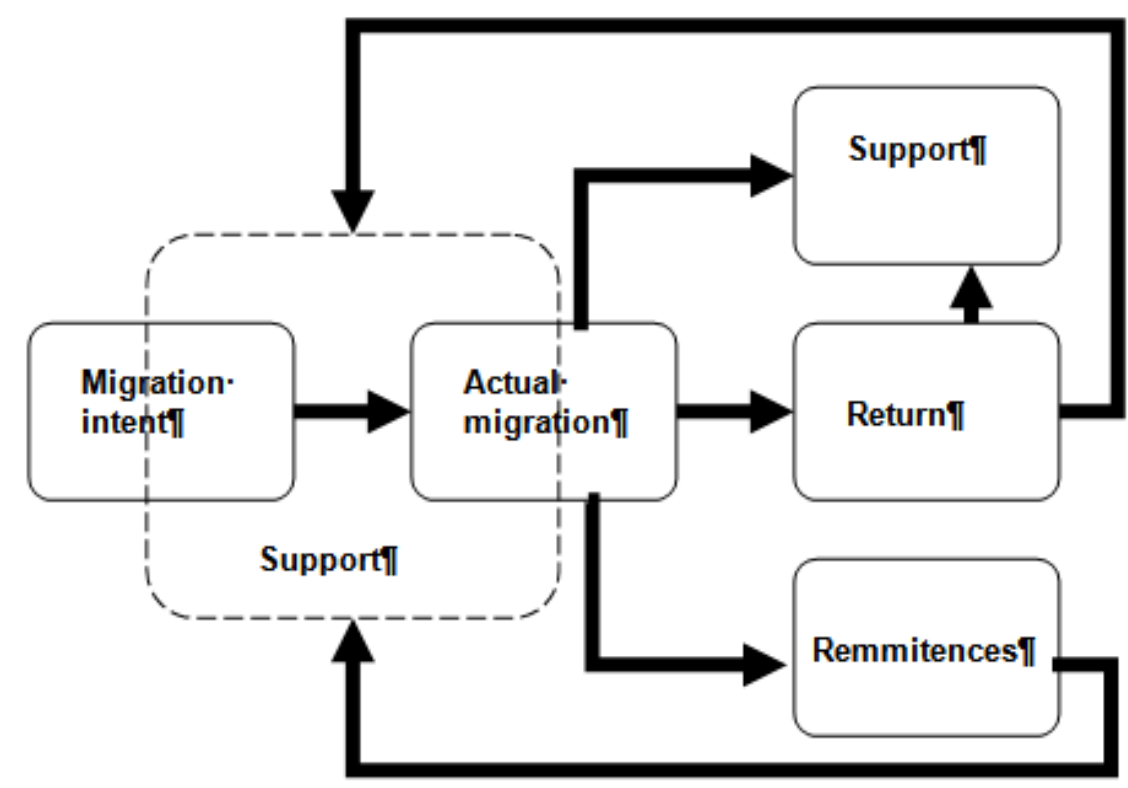

Figure 4: Visualization of the migration process among Csángós

Researchers and publications can be enrolled mainly in two groups; some scientists seek to find out the reasons, others the consequences and outcomes of migration. Based on the reasons of moving, migration types can be differentiated with subjects having different status (guest-workers, refugees, student mobility, business mobility etc., with another approach we can distinguish forced-, periodic- migrations, emigration, etc.). Often when analyzing migrations the focus turns to the study of migration potential through soft variables (attitudes, subjective intents, identity and the effects of migration on the identity of migrants, relations among ethnicities, etc.), as Csata and Kiss points out in examples referring to Transylvania there is a strong relation among convertible capitals and ethnicity. (Csata \& Kiss, 2003/2)

Migration processes can have intended and unintended outcomes as well, both shaping the out-migrating society. Consequences that by differentiating short and long time outcomes should be taken in consideration in the case of the Csángó elite as well.

Dissecting the migration process, three differentiated phases can be observed, first is the disturbance in the ecosystem, and its regional or sectoral effects. The first phase has two types, depending if is characterized by push or pull factors. The second step is the geographical mobility. Finally, the "stabilization", the attitude toward migrants and the relational process between migrants and the receiving location. (Adler-Lomnitz, 1975: 29) For these three phases specific territories like homeland and the land of work and if the travel is institutionalized, the two territories connected by an organized and more or less regular traveling results a third territory can be assigned. The group 
involved in the regular traveling can be described with a dense relational network. Those enterprises which in a formal and institutionalized way take advantage from "guest working", can be seen as establishers of a new industry. (Gagyi \& Oláh, 1997) According to J.T. Romans the consequences of migration can arise from three externalities: material, technological and market distortion. (Romans 1974 in (Greenwood, 1975)) Portes and Böröcz consider guest working much more a social than an economic process, urging the importance of migration social networks. (Portes \& Böröcz, 2001)

On a macro level Papademetriou considers migration economically and socialpolitically an inadequate institution because the overall benefits of the sender country are small, while in the receiving country the benefits are lower than the social and political characters given by the presence of the migrants. (Papademetriou, 1978) Several origin countries suppose that migrants return home when they get unemployed in the receiving country, but researches show that otherwise. Responding to this, different programs were created to bring home their citizens. The success of these programs is various, their appearance is characteristic to Switzerland. (Kubat 1984 in (Coleman, 1995))

Starting from the hypothesis of relative deprivation it can be supposed that migrants don't want to change - necessarily - the absolute income of the household, instead they hope to change their position referring to a specific reference group. ( Stark, 1984, Stark \& Taylor, 1989 in Stark \& Taylor, 1991) This reference group for villager guest workers is the urban life-style and the consuming patterns of other migrants. In the case of migrants originating from towns and cities the foreign experiences are more obvious than in the case of those who came from villages.

Migration itself is a selective procedure, but a second selection is done, by the employees who favor young, skilled, dynamic workforce. This is called "skimming off" or "double selection" (Baucic, 1974, [ILO], 1973 in Papademetriou, 1978) and has severe consequences in the origin country. Results in a lack of skillful workforce and the investment of the society in the human capital of the migrant brings no benefits because knowledge is taken across the borders, thirdly the places of these workers is taken by less educated, less skilled workers. It is obvious that on the contrary of expectations - that migration has a positive impact to the life of others as well, not just the closest family members - the migration of skillful workers affects negatively nonmigrants. (Papademetriou, 1978) 
When speaking about consequences of migration the "Melting Pot" is an often used and discussed term. The main question is what happens to immigrants, do they keep their ethnic identity or do they assimilate? Portes calls attention to the fact that this process happened, but not with everybody and not in the same measure. (Portes, 2000) Some groups after 1-2 generations integrated into the "white" culture of the US, others tried to hold on to their identity, while a third group refers to those who understood integration idealized, and fought for this, but were refused. The poverty and integration problems characterizing the first generation migrants in general is altered with the second generations acceptance in economic and social circles. The study of the second generation gives the researcher the possibility to see the long-term consequences of migration. (Portes, 1994)

Several ethnic entrepreneurship case studies can be found, but we have to go along with Letenyei when he states that new summaries regarding ethnic economies agree that ethnic researches can't be seen as a uniform theoretical frame, instead they allow different anthropological, sociological and economic approaches. (Letenyei, 2002: 879) Ethnic entrepreneurs use their ethnicity and group characteristics as resources. (Boissevain, 1990 in Waldinger, Aldrich, \& Ward, 1990: 131) Then again the topic of ethnic identity is strongly connected with the acculturation of immigrants as well. It is hard to answer how the ethnic map of a country is shaped by migration. One of the basic problems is what (Coleman, 1995) discussed: being a foreigner is not necessarily immigrant, and being an immigrant is not necessarily being a foreigner.

Guest workers rarely have social insurance or if they do have it, is restricted. Research demonstrates that seasonal character changes into long time migration or even emigration (Castles, 1994, Soysal, 1994) especially if their situation in the receiving country is safe and trusting. For the receiving country is important to know the proportion of immigrants who are part of the „welfare society”. Jörgen Hansen and Magnus Löfström sought the answer to „Do Immigrant Assimilate Into or Out of Welfare" and they found out that immigrants are more likely to be taking part in the welfare system than locals, but as time passes by this tendency is decreasing. (Hansen $\&$ Löfström, 2003) Finding indicators of long-term welfare forecasts incluyding migrants is still difficult because it is not obvious who are returning and who are remaining in the receiving country and enjoying the rights and benefits of that country as citizens.

The capitals earned during working abroad can be interpreted on several levels. Economic sociology studies migration investments at a personal, household or 
community and macroeconomic level. The money sent home first of all has an impact on the closest, personal circle of the migrant, his/her family. The well being of the family, of families result in a growth of consumption and since migrants bring home luxury goods or the claim of possessing these items, the standard of living also seems higher. The fall back is due to the fact that although needs and ways of living is catching up to modern life-styles and wages in the origin country remains the same. Migration has a double effect on the country of origin, on one hand the earnings are spent by the family that still lives in the country, they buy goods that previously were seen as a luxury but after the migration experiences are accessories of modern everyday life, on another hand amongst other migration it means the loss of human capital.

Using the concept of "transnational social fields" Levitt and Glick-Schiller argue that social scientists have to step forward from thinking in national boundaries, with more and more individuals enrolling in foreign migration analyzing only what happens inside of a country is not enough and certainly incomplete. They argue that "central to the project of transnational migration studies, and to scholarship on other transnational phenomena is a reformulation of the concept of society." (Levitt \& Glick Schiller, 2004:1003) Seeing migrants only as members of the sending or the receiving country gives only a part of the picture but not the entire one. In order to see the full image things should be seen through the lens of transnationalism.

Transnational migration is a network phenomena, its development means the activation of complex local or transnational social networks that directly depend on the country and the migration antecedents. (Sandu, 2005) The second and third generation of migrants is following the footsteps of the first generation, by going along the ties of previous migrants. At the first step the human capital seems less important than the network capital. The explanation is logical, network capital can help to solve traveling problems, can help in finding a place to stay, can make the foreign environment more familiar, etc. The significance of the human capital appears when the seasonal migrant decides that he will be a long time migrant or even he will remain in the receiving country. Human capital might play the role of root cause in the process of emigration. The snowball character of transnational migration results in the appearance of homogenous areas, localities formed by migrants, which can be considered a latent long-term consequence. Transnational communication networks should be taken in consideration in the analysis of development of a society. (Sandu, 2005) 
Consequences of migration can be grouped, based on the level of investigation, whether it refers to the sender or the recipient country and based on the intended/unintended dichotomy. Another aspect is given by the longitude of the consequence whether it lasts for a long or a short while.

When analyzing the consequences of migration, an important role is played by diasporas and equal importance goes to the change of relations among home countries and their diasporas. Shain sees different factors that influence how countries relate to their members living in another country and different postures vary on several criteria such as "the national ethos of the country of origin; official and societal perception of emigration in general; reliance on the economic investments of diaspora (emigrants, refugees, or exiles) and its general attitude toward the home regime; the political role assigned by the home regime (or its opposition) to the voice of the diaspora in domestic or international affairs of the home country; citizenship laws (ius sanguinis vs ius soli ${ }^{30}$ ) and especially the possibility of holding dual citizenship." (Shain, 1999-2000:662) The diaspora can mean a great economic, political and support force for the home community. Diaspora members can influence not only the life of their small family, not only those who are in direct contact with them, but in the case of strong diasporas - the Greek-American diaspora as Shain suggests - the economic power can influence the political campaign and elections as well.

It is very important to have an overview about the long term and short term consequences of migration observed in sending and receiving countries because in the csángó elites migration and its consequences are very much present in both countries first of all on a personal level but approaching the topic more generally on meso and macro level as well.

\footnotetext{
${ }^{30}$ Right of blood vs. Right of soil
} 


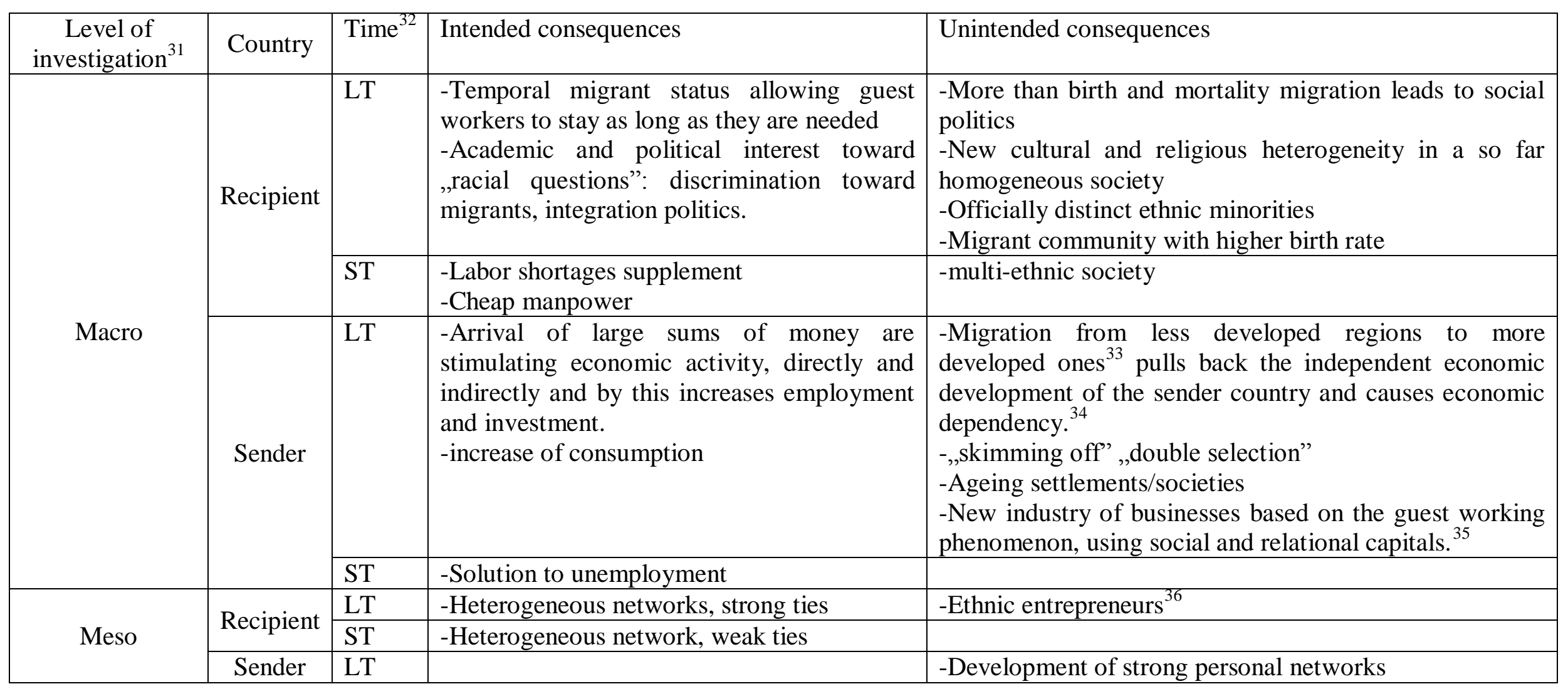

\footnotetext{
${ }^{31}$ Macro level refers to the national, regional consequences, micro is the personal, individual consequences, while meso level reffers to consequences that can be observed on the level of small groups and/or through networks.

${ }^{32} \mathrm{LT}$ stands for Long term consequences, ST stands for Short term consequences

${ }^{33}$ Migration refers to mass employment

${ }^{34}$ Mohácsek-Vitos 2005:214

${ }^{35}$ such a business is the ,local commuter routes” in Széklerland

${ }^{36}$ (Coleman 1995:191) Indians and Pakistani/Bangladeshis are almost twice as likely to be self-employed as are whites particularly in small businesses, restaurants and retailing, while West Indians are only half as likely to be self-employed.
} 


\begin{tabular}{|c|c|c|c|c|}
\hline & & & & $\begin{array}{l}\text {-Increase of tolerance level } \\
\text {-Reference group based on consumption patterns } \\
\text {-In the case of villages consumption patterns are aiming } \\
\text { the urban life styles and consumption patterns of other } \\
\text { migrants }\end{array}$ \\
\hline & & ST & & -Weak ties are detached, strong ties remain \\
\hline \multirow{4}{*}{ Micro } & \multirow[t]{2}{*}{ Recipient } & LT & $\begin{array}{l}\text {-Cheap manpower for employees as long as } \\
\text { needed } \\
\text {-Confidence of workers, to whom better } \\
\text { circumstances are ensured than home, and } \\
\text { who are not as integrated to search for other } \\
\text { job. }\end{array}$ & $\begin{array}{l}\text {-Rejection of the environment because „strangers” were } \\
\text { brought among them } \\
\text {-Patron-client system with advantages of the patron }\end{array}$ \\
\hline & & ST & $\begin{array}{l}\text { - Cheap manpower for employees as long as } \\
\text { needed }\end{array}$ & -patron-client system: advantages of patrons \\
\hline & \multirow{2}{*}{ Sender } & LT & $\begin{array}{l}\text {-Economic welfare for the family of the } \\
\text { migrant } \\
\text {-Direct investment of the home brought } \\
\text { money, development of the community }\end{array}$ & $\begin{array}{l}\text {-Increase of tolerance level } \\
\text {-Patron-client system, with advantages but also } \\
\text { disadvantages of the client } \\
\text {-Difficulties of integration at return }\end{array}$ \\
\hline & & ST & $\begin{array}{l}\text { - Economic welfare for the family of the } \\
\text { migrant } \\
\text {-Advantages based on international and } \\
\text { cultural experiences, knowledge at return }\end{array}$ & $\begin{array}{l}\text {-Patron-client system, with advantages but also } \\
\text { disadvantages of the client }\end{array}$ \\
\hline
\end{tabular}


Investigations focusing on the migration processes of Csángós and its consequences are also appearing, yet these are mostly case studies. Pozsony finds ${ }^{37}$ that in 2001 in Magyarfalu 21 household heads were working in Israel and 5 in Hungary, as it concerns their children 38 in Israel, 30 in Hungary, 5 in Italy and 1 in Greece. In the same time in Klézse nearly one quarter of the locality accepts work only abroad. (Pozsony, 2003) It is important to know that Magyarfalu is a very segregated village and enrolled into international migration processes much later than several other villages. For example Klézse, the largest Csángó village, which is close to Bákó and is nearby to the county road - with good infrastructure - was one of the first enrolled in migration to Hungary and later to other countries. One interviewee pointed out that until men from villages like Magyarfalu went to Hungary those from Klézse went to Italy together with their wife and family.

Hegyeli sought to present the effects international migration has on the csángó culture and society. One of the most useful observations drawn by Hegyeli is the differentiation among "surface type effects" and "structural type effects". Surface effects are those that are not influencing the deeper layers of the society, usually these have a temporary character (trying to apply things seen abroad such as the way of dressing, speaking norms and even working processes they accumulated abroad are in this category since they don't know the entire procedure of that work only some phases). The author recognizes that this has a twofold role, firstly it is seen as "acting", secondly these are the symbols of success as well. Hegyeli concludes that the effects are not structurally integrated and when migrants return home these influences stop affecting and migrants are adapting to the traditional life form. (Hegyeli, 1999)

The study of Mohácsek and Vitos on the consumption patterns of migrants from Magyarfalu, differentiates productive and unproductive personal consumption. The consumption of migrants first of all aim to "serve personal needs instead of economic investments." While on personal or family levels migration has positive effects by ensuring a better lifestyle, the community does not benefit from it and although there is no structural economic development innovation and new models to prevail appear. (Mohácsek \& Vitos, 2005)

\footnotetext{
${ }^{37}$ The article of Ferenc Pozsony discussing the social stratification of Csángó villages first appeared in Romanian (Pozsony, 2002) than as an article in Hungarian (Pozsony, 2003) than the Romanian language book was published in Hungarian. (Pozsony, 2003).
} 
Larissa Adler-Lomitz conducted fieldwork among Csángó guest workers living in Budapest, focusing on their information channels. About their migration find that "occurred almost on an individual basis supported mainly by the social networks of migrants and by the relative ease that they had in obtaining tourist visas, work, and housing in their new society, as well as by a symbolic acceptance by the Hungarian community of the primordial role of the Csángós in Hungarian nationality." (AdlerLomnitz \& Gonzalez, 2007:84) Although the authors give great importance to the inbetween self identification of Csángó (migrants) who didn’t identify themselves as Romanians but as arrived in Hungary couldn't identify themselves as Hungarians either, the most interesting finding referred to the effects of migration on the out-migrating society, findings that were strengthened couple years later by my field experiences in Moldova as well. The increased standards of living through construction of modern housing, the introduction of cars, television, refrigerators and Western forms of dressing for the young people, as well as more money to improve their nutrition as some of them. From being working class producers in the places of destination, upon returning to their places of origin they became consumers of merchandize produced in the places of destination. We also noticed a greater interest in the education of their children, preparing, therefore, the countryside to be part of the European Community. (Adler-Lomnitz \& Gonzalez, 2007:84)

Veronika Lajos concludes her article saying that the given presence of transnational networks should be taken in consideration beside the obvious topics of relations among the out-migrating community, short and long term migrants and emigrants in the investigation of identity and religion among csángós as well. (Lajos, 2006)

There is a meeting surface of migration theories and social network theories, the social capital of migrants is a topic often investigated. The importance and presence of migration relations was noticed by Thomas and Znaniecki. (Thomas \& Znaniecki, 19181920) Relations among out-migrating and receiving countries are sustained on an institutional level and on a personal level as well, on the other hand these networks might sustain the migration process even if the economic situation would not indicate so. (Massey, 1987). Geographic migration patterns are also due to having migration channels and relations among out-migrating and receiving countries. (Salt, 2001) Tilly and Brown sought to present the role kinship plays in migration and assimilation naming "the auspices of migration”. (Tilly \& Brown, 1967) Boyd argues that social 
network are sustaining not only economic but social and political structures as well of both the out-migrating and receiving country: Social networks based on kinship, friendship and community ties are central components in migration systems analysis. They mediate between individual actors and larger structural forces. They link sending and receiving countries. And they explain the continuation of migration long after the original impetus for migration has ended. (Boyd, 1989:661) Meanwhile Fawcett suggests a framework with three types and four categories of linkages that are associated with the "flows and counterflows of people in a migration system" and can be used in "identifying interactions that may be critical to understanding the dynamics of migration flows. A key example is the interaction between regulatory linkages and family networks." (Fawcett, 1989:67-68) 


\subsection{Methodology and data}

Kezar starts her methodological article referring the principles and problems of Transformational Elite Interviews saying that "Although elite interviews are an important tradition in the social sciences, literature on the epistemological issues involved in such research is scant." (Kezar, 2003: 396)

During fieldwork the first goal was to receive feasible field knowledge, to understand the relations, to recognize the actors and to speak the same language, to use similar concepts that the subjects do. Before starting to work on this research, through my personal network I was connected to several Csángós who were learning in Budapest. Starting with the summer of 2006 I spent longer or shorter periods of time in Moldova, and since the beginning of my $\mathrm{PhD}$ studies in Budapest I've got an insight to the life and concerns of those who came to study with a scholarship given by the Hungarian state and after graduating returned home or chose to settle in their receiving country. Deciding who is part of the Csángó elite, proved to be the toughest question of the research, not only to the more or less outsider researcher but to well informed insiders as well. Three methods were used in a structured manner, interviews were conducted, relational data was collected and questionnaires were filled in one locality.

Conducting elite investigations requires a very operational methodology. Most members of the elite are highly educated and better communicators than the average people. It is important to find and to use those methods that can collect the data needed in order to answer our questions. Dealing with a hidden community in a sense that is hard to define its members the classical methods used in sociology - and classic elite investigations as well - are not operational.

During data collection name generation questions were used. In order to reveal the Csángó elite group, snowball sampling was used, initiating name generation with 4 subjects, who were named by several Csángós as the most visible, the most obvious elites. At the end of each interview, subjects were asked to name who they consider Csángó elites and why they see them as such. Second name generator question is linked to the relational data, when respondents were asked to name all those with whom they are collaborating in the Csángó matter.

During the interview data was collected referring to their interpretation of being elite and the duties one has to fulfill in order to be seen as such. In case of nominations we also asked to explain why they see that specific person as Csángó elite. This approach - beside the uncertainty of the group composition - was also required because 
after the 1990s the Csángó (folk) culture became very fashionable in Hungary and nowadays it is promoted and supported by several NGOs and politicians. Snowball sampling was the optimal way to encounter those subjects that are seen as elites by other Csángós, instead of creating some categories based on previous studies and former readings, categories that later on should have been filled with appropriate context, it seemed wiser to see the "filling" first and create the categories, the definition later. Although interviewees knew the topic of the research, information was given only in key words rather than a detailed, well defined topic description. As Lee points when conducting indepth interviews on sensitive topics, the boundaries of a topic should be kept wide enough for the interviewed to be able to give his/her own definition of it. (Lee, 1993)

Following the snowball sample the goal was to reach as many nominated persons as possible, and through a half-structured interview, data regarding their lifeexperiences, opinions and roles in the Csángó matter were collected. Information was collected regarding their studies, life course, life style, migration experiences if such, their vision about the Csángó elite and its situation, duty and role in the everyday life of the community, the probable future of the youth. Relational data was for the collaboration in the Csángó matter, namely with whom are they regularly working together in events concerning the Csángó matter.

When one conducts a network analysis based on the character of the study and the level of research can choose from two methods, to do a whole network analysis through which the relations of a well defined and/or formal group are under the magnifying glass; or can vote for an ego-centric network analysis. In this latter case the focus is turned to one member - the ego - of a specific group and the relations are referring to his/her interactions inside of that group. A specific subset of the egocentric network analysis is the study of personal networks which is different from other egocentric studies by not constraining the relations of the ego to only one group, organization, institute, etc., but by collecting data regarding the ego with any kind of relationships. Although the personal network analysis offers a great variety of information and as such a multitude of explanations to the context in which the subjects are embedded and active, it is important to know and to acknowledge that basically we are interested in the size of the activity and about how well is one known as someone dedicated to the Csángó matter. Simplifying the choice of network analysis, the - only possible and realizable - option is to conduct a whole network analyze, noting that the 
concept of "whole" in this case is an exaggeration, asking all people involved in the Csángó matter is not only impossible but probably unnecessary as well. Another important note is that many actors of the cooperation network are linked to each other in several ways, it is not rare to find entire families involved in the matter, as such being colleague, relative and friends, etc in the same time is not unusual.

Another differentiation can be followed through these networks. Depending on the level of the investigation three types of networks can be differentiated. When the social entities are individuals, the network is of interpersonal relations. If the related entities are social groups the network is among social groups, classes or organizations, while when relation is referring to countries or regions, then the network is among these entities. (Szántó \& Tóth, 1993: 45)

When analyzing the Csángó matter it is logical to start from the simplest case, the network(s) of interpersonal relations followed by the network of social groups.

In order to follow up the position of elites in different networks, investigation starts from the network containing only the elites as Egos - those respondents that named their relations regarding the Csángó matter - then to this network alters named by them were added, then those respondents are added that are representing the most important organizations present in the topic. As a following step teachers of the MCSMSZ, employees who are active by their job in the Csángó matter were also added. During interviews it became obvious that for the elites it is the most important to act in the duty of the community, to be active in the Csángó matter, that is why the name generator is feasible.

When speaking about relations among organizations it is very important to clarify that being highly embedded, makes it hard to decide whether the relation is actually among organizations - sustained by representatives - or among individuals. Relations analyzed at the level of regions and countries are also included in the network analysis. It is a question to be answered whether the Csángó elite is viable, if they manage to keep the central positions in the network while other actors are added. For the study of networks, two softwares were used: EgoNet (http://sourceforge.net/projects/egonet/) was used to collect and merge relational data received from subjects and UCInet6 (http://www.analytictech.com/ucinet/) for the actual analysis of the cooperation networks.

While in the case of quantitative investigation there is a more or less accurate number of a sample needs to have, in order to give reliable and generalizable 
information - see how (Rudas, 2006) explains the relation among the characteristics of the population desired to be investigated, the sampling method and sample size- in the case of qualitative research there is no such guideline to follow. Even so the size of the sample and sampling is just as important only that is up to the investigator to decide whether adding a new subject to the investigation would bring new insights, extra information. Literature stresses that including new subjects is not necessary if by that no new information would came to light. At this point the sample size can be considered optimal. (See (Patton, 1990), (Seidman, 2003) and others) We can conclude by using the word of Odendahl and Shaw that in our case "The identification of individual elites and the compilation of subject pools are only the beginning of a protracted process involving several layers of additional research.” (Odendahl \& Shaw, 2001: 305)

Ethical concerns are highly important in handling interviews, due to this, before accepting the interview, subjects were assured that the information received from them will be managed with anonymity and discretely; although several subjects said that all they say can be quoted and they publicly undertake their affirmations and opinions. To assure a comfortable location interviews were conducted at a place selected by the interviewee, in most cases this was his/her residence, if it was any other location by the interviewee got started we managed to rule out all disturbing factors and only the interviewee and I were present. Similarly to interviews, relational data is also a sensitive topic even if in this case it refers to cooperation relations in the Csángó matter, since the matter includes economic and political aspects as well subjects appear nameless and necessary codes were given in order to maintain anonymity as much as possible.

All data received with qualitative methods was collected personally, while in the survey investigation I received some help from five local girls. During the qualitative investigation only the first and last question was fixed, the order of the other topics was given by the thread of the discussion. Adjusting the order of questions according to each interview is sustained by the literature as well. (Héra \& Ligeti, 2006) The length of the interviews was different, from one hour to nearly 5 hours.

32 interviews were conducted mostly with members of the Csángó elite - some of them representatives of organizations as well - and the leaders, or one of the leaders of 4 important organizations. Interview subjects were selected through a snowballsample (Who do you consider as member of the Csángó elite? for all nominations justification was also asked, respondents were asked to give their own elite definitions), focusing on those who were named more than twice. 


\begin{tabular}{|c|c|c|c|c|c|}
\hline & \multicolumn{2}{|c|}{ Elite } & \multicolumn{2}{|c|}{ Representative } & \multirow[t]{2}{*}{ Total } \\
\hline & Hungary & Romania & Hungary & Romania & \\
\hline Csángó & 14 & 5 & 5 & 3 & 27 \\
\hline Not Csángó & 0 & 0 & 2 & 3 & 5 \\
\hline Total & 14 & 5 & 7 & 6 & 32 \\
\hline
\end{tabular}

Table 2: Distribution of interview subjects

Relational data was collected from 44 persons. The ego-network regarding the collaboration in Csángó topics was collected from several subjects, later these egonetworks - using ego-net software - were merged into one network, showing all named collaborations. Relational data was collected from elites, representatives of organizations and non elites as well. Csángós who are elites and representatives as well are included as representatives.

\begin{tabular}{l|rr|rr|rr|r} 
& \multicolumn{2}{|c|}{ Elite } & \multicolumn{2}{c|}{ Representative } & \multicolumn{2}{c|}{ Not elite } & \multicolumn{1}{c}{ Total } \\
& Hungary & \multicolumn{2}{|c}{ Romania } & \multicolumn{1}{|c}{ Hungary } & Romania & Romania & \\
\hline Csángó & 14 & 5 & 5 & 3 & 0 & $\mathbf{2 7}$ \\
Not Csángó & 0 & 0 & 2 & 2 & 13 & $\mathbf{1 7}$ \\
\hline Total & $\mathbf{1 4}$ & $\mathbf{5}$ & $\mathbf{7}$ & $\mathbf{5}$ & $\mathbf{1 3}$ & $\mathbf{4 4}$ \\
\hline
\end{tabular}

Table 3: Distribution of respondents of the relational data

In order to receive feedback of the elite generated by the snowball sample and to have a comparison front of elites and the community, representative data was collected in one locality. 182 questionnaires with 17 questions were asked in Magyarfalu, the most eastern Catholic village, being close to Bacau and Vrancea as well. In the community many still speak the Csángó dialect. The locality, according to clerical statistics from 2007, is of 430 families and 1.418 people. (Anon., 2007) With the 182 questionnaires nearly half $(42,3 \%)$ of the families were selected.

Five local girls - studying in 9-12 grades - were asked to go to every third house and fill a questionnaire - either in Romanian or in Hungarian as the respondent wishes with the household head (the father who usually is the one with income and if he is abroad than with the wife). Opting to fill out with the household head was led by the fact that in the village mostly or nearly exclusively men are those who work in Romania or in other countries and their wives are at home. Men have a more accurate insight to migration and its consequences and their opinion is valued differently. First questions refer to the demographic characteristics and migration experiences (or plans) of the respondent. Same questions being asked from elites as well, these questions are called to give a base of comparison. The last three questions are interested in the opinion about the Csángó elite. 
The multitude of methods and approaches aimed to give feed-back about the composition of the elite and the prestige and recognition of the members. Quantitative data is used to test results drawn from the qualitative investigation. Légmán (2011:72) made the following table about the place of qualitative methods in elite investigations.

\begin{tabular}{l|ll} 
& $\begin{array}{l}\text { "Independent" qualitative } \\
\text { investigations }\end{array}$ & $\begin{array}{l}\text { "Additional" qualitative } \\
\text { investigations }\end{array}$ \\
\hline Theoretical background & Globalization theories & $\begin{array}{l}\text { Classic elite theories } \\
\text { Political, economic, } \\
\text { cultural elite }\end{array}$ \\
Topic of the investigation & New (global) elite & $\begin{array}{l}\text { Describing elite groups, } \\
\text { implementing quantitative } \\
\text { investigations, testing data }\end{array}$ \\
$\begin{array}{l}\text { Relation to the investigation } \\
\text { quantitative methods }\end{array}$ & $\begin{array}{l}\text { Describing elite groups, } \\
\text { presenting life styles, and } \\
\text { roles of individuals }\end{array}$ & $\begin{array}{l}\text { Additional, subordinated } \\
\text { Peer, individual method }\end{array}$ \\
\hline
\end{tabular}

Table 4: The place of qualitative research in elite studies, in Légmán (2011:72)

Presenting the pros and cons of the interviewing as data gathering, Lilleker underlines that as much data can be collected by interviewing, one has to be very clear that using solely this method has serious fallbacks and must be confirmed by other data or the interview sample should be very broad with the same odds for everyone to be selected as subjects. (Lilleker 2003:208)

\footnotetext{
"Interviews do provide insights into events about which we know little: the activities that take place out of the public or media gaze, behind closed doors. We can learn more about the inner workings of the political process, the machinations between influential actors and how a sequence of events was viewed and responded to within the political machine. Though one has to be aware that some details may be exaggerations or even falsehoods, a point to which we will return, suffice it to say that interviews can provide immense amounts of information that could not be gleaned from official published documents or contemporary media accounts." (Lilleker 2003:208)
}

Confirmation or refutation of the elite group/composition drawn by the snowball sample is a result that is worthy to think through. Obviously the optimal result would be to have a confirmation that those members that are named as elites by other elites are seen as such by the community as well. The probable situation in this case is that from the named elites those will be named in the questionnaires that are from the village where the quantitative investigation was done. Even if questionnaires will refute the composition of the elite - if not even members from the home-village of the respondents 
will be sustained in their elite position - it is still an important result. It would mean that there is a discrepancy between the prestige attributed to some persons and/or people who are settled outside of the community, left the village and as such are not present anymore in the local public opinion.

\subsection{Hypothesis}

The research seeks to answer whether the statement encountered in the literature concerning Csángós namely that the community lacks the intellectual, the elite strata, is still available. The basic assumption that launched this investigation was that the goal named by organizers of the Hungarian teaching namely that from the beginning of the '90s we can speak about the nurturing of the Csángó elite. Hypotheses, grouped around three questions, aim to present this elite, and these elite members. The first hypothesis, wishes to define the elite and to identify its members according to their network roles and positions, second concerns the migration aspects of the Csángó elite, while third seeks to present how migration experiences and network roles and positions are interacting together. Throughout the hypothesis testing the validity of the qualitative data is checked with quantitative analysis as well.

\section{Hypothesis 1.: Network roles and positions}

One of the primary roles fulfilled - and expected from - by elites, is to represent their community. One - and the most obvious - channel to represent the Csángó community is by having an active role in the Csángó matter. Being present in the Csángó matter increases the odds of being seen as elite by others, as such fulfilling key positions ensures the elite nomination. Activity in the Csángó matter is grouped around two questions, one referring to the individual roles fulfilled, and second concerning the composition of the elite as such (formed by competitive or collaborative groups).

Hypothesis referring to the central position of elites assumes that they are known by others as key figures, they are connecting different organizations, institutions and events.

Hypothesis 1a. Elites will fulfill the roles of opinion leaders and opinion brokers.

Question 1a. Who are representing the Csángó matter and are known by all interested in the Csángó culture and are linking together individuals or groups. What are the central events and institutions?

Source of information 1. Networks

Indicators 1. degree, indegree, betweenness, egonet broker. 
The Csángó matter, the preservation of the Csángó culture is a common goal that brings together all interested in it, and regardless of personal interests or ethnic identification persons and organizations are collaborating with each other.

Hypothesis 1b. Having the common goal of preserving the Csángó culture, elite groups are collaborating regardless of their organizational, ethnical, personal, etc. interests.

Question 1b. Can we differentiate competing groups or they are rather working together?

Source of information 1b. Network+ Interviews

Indicators 1b: cooperation among elites and elite groups

\section{Hypothesis 2.: Migration}

The Csángó elite, or at least - an important part of it - was nurtured in Csíkszereda and later in Hungary, others learned and worked in different parts of Transylvania, Hungary or west Europe. It is logical to think that the new places and new cultures brought new insights to migrant Csángós, who with the accumulated knowledge managed to step out from the mass. The higher prestige that goes hand in hand in the Csángó villages with the migrant status, sustained by the accumulated knowledge ensures higher odds of being seen as elite. Migration from Moldova and from the Csángó villages is not pointing only to these two locations. The migration to Transylvania and Hungary is not even the greatest in number (today). Many Csángós are working in Italy, Spain, UK, etc, yet the migration to these two locations are/were often with the goal of learning.

Hypothesis 2a. Migrational experiences especially to Transylvania and Hungary have a positive effect on the odds of being elite.

Question 2a. What importance is given to migration experiences? What is more important in personal and community level development, education or guest working?

\section{Source of information 2a: interviews}

Indicators 2a. narratives referring migration experiences and the dichotomy.

The following hypothesis is launched by the curiosity whether it is possible for a community to have its elites abroad. During data collection no geographic boundaries were given, and many nominations pointed out as elites, person living in Hungary, 
mostly Budapest. In order to answer the question the list of elites and the list build up in one locality were compared. A high degree of overlapping is unimaginable, since one locality (although question 15 gives the opportunity to name persons from other localities, too) is compared to the total community. Yet, if at least elites originating from that specific locality are seen as elites by the locality as well, presumably other villages would do similarly. The last questions of the questionnaire are asking to name the elites, most important characteristics that an elite should have and the top 10 people from the village.

Hypothesis 2b. Migration experiences have a positive effect on being elite.

Question 2b. Does living abroad bring higher prestige in the eyes of the emissive community?

Source of information 2b.: questionnaires

Indicators $\mathbf{2 b}$. Comparing the last three questions of the quantitative investigation conducted in one village with the snowball method selected elite

\section{Hypothesis 3.: Migration and network roles and positions}

Presumably for those members of the elite who are not present in the everyday life of the community - they live abroad - activity in the Csángó matter is more important than for those who remained in Moldova.

Hypothesis 3. For elites living in Hungary activity in the Csángó matter has a greater importance (measured with activity in the cooperation network) than for elites living in Moldova.

Question 3. How does transnational migration influence ones odds to be seen as elite? Is activity in the Csángó matter more important after migration than prior to it?

Source of information 3.: network data and statistics used with SPSS

Indicators 3.: interaction effect among elite nomination, centrality and place of residence.

The following table contains the main issues of the research, WHAT are the basic questions and hypotheses, WHAT KIND of causality can be observed among variables, HOW are they conceptualized and finally from WHERE is the data and information derived from. It is obvious that some of these hypotheses can't be analyzed through a cause-effect relationship, so their explanation as such is somewhat strained. 


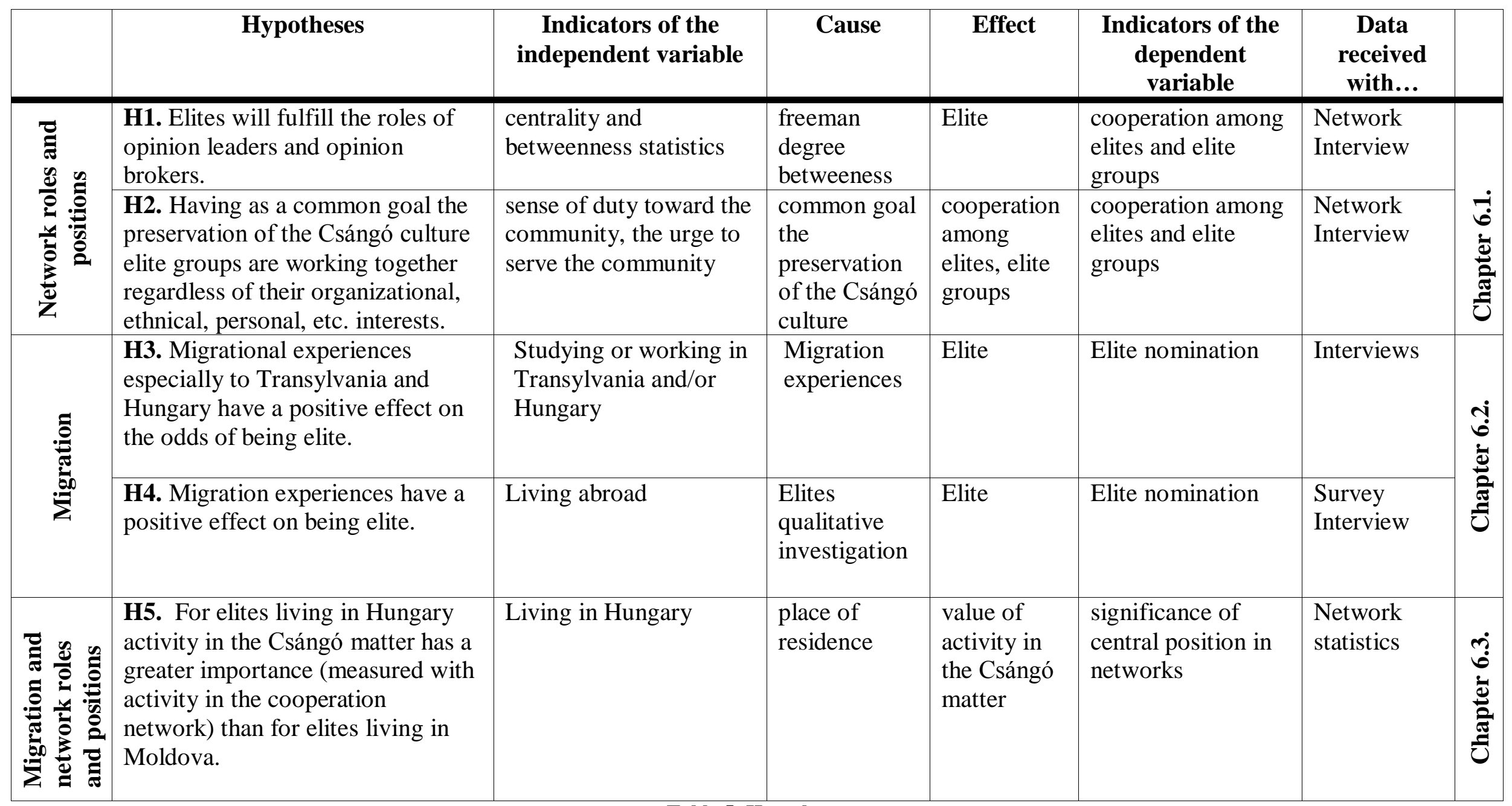

Table 5: Hypotheses 


\section{The Csángó matter}

Mottó:

„Az lenne az igazi és eredményes, ha egyenként és együtt nem menteni kellene a csángómagyarokat és magyar-csángókat, hanem a helyi, az alulról épitkezö törekvések találkoznának az országos, a kárpát-medencei és az európai kis kultúrákat védö és mentö szándékokkal, társadalmi és hitbéli akarattal. Itthon is, Brüsszelben is, a Vatikánban is. „38

Sylveszter Lajos

The elite and the Csángó culture as well, can be characterized based on different aspects. The specialized literature recognizes as fact several events and situations, and their support or denial mostly depends on the researcher's approach. Tánczos points out that we should count with the fact that politics and its applied forms - such as social-, religious-, cultural-, etc - in the Csángó research are not firmly separated from science. (Tánczos, 2001: 54) Diaconescu similarly sustains, that uncertainties in the identity and self-identification of Csángós were strengthened by the discourses - official ones or not - of the two camps (Diaconescu, 2005). The author sees a close relation among politics and historical myths, concluding - for the Romanian and the Hungarian historiography - that the more political controversy represents a topic, the discussion of it will be more cautious. There are several interested in the Csángó society or some aspects of it. Delaying the assimilation, preserving as much as possible from their culture and presenting the society, history and everyday life of their origin society and the one of their ancestors became a goal to those Csángós who learned and earned a degree in a higher educational institute in Transylvania or Hungary. This goal is usually mentioned as the "Csángó matter" 39 which is multi- and cross layered. These layers often overlap and in some cases they present and represent the same ideas, although they do that without interacting with other actors. Parallel interests and solutions - or at least ideas of solutions - can be observed.

The previous chapter presented the questions collected with interviews. Some of those questions were selected for a detailed analysis as the main topics of the research. All subjects were asked about their opinion regarding the existence and composition of the Csángó elite. The most important questions are the following: Is there a Csángó elite? Geographically it is situated in Moldova or in Hungary? Based on language and

\footnotetext{
${ }^{38}$ Sylveszter, 2001:232 The real and successful would be if one by one and as group Csángó-Hungarians or Hungarian Csángós should not be rescued, but, the local and down to top efforts would meet the national, Carpathian basin, and interests that are protecting and saving European small cultures, the social and devotional will. At home, in Brussel and in the Vatican too.

${ }^{39}$ Many interview subjects speak about the „Csángó ügy” as a concept clearly understood by all interested in Csángós. Their interpretation and their own role, as well the role of elites in this case shall be discussed later in this chapter.
} 
as such on identity is Hungarian or Romanian? What is the Csángó matter? and What is the role of elite members in it? What is that plus, that extra which can be found in the case of an elite and is missing and desired by others? What has a higher priority of the young generation and why learning and getting a degree or working, mostly abroad and accumulating wealth?

These questions were grouped in four categories to be discussed in four subchapters. First it refers to the existence of the Csángó elite and the characterization of its members. Second it is an institutional presentation, namely the Catholic Church and the relation of elites and the community with the priest. The topic is sustained mostly by the great importance of priests, seen as the "supreme elites". The third topic concerns the ethnic self-identification of the elite members while the last topic refers to the conflicts originating from the ethnic self-identification, the Romanian-Hungarian conflict.

Results and hypothesis are grouped around these main topics. Before investigating any of them, first and most important topic to answer and to present is the issue of the Csángó matter, which if defined as short as possible is the preservation of the Csángó culture and the representation of the society. This includes cultural, social, health, religious, education, etc. aspects as well. There are several organizations, foundations, political parties and individuals active in this, or in some aspects of it, maintaining the cultural characteristics, slowing the assimilation process, keeping or reintroducing the usage of Hungarian language, asking for Hungarian masses, publishing scientific works about the past and present of this minority, etc.

In the following pages the goal is to bring together the opinions and expectations regarding the Csángó matter as they are seen by interview subjects. Often, villages and communities are divided by the Csángó matter, while some are supporting it, others are opposing; or favoring or denying only some aspects of it. By presenting the aspects of the Csángó matter, a review of its past 20 years can be done.

Observations made by Brubaker and his colleagues about the goals of Hungarian ethnopolitics in the post-communist Romania bring useful insight on the social, cultural and political stage where the Csángó matter wished to win validity.

"The basic templates that have governed ethnopolitical contention in postcommunist Transylvania were established early on by $D^{4} R^{40}$ claims and Romanian nationalist

\footnotetext{
${ }^{40}$ DAHR: Democratic Alliance of Hungarians of Romania (RMDSZ in Hungarian and UDMR in Romanian)
} 
counterclaims. the DAHR demands an autonomous network of Hungarian institutions, and particularly a separate Hungarian-language school system; the Romanian nationalists characterize these aspirations as separatist. The DAHR demands collective as well as individual rights; Romanian nationalists regard this as an unwarranted claim for special privileges above and beyond the equal rights of citizenship. The DAHR demands the right to maintain and cultivate ties to Hungary; for Romanian nationalists, this calls into question their loyalty to the Romanian state. The DAHR demands territorial autonomy for the Hungarian-majority Szekler region; Romanian nationalists regard this as a threat to the constitutionally enshrined unitary and indivisible nature of the Romanian nation-state." (Brubaker, Feischmidt, Fox, \& Grancea, 2006:122)

Some leaders of the DAHR felt after the regime change that the introduction of Hungarian teaching into the education of Csángó children is also necessary, and that the time is just adequate. At the beginning of the 90's it was impossible to make such a change in the Romanian education system in Moldova, as such the only option was to bring the children to Szeklerland. With financial support from the Catholic Church they tried to enroll talented children to learn in middle and high schools. The goal was to find children and families who accept the challenge of being far from each other, and stand up to the change of environment too. Borbáth Erzsébet, a retired school principal remembers that in the first year 17 Csángó parents dressed in traditional dresses were searching for her, in order to ask the basic questions. Some of these questions are still very important, valid and with long-term consequences.

„Ez volt az elsö kérdés, hol fognak lakni a gyerekek? Ki fogja kifizetni a költségeiket, mert
sok gyerekes családból hozzák a gyerekeket, 10-11 gyerek is van egy családban. Ha
nyolcadikat elvégzik hol fognak tovább tanulni, és ha az iskoláikat elvégzik hol fognak
dolgozni? [...] ha itt magyar nyelven fognak ezek a gyerekek tanulni, akkor Moldvába
biztos nem fogadják öket vissza szívesen, mert ott biza azt se veszik jónéven, hogy kihozzák
öket ide székelyföldre tanulni. ... Felelös, nagyon komoly kérdések voltak. " ${ }^{41}$

One of the most important questions was the one referring to work. Planning on long-term it was quite obvious that those children as once left the village and Moldova, chose to learn in Hungarian, their chances to return to Moldova was very low. Yet the assumed goal was to educate them in order that later these children can form the Csángó

\footnotetext{
${ }^{41}$ This was the first question, where will the children live? Who will pay their expenses, because they are bringing children from families with many kids, with 10-11 children in a family. If they graduate 8 classes, where will they continue their studies, and if they finish their education where will they work? [...] if these children are going to learn here in Hungarian, they won't be kindly accepted back in Moldova, because even bringing then to Széklerland to learn is seen as bad thing. ... These were respondible, very serious questions.
} 
intellectual strata. The idea was that they would return to Moldova and as intellectuals would continue to serve the Csángó matter.

In the first year 23 children were enrolled in the $8^{\text {th }}$ grade, and some in the $5^{\text {th }}-6^{\text {th }}$ and $7^{\text {th }}$ grades. In total there were 31 children learning in Csíkszereda. While smaller kids were placed in mixed classes, the 23 eight graders constituted a Csángó class. One of the great difficulties encountered, was to catch-up with other children while they are only getting familiarized with the Hungarian orthography. Having less classes, Hungarian teaching was undertaken by the school principal. Teaching and education had priority regardless if they choose to continue their studies or opt for professional schools after graduating eight classes. In the 90's many factories were still working in Romania so the possibility of finding a job did not seem as difficult as today.

In the past few years Hungarian education in Transylvania is done in the 9-12 grades, while at the beginning of the program it started in the 5-8 classes, so there was a longer period of time to catch up to those who learned in Hungarian all along. Accommodation and assimilation in scholar matters was much easier for those who changed their habitat at a younger age, although they too recall as being very difficult for them as well. Changing residence and everything that goes with it, was a serious challenge.

„Nehéz volt. Csíkban nagyon keményen kellett dolgozni, hála Istennek nagyon jó pedagógusok voltak, és tényleg csodát müveltek, hogy hetedikes gyerekeknek az ábécével kezdték a magyar nyelvtanitást, úgy, hogy az egész oktatásnyelv megváltozott románról magyarra. Legnehezebb a kémia volt, hát egy mukkot nem értettünk ... de nyolcadikba, sajnos nem én, hanem egy diószegi kislány már versenyekre is el tudott menni. Azt akarom mondani ezzel, hogy a kudarc és a siker annyira kézen járt egymással, hogy lehet, hogy voltak nehéz idöszakok, söt valószínü több volt a nehéz, mint a könnyü, de ha hazament az ember a faluba akkor ö volt a sztár. "^2 (36-50 years old employee living in Hungary)

By the year 2000 the Hungarian education of Csángós in Transylvania started to show its results. Teachers who graduated in Udvarhely managed to return to Moldova and were teaching in Romanian schools and kindergartens. When in 2000, Hegyeli Attila - with the support of others active in the Csángó matter - decided to go to

\footnotetext{
${ }^{42}$ It was hard. In Miercura Ciuc we had to work hardly, thank to God there were very god teachers, and they really made a miracle, that for children in the seventh grade started to teach the Hungarian language with the $\mathrm{ABC}$, while the entire education language changed from Romanian to Hungarian. Chemistry was the most difficult, could not understand a word ... but in the eighth grade, unfortunately not me, but a girl from Dioszeg, managed to go to competitions as well. What I wanted to say with this is that, failure and success were going hand in hand with each other, that maybe there were difficult times, probably there were more hard times than easy ones, yet if one went home to the village, he/she was the star.
} 
Moldova, and to start the extra-scholar teaching in Hungarian, young graduated Csángós, with degrees in history, informatics, philology, etc. were also returning to Moldova.

„Ezek a fiatalok egyszerre otthon voltak Attilával, felelös beosztásban, felkészülten, egyetemi képzettséggel és ök jelentették azt a szervezési, politikai, jogi hátteret hogy el lehetett inditani Moldvában az iskolán kivüli szakszerü magyar nyelvtanitást." ${ }^{\circledR 3}$ (older than 51 current leader living in Transylvania)

Two stages of the Hungarian teaching were mentioned so far, the first was organized in Csíkszereda mostly, and in smaller proportion in other towns in Széklerland. The second location is given by those villages where Hungarian classes and occupations are held in the organization of the MCSMSZ. ${ }^{44}$

In 2010-2011 Hungarian teaching was organized in 23 villages in Moldova, where in total 1860 children participated in some form of it. From these 1860 children 983 are enrolled to Hungarian teaching in national schools as well, while 877 participate only to extra scholar activities held in Hungarian language. Another 73 are enrolled in Hungarian higher education, 63 in high schools, 8 to universities and 2 to the NEI. ${ }^{45}$

The introduction of Hungarian teaching in Moldova - a good idea as it is, has its fallbacks too. One named negativity is that by having Hungarian classes in Csángó villages, instead of preparing the field for the 9-12 classes in a Hungarian teaching school in Transylvania it rather hampers it. By bringing children directly to the $9^{\text {th }}$ grade, having all subjects in Hungarian and already learning a profession, preparing for baccalureate when their Hungarian - literary Hungarian - language knowledge acquired in Moldova in many cases is not enough. Romanian is still often used as a primer language among themselves, and the Hungarian is only the language of classes.

Hungary is the third location, where university level education is done, through scholarship from the Hungarian state (about $25.000 \mathrm{Ft} / \mathrm{month}$ in 2008, from which about 12.500 was for the accommodation) and the opportunity to work part time as students (student part time working is very rare in Romania, and scholarship was given only for merit or social/physical disadvantage.) Without a solid family support, studying

\footnotetext{
${ }^{43}$ These young people were at home in the same time with Attila, in responsible positions, prepared, with university education and they meant that organizational, political, legal background that made possible the initiation of the extra scholar professional education of the Hungarian language in Moldova.

${ }^{44}$ Regarding the current number - 2010-2011 - of children enrolled in Hungarian teaching, and their proportion in the total number of children enrolled to schools following table can be found at the webpage of the organization.: http://www.csango.ro/index.php?page=alias-9

${ }^{45}$ For a more data see the Annexes.
} 
in Romania is/was almost impossible. With many young adults who had only a couple years of graduated school years, with few places of work and the temptation of foreign salaries migration with the purpose of work abroad was more than a necessity, it became a life style, a good example to follow, the migrants appeared for many as role models. Many Csángós from the young generation (20-45) traveled to, worked or even studied in foreign countries, some of them settled in the destination country - especially in Hungary - others earnt their money abroad and mostly spent it in Romania.

After one preparatory year in the NEI (Nemzetközi Előkészítő Intézet ${ }^{46}$ ) 10 students are enrolled to universities and colleges in Hungary, with a minimal scholarship and place in a college dorm for foreign students. While at the beginning of the program there was a great oversubscription, in the past couple years, there aren't even the minimum 10 applicants.

„Igen komoly felvételivel vettek még akkor fel a Magyar Nyelvi Intézetbe, mert egyrészt sokan kerültünk akkor középiskolába, másrészt tíz helyet adott a Magyar Nyelvi Intézet a csángóknak, ezen kivül pedig Moldvában, Bákóban, Iaşiban, meg Onyesten mindenhol érettségizett csángó gyerekek is szerettek volna kijönni Budapestre. Ez egy nagyon jó állapot volt a csángók oktatása szempontjából. ${ }^{, 47}$ (younger than 35 employee living in Hungary)

All over the years, the dispute regarding the Hungarian education of Csángós created several opinions. Some think that Hungary is the only place where a child can learn the proper Hungarian, only because he/she has no alternative than to speak in Hungarian. Some think that precisely this is the huge disadvantage, because the children will encounter many negative feedbacks and none or only some positive experiences and they will be strengthened in their Romanian identity, which is quite opposite with the original goal. It would be better to teach them in Transylvania, where they can still use the Romanian language, yet could progress in the daily usage of the Hungarian language. Others think that organizing education of Csángós in Transylvania is not the best solution either; probably the optimal solution would be to have a high school in Bákó. Lately this idea seems to win validity and acquires more and more supporters.

\footnotetext{
${ }^{46}$ International Preparatoy Institute

${ }^{47}$ Back then we were admitted to the Hungarian Language Institute with serious admission exam, on one hand we were many in middle schools, on the other hand the Hungarian Language Institute gave 10 places for Csángós, and in Moldova Csángó children graduated in Bacau, Iaşi and Onesti also wanted to come out to Budapest. This was a very good state as it concerns the education of Csángós.
} 
Csángós living in Hungary strongly criticize that the MCSMSZ is not capable to introduce the Hungarian language in higher education in Moldova, first of all in Bákó. ${ }^{48}$ There is another accusation toward the MCSMSZ namely that they consciously dismantle the education of Csángós at university level in Hungary.

“A 8-9 év alatt, annyira ellehetetlenitette a csángó oktatást, hogy ma már ott vagyunk, hogy a tíz helyre, nincs tíz jelentkezö. Még olyan, sem, aki nem tud egy szót sem magyarul, mert még azt is fölveszik, és még próbálnak valamit belöle faragni. Nincsen, és ez nem azért van, mert nincsenek gyerekek, nincsenek fiatalok, ez azért van, mert az oktatás olyan, silány amilyen. Tehát az, hogy Moldvában magyarnyelvi élményeket osztogatunk súlyos 150 millió forintokért évente, ezt meg lehet csinálni, és még évekig lehet csinálni, de az a legsiralmasabb, hogy még Székelyföldön sem érettségizik évente öt ember. Holott annak idején, még amikor én érettségiztem, akkor nem csak Székelyföldön, hanem a dél erdélyi iskolákban is érettségiztek csángó gyerekek. ... Ráadásul nem beszéltem arról, hogy Székelyföldön már nem arra buzditják a gyermekeket, hogy gimnáziumba menjenek, ahol érettségit kapnak, hanem elég hogyha szakiskolába mennek. "49 (younger than 35 current leader living in Hungary)

Without deciding who is right and who is wrong it is important to realize that the MCSMSZ appeared in a disadvantageous location and situation.

“Az MCSMSZ eleve legalább két szempontból hátrányos helyzetben volt, egyrészt mert a civil szféra szerepét próbálta elsö sorban betölteni, ami még most sem könnyü dolog Romániában, vagy legalábbis ezen a vidéken. Másodszor, civil szféra egy olyan ügyben, amit még a forradalom sem oldott fel. És a magyarországi támogatás az nagyon jó, hogy elindult és most is megvan, de az egész támogatásnak az egyik hiánya, az hogy ezeket, az eseményeket, ahhoz, hogy évenként megtörténjenek, valaki kellett volna gondoljon arra, hogy valahogy megtanitani az itteni közösséget, hogy önállósuljon mert egyszer a támogatásnak is vége less. Ez valahogy elmaradt, és ezért maradt el nagyon sok olyan közösségépitö program, amelyik ameddig volt kívïlröl támogatás, addig meg tudták

\footnotetext{
${ }^{48}$ There was one initiative in this way, Böjte Csaba, a Franciscan monk wanted to build and operate a school that is following Csángó children through the steps of education, from preparatory school to baccalaureate.

${ }^{49}$ In the 8-9 years made the csángó education so impossible, that today there aren't ten applicants for the ten places. Not even those, who doesn't know a word in Hungarian, because even those would be accepted and would try to bring something out of them. There aren't and not because there aren't children, or youngs, it is because education is so poor as it is. So handing out Hungarian experiences in Moldova, for heavy 150 millions yearly, can be done, and can be done for other years, but the most lamentable that yearly not even 5 people are getting a baccalaureate in Szekleralnd. While back then when I was getting a baccalaureate, not only in Szeklerland, but csángó children were graduating in southern Transylvanian schools as well. Plus that I did not speak about the fact that in Szekleraland children are not encouraged to go to high schools where they could receive a baccalaureate, but that it is enough to go to professional school.
} 
szervezni, amikor ez megszünt, mindegy, hogy milyen okokból akkor maga a közösség már nem tudta tovább vinni. ${ }^{, 50}$ (younger than 35 former leader living in Moldova)

Many young Csángós after graduating 8-10 or 12 classes choose to work in Italy or Spain rather than continuing their studies. The possibility to learn in Hungary with scholarship is known only/mostly by those who are studying in Csíkszereda. One way of increasing the number of those who continue their undergraduate studies in Hungary or in Hungarian, could be by sending more children to Csíkszereda, but opinions are divided regarding this idea too. The answer given by the representatives of MCSMSZ to the question why is the decrease of interest toward learning in Hungary, was, that they try to guide children to universities from Transylvania rather than Hungary.

Although presentation of the Csángó matter was restricted so far to educational aspects, the conflict of opinions and interests is obvious even so. The conflict is mostly among the MCSMSZ and Csángós living in Hungary. Some specify this conflict, as a conflict among Csángós and Transylvanians who are in high position at the MCSMSZ.

„Az MCSMSZ és a Budapesti csángó lobbinak a konfliktusa nem egy csángó konfliktus, hanem az MCSMSZ-t uraló erdélyi, leginkább Hegyeli Attilának és az itteni csángóknak a konfliktusa. ... Egyrészt van egy kimondatlan büntudat a Budapestiekben hogy ök ugye eljöttek, másrészt az ottaniakban egy féltékenység, egy harag mert azok eljöttek, ami akadályozza a párbeszédet. Egyébként ez nem egy olyan drámai dolog. Sokkal többet tud itt segíteni az a néhány csángó, mint amit ott a helyben tudna csinálni. Bizonyos fokig föl lehet őket menteni hogy mért jöttek el. ",51 (older than 51 current leader living in Hungary)

Even those who are active in the Csángó matter feel that the solution is not the removal of some people or the withdrawal of some actors from the matter. ${ }^{52}$ As one interviewee pointed out, the solution would be the decentralization of power, by

\footnotetext{
${ }^{50}$ From the beginning MCSMSZ was at least in two fronts in disadvantage, on one hand because it tried to fulfill the role of civil sphere, which is still a hard thing in Romania, at least in this region. Second, civil society in a matter that even the revolution couldn't dissolve. And Hungarian support is very good that started and still exists, but the entire support has a deficiency,namely that someone should've think on teaching the community to be self-sufficient in order to make these events happen on yearly bases, because at one momment supports will end. Somehow this did not happen, and due to this several community building events failed, which until there was foreign support they were organized, when support ended, regardless from what reasons, then the community was not able to take things over.

${ }^{51}$ The conflict of the MCSMSZ and the lobby of the Csángós living in Budapest is not a Csángó conflict, but the conflict of the transilvanian leaders of the MCSMSZ, especially Hegyeli Attila and the Csángós from here. ... On one hand there is an unsaid remorse in those who live in Budapest, because they left from there, on the other hand there is jealousy, an anger because those left, and these are obstructing communication. Otherwise this is not such a dramatic thing. I think that those couple Csángós can help much more here, than could do there locally. On some degree they can be absolved for leaving.

${ }^{52}$ This shall be answered in the subchapter that deals with the network charectrristics of the Csángó matter.
} 
building several bases which are more or less independent rather than searching for someone "perfect" to represent and to lead the Csángó matter.

There is another institution - if not the most important for Csángós - beside schools, where several attempts are made for the introduction of the Hungarian language: the church. It is important to know that the language of masses in Moldova was Latin at the beginning, which was later replaced by Romanian. The official language of the Catholic Church in Moldova was never Hungarian. Just as Hungarian teaching, even the idea of having Hungarian masses, increases conflict among villagers, priests, political leaders, teachers and school inspectorates. In addition to official positions, a variety of private opinions can be observed.

„Tapsi Mihály bácsi volt a legelső mikor meghalta hogy szabadság van akkor elment és kérte a paptól, hogy Tisztelendö Úr jó lenne hogy imádkozzunk magyarul es. Elszitta a pap onnat, majd megverte. Akkor igy az iljenek összefogtunk, s próbálgattuk hogy új gyülekezetet csináljunk. Gyültünk össze, beszélgettünk hogy es lenne, hogy irjunk cerereket, iljen kérvényeket az eskolához, a paphoz. Én es gyüjtöttem vot annak idejében egy oljant hogy majdnem százan iratkoztunk vot fel hogy magyar mise lehessen. Most nem lenne kinek kérjem, most ... 20 esztendeje, azok az öregek mind meghaltak, csak anyám még él azokból és még egy, nincs más azok közül akik akkor aläirták, hogy legyen magyar mise. Ök az idösebbek meljikek ugye még tanultak vot magyarul olvasni abba a három esztendöbe még magyar oktatás vot. Tudták értékelni." ${ }^{, 53}$ (older than 51 employee living in Moldova)

The following quotation is only one from many encountered during interviews and fieldwork. Participant observation even widened the scale of disagreement and agreement. Language, especially in the case of faith and religious life does not have the highest priority.

“A vallás, az vallás, tudod, az Istenben hiszünk, az Isten a fontos, nem, hogy milyen nyelven
imádkozunk szerintem, és én nem eröltetném annyira a misézést. A magyar misézést, nem
eröltetném annyira mivel, hogy ennyi ellentétes, tehát a papok részéröl ütközünk ebbe, és még
a nép sem érett meg arra. Elöször fel kéne késziteni a népet, hogy tényleg kérje ezt a magyar
misét. Értse, s akkor már kérné. Hogyha értené és látná értelmét, mivel ha román, ha magyar
azt mondjuk, hogy Istenhez bármilyen nyelven lehet imádkozni, akkor nem tudom, minek kell
annyira eröltetni. S má az is, ha én jól tudom, akkor sosem volt magyar mise Moldvába. Más

\footnotetext{
${ }^{53}$ Tapsi Mihály was the first who after he found out that there is freedom, went and asked from the priest, that Father is would be good to pray in Hungarian too. The priest sent him away, nearly beat him. Then people like us, we joined together and tried to make a new group. We got together, discussed how we should write applications, applications to schools, to the priest. I collected myself about one hundred signed up to have Hungarian masses. Now there wouldn't be for who to ask, now ... 20 years ago, those olds all died, nly my mother lives from those who signed to have Hungarian mass. They, the older ones who still learned in those three years when it was Hungarian education to read in Hungarian. They knew to appreciate it.
} 
amikor magyar papok voltak, mert beszéltek magyarul, de a mise hát latinul volt, meg aztán románul. S akkor mért mondjuk azt, hogy tegyük vissza a magyar misét. Nem ellenzem, hogyha sikerül valahol örülök neki, mert nincs semmi hátránya de, hogy ezért ilyen táborokat csináljunk, Moldvába, hogy a falut kettéosszuk, meg akár kiabálnak az emberek egymásnak, meg verekednek ... nem éri meg. Nem éri meg, nem keresztes háború, itt a mai világba ez nem éri meg az egészet. Jó hát a vallással sincs nagy baj, nincs nagy harc, a magyarok nem nagy erövel dobták be magukat, de ha van valami erö, akkor inkább valami másra összpontositsunk, ezt hagyjuk békén és imádkozzunk rendesen. És majd ha már annyira barátok vagyunk, akkor már a magyar pap is ott lehet, és akkor a mi házunkba is ... ha ott vagyok, odahivom a rokonaimat és imádkozunk együtt a magyar pappal, de nem úgy, hogy most harcba akarnám belevinni. ${ }^{, 54}$ (36-50 years old employee living in Moldova)

An important factor of the Csángó matter, - assumed by the Teleki Foundation - was to widen the scientific involvement of Csángós in research, to create opportunities to investigate and to present the results concerning Csángó topics. As László Dioszegi, the director of the foundation explained the majority of investigations about Csángós are of etnographic or historical character, while there are several problems that as it concerns Csángós are of a greater importance. Organizing yearly conferences, the foundation managed to ensure occasions and publishing opportunities for the graduate Csángó intellectuals in order to investigate and present several aspects of this minority and its culture. This effort served the same goal of assuring the expansion of the Csángó elite.

\begin{abstract}
„Ami szembetünö volt, hogy annak a doktrínának hogy a csángók azért kiszolgáltatottak mert nincs értelmiségük annak azért a változása kezdödött meg a 2000-es években mert ugye egy fiatal elsögenerációs társaságot még a rendszerváltás után nem sokkal bevittek a Csíkszeredai kollégiumba, s azok szépen fölnöttek és azok között sok egészen kitünö fiatal értelmiségi lett. Megpróbáltam öket helyzetbe hozni, tehát, hogy konferencián
\end{abstract}

\footnotetext{
${ }^{54}$ Religion is religion, you know, we believe in God, and I think the important is God and not the language in which we pray, and I would not stress masses so much. The Hungarian masses, I would not stress so much because if so many contrast, from the side of priests we confront this, and the people are not mature enough for it. First people should be prepared to truly ask for the Hungarian mass. To understand, and then would ask for it. If they would understand and see the purpose of it, because if is Romanian, if is Hungarian we say that praying to God is possible in any language, then I don't know why it needs to be forced so much. And that too, if I know it well, there never were Hungarian masses in Moldova. It was different when there were Hungarian priests, because they spoke in Hungarian but masses were in latin then in Romanian. And then we say to reintroduce the Hungarian masses. I am not against it, if succeds somewhere I am happy for it, because it has no disadvantage, but to make camps in Moldova, to split the village in two, to have the people yelling to each other, or fighting ... it doesn't worth it. It doesn't worth it, is not a crusade, in todays world it doesn't worth it. Ok, there is not abig problem with religion either, it is not a bg fight, Hungarians are not involved with great power, but if there is any power it should be focused on something else, leave this in peace and pray decently. And then if we are such friends, then the Hungarian priest can be there too, in our houses too ... if I am there, I call my relatives over and pray together with the Hungarian priest, but not like now, taking into a fight.
} 
elöadhassanak, hogy tessék lám vannak már változások. ${ }^{, 55}$ (older than 51 current leader living in Hungary)

Another aspect of the Csángó matter is publication and book editing - novels, poems, tales, albums, etc. - written by Csángós. As Laura Iancu said about a photo album edited by her:

„,vannak ott szép képek a lakodalom meg az élet ünnepi része, de nem éreztem arányosnak egyrészt, másrészt külsö-, és belsőszem; miért nem foglalkozunk azzal, hogy a csángók mit tartanak érdemlegesnek megörökitésre. Mert az, hogy csángólakodalom, annak oka van, akkor azonnal átöltözik, tisztaruhát vesz, az, hogy szennyes ruhába, munkafolyamatok során, nem az idilli én kerül lefotózásra, ez egy teljesen új jelenség, és hát nem utolsó sorban a magyarországi fotósok szoktatták rá arra a csángókat, hogy nem mindjárt kell beöltözni, hogyha fotózva van, mert ez így érdekes. És akkor rádöbbent a világ, hogy ilyenek is a csángók nem csak olyanok. ${ }^{, 56}$

One necessity of the Csángó matter and the need for people to be active in it, is sustained by the fact that, there is no written history not even sources that are collected and written by Csángós. There are several publications, journals focusing on this part of Romania and its habitants, but these publications were published by travelers and foreign scientists. There is a lack of publications that present the way how Csángós see themselves. Many scientific works published by young Csángós seeks to fill this gap.

„Ha belegondolunk, csángók által megirt csángók történelme sincs. Sok próbálkozás volt, persze Magyarországiak meg Erdélyiek részéröl, de az, hogy a csángók annyira öntudatára ébredjenek, hogy kialakuljon az a szélesebb réteg, aki azt mondja, hogy leülünk, és akkor megtudjuk a csángó történelmet, vagy a csángó nép múltját. Lehet, hogy bátortalanok vagyunk, lehet még nem mertünk lépni, mert a gondolat hogy egy csángó szótárt megirni már megszületett bennünk. Ez egy nagyon kemény kihivás lenne, mert ugye minden faluban mást jelent egy szó, vagy nem éppen ugyanazt, hanem árnyalatai vannak, mindez a csángó nyelvnek a gyengéje vagy a nehézsége. Minden faluban élni kell két három évet, vagy minden faluból ki kell kerüljön egy két három ilyen csángó értelmiség, aki, úgy mélyen tudja a falujának a nyelvét. Egy másik ötlet volt, hogy irjunk csángó történelemkönyvet ...

\footnotetext{
${ }^{55}$ What is obvious is that the doctrine that Csángós are vulnerable because they don't have an intellectual strata started to change in 2000 , because the a young first generation group was taken shortly after the regime change to college in Miercurea Ciuc, and they nicely grow up there and among them there are several very exceptional intellectuals. I've tried to create opportunities for them, so, to present on conferences, so it can be seen that there are changes.

${ }^{56}$ there are nice pictures about weddings and the festive aspects of life, but I did not feel it in proportion on one hand, on the other hand the outsider, and the insider eye, why aren't we dealing with what the Csángós consider worthy to immortalize. Because the Csángó wedding is with cause, the instantly changes, take clean clothes, the dirty clothes, during works is not the idyllic me that gets to be photographed, this is a totally new phenomenon, and not the least that Hungarian photographers habituated Csángó, that there is no need to instantly change clthes as one is photographed, because this is how it is interesting. And then the world realized that Csángós are like this as well, not only like that.
} 
csak kevés ember van. Ez egy többemberes, nagy munka, nagy kutatást igényel. Nem elég kimenni a Széchenyi könyvtárba és elöszedni, hogy mit irt Mikecs, Karácsony János, Aigner Károly vagy nem tudom ki, hanem be kéne menni Moldvába be kéne menni az ottani plébániákra, akol ugye vezették a csángók szellemi életét, a csángókról a statisztikákat. Ugyan nem sokat mondanak az ottani egyházi statisztikák, de mégiscsak forrásként fel kell használni. Ki kéne menni a Vatikánba, az ottani levéltárba ... Tehát nagyon kemény, nagy kutatási munkát igényelne egy ilyen münek a megirása, és ennek még nem látjuk, hogy mikor fog ez megvalósulni, vagy mikor nem. Én nagyon remélem, hogy mondjuk egy generáció kérdése csak, 15-20 évbe gondolkodok és hátha-hátha lesz annyi bátorsága a mostani csángó értelmiségieknek, hogy ... ${ }^{57}$ (younger than 35 employee living in Hungary)

Another important aspect of the Csángó matter - still related to the scientific research - is the editing and publishing of the Csángó Tükör (Csángó Mirror) in Budapest. The journal was entirely written, edited and published by young intellectual Csángós, who published articles in their fields: history, linguistics, literature, ethnography. One of the founding members rememberes that as a good idea it was, it was just as difficult to get together and to motivate the graduated, educated Csángós to write, to think, to dare to express their opinions. Other two journals are published which focus on the Csángó culture. A bilingual journal published by Duma András in Moldova, entitled Mi magunkról-Noi despre noi (About ourselves), the other is edited in Széklerland, is called Moldvai Magyarság (Hungarians from Moldova).

The Csángó matter has more pragmatic aspects as well, such as organizing trips from and to Moldova and local tourism. While the first one is mostly for children enrolled in the Hungarian education, and the goal is to bring them to Hungary, the second one is mostly organizing the accommodation of the godparents and guests interested in the Csángó culture. Both these aspects are supported entirely or partially by the Hungarian government, or there are calls for funds from Hungary. Applying for

\footnotetext{
${ }^{57}$ If we think through it, there is no history of Csángós written by Csángós. There were many attempts, by Hungarians and Transylvanians, but to awake Csángós to the selfconsciousness, that to develop a wider strata who could say, that sit down and figure out thehistory of csángós, or the past of Csángó people. We might be diffident, maybe we are afraid to take a step, because the idea of wriring a csángó dictionary already borned. This is a really though challenge, because in every village a word has a different meaning, or doesn't mean the same thing, but it has nuances, this is the weaknes or the difficulty of the Csángó language. Should live in all villages for two three years, or from each village should find two three intellectuals, who, deeply knows the language of his/her village. Another idea was to write a Csángó history book ... there aren't enough people. This a work, that recquires several men, great work and great investigation. It is not enough to go to the Széchenyi library and take over what Mikecs, Karácsony János and Aigner Károly or others wrote, but should go to Moldova, to the churches from there, where the spiritual life of Csángós, statistics about Csángós were carried. Although clerical statistics from there aren't saying to much, yet they still should be used as source. Should go to the archives of Vatican too. ... So, writing such a work, would recquire very strong, heavy investigation work, and we can't see, when this will be realized or not. And I really hope that is only the question of one generation, I think in about 15-20 years and maybe-maybe the current Csángó intellectual will have the courage to ...
} 
these funds has at least two difficulties, one collaboration with others is difficult either because competition is greater than the intent of collaboration, second is the ability of providing the proportion of funding asked by the announcer. Accurate accounting also encounters difficulties.

„Ha pedig fözne édesanyám nekik ételt egy hétig azt, hogy számoljam el? Édesanyám nem ad számlát, nem az a foglalkazása. Levágtuk a tehenet, hogy legyen miböl fözni és akkor miböl vetted a húst, hát ebböl a pénzböl, és akkor húsért számlát tudsz-e adni, és hát nem tudok... Mindent úgy kellett volna, hogy megveszem az aláhaktól, a románoktól Bákóból, akkor minden pénz elment és nem segitettem azzal édesanyámon sem, nem segitettem azzal a faluban egy gazdának sem. "58 (36-50 years old employee living in Moldova)

The yearly organized Csángó Ball in Budapest is an important event of the Csángó matter. It brings together politicians, social scientists, representatives of organizations and foundations, representatives of the Csángó culture, singers, dancers, artists, writers, photographers, etc.; all those who consider the Csángó culture a heritage that should be, has to be preserved. In the organization of the Ball, beside the representatives of the Hungarian government and organizations, several Csángós living in Hungary have active roles too. In the "Táncház mozgalom” in Hungary, the Csángó folk culture had and still has a great prestige. Several bands were formed in Hungary who play Csángó music or some interpretation of it. These groups are also present in the Csángó Ball and in another festival also organized in Hungary, in Jászberény. While the Ball is a good "advertisement" of the Csángó culture, some think that it should be organized in Moldova for those Csángós who live in Moldova.

\footnotetext{
“Vótam a csángó fesztiválon, de ott annyi sokan vannak ameljikek nem is csángók. Jönnek oljanok zenélnek ott, s pont a Moldvait mutassák bé. Miért mutassák bé a moldvait mikor én itt vagyok. Ott voltunk Hodoroggal ketten és nem kellett zenélni. Eljött egy együttes innen eljött egy másik együttes onnan ... Ha egyszer csángó fesztivál lesz, ha csángó bál lesz akkor mutasd be igazából a csángókat, kihivni ugy engemet oda hogy kiszurja a szememet $10000 \mathrm{Ft}$-t, elmegyek négy napot hiányzok hazulról, egy este fellépjek oda s akkor a többit jönnek nem tudom miljen zenekarok kik honnan. Én hiszem hogy kell a közönségnek valamit bemutatni ... mutassanak valamit be a csángók is, nem csak négy
}

\footnotetext{
${ }^{58}$ And if my mother would cook for them for a week, how could I account with that? My mother doesn't give an invoice, is not her job. We butchered a cow, so we so have what to cook, and then whereof you bought the meat, and then can you give an invoice for the meat, and then I can't. ... I should have buy everything from Romanians, from Romanians from Bacau, and then all the money woul've been gone, and I would not helped my mother or any farmer from the village either.
} 
táncot bemutatnak a Somoskaiak, három csárdást a Gyimesieks akkor nem tudom miljen

faluból még. ${ }^{, 59}$ (older than 51 employee living in Moldova)

The most frequent argument is that this way the Csángó Ball is organized for Hungarians mostly from Budapest and Csángós have no or little chance to attend. Only those Csángós from Moldova are participating who are invited, guests and/or are performers in the program.

No wonder that some see the Csángó matter as a business recognized not only by Csángós involved but by Hungarians from Hungary and Transylvania as well. Activity in the Csángó matter can be used as a capital not only in cultural and economic but in political fields as well.

„A csángó ügy, most biznisz ügy, nagyon, nagyon le van züllesztve, morálisan és mindenféle más szempontból is. ${ }^{" 60}$ (older than 51 former leader living in Hungary)

Some Csángós active in the Csángó matter think that they are not the one to be accused of conducting ethno business. One interviewee told his experiences of Hungarians doing Csángó ethno business. He thinks that many are interested in the Csángó culture only until they can build social and/or economic capital from it.

"Hát igen s akkor ök mindenhova mennek s ha engemet vaegyszer megkell hivjanak valahova akkor olyan sok pénz, 20000Ft olyan sok pénz ki oda-vissza, hogy kell fizetni azt az útiköltséget. Náluk egy zenész igazából egy este nem zenél 10000Ft alatt. Na mindegy csak ez nekem egy kicsit nem esik jól mikor egy idejig szeretik, csinálták, felvettek mindenfélét s aztán ennyi jól volt nekik. Béjönnek ide is ugye, béjö ide és tanissa az én dalaimat? Hát micsoda dolog az? ... de még az se lenne semmi, de tanítná rendesen, de azt se csinálja meg rendesen. Elrontották az egész zenét, hogy megkell gondolkozzak mikor kimegyek oda, pedig azok akik fujják ezeket a dalokat kicsi gyerekek voltak mikor jöttek elöször táborba s azután lesegettek mindig ingemet s tanultak. Most megkell hallgassam mit is akar funni, mi ez, annyira elrontották. "61 (older than 51 employee living in Moldova)

\footnotetext{
${ }^{59}$ I've been in the Csángó Festival, but there were so many who are not even Csángó. many are coming to play music there, and they are presenting precisely the moldvaian. Why are they presenting the moldavian if I am there. We were there with Hodorog, and we didn't had to play. A band came from here, the other from there ... If there will be once a Csángó festival, a Csángó Ball, than present truly Csángós, to call me out there so they can humiliate me with $10.000 \mathrm{Ft}$, I go there, I am missing from home for four days, to be on stage and then the rest, are coming I don't know what other bands from somewhere. I do believ that somethings needs to be presented to the audience ... Csángsó should present something, not that for dances are presented by those from Somusca, three are presented by those from Ghimes, and then from I don't know from which other village.

${ }^{60}$ The Csángó matter, now is a business matter, is very very disrupted, morally and in all other aspects as well.

${ }^{61}$ Well yes, and then they go everwhere and if I am supposed to be invited occasionally, such a great amounf od money, $20.000 \mathrm{ft}$ (about 70 EUR) such a lot of money that they should pay for transportation there and back. Here a musician doesn"t play for less than 10.000 FT per night. Anyway, just that this
} 
Strongest opposition in the "Csángó business" is toward those who seem to prosper materially since they are active in the matter. Conflict is very much present in the Csángó matter, among institutions, organizations and individuals as well.

„... egyik szervezet sincs jóban a másikkal. Ezt sajnálom. A csángó szervezet az nem igaz, hogy ö képviseli a csángókat. Nem tudja. Még ha lenne es egy nagyobb egyesület ameljikbe belép mindenik szervezet, mint egy fórum, egy kemény federáció, ameljikben benne van mindenik szervezet és alapitvány, ... akkor is mi nem képviseljük teljesen a csángókat, mert ott van az egyház, ami egyelöre semmiképpen nem áll mellénk. Nem áll mellénk. Azt nem mondhatja senki, hogy ,én képviselem a csángókat”, te képviseled a tagjaidat, azokat az értékeket, melyeket a tagjaid vallanak és azt a területet, amit te akarsz megvalósitani. ... nem is az a lényeg, hogy én képviselem a csángókat. Én nem képviselem a csángókat. Én próbálok ott tenni valamit. ${ }^{, 62}$ (older than 51 current leader living in Moldova)

Being a business or not, or accumulating capital by being active in the matter in it, there is one important question on whose responsibility is the Csango matter. There is no consensus regarding whose duty or concern is (or should) be the Csángó matter. The Hungarian teaching in Moldova should be part of the Romanian educational system, or should be kept as it is, organized by foundations and supporters? Is the Csángó matter a Romanian minority issue, or a Hungarian Diaspora topic or maybe it should be of European Union concern?!

Regardless of geographic location all Csángós active in the Csángó matter name as a reason why they are involved in this cause the fact that they feel as a duty toward their community, they feel that their actions are beneficial to the community and Csángós in general. This is even more pronounced for those who are settled in Hungary.

„A közös érdek sem annyira erös ... elégedetlen vagyok ... mert azt gondoltam, ha 90 után kinyilt egy lehetöség, akkor ha mondjuk a saját életemet realizálom, mindenképpen ott legyen az, hogy a közösségünkét is. Hogyha valamit teszek, akkor az szolgálja a közösséget is, mert ha nem akkor meg miért volt változás. Kitöl várunk változást? Én amikor az

doesn't fell good, when for a while they liked it, they were making it, recording everything and then that was enough for them. They are come in here too, come in and teaches my songs? What kind of thing is that? ... but even that won't be a problem, but at least would've teach properly, but he/ doesn't do that properly either.They've ruined the entire music, that I have to think when I go out there, although those who are playing these songs were small children when they came for the first time to camps, and they were peeking at me and learn it. Now I have to listen what exactly wants to play, what is this, that much they have ruined it.

${ }^{62}$ no organization is in good relation with the other. I am sorry for that. It is not true that the Csángó organization (the MCSMSZ) represents Csángós. It can't. If it would exist a greater association in which all organization would enter, like a forum, a strong federadion, in which all organizations and foundations are present, ... even then we would not represent Csángós totally, because there is the church which at this point is not aour side. Is not on our side. No one can say, that "I represent Csángós", you represent your members, those values that your member testify and those fields that you want to realize. ... it is not even the point that I represent Csángós. I don’t represent Csángós. I try to do something there. 
állampolgárságot megkaptam végig zokogtam, olyan háború lett bennem mintha elárultam volna az otthoniakat, hogy én megkaptam s akkor mi lesz a többivel?! ... hogyis mondjam, nem akarom verni a mellemet, hogy fáj vagy ... de, úgy érzem, hogy nem teszünk eleget, nem az otthoniakért, mert ne mindenki csak a családjára vigyázzon, vagy csinálja amit tud, hanem úgy az egész csángóságért."

Interviewees agree that beside national or international aids and measures, local activity is vital; local leaders - political, cultural, economic support - should get involved rather than wait for, or rely on foreign help.

"Egyszer kellene a segitség innen tölünk a faluból. Egyszer ez nagyon fontos lenne, hogy a kultúra megmaradjon itt nálunk segéljenek ők is ebbe, a polgármester például. ... Egyszer innen kellene segitség mert ugye itt vagyunk, itt születtünk, itt maradtunk. A másik, ha valaki lenne aki szponzóráljon vagy valami segitséget adjon küntröl az is jól jönne. Én mondtam, én ezt nem Jászberényben tanultam, nem Pesten tanultam, nem Erdélyben tanultam hanem itt. Itt nem is csinálják, ha mük nem leszünk lehet nem is fogják csinálni. ",64 (older than 51 employee living in Moldova)

Foreign aid helps the matter but cultural heritage first of all needs to be kept, maintained and practiced in its original location. While some aspects of the Csángó matter seem to be very elaborated and involve many people and institutions, other aspects are present mostly or only by name. From the 9 points named by Tytti Isohookana-Asunmaa - ex. creating possibilities for the education in the mother tongue, celebrating masses in Csángó language (not Hungarian, but Csángó), shaping programs for the maintaining of the Csángó culture, providing access to mass communication, creating small and medium enterprises, research (Isohookana-Asunmaa, 2001) - there are quite a few deficits. There are no Hungarian schools in Moldova, masses are celebrated in Romanian, the rate of enterprises in very low, there are no Hungarian cultural institutions, villages have just started to be connected to the internet, etc.

\footnotetext{
${ }^{63}$ The common will is not so strong either ... I am dissatisfied ... because I thought that if after 90 an opportunity was opened, and if let's say I realize my life, necessarily has to be there to relize our communities as well. If I do something that should serve the community too, because if not than what was the (regime)change for. From whom are we expecting to make a difference? When I received the citizenship I was crying all along, such a war was in me like I betrayed those from home, that I received it and then what happens with the others?! ... how should I put it, I don't want to boast that it hurts me ... but I feel, that we are not doing enough,not for those who are at home, because taking care only about his/her family, doing what they can but in general for al Csángós.

${ }^{64}$ First of all help should come from here, from the village. First this would be very important, they should help so that culture remains here, the mayor for example. ... First help should come from here, because we are here, we were borned here, we remain here. The other, if it would be someone to sponsor or to give some help from outside, that would be good too. I said, that I did not leened this in Jászberény, I did not lerned that in Budapest, not lerned it in Transylvania, but here. Noone does it here, if we will be gone possibly they won't do it.
} 
"Ha nekem valaki mondja a 90-es évek elején, hogy 15 - 20 év múlva itt fog tartani ... nincs egy magyar müvelödési ház Bákóban ... akkor biztos nem hiszem el. Nem hogy nem hiszem el, fel lettem volna háborodva." 65 (older than 51 current leader living in Hungary)

"Hátha igazán lenne erre lehetöség, inkább a felnöttekkel foglalkoznék, szakmát adnék a kezükbe, mert egy felnöttnek sincs igazából szakmája. Úgy lehet a felnötteknek szakmát adni, hogy már egyböl ö vállalkozást indít, olyant tanitani, amit tudunk, hogy esetleg a falvainkban hiányzik. ",66 (36-50 years old employee living in Moldova)

It is important to introduce the Csángó matter - especially education - into the Romanian national political and European level as well. After the regime change Csángós were always a focus of interest of politicians (ex. Zsolt Németh, László Tőkés) from Hungary and Romania. Still, beside individual involvement there is need for strategic planning including institutionalization and involvement of national capitals.

The Csángó matter has cultural, social and political aspects, and involves many individuals and organizations. Elite identification should be done by the community itself and elites should avow each other. In order to characterize the Csángó elite and their concerns and opinions, narrations were grouped around the following topics: identity, Romanian-Hungarian cooperation or conflicts, the role of the Catholic Church and the dichotomy of learning -guest working.

A first characteristic of the Csángó elite needed to be discussed is given by ethnic (self)identification. Elites are seen as role-models, their identification might influence the identity of others as well. Seeing that admitting Hungarian identity is not a thing to be ashamed of, or something that one has to hide from the majoritarian society might encourage others as well to undertake their minority identity. Second characteristic is originating from the first one; the Hungarian-Romanian problematic is very present in the everyday life of the community. The Catholic Church is one of the most important institutions in the Csángó culture - if not the most important - and being in good or at least neutral relation with its representatives, the priests is vital. For many years the church was one of the most important organization through which assimilation was conducted in Catholic villages in Moldova. In 1915 Hungarians from Lujzikalagor asked for permission to use their mother tongue in the church Camili bishop answered:

\footnotetext{
${ }^{65}$ If someone would have told me at the beginning of the 90's that after 15-20 years things would stand here ... there isn't any Hungarian cultural house in Bacau ... then I am sure I wouldn't believe it. Not that I wouldn't believe, I would've been outraged.

${ }^{66}$ If there would be any possibility, I would rather deal with adults, I would give them a profession, because adults have no profession. Giving a profession to adults is possible if one can instantly start an enterprise, to teach something about what we know that is missing.
} 
"A kérvényezöknek tudniuk kellene, hogy Romániában a nép nyelve a roman, és nem is lehet más. Saját nemzete elleni jogatlanság, és szégyen volna a saját személyére nézve, ha ebben a hazában valaki egy idegen nyelven beszélne, például magyarul."67 (Domokos, 1979:94-95)

The attitude of the leaders of the Catholic Church in Moldova is still similar. As Petru Gherghel $^{68}$ wrote in his answer to the letter of László Tökés ${ }^{69}$, there are no objections against Hungarian classes they can be held just like other language -classes:

“...nimeni nu se împotriveşte orei de limbă maghiară în şcoală, într-un cadru legal, organizat, dacă acest lucru se cere şi se impune, aşa cum nu se împotriveşte nimeni desfăşurării orelor de limbă engleză, franceză, germană, italiană etc. Programa şcolară se intocmeşte în conformitate cu normele de învățământ şi necesitățile reale ale şcolii şi comunității. "70

Acts seen by Tökés as a hostile campaign is nothing but the carrying worry of the priest, watching over his parishioners, only warning the community about those who are holding the Hungarian classes and raise suspicions:

\begin{abstract}
„Cu privire la atitudinea parohului de Nicoreşti şi a altor preoți, la care dumneavoastră faceți referință, nu s-a verificat "o adevărată campanie duşmănoasă față de educația în limba maghiară". Mai degrabă se poate constata o grijă pastorală pe care preotul paroh o desfăşoară în parohia încredințată, pentru a veghea la liniştea, la moralitatea şi la credința enoriaşilor care $\hat{i}$ sunt încredințați.

Din analiza făcută în parohia menționată $n u$ a rezultat că părintele ar fi fost împotriva invățării vreunei limbi, cu atât mai puțin împotriva învățării limbii maghiare, mai ales că multe persoane din localitate lucrează în Ungaria. Nici credincioşii, întrebați fiind, nu au ințeles că parohul ar fi luat atitudine împotriva limbii, ci i-a avertizat asupra modului de lucru al celor două persoane venite în sat, care au trezit şi trezesc suspiciuni. ,"7l
\end{abstract}

\footnotetext{
67 "The petitioners should know that the language of the people from Romania is Romanian, and it can not be anything else. It is against the laws of their own nation and a shame to their own person if in this country someone would speak in a different language for example in Hungarian"

${ }^{68}$ Catholic bishop of Iaşi

${ }^{69}$ previous reformed bishop of Transylvania, and since 2010 Vice-President of the European Parliament

$70 \mathrm{http}: / /$ ro.csango.ro/index.php?page=rasp_gherghel downloaded in $04-04-2011, \ldots$ no one opposes having Hungarian language classes in school, in a legal, organized framework, if this thing is requested and inflicted, just like no one opposes carrying English, French, German, Italian, etc. Classes. The curriculum is drawn up in accordance with the norms of the education and the real need of the school and community."

71 http://ro.csango.ro/index.php?page=rasp_gherghel downloaded in 04-04-2011. „Regarding the attitutude of vicar of Nicoreşti and other priestim to whom you make reference, did not verified ,a real hostile campaign against the education in Hungarian language". Rather it can be seen a pastoral care conducted by the parish priest in the entrusted parish, to ensure the peace, the morality and the faith of parishioners entrusted to him.

From analysis made in the mentioned parish had not demonstrated that the priest would have been agains learning any language, much less against learning Hungarian language, especially that many people from
} 
Discussing Romanian-Hungarian aspects of the Csángó elite is inseparable from presenting the conflicts among the two groups and to reflect on the role of the Catholic Church in the everyday life of Csángós, and in the work of elites. Learning and guest working experiences - and migration as such - strongly influence all these aspects. Like in any other topic that refers to representation, all involved, have a theory about what is good or bad for the community they represent, and people tend to see as a wright or the only good solution the one they apply or sustain and all others mistaken. With certain ides or theories specific positions and appreciations of the society goes along and as such competition among participants of the Csángó matter is inevitable. Understanding this, clears the lack or low level of collaboration among organizations, and the conflict among key figures of the Csángó matter.

the locality are working in Hungary. Neither the believers, being asked, did not understand that the pastor had taken a stand against the laguage, instead worned them regarding the way of working of those two people who came to the village, who aroused and awake suspicions. 


\section{Description of the Csángó elite based on interviews}

\section{Motto:}

“Kicsit furcsán hangzik, hogy van egy csángó elit, mondjuk Moldvában, és van egy csángó elit, mondjuk Budapesten, csak az egyik ténylegesen a csángók megitélésben csángó elit, a másik pedig a mafgyarországi magyarok számára csángó elit. Tehát lehet egy ilyen eltolódás, és egy ilyen párhuzam, mint mondjuk a táncban is. Van egy tánc, amit másképp járnak Moldvába, és elmész Magyarországon egy táncházba, és úgy gondolod, hogy ez nem az a tánc? Lehet ilyen az elittel is?!"72

(younger than 35 former leader living in Moldova)

The Csángó elite - which according to the literature is missing - not only developed in the past couple years but seemingly geographically is twofolded and in this stands one of the challenges of the csángó elite investigation, as it was accurately formulated in the Motto of this chapter by a member of the elite itself. The presentation of the most important characteristics and concerns of the elite - using first of all the qualitative data received from interviews - is preceded by a diagram containing the percentages in which a specific characteristic was named as required in order to see someone as elite and a table presenting the demographic characteristics of respondents.

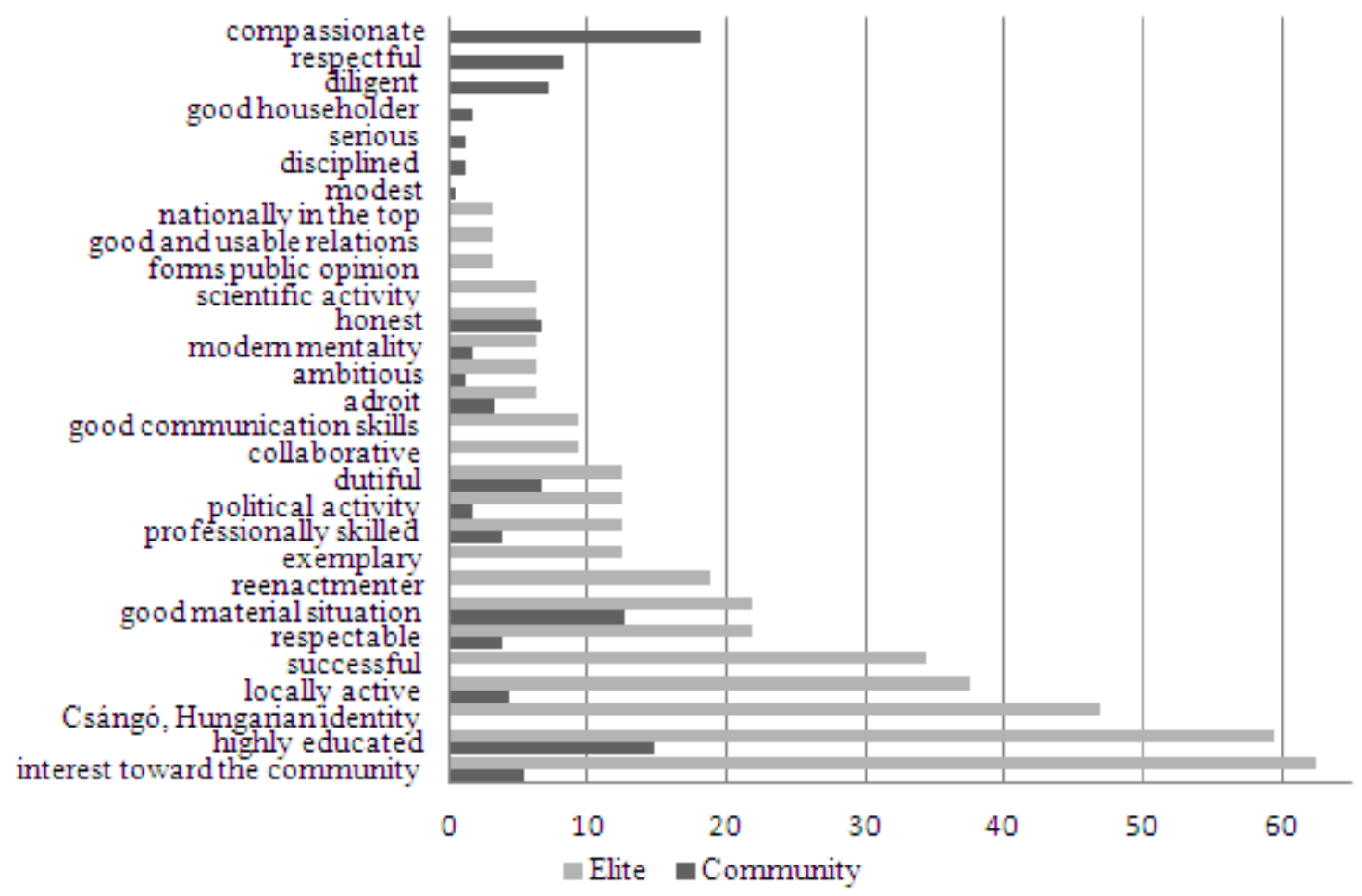

Figure 5: Elite characteristics expected by the community and the elite itself

It can be seen that there are characteristics that appear among the expectations of elites and the community as well, just as there are characteristics expected only by elites

\footnotetext{
72 "It sounds a bit strange that there is a Csángó elite let's say in Moldova, and there is a Csángó elite let's say in Budapest, only one is csángó elite in the perception of csángós and the other is csángó elite for Hungarians from Hungary. Is such a shift, such an analogy possible, like in dance. There's a dance, you dance differently in Moldova, and if you go to a tanchaz in Hungary you think is this the same dance? Can this happen in the case of the elite too?!"
} 
or only by the community. Education plays a more important role for elites than in the eyes of the community. Being respectful and compassionate are some of those characteristics that were named by the community only. At the same time expectations like being present in the national elite or having a good social network and social capital was named only by elites. As a basic comparison it can be said that for the community the humane characteristics "how well educated and respectful" he/she is counts more, while for the elite characteristics that can be used in serving and representing Csángós and the community matter.

\begin{tabular}{|c|c|c|c|c|}
\hline & \multicolumn{3}{|c|}{ Interview } & Questionnaire \\
\hline & $\begin{array}{l}\text { Prestige } \\
\text { elite }^{73} \\
(\mathrm{~N}=29)\end{array}$ & $\begin{array}{l}\text { Elite } \\
(\mathrm{N}=28)\end{array}$ & $\begin{array}{l}\text { Total } \\
(N=57)\end{array}$ & $\begin{array}{l}\text { Total } \\
(N=182)\end{array}$ \\
\hline \multicolumn{4}{|l|}{ Gender } & \\
\hline Male & 22 & 16 & 38 & 149 \\
\hline Female & 7 & 12 & 19 & 33 \\
\hline \multicolumn{5}{|l|}{ Age } \\
\hline Below 40 & 18 & 22 & 40 & 67 \\
\hline Above 41 & 10 & 7 & 17 & 115 \\
\hline \multicolumn{4}{|l|}{ Location } & \\
\hline Romania & 13 & 16 & 29 & 182 \\
\hline Hungary & 16 & 12 & 28 & 0 \\
\hline \multicolumn{4}{|l|}{ Degree } & \\
\hline Don't know & 0 & 5 & 5 & 0 \\
\hline Less than professional & 0 & 0 & 0 & 114 \\
\hline Baccalaureate or Profession & 7 & 4 & 11 & 66 \\
\hline College or University & 22 & 19 & 41 & 2 \\
\hline \multicolumn{4}{|l|}{ Language of education } & \\
\hline Only Romanian & 4 & 7 & 11 & 178 \\
\hline Romanian and Hungarian & 24 & 19 & 43 & 2 \\
\hline Only Hungarian & 1 & 2 & 3 & 2 \\
\hline \multicolumn{4}{|c|}{ Social activity related to Csángó topics } & \\
\hline $\begin{array}{l}\text { Leaders of foundations, } \\
\text { organizations }\end{array}$ & 12 & 3 & 15 & $N D$ \\
\hline Organizing cultural events & 6 & 6 & 12 & $N D$ \\
\hline $\begin{array}{l}\text { Participating to scientific } \\
\text { debates }\end{array}$ & 6 & 2 & 8 & $N D$ \\
\hline $\begin{array}{l}\text { Participating to political } \\
\text { meetings }\end{array}$ & 5 & 1 & 6 & $N D$ \\
\hline International advocacy & 18 & 5 & 23 & $N D$ \\
\hline
\end{tabular}

\section{Table 6: Demographic characteristics of respondent}

The elite formed by the snowball sample has members who are locally in Moldova and/or in Hungary, and they are mostly members of the young generation. 40 out of 57

\footnotetext{
${ }^{73}$ Those are considered as prestige elites who received more than four nominations
} 
people are younger than 40 years old, and 38 are male. The majority - 43 people received education in both Hungarian and Romanian language, meaning that either they were children when the Magyar Népi Szövetség initiated Hungarian schools in Moldova, either they were enrolled to the Hungarian teaching of Csángós in Széklerland or graduated from a Hungarian university. From the 57 Csángós named as elite 15 are leaders of foundations or organizations focusing on the Csángó matter, 12 are organizing cultural events on a regular basis, while 8 people are interested in the scientific aspects of the Csángó matter, they are participating in scientific debates, conferences and are publishing scientific works, journal articles and books; 6 are active in political meetings. International advocacy of the Csángó matter is done by 23 of the nominated ones.

The following network ${ }^{74}$ shows the kinship relations among the members of the elite. Several members of the Csángó elite are - by birth or through marriage - related.
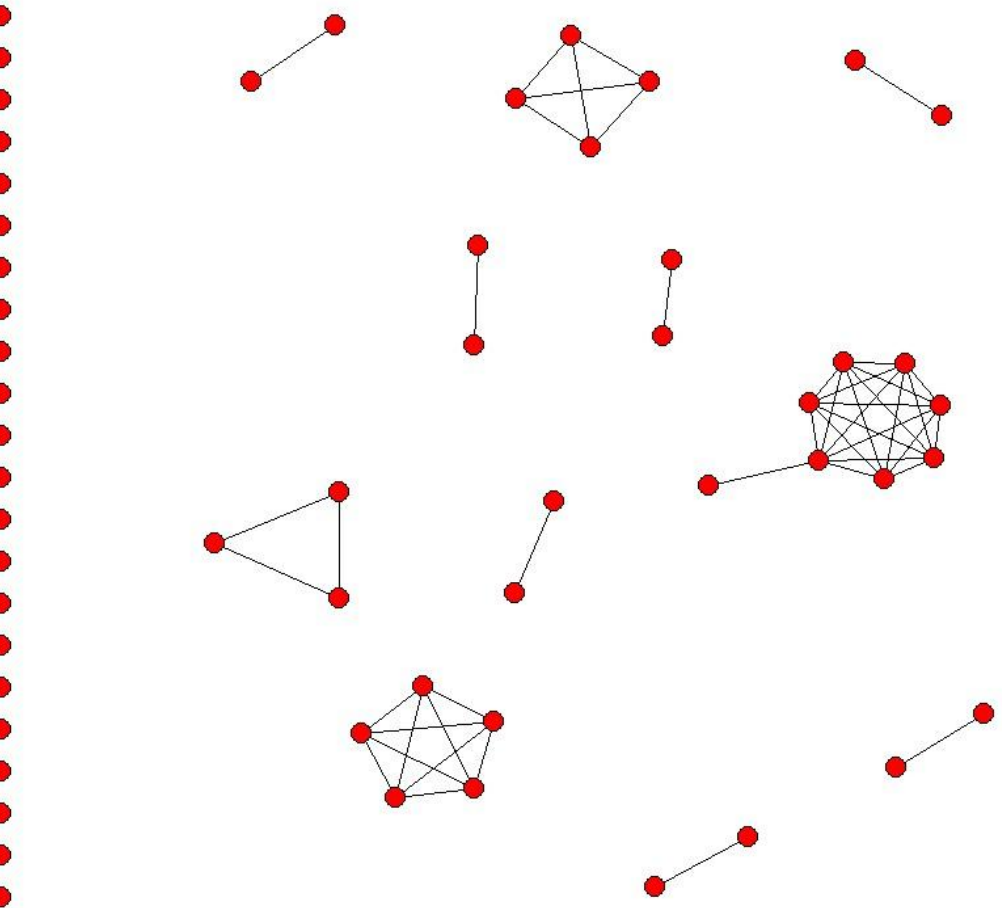

Figure 6: Kinship relations among the members of the Csángó elite

Member recruitment is often realized through kinship relations. If someone enrolls in a Transylvanian or Hungarian education institution is likely that his/her siblings will follow the same path. Activity in the duty of the Csángó matter is also something that involves several members of the same family. ${ }^{75}$.

\footnotetext{
${ }^{74}$ The network shows only the strong ties, brothers, marital and parent-children relations were included only.

${ }^{75}$ The relatively high number of kinship relations might be due to the inaccuracy of snowball sampling, namely that people are more likely to name someone as important from their own, close social circle.
} 


\subsection{Is there a Csángó elite? How can we characterize them?}

By taking the elite concept at its widest meaning and by looking at any society that might seem homogeneous at first sight, we can see that stratification and differentiation always exists. Csángó society and Csángó villages are no exception either. One could argue that only this is not enough, and that in order to speak about elites, recognition, status, prestige, power, wealth, or in other word capital - material, human, social, etc - or at least some of this characteristics are required.

Respondents seem to agree that the "Csángó elite" lives its early childhood and future results are expected, yet no one could decline those results that are shown up to now. We just have to think to Mária Petrás (Dioszén), and her worldwide known statues and handicrafts, art compositions exposed in several countries, folk singers like Ilona Nyisztor, or social scientists, historians, ethnographers, or to the leaders of the MCSMSZ who went from the Romanian parliament to Hungary and to Brussels as well, asking for permission to learn and have masses in Hungarian language. We can also mention well known Csángó writers, such as Demeter Lakatos, who wrote his poems about the hard, yet beautiful life of his people and their belonging to Hungary, in Csángó dialect, but with Romanian orthography. He was persecuted and threatened by the Romanian authorities for his Hungarian feelings. His poems were hidden in a sack in Moldova, and later printed in Switzerland. Another writer, Márton Demse studied in Transylvania, and now lives in Budapest, or András Duma who lives in Moldova and is the head of the Szeret-Klézse Foundation, or from the younger generation Laura Iancu, who publishes poems, tales and scientific articles as well.

An important writing that can be usefully used in the case of Csángó elites is the observation of Herzfeld, who noted that for elites one channel of preserving their position and power is by "monumentalizing the past" (Herzfeld, 2000:234) The following pages contain a presentation of the Csángó elite and their major interests and conflicts. Similarly to Herzfeld's observation members of the Csángó elite are using the past and cultural element of the past as capital, as legitimation forms.

Even in the most severe meaning of the elite term, the Csángó elite wins validity.

„Egy egész életen át a magyar nyelvről pofáztam mindenfelé és a magyarságról. Hát ugye, hogy ide jöttem 90 nem 2001-be a Magyar Kultúra Alapitvány, Csengei Dénes ezüst fokozatát kaptam meg, irodalmi díj, akkor ezelött vagy 3 évvel a Petöfi Sándor sajtószabadság dijat, akkor most jött egy jó két héttel a Magyar Szellemi Védegylet a Rendületlenül címü diplomát adták, a magyarságért tett munkáimért. Hát én különösebben 
egyikre se szolgáltam rá, de amit tettem, amit írtam életembe csak azért tettem, mert ösztönböl jött, hogy valahogy a csángóság valahol nyomon maradjon, mert hovatovább pusztulunk, beolvadunk. Hiába nö ki a csángók közül értelmiségi, mert nem tud meglenni, mert az össznép nem akarja a magyart. Mert miért? Mert van a természetes és jogos gondolkodás. Hiába, jó, hogy a csángó magyarul tud, jó, az kitünö dolog, hogy az anyanyelve megmaradjon, de a magyar nyelvet, ha csak azt tudja, nem tud sehol érvényesülni. Ha bemegy a városba, kiment a faluból, kiment a rezervátumból a nagyvilágba, ott már elvész. Ott a csángónak csak akkor van létjogosultsága és ereje, ha mind a két nyelvet tökéletesen beszéli. ",76 (older than 51 employee living in Hungary)

Csángós just like other minorities had some representatives in the cultural sphere, who against difficulties assume their identity, even if they were persecuted for it. This is true for the communist regime as well, yet the number of these representatives is small.

"Sokat irtam, a Korunknak, az Igaz Szónak, jöttem Magyarországra is sokszor, és jöttek hozzám külföldiek, s végül a Securitaténak a látószögébe kerültem. Behivtak egyszer és azt mondták, hogy túlságosan barátkozom a külföldiekkel. Azt nem szabad, az hazaárulás. Ha jöttem Pestre akkor mindig ahogy hazamentem már ki kellett pakolni, meg kellett mondani, hogy kinél jártam, jelentést kellett tennem. De hát mondom, nem voltam én senkinél úgy, a barátoknál voltam." ${ }^{, 77}$ (older than 51 employee living in Hungary)

The general opinion is that the term of "Csángó elite" just starts to win validity, and the first members are those who at the beginning of the 90's were studying in Csíkszereda. The term has to be strongly linked to ethnic self-identification. Elites with Csángó origin and Romanian identity is not atypical, several members of the Csángó society managed to have success and be recognized, yet as several interviewees underlined being Csángó and being with Romanian identity are mutually exclusive.

\footnotetext{
${ }^{76}$ I was fighting a lifelong, for the Hungarian language and Hungarians. When I cam here in 90 , not in 2001I received the Dénes Csergei silver grade of the Hungarian Culture Foundation, literary award, then 3 years ago the Sándor Petöfi freedom of press prize, not about 2 weeks ago, the Hungarian Intellectual Protect the Future gave the Steadily diploma, for my work in the sake of the Hungarian nation. Well, I haven't served particularly for any of them, but what I did, what I wrote during my life I did because it was instinctive to somehow keep a track about Csángós, because we continue to disappear, to assimilate. The development of the intellectuals is in vain, because they can't survive there, because the people do not want the the Hungarian. Why? Because there is the natural and the legitimate way of thinking. In vain, good, that a Csángó speaks Hungarian, good, is an excellent thing to preserve the mother tongue, but if one only knows the Hungarian language, one can't succedd anywhere. If goes to the city, left the village, left the reservation to the big world, there he/she is lost. There Csángós have life legitimacy and strength, if speaks both language perfectly.

${ }^{77}$ I wrote to Korunk, the Igaz Szó, I came to Hungary on several time, and people from other countries came to me, and finally I ended up in the interest of the Security. Once I was called in and I was to told that I am in too good relations with foreigners. That is not allowed, is high treason. If I came to Budapest, as soon as I went home, I had to pack out, Had to say whom I have visited, had to make a report. I said that, but I wasn't visiting anyone like that, I was only at friends.
} 
"Szerintem mindig is volt értelmiségi rétege a moldvai magyarságnak, legfeljebb más tartalma volt, más embereket neveztek, vagy más státuszt soroltak az értelmiségi szférába. Igen, a kántorok, akik lehet, hogy írástudatlanok voltak, de vezetöi voltak egy adott társadalmi rétegnek, és ezek a társadalmak bizony müködtek és teljes értékü világot éltek, mint bármelyik magyarországi paraszti társadalom. De ezen felül nem csak magyar irányba, hanem román irányba is. Sok csángó beépült, egyetemet végzett és vezetök lettek. Nem csak úgy nevezett értelmiségiként, hanem elitként is müködtek, hát nagyon sok mai moldvai gazdag, vagy tudós, vagy bárminek csángó gyökerei vannak. Ezek a gyökerek, nyilván nagyon mélyre visszamennek, mert nem a 89 utáni eseményeknek köszönhetö ... akkor ott van a papképzés, amiröl lehet tudni azt, hogy amikor a jászvásári szeminárium megalakult akkor magyar falvakból vittek oda kispapokat. Minden esetre az biztos, hogy egy úgynevezett papi elit réteg ennek a rendszernek köszönhetöen kialakult. Ök iskolát végzett, értelmiségi emberek. "78 (36-50 years old employee living in Hungary)

If the elite exists, how can it be characterized, who forms it? The most general opinion during interviews was that the ultimate elite and the intellectual with the highest prestige were and still are the priests. Seemingly they are losing space, as it concerns opinion leadership, the young generation is not necessarily accepting everything said by the priest, without any remarks or having a personal opinion. Even today, openly opposing the priest is not a wise thing.

\begin{abstract}
„Az igazi iránymutató továbbra is a pap, illetve a múlt rendszerben is gazdagnak számitó emberek, akik akár politikai szinten is jelen vannak, a képviselök vagy hasonlók. Tehát helyi szinten képviselök, a megyébe sem, hanem ott a helyszinen. Ezek lennének az ilyen véleményformálok, illetve mi, ahogy jelen vagyunk és kapcsolataink vannak szülökkel, gyerekekkel. Ami tapasztalható és ajánlatos az, hogy a papnak a véleményével ellentmondani sohasem nyerö. Vannak itt is családok, fiatalok, idösebbek, akik ugyan összevesznek a pappal, de ez nem jellemzö, tehát érdemes inkább megtalálni az arany középutat. Ha a pap ekkor szervez programot, akkor ne szervezzük rá ... Inkább mi alkalmazkodunk hozzá, mint ö hozzánk s ezzel is sikerült sok helyen jó vagy viszonylagos jó viszonyban lenni velük. ",79 (younger than 35 current leader living in Moldova)
\end{abstract}

\footnotetext{
${ }^{78}$ I think Hungarians from Moldova always had an intellectual strata, at most it had a different content, named different people, or other status was enrolled in the intellectual sphere. Yes, the cantors, who maybe have been illiterate, but they were the leaders of a social strata and these societies certainly functioned and lived a full life, line any other peasent society from Hungary. Moreover, not only in Hungarian direction, but Romanian as well. Many Csángós infiltrated, graduated universities and became leaders. Not only they functioned as so called intellectuals, but as elites as well, many rich and scientist or other moldvaians have Csángó origins. These roots, obviously go back very deep, they are not due to the events of 89 ... there is the training of clergy, about which can be known, that when the seminar from Iaşi was formed, then potential priests were brought there from hungarian villages. For any case is certain, that the so called clerical elite strata was developed due to this system. They are educated intellectual people.

${ }_{79}$ The real role model remains the priest, and people who were considered rich in the previous regime as well, who are present even on political level, representatives or similar. Thus, local representatives, not
} 
While on a personal level there were success stories through which some became mayors, political party secretaries, teachers, professors, doctors, cantors, etc, there is no education that aimed in the past to develop an intellectual stratum of Csángós. More precisely there is one, the theology education in Iaşi, where many Catholic priests were educated. Priests constitute the steadiest elite group of Csángós, it is also the group with the most members. They are the most apparent group of intellectuals and often they are the only group seen and acknowledged by the locality. While graduating from any other university is not celebrated by the village, being consecrated as a priest is a feast, usually organized in the home village to which the whole community participates.

“A csángók közül valaki a teológiát kijárta s már pap, pappá szentelték azt má, azt mondják, hogy csángó elit. Arra nagyon büszkék, hogy a faluban, már van két pap, két papunk. Tudják, mert ott szentelik fel a faluban, vagy valahol a környéken és a helyi pap, a plébános elmondja. " 80 (36-50 years old employee living in Moldova)

One interviewee thought that priests - having the greatest impact in the community - are the ones who decide everything even at political elections. In a rural, traditional community the highest intellectual is the priest and the opinion of all others comes next. The literature focusing on Csángós always paid special attention to priests and their role in the community along the changes of history. Representatives of the Hungarian origin of Csángós often call priests from Moldova as “janissaries”.

„Most én ezt nem így közeliteném, én úgy gondolom, hogy ők akarnak lenni a csángó elit. Csak ám nem azok, amik akarnak lenni. Nem képesek lenni a csángó elit, mert elmesszedtek a csángóságtól, tehát a csángó lélektöl. Az a baj, hogy lehúzzák még az olyanokat es mint én, erőszakkal mondja, hogy „,várjak, mert lesz nekem magyar mise” majd a gyerekeim beolvadnak. Ök eröltetik magukat csángó elitnek, de ök nem csángó elit. Ök a csángóból kiszakadott janicsárok, ameljikek a csángó elit ellen dolgoznak. "81 (older than 51 current leader living in Moldova)

even on county but on local level. These could be the so called opinion leaders, and us as we are present and have relations with parents and children. What can be seen and is recommended that contradicting the opinion of the priest is never a good idea. There are families here as well, young ones, older ones, who do take up the priest but this is not typical, so it is better to find the golden mean. If the priest organizes a program on a time, then we shouldn't over schedule anything. ... Rather we adapt to him, than the therway around, and by this we managed to be in good or in relatively good relation with them in several locations.

${ }^{80}$ If someone from Csángós finished theology and became a priest, ordained as priests he is seen as a Csángó elite. People are very proud, that from the village there is already one priest, two priests. People know that, because they are ordained in the village, or somewhere in the region, and the local priest announces it.

${ }^{81}$ Now, I would not approach this topic like that, I think they want to be the Csángó elite. Only that they are not that what they want to be. Can’t be the Csángó elite, they furthered away from Csángós, from the Csángó spirit. The problem is that they are pulling down, even people like me, telling me with force, that 
Regardless if the priests are seen or not as elites, more accurately as Csángó elites, or they are seen as members of the Romanian community, their local power is very high. Jannisary priests are not applying anymore to the God fearing and the fear from hell of the Csángós, they rather appeal to their reason.

„Az aki hazajön a faluba és azt mondja, hogy a magyar nyelv az valami ördögi ... az valami 20 éves szöveg. Most nem azt mondják, hanem azt, hogy mit nyomod ezt a nyelvet mert úgyse tudod rendesen. Inkább beszélj románul mert Romániában vagy. Az ilyen ember az én szempontomból nem értelmiség. ",82 (36-50 years old employee living in Moldova)

Contrary to the education of priests that was organized in Moldova, the highly educated group of Csángós - with Hungarian identity - started to develop as a consequence of the Hungarian education in Transylvania.

“Talán még azt el tudom fogadni, hogy kialakulóban van egy szük csángó értelmiségi réteg, és ez az a réteg, aki a 90-es években Csíkszeredában tanult. Borbáth Erzsébet nagyon komolyan csinálta ezt a csángó oktatást és célja volt vele, hogy a csángó gyerek öntudatára ébredjen, maga döntse el, hogy magyar-e vagy román, és nem küldte haza azt sem aki román érzelmi volt. Megnyitotta a lehetöséget a továbbtanulásra. Azokból, akik akkor egyetemre kerültek és lediplomáztak, abból alakult ki az a szük, az a nagyon szük réteg, aki irogat, aki tényleg kutatgat. ${ }^{, 83}$ (younger than 35 employee living in Hungary)

One problem of the Csángó elite is linked to this problem, namely that several members of it are living in Hungary and are Csángó elites in (or from) Hungary, strongly connected with the home village, but not present in the everyday life of the community.

“Az az alapvetô probléma megitélésem szerint, hogy a csángó értelmiség kialakulása függetlenül történt meg a csángó lakóközösségek, vagy falvak állapotától, magyarul nincs meg a lehetöségük vagy nagyon korlátolt a lehetöségük arra, hogy a helyszinen értelmiségi létformát élhessenek, amiböl következik, hogy a többség nem megy vissza. Nem lehet

\footnotetext{
"I should wait, there will be Hungarian mass", and then my children will be assimilated. They are forcing themselves as Csángó elites, but they are not Csángó elites. They are janissaries torn out from Csángós, who are working against the Csángó elite.

${ }^{82}$ Someone who returns to the village and says that the Hungarian language is something diabolic ... is a 20 years old speak. Nowadays they are not saying that, but that why are you forcing this language, since you don't know it properly anyway. You should rather speak in Romanian because you are in Romania. These kind of people are not intellectuals in my eyes.

${ }^{83}$ Perhaps I can even accept, that a very narrow strata of Csángó intellectuals is in development, and this strata is the one that was studying in the 90's, let's say during 90-99, in Cskíszereda. Erzsébet Borbáth did this Csángó education very seriously, and she had a goal with it, to awake self-consciousness in Csángó children and decide for him/herself whether is Romanian or Hungarian, and she did not sent home those ones who had Romanian feeling. Gave the opportunity to continue studying. From those, who then were studying in universities and received a degree, evolved the narrow, the very narrow circle of those publish, who actually conduct research.
} 
elvárni egy Iancu Laurától mondjuk, hogy egy csángó faluban akár Magyarfaluban tanitóként éljen, mert maximum ez lehetne, amikor öneki ennél sokkal összetettebb és nagyobb tehetsége van. Úgyhogy ez egy nagyon nehéz probléma. A másik, amit azért látni kell, hogy bizonyos felsőfokú végzettségre nagyon nagy szükség lenne ott, az állatorvosra, az orvosra, fogorvosra, stb. és azok is meghatározó vezetöi lehetnek az adott közösségnek vagy falunak. Ez a fö probléma jelen pillanatban, hogy az értelmiség az ottani értelmiség az képtelen ott megkapaszkodni. $"{ }^{84}$ (older than 51 current leader living in Hungary)

The education of these young Csángós in Hungary raises another question: whether if they are - and as such the Hungarian support - serving the community as well, or are only individual successes, that can't be implemented in Moldova. Based on fieldwork it seems that while more and more young Csángós are graduating from different Hungarian or Romanian universities, the community recognizes these as values, as achievements, but also considers these as personal issues, as something that is good for the graduate only. Being a doctor or a teacher is seen as something worthy for the doctor and for the teacher only, and not for the community. Personal successes, even if providing services is not a community success, as it is seen by the interviewed elites. In order to consider someone elite is very important to serve and to represent the best interests of the community above personal goals; otherwise we can only speak about one's personal successes rather than him/her being elite. The same or at least similar idea was formulated by saying that funding the education and as such the nurturing of the Csángó Hungarian intelligentsia; the communities will be also supported. Yet several representatives of this first generation said, that they felt that the community doesn't see how beside the personal support the community is aided.

Interestingly for many interviewees, being intellectual is not necessarily equal with, or does not necessarily require to be highly educated as well. Even if one has only 4 classes but has a clear overview about things and can be trusted and he/she will do the job, one can be seen as intellectual. One of the most detailed definitions of who can be considered intellectual among Csángós is given by someone with several degrees, who

\footnotetext{
${ }^{84}$ What I consider the basic problem, is that the development of the csángó intellectual happened independently from the csángó communities, or the state of the villages, namely they don't have the possibility, or their possibility is very limited in conducting an intellectual lifestyle there, locally, which results that the majority is not returning. You can't expect from a Iancu Laura for example to live as a teacher in a csángó village, even in Magyarfalu, because that's the top she could do there, when her talent is much more complex and greater than do to so. So this is a very difficult problem. The other thing we have to see, is that certain higher educated people are very needed there, a veterinarian, a doctor, a dentist, etc. and they could be decisive leaders of a community or village. This is the major problem currently, that intellectuals, intellectuals from tare uncapable to hold on there.
} 
returned to Moldova even if he did not have the certainty of a well paid, assured job. Currently works at the MCSMSZ:

\begin{abstract}
"Értelmiséginek számitanak és számitottak a papok és ugyanúgy a tanitók. ... Továbbá számomra értelmiséginek számit az, aki megtalálja a helyét és becsülettel eltudja végezni azt, amit elvállalt. ... Az, hogy hazajön, ha itt a csángó szövetségnél, ha máshol el tud helyezkedni, talál megbecsülést, ugyanúgy karriert tud épiteni, ha egyszerü munkásként is, akármilyen szakmában is. Szerintem értelmiségi az, aki jól átlátja a környezetét, a világot és a megfelelö következtetéseket tudja leszürni és meg tudja emészteni az egész információ halmazt, ami egy nap, egy órában, egy idöszakban ér. Véleményem szerint ez az értelmiség. Aki hamarkodottan dönt vagy folyamatosan tévesen itél meg dolgokat az szerintem nem értelmiségi. ... Véleményem szerint az számit értelmiségnek, akkor lesz presztizse egy értelmiséginek, nem akkor ha doktori címet szerez vagy mit tudom én hány kötetet ad ki külföldön, mert itt a faluba lehet, hogy nem is tudják, hanem mikor hazajössz és fel is tudsz mutatni valamit, hogy itthon teszel valamit a közösségért, akkor kapod meg a presztízst. ... Ki itthon van és itthon építi fel a karriert. ... Túl sok a karrier, de mondjuk aki itthon találja meg a helyét és itthon érvényesül, annak nagyobb a presztízse. Külföldön évente adhatsz ki százával könyvet és szerezhetsz doktori elismervényt és akármit, ha itthon ebböl semmit se tudsz kamatoztatni, ha nem tudsz adni a falunak, hogy az érezze igen érdemes rád hallgatni és téged követni. ${ }^{, 85}$ (younger than 35 current leader living in Moldova)
\end{abstract}

He considers that we are living in a society which lives at a higher speed and everyone with a degree wishes to get rich, have a car, buy a house immediately rather than to take step by step the road that leads to all these. Another problem is that many of the young graduates do not dare to take the risk that goes hand in hand, with searching for a job in Moldova with a Hungarian degree. From the graduated Csángós only a few are returning and seeking to build up a "career" in Moldova, based on the knowledge accumulated at a Hungarian or Romanian university. Mostly because high education is still rare among Csángós, few are accepting to gain prestige in the eyes of colleagues and chiefs step by step; they are rather asking a fast recognition for their degree.

\footnotetext{
${ }^{85}$ Intellectuals are and were the priests and also the teachers. ... Furthermore for me intellectuals are those, who can find his/her place and can fulfill with honor all he/she undertakes. ... That if comes home either at the MCSMSZ, or can find his/her place in any other job, find esteem, can build a carrier as a simple worker in any profession. I think intellectual is, who well understands his/her environment, the world and can draw the proper consequences and can digest the entire information set, which affects $\mathrm{him} /$ her on a specific day, hour or period. I think that is the intellectual. Those who decide inconsiderate or continuously mistrial are not intellectuals. ... In my opinion those are intellectuals, an intellectual will have prestige, not when gains PhD degree or I don't know how many volumes he/she publishes abroad, because maybe here, in the village no one knows, but when you come home and you can show up something, that you do something at home for the community, then you gain prestige. ... Who is at home, and builds up a career att home. ... Career is too much, but for example those who find his/her place and prevails at home, has a higher prestige. Abroad you can publish hundreds of books and you can earn phd degrees, if at home you can't exploit any of these, if you can't give to the village, so they can fell than is worthy to listen to you and follow you.
} 
Wishing to accumulate everything as fast as possible, turns children to opt to work in a foreign country, rather than to continue their education. The desire to make money is very much present in the young generation and not only forms their opinion regarding education, but later on, when enrolled in transnational migration forms their attitude toward those who chosen to stay and learn.

„Ha befejezik is a középiskolát nem fognak egyetemre menni, hanem ezt a pénzszerzési vágyat próbálják kielégíteni, és ha nem is sikerül mikor haza jönnek, akkor is ilyen fönt hordott orral járnak, hogy kicsodák ök, mert ök Olaszországba vagy mit tudom én hol dolgoznak pedig lehet, hogy csak egy öregnek az ágynemüjét cserélik ... Lehet többet keresnek azzal mint én. " 86 (younger than 35 current leader living in Moldova)

In order to speak about the elite of a community, following the most common acts of distinction there are cultural, economic and political elites. The cultural elite is the group most comprehensively discussed by interviewees, the major part is composed by the so called intelligentsia.

Speaking about the economic elite, two groups of people should be characterized, one those who were wealthy before the regime change as well, and those who enrolled in transnational migration at the beginning of the 90's. The local economic elite is considered of Romanian origin, and themselves are not interested and quite inactive in the Csángó matter. There is a negative opinion toward those who managed to step out materially from the mass. One interviewee suggested that these people should not be considered as Csángó elite on two matters, because they are assimilated and consider themselves Romanians and they are not present economically on a national level.

“A csángóknak nincsen gazdasági elitjük, nincsen magyar öntudatú tőkés, aki ott valamit kezd a társadalommal, tehát itt egy nagyon nagy szegénységben sínylödő népcsoportról van szó. Hát van egy-két gyerek, aki Izraelben keresett néhány dollárt, hazajött és valami befektetést kezdeményezett a saját falujában, de az is ilyen spekuláció révén, jutott el oda, hogy esetleg megszerzett magának néhány hektár földet, tehát az sem mondható gazdasági elitnek. Nincs tökéje, a csángónak nincs tőkés rétege. ... Az a kérdés, hogy azok akiknek van busztársaságuk Moldvában, vagy van valamilyen vállalkozásuk, azok magyar öntudatúak? Hányan vannak, akik magyar öntudatúak, na ez a kérdés, hogy az csángó magyar öntudatú vagy már román? Lehet, hogy a származása az csángó, de aki nem tartja magát

\footnotetext{
${ }^{86}$ If they graduate middle school, they won't go to universities, but will try to satisfy the desire of raising money and even if they fail to do so, when they come home they walk so proudly like they are someone, because they work in Italy or I don't know where, although maybe that they are only changing the sheets of an old man ... but is possible that they earn more than I do.
} 
magyarnak, vagy aki már nem magyarnak tartja magát, nekem mért lenne jogom azt mondani, hogy ö magyar? ",87 (younger than 35 current leader living in Hungary)

When speaking about the economic elite it is very important to mention the negative opinion of the community towards those who are wealthier than the rest.

"Vállalkozók, igen. Öket nem úgy tartanám, mert ismerem a helyzetet, és ilyen vállalkozó biztos, hogy nem tiszta módszerrel vette azt a dolgot, vagy kezelte. Emelem a kalapom, de azt azért nem mondanám, hogy elit." ${ }^{\prime 88}$ (36-50 years old church representative living in Hungary)

Just as in the case of educated people, in Csángó communities as soon as one is wealthy, especially if they accumulated wealth over the borders of the village, they don't consider themselves Csángós and the success is a personal issue with no consequences to the village. Personal success once again is not enough to name someone as elite. In order to be considered elite one has to serve the interests of the community as well, with the accumulated - human and/or material - capital.

Being present in the political sphere and being considered as elite, as Csángó elite, is probably the most difficult sphere to conquer. Being elected as a mayor is possible almost exclusevly as members of a Romanian party. Campaigning in the colors of the Hungarian party, usually results in being elected - in the best scenario - as councillor. In a couple villages elected mayors are Csángós themselves, some of them are in good relations with the MCSMSZ - according to one of the leaders of the organization - yet they have to be affiliated politically as well. The third option, is probably the most difficult, is running as an independent, but no actual examples are known.

“A román politikai pártok a csángókban a magyar érzelmet próbálják lenyomni, hogy ne legyen, de ha létezik is, maradjon a szük családi körben. Konkrétan ez valahogy így néz ki, hogy egy csángóközösség polgármestere, ha csángó is, a falu szülöttje, nem az a fontos, hogy csángó, hogy csángó magyar, hanem az, hogy ez a dimenzió ne legyen fontos benne.

\footnotetext{
${ }^{87}$ Csángós don’t have an economic elite, don’t have capitalists with Hungarian consciousness, who deals something there with the society, so there is a ethnic group that languishes in very great poverty. There are one or two kids, who collected some dollars in Israel and came home and initiated some investments in their village, but they ended up through speculation to acquire some hectare of lands, so they can't be called economic elites either. Has no capital, Csángós have no capitalist strata. ... And that is the question, whether those who have bus companies in Moldova, or some sort of companies those or of Hungarian consciousness? How many of them are of Hungarian consciousness, that is the question, whether they re of csángó-hungarian consciousness or Romanian? It is possible that their origin is Csángó, but who doesn't consider him/her-self Hungarian, or does not consider anymore him/herself Hungarian, why should I have the right to say that he /she is Hungarian?

${ }^{88}$ Entrepreneurs, yes. I wouldn't see them as such, because I know the situation, and these entrepreneurs certainly did not buy or treated that thing with clear methods. I raise my hat to them, but I would not say that they are elites.
} 
Az RMDSZ oldalán ez a dolog jelenti a legnagyobb követelményt, hogy úgy mondjam, de ennek még nincs nagy támogatottsága bár nyitottság az van. ${ }^{, 89}$ (younger than 35 former leader living in Moldova)

Others think that people who could form the Csángó elite do exist but their local position and role is still uncertain and problematic.

„Kulturális csángó elit: abszolút igen, teljesen igen, egyszer ugye akik pedagógusok lettek az elsö generációból. Többen Székelyudvarhelyen végezték el a Benedek Elek tanitóképzöt, vagyis képzett fiatalok voltak és gondoltuk most már lehetne tanitani magyarul Moldvában. Nem volt elókészitve semmi. Tehát nekem a nagy-nagy fájdalmam az volt, hogy amig mi becsülettel, sok-sok erővel végezzük a munkánkat, bent nem mozdult senki. Szakiskolát végzett gyerekek, jól felkészült kömüvesek, autószerelök, stb. visszatérve az annakidején megfogalmazott legelsö kérdésre, hazamentek Moldvába munkanélküliek lettek, feketemunkára kimentek Magyarországtól Izraelig, Izraeltől Olaszországig, Portugáliáig vagy mit tudom én milyen irányt választottak. Szóval nem volt semmi megtervezve, elökészitve ott s akkor ezek az Udvarhelyen végzett gyerekek Székelyföldön helyezkedtek el. ... utólag mikor rájöttem, hogy nem volt elökészitve semmi és nem is mehettek haza ... történt bennem egy nagy, mit mondjak, egy nagy csalódás, nem is csalódásnak mondanám, kiábrándulás azokból a szimbolikus felvállalókból, akik velem elhitették azt, hogy mi azokat a moldvai csángó értelmiségi fiatalokat fogjuk kinevelni, akik a tudást visszaviszik a közösségüknek és ott fognak bent dolgozni azért, hogy ott bent is valami megtörténjen." (older than 51 current leader living in Transylvania)

One of the most important questions, when it comes to elite studies is the role fulfilled by the elites and their duty toward the community. This applies even harder when the elite is under development, under formation. Opinions are parted, from undertaking of Csángó-Hungarian identity, to being successful and drawing attention to

\footnotetext{
${ }^{89}$ Romanian political parties are trying to push down the Hungarian feelings in csángós, so that doesn $1 \mathrm{t}$ exist, but if does exist, to remain in the narrow family circle. Specifically this I how things look like, if the mayor of a Csángó community even if is Csángó, is the native of the village, what is matters is not that he/she is Csángó, Csángó Hungarian, but that this dimension should not be important at all. On the front of RMDSZ this is the highest requirement, to say so, but this has no high support, yet, but people are opened to it.

${ }^{90}$ Cultural Csángó elite: absolutely yes, totally yes, first those from the first generation who became teachers. Several graduated the pedagogic school in Odorheiu Secuiesc, they were educated young people, and we thought that now it would be possible to teach in Hungarian in Moldova. There was nothing prepared. My great-great pain was, that while we honestly, with a lot of effort, we made out works, inside (in Moldova) no one was moving. Children with professional education, well prepared masons, mechanics, etc. returning to the originally formulated question, returned to Moldova and they became unemployed, and went to illegal work from Hungary to Israel, from Israel to Italy, Portugal or I don't know what other directions they used. So nothing was planned, prepared and these children who graduated in Odorheiu Secuiesc settled in Szeklerland. ...later when I realized that nothing was prepared and they could not return home ... how should I say it, a big disappointment happened in me, not even disappointment, but a disillusionment from symbolically embracers, who made me believe thatwe are going to educate the young csángó intellectuals who will bring back knowledge to their communities and will work there so a change can occur there too.
} 
Csángós, or to be present in the community and above personal goals serve the community, several other expectations - more or less defined - are named.

One of the most basic expectations was not to lose spiritual consciousness, to know about him/herself that is Csángó and to admit and undertake his/her Csángó (Hungarian) identity. A more conscious role is to form and shape, the future of Csángós, to maintain the culture and identity, a role encountered in the case of several minority intellectuals and intellectuals of the previous centuries.

As one interviewee said, being part of an elite that lives its life in a surviving form should not be sufficient. Elites should be role-models and while highly educated Csángós are to some extent seen as such, their position in the village is still uncertain.

"Arról van szó, hogy vannak lehetöségek, amivel élni érdemes. És hát mi ebben teljesen mintaként szerepelünk, annak ellenére, vagy azzal együtt, hogy nem Mercedesszel megyek haza és nem a legszebb ruhákban, igaz nem a legszebb ruháimat vittem haza, mert féltettem a szép pesti ruháimat a portól, azokért sok pénzt ad az ember és pár van és vigyázok rájuk és akkor mindig azzal mentem haza, ami jó otthon. Nem akartam kiválni a közösségböl, a helyi társadalomból, nem volt aranygyürü az újamon és aranylánc a nyakamon. Nem egyértelmü ez a példaadás, de azért ott vagyunk, mint ilyen kétes valakik. Sokan kérdeznek, hogy mit kell csinálni, hova kell menni, hogyan kell bizonyos fokozatokat, átélni, vagy átvészelni. ".91 (36-50 years old employee living in Hungary)

While members of the younger generation could fulfill the role of models, many of them are living in Hungary, and several of those who are in Moldova are not valued locally but rather by scientists and/or by activists from Transylvania and Hungary.

"valósággal ellene dolgoznak bent a mai moldvai csángó fiatal értelmiség, hogy is mondjam, tehetségének elismerése és munkájának példaértéküvé tétele ellen dolgoznak. Ellene dolgoznak, sehol nem hallom egyetlen egy interjúban, sehol-sehol hogy ezeket az embereket bentröl, Magyarországon igen, bentröl úgy a gyerekek elé, a közösség elé példává állitanák. Sehol nem hallottam még ezt, nem teszik példaértéküvé, nem népszerüsítik a munkájukat." ${ }^{\text {"92 }}$ (older than 51 current leader living in Transylvania)

\footnotetext{
${ }^{91}$ Thing is that there are opportunities worthy to live with. And well, we are totally examples in this, despite that, or along that I am not going with a Mercedes and in the nicest clothes, truth is that I did not brought home my nicest clothes because I feared my beautiful clothes from Budapest from the dust, for those people spend a lot of monies and I only have couple and I take care of them, and I always took home what was just good for home. I never wanted to b different from the community, to step out from the local society, never had gold ring on my finger and gold necklace. This role-modeling is not clear, but we are there, like some sort of dubious persons. Many ask us, what to do, where to go, how some degrees should be lived or survived.

${ }^{92}$ In Moldova they are truly working against the, how should I say it, recognition of talent and making the work of the young moldvaian csángó intellectuals exemplary. They are working against it. I never heard not in one interview, never-never that these people are from inside, from Hungary yes, but from inside
} 
As a following logical step would be that by having role models they could represent and serve the Csángó matter. There is a very skeptical question whether some graduated and dedicated young Csángós can solve what is happening in Moldova. Can they suppress assimilation? Are they able to make up for what was neglected for centuries? Some are more skeptical with the elite as such, while they think that there is a change in the social structure of Csángó villages and the community it is stillprecocious to speak about the Csángó elite.

“A csángó elit ... ez egy nagy kérdés ... többen fejtegették, hogy ki a csángó elit, ki nem ... hát csángók vannak akik, ... van csángó elit. A többség az sajnos román anyanyelvü és román identitású ... és otthon ... Az elrománosodott, román egyetemen, vagy bárhol végzett, román öntudatú csángó katolikusok, azok nem nevezhetöek nyilván csángó elitnek. Ök már teljesen asszimiláltak, román etnikumhoz tartozó csoport. A csángó elit...hát lediplomáztunk jópáran, de én úgy gondolom, hogy amig nem születik meg egy olyan csoport, aki önállóan ir, gondolkodik, kutat, felmutat valami szellemi hozadékot, addig nem igen tudunk csángó elitröl beszélni, mert önmagában az, hogy lediplomázunk százan, ebböl sajnos nem lesz csángó elit. ${ }^{, 93}$ (younger than 35 employee living in Hungary)

The lack of the intelligentsia might be originating from not having role models, historical personalities who represent worthwhile models to follow. Some of the interviewees mentioned that the Csángó elite forms a thin strata, but the number is growing. Yet these elites do not constitute examples for the community either because they are not living in Moldova, and as such they are known only by the home-village, or their position is weakened by local and ethnic conflicts.

“Az egész csángó ügy azért csúszott el, mert nincs egy példaképünk, ahogy a magyaroknak volt egy Széchenyi, vagy Erdélyben Tamási Áron, meg Áprily Lajos, nekünk nem volt ilyen. Nem volt egy példaképünk, nekünk Domokos Pál Péter bácsi lett volna, de nagyon idös volt mire jött a váltás. Azelött le volt fojtva ez a dolog, nem is lehetett erröl beszélni. Az egész csángófilozófia meg van csúszva egy az egybe. Az egész másképp alakult volna, ha van egy-

(Moldova) to be presented to children, to the community as role models. I never heard this, their work is not made as exemplary, is not promoted.

${ }^{93}$ The Csángó elite ... this is a big question ... several people reasoned who is the Csángó elite, who isn’t ... there are Csángós, who ... there is a Csángó elite. The majority is of Romanian mother tongue and Romanian identity ... and at home ... Csángó Catholics with Romanian consciousness who were assimilated, graduated in Romanian universities or anywhere else can’t be called Csángó elites. They were entirely assimilated, they are a group that belongs to the Romanian ethnicity. The Csángó elite ... well several of us got a degree, but I think that until a group of people who can independently write, think, research, show an intellectual outcomes born, until then we can’t really speak about Csángó elite, because simply by one hundred of graduates, unfortunately doesn’t form the Csángó elite. 
két ember, akihez el lehet menni tanácsot kérni, aki lecsitít ha éppen az kell. Egy vezéregyéniség." ${ }^{\text {"94 }}$ (older than 51 former leader living in Hungary)

The validity of the elite, being known and recognized by the community is wronged by not having legitimate events where these persons could be presented. By legitimate usually people understood events accepted and approved by the local authorities, especially the priest. Csángó intellectuals and cultural elites can live the life of an intellectual mostly outside of Moldova, and in Moldova they are known - in the best case scenario - in their villages only.

"Én személyesen ismerem Nyisztor Ilonát is, Petrás Máriát is, ezek ugye az énekesek, Iancu Laurát, aki költöó, tehát ezt a nagyobb kört is ismerem. De öket nem ismeri mindenki. Saját szülöfalujába ezek a személyek mind ismertek, de az egész csángóközösség nem ismeri. ... Nincs meg az a fórum, ahol megismerhesse a közösség. Ezért olyan problematikus, hogy ott vannak Budapesten, a csángó elit ott van, köszönjük szépen, de itt öket nem ismerik. ",95 (younger than 35 former leader living in Moldova)

Like in many rural communities the knowledge of traditions - referring customs, healing, etc. - among Csángós as well has a high value, although some might say that it is fading nowadays.

"A csángó elithez sorolnám azokat az idös asszonyokat, akik rengeteg népdalt öriztek meg. A magyar nemzet elitjének is mondhatnám öket, mert olyan értékes dolgokat hagyományoztak ránk, amit én nem tudok, holott egyetemet végeztem. ${ }^{, 96}$ (younger than 35 church representative living in Hungary)

„,vannak még oljanok fiatalok közül es meljikek leghamarabb hezzám vagy anyámhoz mennek, hogy megkérdezzék, hogy miljen gyógynövényt, mit lehetne, hogy fözzön a gyermekének s aztán viszi el a doktorhoz." ${ }^{, 97}$ (older than 51 employee living in Moldova)

\footnotetext{
${ }^{94}$ The entire Csángó matter, slipped away, because we don’t have a role-model, like Hungarians had a Széchenyi, or in Transylvania there was Áron Tamási and Lajos Áprily, we had no such person. We had no role-models, Pál Péter Domokos would have been such a person for us, but he was very old by the time change (regime change) has come. Prior to that the entire topic was throttled, could not even talk about it. The entire Csángó philosophy is skewed as it is. Thing would have been differently, if there is one or two people, to who one can go for advice and who can calm down if that's the right thing. A leader.

${ }_{95}$ I personally know Ilona Nyisztor, Mária Petrás, these are the singers, Laura Iancu who is a poet, so I know this larger circle. But not everyone does. In their villages these people are all known, but they are not known by the entire csángó community. ... There is no such forum where the community could meet them. This is why is so problematic, that they are in Budapest, The Csángó elite is there, thank you very much, but they are not known in Moldova.

${ }^{96}$ I would name as Csángó elites those old women, who preserved many folk songs. I could name them as elites of the Hungarian nation, because they demised so valuable things, that I don1t know even though I have university graduation.

${ }_{97}$ There are from the young ones too, who first come to me or my mother, to ask which herb to boil for the child and goes to the doctor afterwards.
} 
Although in the case of the Csángó elite speaking about a second generation elite is an overstatement, speaking about generations - elders and children - of the elite members could bring interesting insights. As one interviewee noted the families of young intellectuals usually were well situated members of the society who put an effort to educate their sons. The social position of the family, the economic well-being of the parents is determinative in the case of highly educated young Csángós as well. If one is educated one should be able to prove in material aspects as well.

“Akik Magyarországon tanultak, ugye befejezhették az iskolákat, sajnos még nem értek el olyan szintet, hogy elitként legyenek elszámolva. Szerintem, sajnos a csángóknál, de talán máshol is, a családi háttere, a gazdasági háttere, mondja meg, hogy elit vagy nem elit. [...] Az, hogy mit szedett össze, hogy mije van. Ha már van iskolája, ha már van érettségije, akkor legyen valamije is. Tehát legyen egy autója, stb., s akkor azt mondják, hát persze, hát ö sokat tanult. ",98 (36-50 years old employee living in Moldova)

Turning to the question of what happens to the children of the elite raises new opportunities for interpretation to the generational aspects. The question is even more important in the case of those who are settled in Hungary. The so called first generation can fulfill its role from Hungary, yet their children - presumably - won't be active members of the Csángó society. While the first generation is not lost from the cause, having an active role in the community is even harder for the proceeding ones.

Some argue that the Csángó community always had its elites, and the size of the elite group might haven been as large as today. Arguing that we are not actually dealing with a first generation elite, what makes this investigation relevant is that after the regime change a greater social interest was turned toward Csángós, and conscious acting and duty toward community became more important.

“Mondjuk a második világháború után, a szocializmus elött vagy akár a szocializmus alatt is, föleg a városon élö csángók körében, lehet, hogy létszámba voltak annyian, mint ahányan mi most vagyunk, csak nem volt az a nagyfokú társadalmi érdeklödés, mint manapság. "99 (36-50 years old employee living in Hungary)

\footnotetext{
98 Those who were studying in Hungary, graduated in different schools, unfortunately did not achieved such levels yet, that they could be counted as elites. I think, that unfortunately at Csángsó, but maybe at other places as well, family background, economic background tells whether one is elite or not. [...] What one accumulated what one owns. If one is educated, has a baccalaureate, should have something. That is, should have a car, etc, and then people say, that of course, he learned a lot.

${ }^{99}$ Lets say after the second Worl War, or prior to socialism or even durign socialism, especially among Csángós living in towns, maybe, that in number there were as many as we are, only that it wasn't that intense social interest like nowadays.
} 
While the role of elite members in Moldova and Hungary is debatable, some think that Csángó communities and their interests should be sustained on three levels and Csángó elites should be present in each of these levels. Firstly in Moldova, then in Hungary and finally on the European level. Not only Csángós, but Hungarian and Romanian politicians as well should be present much more consciously.

“A csángókat három lábon kell tartani. Az egyik az ott Moldvában, ugye nem kell részletezni hogy mit, a másik Magyarországon mert az egy külön kérdés hogy az Erdélyi magyarság miért viszonyult és viszonyul úgy a csángókhoz ahogy. Tehát egy Magyarországi képviselet nagyon fontos, a harmadik meg egy Európai. Egyébként ez mind a három müködött is többé-kevésbé eredményesen, most az Európai picit gyengülöben van, de arra szerintem nagyobb figyelmet érdemes forditani. Ez elsösorban a magyar külpolitika és bizonyosan az Erdélyi magyar külpolitikának is a feladata. "100 (older than 51 current leader living in Hungary)

Today from these three pillars we can say, that with a different force, all three are active. While many agree that Csángó elites should be locally present it seems that at this moment the Hungarian level is more powerful than the local one.

„Jelen pillanatban erőteljesebbnek látom a kirajzott értelmiséget, mint a helybelit, és egy picit kontraszelektiv is a dolog. "

There is a difference among the activity of organizations which acclaim the Romanian or the Hungarian identity as well. While - according to one of the representatives of a Romanian organization - those associations and foundations that are proclaiming the Hungarian identity, teaching and language are supported by the Hungarian states, Romanians are not funded by anyone.

„, Dar ce folos, dacă de exemplu unii intelectuali, într-un sat catolic, poate să fie el expert la ministerul culturii, sau oriunde altundeva, degeaba atâta timp, cât el este marginalizat. Cât el de exemplu nu este implicat in proiectele culturale de acolo. "'02 (36-50 years old current leader living in Moldova)

\footnotetext{
${ }^{100}$ Csángós should sustained on three legs. One there in Moldova, there is no need for details, the other in Hungary because it is a different question why Hungarians from Transylvania acted and acts as they do toward csángós. Ergo a Hungarian representation is very important, the third a European. For that matter, all these three were more or less successfully operating. nowadays the European is a bit fading, but I think more attention should be paid to that aspect. First of all this is the duty of the foreign policy of Hungary and certainly the Hungarian foreign policy of Transylvania

${ }^{101}$ At present moment I see the group of intellectuals who swarmed out more powerful than the locally present one, and the issue is a bit contraselective too.

${ }^{102}$ But of what use, if for example, some intellectuals, in a Catholic village, may he be an expert at the Ministry of Culture, or any other place, is useless as long, as he is marginalized. As long as he is not involved in the local cultural projects.
} 


\subsection{The Catholic Church}

Learning in Hungary is not the only channel through which one could earn prestige, status or wealth, but nowadays seem to be the most accepted. Earning high prestige and status through learning has a very specific case: the church. Becoming a priest is still a way of achieving the highest prestige for several children and having a priest in your family is something to be proud of. Even today many think that the priest has the last word in the village and he can decide the outcome of the political elections as well. His word is something to fear of. Other channels are linked to migration as well, by engaging foreign work or guestwork and by this accumulating wealth that is unthinkable without migration.

The role played by the Catholic Church in the everyday life of Csángós, in the development of the elite and in the Csángó matter as well is very accentual. The role of the Catholic Church and religion is widely discussed in Historical and Ethnographic studies - for example (Kinda, 2005, 2006, 2007) or (Pozsony, 2002) just to name the most recent ones - yet a short presentation as priests are seen by interviewees might bring useful insights. Local priests, leaders of the dioceses of Iaşi, and the leaders of Hungarian Catholic Church, the two delegates of the Iaşi episcopate to Budapest are also influentials, forming and leading public opinion. The introduction of the Hungarian language to the masses is the most debated topic in which priests play an important role.

Two priests were delegated by the Romanian Catholic Episcopate to Budapest with several goals: one is to hold masses in Romanian language in Budapest, the second to get a postgraduate degree and third - and most important as it concerns Csángós - is to make the preparation for introduction of Hungarian masses in Moldova.

In February 2010, a Forum was organized by one of the delegated priests. The aim of the meeting was to get together all those interested and active in the Csángó matter, NGO-s from Moldova and Hungary were invited. One of the basic questions was the problem of Hungarian masses. The opposition among the delegates of the episcopate of Iaşi and the rest - Csángós from Hungary and Moldova as well - was obvious. The official opinion of the episcopate of Iaşi - as it was represented by the delegates - was that it all takes time, Csángós should be thought, because today not too many people ask for the Hungarian masses or even those who are asking for it wouldn't understand it.

„,Gherghel püspök mondotta, hogy „,lesz magyar nyelvü mise, erre készüljünk”. Nem mondta, hogy ma vagy holnap lesz. Én biztos vagyok benne, hogy ha itt vagyok én és a kollégám, annak oka van. A püspök atyának van egy terve velünk. [...] Itt van a bíboros 
atya, a püspök atya, vegyünk példát róluk. Lépésenként menjünk elöre, ne egyszer a román, egyszer a magyar jöjjön elö. Keresztények vagyunk, hiszünk Istenben, nem az a fontos, hogy milyen nyelven beszélünk. Az a lényeg, hogy megértsük egymást." "103 (Mariut Felix: Forum)

There is no surprise in saying that the most central issue of the intersection of the Catholic Church form Moldova and the Csángó matter is the introduction of Hungarian masses. Opposition is mainly based on the opinion that Csángós don’t speak Hungarian and even if they do so they don't know the Hungarian mass-schedule.

Liturghia in limba maghiara nu este bine, pentru că limba maghiară este la nivel de cult. Dacă este să luăm să fie folositor oamenilor, vrem să fie în limba pe care o vorbesc oamenii, să fie pe înțelesul oamenilor, păi atunci haideți să facem o liturghie pe graiul lor, că avem preoți şi la şcoală. ""104 (36-50 years old current leader living in Moldova)

While some see the solution in introducing the Csángó dialect, others think that it takes a time of learning, the schedule, and the literary Hungarian and in the meanwhile the solution would be the bilingual mass. Others don't see any impediment in organizing Hungarian masses; it is a basic human right to have masses in one's mother tongue. This later opinion is sustained by dioceses from Transylvania and Hungary as well. Although for several years they tried to remain distant, and not to interfere with other dioceses, in the close past, communication started to pay off. Hungarian mass was organized in one village, in Lábnyik, which can be considered a good start, yet the problem is - according to one interviewee - that for a couple more years these events needs to be induced from outside:

\begin{abstract}
"A baj az, hogy legalább 3-5 évig kivülröl kell indukálni ahhoz, hogy menjen. Maguktól ez nem megy, mert egyrészt a csángók nem tudnak magyarul imádkozni, maximum az idösebbek tudják a népi imádságokat, mert, hogy latin imádság volt meg utána román. Másrészt a papok nagyon eröteljesen kordában tartják őket, de ha kivülröl segitenek nekik, például ahogy mi megszerveztük Pusztinán vagy Lábnyikon akkor örömmel mennek. "105 (older than 51 current leader living in Hungary)
\end{abstract}

\footnotetext{
${ }^{103}$ Gerghel bishop said that, "there will be masses in Hungarian language, and we should prepare for this." He did not say whether it will be today or tomorrow. I am certain, that there is a reason thatwe, my colleague and me, are here. The bishop has a plan with us [...] Here is the cardinal and the bishop, we should take an example of them. We should go forward step by step, not once the Romanian, than the Hungarian comes forward. We are Christians, we believe in God, is not the language we speak that matters. The importance is to understand eachother.

${ }^{104}$ Liturgie in Hungarian it is not good, because the Hungarian language is at the level of cults. If it is to take what is useful for these people, we want in the language they speak, to be at the understanding of the community, let's have a liturgie on their idiom, since we have priests at schools too.

${ }^{105}$ The problem is that for at least 3 to 5 years it needs to be induced from outside. It is not working from the inside, because on one hand, Csángós can’t pray in Hungarian, maybe only the older ones know the folk prayers, because there were Latin masses than Romanians. On another hand, priests are firmly
} 
Inducement is mostly done from Hungary, since the opposite situation as of Csángós can be found in several places in Transylvania, putting the Transylvanian dioceses in vulnerable positions. In the region of South Transylvania assimilation is very strong and there are several congregations where the idea and request of Romanian masses is more and more frequent. While there are places where this topic is not a question anymore, because the majority is Romanian and the celebrations are in Romanian, there are still unsteady localities which puts the Transylvanian Catholic dioceses in a vulnerable position.

There is a cross point of Hungarian teaching and religious aspects which also generates conflicts. Several teachers involved in the education are Protestants and some people think the easiest solution that could give Hungarian religious celebrations to Csángós would be the change of religion. Some - occasionally leaders of the Catholic Church as well - question whether the Protestant Church wishes to reform the Csángós. Those who are familiar with the beliefs and the religiosity of Csángós know that this idea is impossible.

While the main problem is due to Hungarian masses, it is important to know that there are celebrations in Hungarian in Moldova - as one priest said, probably it was a first step in diplomacy - in Iaşi in order to provide the possibility of attendance for students learning in Iaşi. The only problem is that Iaşi - unlike Bakó - is quite far from Csángó villages, and people won’t travel on Sundays just to attend Hungarian masses, they will rather listen the Romanian liturgy. Organizing the Hungarian masses is Iaşi; confirmed the suppositions that almost no one will attend them. Just like it seems much to a priest to travel nearly $100 \mathrm{~km}$ to hold Worship, the distance seems even greater for Csángós living in hidden, badly communicated villages. Iaşi seems even further for the older generation and mostly they are those who speak the language and who presumably could follow the mass schedule. There are some older Csángós, who can’t speak Romanian, and when they had to confess they asked to do the confession in Hungarian.

\footnotetext{
„Volt 2 vagy 3 öreg néni, aki mondták, hogy nem beszélnek egyáltalán románul, csak magyarul, s úgy gyóntak. Jó mondtam nekem semmi baj, mert magyarul miséztem a Iaşi egyházmegyében két évig, és még tudtam valamit. S mondtam nekem ez elég. Nem lesz problémám az a lényeg, hogy jól gyónjék. Furcsa volt, hogy mondtam egy Miatyánkot, ök mondtak más Miatyánkot. Ök tudják a régi Miatyánkot, mi a második Vatikáni Zsinat elött volt, azt tudják most is. S mikor kellett mondani teljes szivemböl, akkor nem tudták,
}

keeping them at bay, yet if they are helped from outside, like we organized it it Pusztina or Lészped, they gladly attend. 
mondták románul, hogy, 'act de credinta'. Ök nem mondják, hogy teljes szivemböl, hanem töredelmesen, azt hiszem ök megtartották a régi imádságokat, s mikor mondjuk Isten bárányai akkor én válaszoltam, mert némán maradtak. Még régen volt, azt megtartották mi volt a liturgiába a második Vatikán Zsinat elött, de mi most fejlödött, most nem. "106 (36-50 years old church representative living in Hungary)

There are initiatives to introduce the Hungarian language to masses held in Bakó, and hopefully more worshippers could attend:

\begin{abstract}
„,most, hogy beszéltünk utoljára a püspökkel, mondta, hogy lesz Báko városba. Ott van egy nagy templom, s van a kicsi templom, a régi templom a Szent Miklós templom. Kicsi, de szép templom, hol be lehet vezetni a magyar misét, talán minél elöbb. "107 (36-50 years old church representative living in Hungary)
\end{abstract}

Conjunction is not only among Csángós (in general) and the representatives of the Catholic Church in Moldova, a more primary relation is given by the community and its religious leader, the local priest. Like all other relations, can be of three forms: good, bad or neutral. At first it seems that seeing the relationship as good or bad, is based only on who is asked. At a closer look might be obvious that those who are supporting the Romanian identity of Csángós are in good relations, and those favoring the Hungarian identity are in bad relations with the local priest. Situation is not that unequivocal. Data shows that relying on certain conditions a good relationship can be sustained regardless of ethnic positioning. Some respondents think that even if there is a bad relationship between the priest and the community, or the members of the Hungarian affiliated organizations, priests should not be condemned, they have to obey the bishop, they are members of a hierarchy, and the mechanism is ruled from the top. There are priests who are more open-minded, while others are stricter toward the introduction of the Hungarian language to schools and masses while other are totally against and use different means to make it impossible.

\footnotetext{
106 There were 2 or 3 old ladies, who said, that they don't speak Romanian at all, only in Hungarian and they were confessing like that. I said, that it is fine with me, because I was holding masses for two years in Hungarian at the diocese of Iaşi, and I still knew something. I said that that is enough for me. I won't have any problems with it, only to confess in order. It was strange, I said one Holy Father, they said a different Holy Father. They know the old Holy Father, which was prior to the second Vatican Synod, they know that one now too. When they had to say "from my heart", they didn't know, they said it is Romanian, that "act of faith". They are not saying "from my heart", they say contribution, I think they kept the old prayers, and when we said the Lamb og God I had to answer, because they remained silent. It was a long time ago, they kept what was in the liturgie priorly to the second Vatican Synod, but what evolved now, no.

107 The last time when we spoke with the bishop, he said that there will be in the city of Bákó. There is big church and a small one, the old church, the Saint Michael church. Small but beautiful church, where probably as soon as possible Hungarian masses could be introduced.
} 
„Vannak, akik nem prédikálnak rólunk, lehet velük beszélni és vannak olyan esetek, mint például ezelött két évvel, hogy a tanárokat pedofilnek meg szervkereskedönek prédikálta ki. Azért mondtam, hogy közöttük is vannak jobbak és kevésbé jobbak, mármint a mi szemszögünkböl. A Iaşi egyháznak a terjeszkedése az azt hiszem most már közismert mert nem csak Magyarországra hanem a világ bármelyik sarkára ahova a Iaşi egyházmegyéböl elmentek emberek, oda a Iaşi püspökség megpróbál papokat küldeni, hogy hát tartsák bennük a románságot meg a hitet. "108 (younger than 35 current leader living in Moldova)

The first two lines of the previous quotation make reference to the event which occurred in Nicoreşti that triggered the correspondence of László Tőkés and Petru Gherghel presented before.

While there are examples of good relations, there are many conflict situations as well. Examples when the priest said that the Csángó dialect is not Hungarian, they don't speak the correct Hungarian nor the correct Romanian, and so on.

„Most is van oljan amikor a pap kiprédikálta, hogy: nu e limba materna la voi, nici nu vorbiti romaneste, nici nu vorbiti ungureste, ce inseamna asta ca nyervilodtam si gresilodtam, astai romaneste, de ce stricati limba romana? Astai ungureste? Eu stiu cum se spune pe ungureste, voi nu vorbiti ungureste. Puneti mina si invatati." ${ }^{109}$ (older than 51 employee living in Moldova)

Other examples are showing how the priest tried to convince parents or children that attending Hungarian classes is bad, or at least useless and that opting for Hungarian education is very much disapproved by him:

„Voltak olyan dolgok, amikkel szembe kellett nézni a családnak, pl. a bátyám felvételizett nyolcadik után, az egyházi iskolába, szemináriumba, Szeredába, azzal nem is lett volna probléma önmagában, hogy kiborul, csakhogy a vasárnapi nagymisén, ahol mindenki ott van kiprédikálta, tehát a templomban téma lett és kijelentette, hogy amig ö ott pap, a bátyám az oltárra nem teszi fel a lábát. Ez azért ott... hogy mondjam ... az emberek annyira fölnéztek a papra, s annyira kisiten, hogy Úr Isten aki olyant csinál ami nem jó ... Nagyon

\footnotetext{
${ }^{108}$ There are who are not preaching about us, we can speak with them and there others like two years ago, when teachers were preached as pedophiles and organ dealers. This is why I said, that among them as well there are better ones and worse ones, at least from our point of view. The expansion of the church of Iaşi, I think is well known, because the Episcopate of Iaşi tries to send priests not only to Hungary but to every corner of the world where people went from the diocese of Iaşi, so to maintain Romanian identity and faith in them.

${ }^{109}$ Even now there are cases when, let's say that the priest preached that: is not our mother tongue, we don't speak Romanian, and we don't speak Hungarian either, because what does it mena that "nyervilodtam" and "gresilodtam" (words are in Romanian with Hungarian affix) this is Romanian, why are you spoiling the Romanian language? Is that Hungarian? I know how to say in Hungarian. You don't speak in Hungarian. Put your minds and learn.
} 
lesütött szemmel kellett a szülöknek kijönni a templomból, meg nekünk is közlekedni a faluban. " 110 (younger than 35 employee living in Hungary)

The conflicts among local priests and the community, the role and power of the religious leaders is often discussed in ethnographic aspects. Narratives referring to church and priests were used in order to see the role played in the Csángó matter and in the elite development. Local priests often speak up against the introduction of Hungarian language to churches and schools. Hearing stories when people were scared or threatened in order to estrange them from the Csángó matter is not rare.

„Aztán kellett csináljak más csoportot, azokat engedte. Ha mennek velem táborba Magyarországra, akkor nem bérmálja meg. Elszórta azokat is. Aztán ez a gyerek melyik furulyált eljárt velem táborba és nem bérmálta meg. Azt keresi, hogy égesse az embereket, a gyerekek ne jöjjenek az én programomra. Sokszor kimondott ilyent a misén is." ${ }^{\text {"111 }}$ (older than 51 current leader living in Moldova)

In other cases, although with different opinions, discussion and communication can be done with the priest (mostly younger ones). It seems that identity and selfidentification is an important topic for educated Csángós, regardless if they were educated in Romanian or in Hungarian.

„Azt mondja - sunteti primul om cu care discut si recunoaste asta. S mondom - ati mai discutat cu cineva? Azt mondja: da, deobicei batrinele daca aduc discutia atunci tace si nu zice nimica. Hát mondom annyit ütték hogy nem szabad így, nem szabad úgy hogy szegények nem mondnak semmit. Jó az úgy, ahogy mondja a primar s a pap. Van egy iljen mondás nálunk, hogy ha a primarval s a doktorval s a papval sohase kéne bajad legyen, akkor nagyon jó lenne. " ${ }^{112}$ (older than 51 employee living in Moldova)

Concluding that local priests have conflict only with those who are proclaiming the Hungarian aspects of the Csángó culture and how the Hungarian language should be

\footnotetext{
${ }^{110}$ There were some situations that the family had to confront, for example my brother applied after the eight grade, to a clerical school, seminary, in Cskíszereda, the fact that he was freaking out, only that on Sunday on the mass, where everyone was present, preached and stated that until he is a priest there, my brother won't put his foot on the altar. This there ... how should I put it ... people are looking up to the priest, he is such a smallgod, that Oh God, if one does something disliked by him. ... Was very shameful for parents to leave the church and for us as well to move around in the village.

${ }^{111}$ Then I had to make another group, and he let those. If they go trips in Hungary with me, then he won't let them confirm. He sent them away too. Then this child, who was playing on the flute, went to excursions with me, and he didn't confirm him. He seeks to harm people, to children don't come to my program. On several times said this during masses as well.

${ }^{112}$ He said - you are the first with whom I discuss this and admit. I asked-Have you discussed it with others as well? He said yes, usually older women if I bring up the topic, listen and don't say a word. I told him, they were so often hit that this is no allowed, that is not allowed, they rather don't say a thing. It is $\mathrm{OK}$ as the mayor and the priest says. There is a saying in our parts, that if you were never to have problems with the mayor, the doctor and the priest it would be very good.
} 
(re)introduced in the everyday life and its institutions is not accurate. In some cases those who are agreeing with the Romanian identity of Csángós, aren't getting any support either.

"În unele cazuri chiar preoții cu care mă ințeleg foarte bine şi sunt chiar de al lor pot să spun ... ei, este, este destul de grav. Merg în unele comunități să scriu o monografie, datoria mea este să merg la preot şi la primar. Unii preoți te ajută, alții nu. "113 (36-50 years old current leader living in Moldova)

Both - those with Romanian and Hungarian identification - agree that priests played an important role in the assimilation of Csángós to the Romanian majority. While some see that as a negative thing, through which Csángós lost their original culture and identity, others think that by their acts priests served the community at their best, providing them the opportunity to have a better life.

„Am pierdut mult pentru că nu am avut acest intelectual, înainte cine erau intelectualii catolicilor în secolul 18 - 19, chiar început de 20 prima jumătate chiar, nu erau decât preoții, cei din vârf. Preoții care şi ei trebuia să-şi apere prestigiul lor. De aceea s-a ajuns aici pentru că practic, preoții care au fost atunci în episcopia de Iaşi a trebuit să facă față presiunilor externe, din păcate. [...] Catolicii ar fi fost excluşi din societate cum au şi fost de altfel, până la 1859, nu au erau recunoscuți, erau considerați străini. Prin urmare ei nu puteau avea pământ, nu puteau accede la funcțiile publice, nu puteau să aibă un cuvânt în societatea în care trăiau la urma urmei de o sută, două sute, trei sute de ani depinde când au venit strămoşi lor. Faptul că şi-au pierdut o bună parte a legăturilor cu strămoşii nici măcar la Şimleu nu mai ajungeau la pelerinaj o mare majoritate dintre ei, lucrul acesta a contat mai puțin în măsura în care, majoritatea românească le-a recunoscut ca egali.,"114. (36-50 years old current leader living in Moldova)

\footnotetext{
${ }^{113}$ In some cases even the priests with whom I am in very good relation, may I even say that I am on of them ... well is difficult. I go in some localities to write a monograph, my duty is to go to the priest and to the mayor. Some priests help you, others don't.

${ }^{114}$ We lost a lot, because we did not have this intellectual, before who were the intellectuals of Catholics, in the $18^{\text {th }}-19^{\text {th }}$ centuries, even the first half of the $20^{\text {th }}$ century, no one else but priests were those on the top. Priests, who themselves had to defend their prestige. This is why things ended up like this, because practically priests who were in the episcopate of Iaşi had to face the external pressure, unfortunately. Catholics would have been excluded from society, as there were otherwise, until 1859, they were not recognized, were considered strangers. As a consequence they could not have any land, could not access public functions, could not have an opinion in the society in which they lived for more than one hundred, two hundred, three hundred years depending on when their ancestors came. The fact that they've lost a good part of their connections with their ancestors and a great majority of them didn't even get in pilgrimage to Simuleu Ciuc, this thing mattered less if the Romanian majority recognized them as equals.
} 


\subsection{Identity or ethnic self-identification of the Csángó elite}

Fischer sees three characteristics of newer works focusing on ethnic identity, one that ethnic identity is over and over reinterpreted by every generation instead of being a fix characteristic transmitted through generations and can influence even if is not taught consciously. Second observation refers to the case of minorities as Fisher explains is not the same being Chinese-American and being Chinese in America. "A process of assuming an ethnic identity is an insistence on a pluralist, multidimensional, or multipersonal concept of self: one can be many different things, and this personal sense can be crucial for a wider social ethos of pluralism." (Fischer, 1986:196) The last observation refers to the search for a sense of ethnic identity and coherence.

The topic of Csángó elites and the Csángó elite as a group as well, is very layered and divided. One of the most obvious division lines is ethnicity or ethnic identification. Regardless of historic facts and debates focusing on the origin of Csángós, there is a fact that needs to be taken in consideration, namely that the majority of Catholics from Moldova during the national census declared themselves Romanians. There are different estimations - from 60 to 80.000 people - regarding the proportion of those who still speak Hungarian or a dialect of it, but actual, precise numbers are not known. Using the estimation given by Tánczos Vilmos in 1997 approximately 62.000 people still speak Hungarian. (Tánczos, 1997) Speaking a language and identifying with that specific ethnicity still might differ. It is a community that has its interests, goals and representatives and as such its conflicts of interest and competitive representatives.

Márton Demse, a Csángó writer, wrote that all Csángós have one name in the community and another one in the official papers. By looking at the names of Csángós, one could easily decide that they have Romanian names, yet using Hungarian names or nicknames is quite usual in the everyday life in the village.

„Így járja itt az élet. Mindenkinek más a neve itthon és más a hivatalban. Hogy honnan jövünk és merre megyünk önmagunk erejéböl vagy merre visz az ár, ezt kár vitatni. Választ a létkérdésekre úgyse találunk. ${ }^{, 115}$ (Demse, 2007: 161)

Identity and identification is very complex - some might say uncertain - in the case of Csángós, with many layers and with a change of identity over space and time. This might be related with the so often affirmed fact, that the Csángó society has/had no

\footnotetext{
115 This is how life goes here. Everyone has a different name at home and another one at the offices. Is useless to discuss from where we come and where do we go from our own power or where the tide. Answers to the questions of existence we won't find anyway.
} 
intelligentsia, and the past, the history always proved to be very much uncertain and arbitrarily interpreted.

"Nagyon sokan úgy látják, hogy sokkal gyengébb bennünk a magyarérzet, mint a magyarországi magyarokban, a románok felöl szintén, tehát ök sem értik, hogy sem a románérzés nem eléggé erős, de sem a magyar. Nincsenek emlékmüveink, valahogy ezt így tudnám, nagyon, nagyon röviden összefoglalni, nem vonzódik a történelmi események megemlékezésére. Mikor iskolában voltunk, voltak fontos dátumok, a vallási ünnepek, és az iskolán belül voltak fontos dátumok a történelmi pillanatok, megemlékezés, a mit tudom én. Nem éreztünk soha semmi különöset, tehát most is, nem tudnának ki venni a házból egy ilyen esemény miatt. Ez valahogy hiányzik belölünk, ez egy nem létezö épitmény a csángó közösségben, tehát valahogy ez nem épült fel, nincsenek meg a múlt pillérei. Ha mondjuk román kultúrában gondolkodom igen, akkor mindjárt tudok mondani egy pár írót, aki engem meghatott, tehát nyomot hagyott, most, hogy ismerem a magyar kultúrát, ugyanúgy tudnék mondani. De a saját közösségemböl nem jut eszembe semmilyen név, kit kéne emliteni, kit tisztelünk, kiröl emlékezünk meg? Nincs." ${ }^{\text {"l6 }}$ (younger than 35 former leader living in Moldova)

Identity of Csángós is often seen by scientists as an intermediate, as mixed “neither Romanian, neither Hungarian”. (Simon \& Péter, 2004) Simon explains that identity "is shifting" according to the situations in which one is encountered and that actors are visualizing it by the "under-or upper communication" the most important group specific characteristics such as their language and religion. (Simon, 2005:25)

The difference among ethnicity and citizenship is not understood or applied for many in Moldova. Several people seem to agree with a statement that was often used by Romanian nationalists: If one lives in Romania one is Romanian, and as such has to speak and think as a Romanian. This mentality is often embraced by Csángós as well yet a differentiation from others from neighbouring villages can be also observed.

“Én kiemelem, hogyha mondják valakiröl, hogy román, és én csángó vagyok az nem helyes szerintem. Mert, román vagyok én is, mert Romániába élek, és román mindenem, és gyerekkorom óta úgy tudom, hogy mi vagyunk a ... nem is tudom mi sosem mondtuk

\footnotetext{
${ }^{116}$ Many people think, that Hungarian consciousness is much weaker in us than in Hungarians from Hungary, from the side of Romanians similarly, they can't understand either, that Romanian consciousness isn't strong enough, but Hungarian either. We don't have monuments, very very shortly this is how I could conclude, the celebration of historic events is not attracted. When we were in school, there were important dates, religious holydays, and in school too there were important dates, historic moments, celebrations, I don't know what. We never felt anything special; even now, they could not take me out from the house for an event like that. This somehow is missing from us, this is missing construction in the Csángó community, so, this wasn't built up, the pillars of past are non-existent. If I think in Romanian culture then yes, I can instantly say couple writers, who touched me, left a mark; now that I know the Hungarian culture I can also say some. But from my community no name pops into my mind, who se should mention, who we respect, who do we commemorate.
} 
magunkról, hogy csángók vagyunk. De tudom, hogy róluk, úgy mondtuk, hogy ök alák. ",117 (36-50 years old employee living in Moldova)

At the same time members of the older generation who learned in Hungarian schools during the communist regime as well, proudly admit their Hungarian identity. Even those Csángós who assume Romanian identity know that they are different from the surrounding Orthodox Romanians, yet their differences weren't something well established and solid. They are different in religion but while "the other" were named as "oláh" (an older name of Romanians) they did not name themselves as such. The concept of Csángó identity gets more complicated as beside Csángó, Csángó-Hungarain identifications like Csángó-Romanian also appear and gain ground. While some think that this concept is absurd - since Csángó implies Hungarian and as such one can’t be Hungarian-Romanian - others think that this concept was created to stand for a phase of assimilation, or because some are ashamed to show jointly belonging and origin.

"Itt szégyellik a csángó nyelvet, szégyellik az édesanyjukat, az édesapjukat." 51 current leader living in Moldova)

“egyelöre még nem beszélhetünk csángó-románokról, csak összezavart csángókról. Zavarban élö csángókról beszélhetünks az, ami sajnos nagyon nagy tömeg." ${ }^{119}$ (older than 51 current leader living in Moldova)

“Nem az, hogy román csángók hanem, aki már elvesztette ... vagy inkább románnak gondolja magát az nem mondja, hogy román csángó hanem azt hogy román. Ez egy kitalált fogalom a román csángó, ahogy nagyjából kitalált fogalom a csángó magyar is vagy magyar csángó. Ugyanolyan mintha azt mondanánk, hogy székely román vagy székely magyar. " 20 (younger than 35 current leader living in Moldova)

Representatives of Romanian organizations focusing on Csángós and Csángó culture think that public opinion has to be changed and the variety of opinions should be publicly known. It seems that while locally the multiplicity of identities do exist, on an international level it seems that Csángós are known as a Hungarian minority and this is disliked by some.

\footnotetext{
${ }^{117}$ I underline that, if someone says about one that is Romanian and I am Csángó, that is not correct. Because I am Romanian too, because I live in Romania, and romanian is all I have, and since my childhood I know that we are the ... I don't know, we never said about ourselves, that we are Csángó. But I know that about them, we said that they are Romanians.

${ }^{118}$ Here the Csángó language is ashamed, they are ashamed of their mother, of their father.

119 So far we can't speak about sángó Romanians, only about confused Csángós. We can speak about Csángós living in confusion and that is a very large mass.

${ }^{120}$ Not that, Romanian Csángó, that is if one already lost ....or more likely thinks him/her self as Romanian doesn't say that is Romanian csángó, but only that he/she is Romanian. This, Romanian Csángó, is an invented concept, just as more or less the Csángó Hungarian or Hungarian Csángó concept is an invented concept. It is just as if we would say that Romanian Székler or Hungarian Székler.
} 
"Eu cred totuşi că la nivelul Instituțiilor Europene ceva s-a schimbat, pentru că personal am fost la Biroul de Informare a Consiliului Europene şi am purtat discuții cu alți raportori. Şi asta a fost un semn bun, pentru că eu am înțeles că iată pot fi chemați şi alții să-şi spună punctele de vedere, care sunt altele decât cele cunoscute până atunci. Cred că în urmă cu un an şi ceva, dacă nu-s doi după integrarea României, un raport a apărut în care pentru prima dată cred, apar şi ceangăai care ar fi maghiari să spunem, dar şi ceangăii care ar fi români să spunem. Nu rețin eu exact formularea. Aşa că totuşi ceva s-a intâmplat şi dacă acest lucru au fi continuat, şi la nivel de dialog, atunci eu cred că am putea face un pas mai departe, pentru că eu nu cred că Europa ar trebuii să spună cine sunt ceangăii, sunt români sau maghiari asta este treaba istoricilor şi doar a lor. ",21 (3650 years old current leader living in Moldova)

The goal of this chapter is not only to present the identity of the Csángó elite, but also how they see the identification and identity related issues of their communities. "A moldvai magyarság, az értelmiség kialakulásában a csikszeredai program volt a legmeghatározóbb program. Elinditotta az embert, meg integrálta a magyar nemzetbe, ami azt hiszem nagyon kellett nekem is meg hát azt hiszem, hogy nem csak nekem, hanem a moldvai magyarság azon részének, aki érzi a másságot magában, de ezt nem tudja megfogalmazni. Én nekem az az érzésem, hogy a magyar nemzetbe való integráció rendbe tenné ezt a kérdést, legalábbis velem ez megtörtént, nem mindenkire, hanem arra nézve, aki érez affinitást ezek iránt.",222 (36-50 years old employee living in Hungary)

When speaking about the ethnic identity of Csángós, scientific literature often says that Csángós are not identifying themselves by ethnicity, but by religion. Not speaking the modern literary Hungarian and being different from the Orthodox majority, self identification was and still is difficult.

“Ez olyan furcsa mikor, rossz érzés ... akkor inkább hagyatak békén, nem vagyok se román se magyar, ö evvel megszabadul, ö katolikus és kész. Mert a katolikusok itt Moldovában, csak a magyarak voltak katolikusok. Itt nem volt református vagy egyéb. Itten, aki román az

\footnotetext{
${ }^{121}$ I thing though that at the level of European Institutions something changed, because me personally have been at the Council of Europe Information Offices and had discussion with other reporters. And this was a good sign, because I understood that it is possible to call others as well, to speak up their points of view, that are others than those known so far. I think a year and something ago, if not two after the integration of Romania, a report appeared I which for the first time I think, appear Csángós who might be Hungarian to say so, and those Csángós who might be Romanian to say so. I don't recall the specific formulations. So something did happened and if this thing would have continued at the level of dialogs as well, then I think we could make a step forward, because I don't think that Europe should decide who are the csángós, are they Romanian or Hungarians. This is the duty of historians and only theirs.

${ }^{122}$ In the development of the Hungarian from Moldova, the intellectuals, the program from Miercurea Ciuc was the most determinant program. Launched on, and integrated into the Hungarian nation, which I think I needed very much too, and I think not only to me, but to that part of the Hungarians from Moldova, who feel the otherness in him/her self but can't formulate it. May feeling is that, integration into the Hungarian nation would solve this question, at least this happened with me, not to everyone, but to those who feel affinity toward these things.
} 
ortodox, aki magyar volt az katolikus, de vannak még úgy is, hogy asszimilálódtak. Egy mukkot nem tud magyarul, de a katolikusok azt mondják rá, hogy magyar, de ö nem tud magyarul. ... Össze volt keverve a hit az etnikummal." ${ }^{2123}$ (older than 51 current leader living in Moldova)

Referring to self-identification, generational differences can be observed. The older generation, especially those who participated to the Hungarian teaching organized by the Magyar Népi Szövetség always knew - to some extent - that they are different from the Orthodox majority not only religiously, but by ethnicity as well. They knew that they are Hungarians, yet this knowledge wasn't sustained by any scientific referring to origin, history - proofs, facts. While ethnicity rarely is a topic of discussion - just like today in many families - being Hungarian was that obvious for several Csángós as Romanian identity is for the majority of today's generation.

"Most, hogy apám sose tette fel magának azt a kérdést, hogy ö magyar-e vagy roman, ö azt tudta, hogy magyar és viselkedése meg beszédjei az úgy volt, hogy én magyarnak nöttem fel. Mondjuk anyám szerette volna, hogy eltünjek a tengerben, ne legyek az a feteke bárány és akkor néha még veszen vala nekem valami olyan öltönyt, hogy úgy mutassak ki, mint egy kiemelkedettebb gyerek a faluból és felöltöztetve mondta, hogy jaj te ha igy meglátnak azt gondolják, olyan szép román gyerek vagy. S erre az apám, menj el te Rózsa ne butáskodj, hogy akarsz te juhból kecskét csinálni? "'124 (older than 51 current leader living in Moldova)

Undertaking Hungarian identity creates public conflict, debate or discussion situations. Convincing the representative of the church or the legal system that one considers him/herself of Hungarian origin and of Hungarian ethnicity is not easy and occasionally results in extreme actions, such as changing religion.

„Mondom, az egyik Secusnak, honnan tudja maga, hogy román, mert maga nem román. Azt mondja, hogy értem ezt? Hát a nagyapám, az apám, az öseim mind románul beszéltek, anyám is. Na, mondom, látja s akkor maga román. Azt mondja: persze. Ezek szerint csak az a román aki igy nött fel? hát persze! Nézze, akkor én mi vagyok, anyám, apám, nagyapám, s az öseim mind magyarul beszéltek. Akkor én is román vagyok? Hát ezek, ezek

\footnotetext{
${ }^{123}$ This is so strange when, is a bad feeling ... then rather leave me alone, I am not either Romanian, either Hungarian, with this he/she escapes, he/she is Catholic and that's it. Because Catholics in Moldova, only Hungarians were Catholics. There weren't Protestants or others here. Here, Romanians are Orthodox, Hungarians were Catholics, but there are others who assimilated. Doesn't know a word in Hungarian, but Catholics say that he/she is Hungarian, but he/she doesn't know Hungarian. ... Faith and ethnicity were messed up.

${ }^{124}$ Now, that my father never raised the question, whether he is Hungarian or Romanian, he knew that he is Hungarian and his behavior and talks were like that, that I grew up as Hungarian. So to say, my mother wanted me to disappear in the sea, and not to be the black sheep and then she bought me some new suits, so I can look like a child who emerged from the village and dressed up, and she said, that one sees me like that will think what a nice Romanian child you are. And to this my father said, don't be silly Rose how do you want to make a sheep from a goat?
} 
elmagyarosodott románok. ... De normális, mondom. Hát ha a katolikusok mégse azok, mondom neki, hát akkor leszek én olyan vallású, aminek a statútum s a törvény szerint magyar az anyanyelve. A katolikusok románok is lehetnek, lehetnek lengyelek is, de, pl. a reformátusoknál törvény szerint az istentisztelet magyar nyelvü lehet csak, román nincs. Áttértem szépen, tanuk elött református hitre, mert ott volt egy református gyülekezet Bakóba, ahova jártak vagy 10-20-an Erdélyböl oda származott valakik. Jenei Tamás volt a lelkész ott. Jenei Tamásnak az apja, Jenei Sándor vitte háború előtt Nagyenyedre Sütő Andrást gimnáziumba. Ezzel a Jenei Tamással jó viszonyba voltam én. Bakóba öt is nagyon sokat diszkreditálta a Securitate, és mivel én vele jó viszonyba voltam, akkor engem megint. ${ }^{\prime \prime 25}$ (older than 51 employee living in Hungary)

Some think that after the severe assimilation of previous times, today convenience and the hope of an easier life makes the assimilation. It is much easier and more convenient to be Romanian than Hungarian and those who are seen as having relations with Hungarians are envied and/or disapproved. One teacher of the Hungarian education once urged the parents to speak in Hungarian with their children, because now there is no need of the secret service to do the assimilation, parents are doing that. One parent responded that while she is fighting them to use Hungarian with children school teachers are asking to speak in Romanian because children are not using the proper Romanian language. It is quite a general opinion in Moldova that only one language can be used with a child, otherwise he/she won't learn any of them well enough. During fieldwork the strangest case was when someone learning in Budapest told me that his parents are speaking among themselves in the Csángó dialect with them in Romanian while the children - all studying in Hungary - speak the literary Hungarian among themselves.

Generational aspects in identity can be observed. Several members of the older generation think that while they don't say anything about the identity of the community, or not even their neighbors they are certain of their Hungarian identity, and the culture

\footnotetext{
${ }^{125}$ I say, to one Secus how he knew how do you know that you are Romanian, because you are not Romanian. He says that to understand this? Well, my grandfather, my father, my ancestors spoke Romanian and my mother too. Well, I say, and then see themselves as Roma. He says yes. So the only way the Romanians who grew up in? of course! Look, I am what I am, mother, father, grandfather, and my ancestors are speaking Hungarian. So I'm Romanian. Well they are, they Magyarized Romanians. ... How normal, I say. Well, if Catholics are not that, I say to him, then, I will have a religion, which by statute and law is of Hungarian language. Catholics can be Romanians, also Poles, for example for the Reformed, I say,the language of teh worship can be only in Hungarian, not Romanian. I changed in front of witnesses to the Reformed faith, because there was a Protestant congregation Bako, where couple 1020 people coming from somewhere from Transylvania were going. Tamás Jenei was the pastor there. The father of Tamás Jenei, Sándor Jenei took before the war András Sütő to Aiud to High School. I was in good relationship with this Tamás Jenei. In Bacau he was often discreditated by the Securitate, and because I was on good terms with him, me as well.
} 
representing their ancestors is something that has to be preserved. In the same time, language and cultural heritage is losing significance when it comes to the young generation.

"Még durvábban, mint kommunizmus alatt, mert azt gondolom, ha akkor volt egy eröszakos nyomás, akkor az emberek megpróbáltak ellen állni, és akkor az identitás ... most is sokkal hamarabb megjelenik az öregeknél az, hogy ök magyarok, mint a fiataloknál. De a fiatalok nem érzik most azt a kényszert, hogy ök bizonyitsák, hogy ök magyarok, föleg a nagyon fiatalok, akik már csak románul tudnak. "226 (older than 51 current leader living in Hungary)

While for the parents of today, the primary language was Hungarian and they learned the Romanian only in school, for their children the first language, the one they use confidently - regardless that they speak in Hungarian in the family - is Romanian.

“Látom a saját fiamról, hogy magyarul beszélünk vele, de neki az elsődleges nyelv akkor is a román, mert reggel nyolctól délután négyig óvodában van, románul szolnak hozzá és amit tanul mind azon a nyelven tanulja. ... kilencvenig volt közösségi élet, önmagától szervezödött közösségi élet mely 90 után megszünt. ... már nem élnek közösségi életet, nincsen olyan kapcsolat amilyen volt régen, hogy a szomszédok együtt jártak kapálni, együtt jártak takarni, s több ilyen. Megszünt. De ennek a megszünésével megszünik az a természetes folyamat, hogy a szájhagyomány révén ismert kultúra énekek meg balladákat átörökítik. ",27 (younger than 35 current leader living in Moldova)

Children brought on trips to Hungary are often speaking among themselves in Romanian while they use the Hungarian only/mostly to communicate with the Godparents from Hungary and other non-Romanian speakers.

As one teacher told me during Hungarian classes they occasionally have to translate almost everything to Romanian in order to be understood by children. The teacher thinks that in the optimal case, Csángós should be taught to find their places in Romanian institutions as well, and as such need to use the Romanian language at a high level, and to have scientific knowledge in Romanian language. Others say that if so, this is not the duty of Hungary and if Csángós are not strengthened in their Hungarian

\footnotetext{
${ }^{126}$ Even more roughly than during communism, because I think that if there was violent pressure, than people tried to resist, and then identity ... even now faster appears at older people that they are Hungarians than at young ones. The young do not fall to the pressure to proove that they are Hungarians, especially the very young ones who only speak Romanian.

${ }^{127}$ I can see about my son, we speak with him in Hungarian but his first language is still the Romanian, because from eight in the morning to four in the afternoon he is in kindergarten, he is spoken to in Romanian and all he learns, learns it in that language ... until nineties there was a community life, a community life that was self-organizing itself and ended after 1990 .... there is no community life, there are no such relations that were priorly, that neighbours were going together to hoe, to cover, and many others. It ceased. As this ceased, ceased the natural process, that culture, songs, ballads are perpetuated through oral tradition
} 
identity their education should not be founded by Hungary. Paying heavy millions of forints in order to ensure Hungarian experiences is not worthwhile for anyone, for supporters and for Csángós either.

It was a surprise to see that even teachers of MCSMSZ - working in the Hungarian teaching program - are speaking in Romanian with their children, or if they do speak in Hungarian or Csángó dialect the child answers in Romanian. Several children said that they feel uncomfortable if they have to speak in Hungarian, yet they like to attend Hungarian classes, understand everything in Hungarian and if they have no other choice they do speak the language.

Those who graduated from Hungarian universities are strengthened in their Csángó-Hungarian identity, and their opinion towards Moldova and the events occurring in Moldova, are much more modern and moderated.

“Azt mondani, hogy a Moldvában élo” katolikus közösség, talán ez a helyes megfogalmazás, ök mindnyájan magyarok, ilyen nincs. Van olyan csángó származású ember, aki románnak vallja magát és ezt tiszteletbe kell tartani. Én is tiszteletbe tartom, nyilván ugyanakkor elvárom azt, ha én csángó magyar vagyok, és magyarnak vallom magam, akkor elismerjék az én identitásomat, és ha kérek valamit, és ha kér a csángó magyar közösség - nem hobbiból, vagy bármilyen beteges megfontolásból - magyar misét, akkor azt gondolom, hogy óhatatlanul engedélyezni kéne. Sokat beszélünk csángókról, csángó nyelvröl, itt szerintem le kellene szögezni egyszer és mindenkorra, hogy amikor csángóról beszélünk akkor magyar származású, magyar gyökerekkel rendelkezö népcsoportról van szó, akik nem beszélik az irodalmi magyar nyelvet, hanem a magyar nyelv egy archaikusabb változatát. ",28 (younger than 35 church representative living in Hungary)

There is an obvious conflict that is originating from ethnic self-identification. Families seen as Hungarians are often accused that they identify themselves as Hungarian, only because they have personal interest in it, they are receiving support and gifts from Hungary. The topic of identity of Csángós is always central in any discussion referring to this community. Who is Hungarian and who is Romanian is an omnipresent topic of discussion.

\footnotetext{
${ }^{128}$ Saying that the Catholic community living in Moldova, probably this is correct formulation, are all Hungarian, is not true. There are people of Csángó origin who declares him/her self Romanian, and this must be respected. I respect that, obviously in the same time I expect that if I am csángó Hungarian and I declare myself Hungarian, than my identity should be recognized, and if I ask something, if the csángó Hungarian community - not by hobby, or any sick consideration - Hungarian masses, then that inevitably I think should be allowed. We are speaking a lot about Csángós, about Csángó language, here itt should pointed out once and for all, that when we speak about csángós than we speak about an ethnic group with Hungarian origin, Hungarian roots, who doesn't speak the literary Hungarian language but a more archaic version of the Hungarian language.
} 
„Soha nem hallottam a faluban, hogy legyen ez a vita. A forradalom után mikor hozták a támogatásokat, akkor lassan, lassan kiderült, hogy van egypár család ki magyarnak tartják magukat, és halottam, hogy ök már régen is azt mondták, hogy magyarok. Miután látták, hogy ebböl is lehet jól élni, és nem kell sokat dolgozni, akkor, de nem mind. Azok kik akkor voltak most is azok vannak, 5-6 család kik mondják, hogy magyarok, ök is kapnak valami támogatást. "229 (36-50 years old church representative living in Hungary)

Conflict can be seen among family members as well. Working in/for the preservation of the Csángó-, the Hungarian culture can be disapproved by spouse, by mother in laws, by brothers, etc. "who are directly angry because of it".

"Ezzel csak bonyolitod az életedet, de másképpen nem lehet, ha a megmaradás a cél. Én azt nem tudnám megcsinálni, hogy letagadjam bárki elött es hogy én magyar származású vagyok, én azt érzem, ez bennem van, nem betanitott valami." "130 (older than 51 employee living in Moldova)

Assuming Romanian or Hungarian identity can be done in both directions. Opting for any of them with the goal of having an easier life or to have higher odds of success seems to be a conscious option.

“Az ottani elit, hát mondjuk értelmiségi, az teljesen be-, elrománosodott. Annyira érdekelt emberek, hogy behódoltak teljesen azért, hogy nekik könnyebb legyen, ne bojkottálják; akkor is a másik román kollegák között, megvan mindig ez az ellentét, még annak ellenére is, hogy románul beszél, románul tanít, akik ortodoxok azok a katolikusokat egyáltalán nem tudják megemészteni. ",131 (36-50 years old employee living in Hungary)

Self identification is often related to information. Transylvania had a strong effect on the identity forming processes. All interview subjects who studied in Transylvania recalled that it was a turning point. While in the Csángó village identity was not a topic of discussion - for some it was obvious that they are Hungarian, for other the Romanian identity was self-understandable, others considered religion as something that defines them - they remember that they heard for the first time the concept of Csángó, or

\footnotetext{
${ }^{129}$ I've never heard this debate in the village. After the revolution when aids were brought, slowly became clear that there are couple families who consider themselves Hungarian, and I've heard that they said that before that they are Hungarian. When they saw that is possible to live well from this, and doesn't need a lot of work, then, but not too many. Those who were then are now too, 5-6 families who say that they are Hungarian and they receive some aids.

${ }^{130}$ With this you only complicate your life, but is not possible in any other way if remaining is the goal. I could not do that to deny in front of anyone that I am of Hungarian origin, I feel that, it is in me, it isnot a thought thing.

${ }^{131}$ For the elite from there, let's name intellectual, is totally assimilated. Are so much people of interest, that totally surrendered in order to make it easier for themselves, for not to boycott them, even them among Romanian colleagues, there always exists that contrast, even if speaks in Romanian, teaches is Romanian, those who are Orthodox can't accept Catholics at all.
} 
realized that Romano-Catholic is not the same as Romanian Catholic when they went to Csíkszereda. They found out that there are other places where people speak the same language as they do. Being strengthened in the Hungarian identity can be done in almost any stage of life, as one interviewee noticed the shift in identity at his mother when they moved to Transylvania.

„Egyébként is magyarul tanult meg kiskorában, neki ez természetes volt, csak hát ő csángó volt, egy ilyen kiközösített, megvetett csángó, aki a senki országához tartózik, de ahol neki muszáj, meg kellett tanulni románul, beilleszkedni és együttélni. [...] Csak ö csángó volt, Erdélyben megerösödött benne az a tudata, és talán picit megnyugtató is volt hogy hát ö magyar és igenis ez nem is olyan rossz dolog. Nem kell szégyenkeznie, nem kell lesütnie szemét, nyugodtan vállalhatja, szóval ez egy ilyen nagyon erös formáló tényező volt.",l32 (younger than 35 employee living in Hungary)

Hungarian teaching especially higher education in Hungary not only that should strengthen Csángós in their Hungarian identity, but the original goal was that they will return to Moldova and use their accumulated knowledge there. If they fail to do so, in many cases Csángós who settled in Hungary, and some of the supporters as well, think that they disappointed their community:

“Az identitás nem csak odáig tart, hogy megyek magyar iskolába, hanem ott kéne befejezödni, hogy nektek vissza kell menni a gyökereitekhez, amikor elvégeztétek az iskolát. Erre is egy kicsit megtanitani öket, mert akkor az történik, hogy Magyarországon maradnak akkor örülünk neki, hogy ök jobban élnek de cserben hagyják az ottaniakat és mi ehhez segédkezünk ha így csináljuk. “133 (older than 51 current leader living in Hungary)

A shift toward Hungarian identity can be seen among migrants as well, mostly at those who once worked in Hungary. Living in Italy or Spain in several cases is worthier to "be Hungarian" than to "be Romanian".

“Olaszországba például nagyon rossz hírük van a románoknak, esti híradó van róluk, így lehet, hogy egy kicsit érdek is, de inkább magyarnak vallják magukat. Hát Rómában tudom, akinek 4 oo ezer eurós háza van, kifejtette nekem, hogy itten másféle szellem van, de ö román meg minden, s nézem, hogy a gyerekkel magyarul beszél. Úgy hogy van, aki tudja.

\footnotetext{
${ }^{132}$ Anyway in childhood learned to speak in Hungarian, it was natural for her, only that she was Csángó, an outcast, despised Csángó, who belonged to the country of no one, but where she compulsorily, had to learn in Romanian, to fit in and live along. [...] Only that she was Csángó, in Transylvania the knowledge that she is Hungarian and that isn't such a bad thing was strenghtened, and a bit was comforting too. Should be ashamed of, should not cast down her eyes, she can safely confess, so that was a very strong identity forming factor.

${ }^{133}$ Identity doesn't last only until to going to Hungarian school, but should end there that you should go back to your roots when you graduated this school. They should be taught this to a bit, because otherwise it happens that they remain in Hungary, and we are happy for them having a better life, but they are letting down people from there and we are assisting to this, if doing so.
} 
Akik itt voltak azok magyar identitásúak, az olaszoknak is elmondják, hogy ök Romániából vannak, egy olyan környezetbe születtek, hogy eleve katolikusok, amennyire értik az olaszok a viszonyokat ilyen szempontból. "134 (older than 51 former leader living in Hungary)

In August - is vacation in Italy, and all guest workers return to Moldova - Csángó villages are crowded with foreign cars, from 10 cars at least seven are with Italian or Spanish numbers, and in these times Hungarian speaking is also more frequent.

"Ha felmentek a falun tele van autókkal, mert haza vannak jöve a fiatalok. Sokat lehet hallani, hogy magyarul beszélnek szépen, többen, mint ezelött. Több magyar szót hallasz

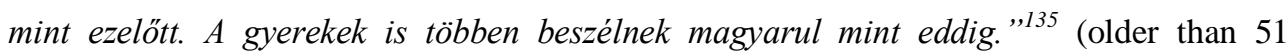
employee living in Moldova)

Interviewees pointed out that instead of speaking about neither Romanian nor Hungarian, in the case of elites, identity is certain and does not depend on any situation, yet elites do agree that for the community ethnic identification does have a situational aspect as Simon observed. (Simon, 2005) On the other hand instead of speaking about the neither Hungarian nor Romanian ethnic identity of Csángós, I think that their identity includes both. Identifying as one or the other does indeed depend on situation and in doing so one doesn't deny the other, simply considers one aspect as more important or more accurate in that specific situation. Elites on the other hand are firmly convinced about their Hungarian or Csángó Hungarian identity just as many other elites are clear in their knowledge of their Romanian identity. Mixed identity can be also interpreted using Lucassesn's imposed ethnicity (Lucassen, 1991) conept if saying that by accepting the self differentiation from so called real Hungarians (those living in Hungary and in Transylvania) and real Romanians, Csángós are opting for a Csángó identity that can be seen as neither Romanian nor Hungarian, still both.

\footnotetext{
${ }^{134}$ In Italy there is a very bad opinion about Romanians, there are evening news about them, so it is possible that a little bit from interest, but they are more likely to declare themselves Hungarian. In Rome I know someone who has a house of 400 thousand euro, and explained me, that here is a different mentality, but he is Romanian and everything, and I can see that with the children speaks Hungarian. So there are some, who know. Those who were here (in Hungary) are of Hungarian identity, they are telling to Italians as well, that they are from Romania, and they were born in a milieu that they are Catholics, as the italians understand relations from this point.

${ }^{135}$ If you go up in the village it is full with cars because the young came home. Many can be heard that they speak Hungarian nicely, more than before. You can hear more Hungarian words than before. More children are speaking in Hungarian then until now.
} 


\subsection{Romanian - Hungarian self-identification as a conflict}

When it comes to conflicts among those with Hungarian and those with Romanian identity one can rely mostly on personal stories and experiences, acknowledging that deducting conclusions and generalizing them is not necessarily valid.

The first story is dated during the communism, when one member of the Csángó elite was regularly persecuted by the secret service.

„Ha jött valaki hozzám, akkor már jött is a Securitate s a rendőrség. Hát 5,6, 10 év alatt vagy 7 házkutatás volt nálunk. A könyveimet mind elvitték. Domokos Pál Péternek volt egy nagy könyve, most is megvan, hogy Édes hazámat akartam szolgálni, azt az öreg elküldte nekem, s míg hozzám jutott Bakóba, másfél évet bolyongott Erdélyben. Volt egy olyan ének gyüjteményem, tulajdonképpen az is a Domokos Pál Péteré volt, Rezeda, azt is elvitték, még volt egy olyan, hogy Kájoni János, Katolikus kancionáré, 1600 évekböl. Azt lefoglalták mint nemzeti kincs, ,face parte din patrimoniul cultural national” (a nemzeti kulturális örökség része). Mondom, hát miféle „cultural national”, mikor ez magyar. Akkor is, azt mondja, Románia, mondom, ez csak Romániában van, de semmi köze a románsághoz. Mert ez a Kájoni János, azt mondja román ember volt. Meg is jelent, miután elkobozták nekem ezt a könyvet, egy két évre megjelent Kájoni Jánostól egy román vastag könyv, Ion Caianul. Hát én láttam azt a könyvet, de nem olvastam el soha." ${ }^{\prime 36}$ (older than 51 employee living in Hungary)

Second narrative aimed a child, and indirectly the entire family, and all those who support the introduction of Hungarian language to schools.

„Felemelték a fiamat jut eszembe, csak másodikoska vot és feltették a székre, nálunk úgy vót a szokás, hogy mikor valameljiknek ünnepelték a napját akkor feltették a székre úgy lábra. Oljan tanitója vót meljik nagyon jó tanító amúgy, nagyon jól bánt velük, nem verte nem semmi, jól ment neki a tanitás, a gyermekekvel jól megértette, az ö osztályai mind jól érvénysültek, mind jól kitanultak. Állitták ugye fel a székre s ünnepelték s énekelték neki La multi ani cu sanatate- mit tudom én kinált egy-egy cukorkát, bombonét nálunk mondjuk. $S$ azt mondja egyszer felállitották nagy mérgesen a székre, ö azt gondolta szegényke, hogy most öt es megakarják ünnepelni. S egyszer mondani kezdte: nézzétek meg jól, -uitați-vă bine la el, părintii lui sunt vânzători, vânzători de țară, trădători. Így a gyermekeknek,

\footnotetext{
${ }^{136}$ If someone came to me, the Security and the police was there too. During 5,6, 10 years there were 7 perquisitions at our place. They took all my books. Pál Péter Domokos had a big book, I still have it, titled "Édes hazámat akartam szolgálni" (I wanted to serve my sweet country), the old man sent it to me, and until it arrived to me in Bacau for one and a half year was wandering in Transylvania. I had a collection of songs, actually that belonged to Pál Péter Domokos too, called "Rezeda", they took that too, it was another one János Kájoni: "Katolikus Kancionáré" from the years of 1600. Those were all seized: national treasure, "it is part of the national cultural patrimony". I asked what kind of cultural national, when this is Hungarian. Ven so, he said, Romania, I said this is only in Romania but has nothing to do with the Romanian nation. This Kájoni János was Romanian he said. After they confiscated the book from me, after one or two years it was published a thik book by Kájoni János, Ion Caianul. I saw that book, but never read it.
} 
másodikos gyermekeknek. Úgy megvolt ijedve, s haza jö és kérdezi hogy-mămică ce inseamnă trădător- mondom há hol halltad te azt, oljant beszéltek nektek, miljen trădător, gondoltam valami történelmet mondtak. Akkor sírt és mondta, hogy felállitották egy székre és azt mondták hogy - părinții lui trădători - ce ați făcut, ce trădător, ce inseamnă. "l37 (older than 51 employee living in Moldova)

Third recital is referring to the customs applied at funerals. Explains how the habits changed, how Hungarian singing at vigilance was changed to Romanian and how these are connected to the church.

\begin{abstract}
„92. vot legutolján mikor még igy magyarul énekeltek a halottnál, azért hogy azután megholt az öreg Deák ameljik vót a faluba s jött kettö iljen ifiú, még húsz esztendösek sem vótak. A pap azokat kitanitatta hogy tanuljanak meg orgonálni hogy legyen ki orgonáljon, legyen Deák a faluba s azok mivel az eskolába ólául tanultak, tudtak azok beszélni magyarul meg minden, de nem tudtak olvasni, nem tudtak iljen régi öreges énekeket. Akkor hogy egyszerüsitse a dolgot a pap azt mondta, hogy mondjátok csak tük románul, mert ez mért baj, ök énekeljenek otthon, itt énekeljék mit énekelünk a templomban mert azok es szent énekek, nem muszáj azt tartani az ottanit, a régit, az nem annyira fontos. Az Isten érti ólául. Azt mondta, hogy ha asszonyok énekelnek a virrasztáson akkor azok vigyék temetni es. Úgy határozta meg, hogy ö nem viszi el temetni s nálunk az oljan baj, nagy baj, nem baj hanem nagy baj. Nem lehet, hogy a pap ne vigyen el ha meghottál. Most már sokan megvannak halva az öregekböl, azokból kik énekeltek, mert most úgy van, hogy odajö a Deák mellé ki a paptól van, s elmondják pontosan mit mondanának a misén, hamar egy tíz perc alatt. Legfeljebb ha elmondják a Rózsafüzért, de azt sem mostanában, azt maradnak ott az asszonyok és énekelnek, de inkább románul mert románul értik. "l38 (older than 51 employee living in Moldova)
\end{abstract}

\footnotetext{
${ }^{137}$ I remember that theyraised my son, he was only in the second grade, they lifted ona chair, the custom was that when someone was celebrating his/her birthday they lifted on a chair. Had a teacher who was a good teacher after all, treated them well, wasn't beating them, teaching went well, made it clear for children, his/her classes prevailed well, all were well educated. They were lifted to the chair and were celebrated and sang for them - Happy birthday to you - I don't know, offered a candy, or bonbon as we calle it. He said, that angrily was lifted on the chair, he though the poor thing that they want to celebrate him. And started to say, that: look well, his parents are sellers, country sellers, traitors, like that to children of second grade. He was so scared, came home and asked, mommy what doesit mean traitor, I asked from whom did you heard that, spoke about that to you, I thought they were speaking about some history. Than he cried and said that was lifted on a chair and told that, his parents are traitors, what have you done, what traitor, what does it mean.

${ }^{138} 1992$ was the last time when there were Hungarian singing at the deads, because when the old cantor died who was in the village and two young ones, they weren't even twenty years old. The priest taught so they can play on the organ, so there would be someone who plays the organ, so there would be a cantor in the village, and those were learning in Romanian in the school, they knew to play in Hungarian and everything but could not read, they didn't know any of these old songs. Then to simplify things the priest said, that you should just say it in Romanian, because why is this a problem, they should sing at home, here they should sing what we sing in the church, those are holy songs as well, it is not necessary to keep those ones, the old ones, is not that important. God understands in Romanian. Said that, if women are singing on the watch than they should make the burial too. This is how he determined, that he won't make the burial, and this is such a problem, big problem, not problem, but big problem. It is possible that the
} 
Fourth story is presenting a conflict among a child enrolled in the Hungarian teaching in Csíkszereda and the police, the justice system in Bákó, the excuse was the lost of ID card of the child.

„Bementem és mondtam, hogy elvesztettem a személyigazolványomat és szeretnék újat igényelni. A rendör rám kérdezett, hogy Szeredában tanulsz vagy Bákóban? De így direkt ... Pillanat alatt fölmértem a helyzetet, hogy mit akar megtudni és tudtam, ha azt mondom, hogy Szeredában, akkor meg fogom szívni, nem gondoltam, hogy annyira, de meg fog szívatni, ha meg azt mondom, hogy Bákóban, akkor sima ügy lesz, nem fogok nagy problémát csinálni magamnak. És nem tudom belém ütött akkor egy ilyen nagyon, elötte soha talán, de akkor az elsö ilyen dac, nyakasság, nem érdekel csak azért is megmondom neki, én már annyit izéltem én már pofont is kaptam a moldvai iskolában, hogy mért szólalok meg magyarul, bevallom. Ez kb. három pillanat volt, amig átfutott rajtam és döntöttem és mondom Szeredában, de még így kihúztam kicsit magam büszkén, mondom Szeredában. Nahát ennyi kellett, teljesen elvágtam magam ... felsorolta a feltételeket, hogy lehet új személyit csinálni, és mondta, hogy jöjjek vissza egy hét múlva. És visszajöttem egy hét múlva és akkor kérte, hogy adjak be egy kérvényt, beadtam egy kérvényt, kérte, hogy jöjjek vissza egy hónap múlva. Visszamentem egy hónap múlva, kiderült, hogy nem jó a kérvényem. Csináltak egy másik kérvényt, legközelebb nem volt jó a fényképem. És akkor meg akartak büntetni, mondtam, hogy nem fogok büntetést fizetni, mert nincs pénzem. Tehát akkor döntsék el, adnak személyit vagy nem. Hát nem adnak, adnának, persze az nem lehet, hogy nem adnak, akkor változtassunk a dolgon nem elvesztettem, hanem ellopták.... Minden procedúra kezdödött elölröl. Akkor mivel nem vagyok 18 éves, egy felnöttnek be kell jönni velem, akkor következö alkalommal nagytatámat be kellett cipeljem Bákóba, hogy ott jelen legyen, hogy igen, az unokája ... és már úgy egy év eltelt lassan, és akkor már rájöttem, hogy arra játszanak, hogy én minden bizonnyal kimegyek Budapestre tanulni és arra játszottak, hogy ne kapjak személyit, mert akkor nem tudok útlevelet csinálni. ... Mindig mondtak valami mondvacsinált ürügyet és akkor húzták egy év három hónapig a személyimnek a kiadását. ",139 (younger than 35 employee living in Hungary)

priest doesn't buries you if you died. Now many from the old ones who were singing are dead, because now those sent by the priest go near the cantor and say exactly they would say on the mass, quicly in ten minutes. At most they say the Rosary, bot not even that nowadays, then the women remain and sing, but mostly in Romanian because they understand in Romanian.

${ }^{139}$ I went in and said that I lost my personal ID card, and I would like to ask a new one. The policeman asked me, where do I study In Miercurea Ciuc or in Bacau? Directly like that ... In a second I measured what he wants to know and I knew that if I say that in Miercurea Ciuc, then I will have problems, I didn't think how badly, but I will encounter problems, and if I say that in Bacau then all will go smoothly, I will not create any problems to myself. I don't know what, a sort of, never before, the first defiance, it didn't bother me, just for spite I am going to tell, I hasd so many, I was even slapped in the face in the school in Moldova because I was speaking in Hungarian, I will confess. This was about three seconds until I though it over and I made a decision and I said, that In miercurea Ciuc, straightened up, proudly. That is all there was to it, I made it impossible to me ... enumerated all the conditions, how can receive a new IDcard and he said that I have to come back in one month. I went back after a month, revealed that my request wasn't good. They made another request, next time I went back my photograph was bad. Then wanted to punish 
Not all meetings among Romanian and Hungarians (or those with Romanian and Hungarian identification among Csángós) results a conflict situation. The conflict is more acute among the representatives, the advocates of the „two sides”. As suggested earlier the two approaches can be found in the scientific works as well. Romanians started to show scientific interest towards Csángós. As one interviewee, representative of a Romanian organization noted, previous disinterest was due to not knowing the language spoken by Csángós.

"A început şi partea românească să scrie, partea românească, partea cercetării româneşti, care a neglijat această comunitate din punctul meu de vedere. Cercetarea românească a neglijat această comunitate pentru că nu ştia deloc, nici graiul, nici limba maghiară şi atunci nu e de competența noastră, î̀ lăsăm pe ceilalți, respectiv pe cercetătorii maghiari să facă cercetarea. Ceea ce nu este corect, nu mi s-a părut corect.,"140 (36-50 years old current leader living in Moldova)

As the interviewee was studying for a period in Transylvania, acknowledges that professionally it was very important to learn the Hungarian language. Knowing the literary Hungarian and not only the Csángó dialect later made it possible to read the works of Hungarian scientists. Furthermore, in order to form an opinion, one has to know the views of others as well, whether he agrees or disagrees with them. While scientists from "both sides" are familiar with the works and opinions of the others, communication among them is only at a declarative level. Conferences are organized, but mostly separately and the representatives of the "other side" are not invited.

me, I said, that I will not pay any punishment, because I have no money. So they can decide if they give me an IDcard or not. So they are not giving, they would give, obviously it can be that they are not giving, so let's change the story is not lost but stolen. ... The entire procedure started all over. Then, because I'm not 18 years old, a grown up has to come with me, so next time I had to drag my grandfather to Bacau, so he can be present and say that I am his grandson ... and it was almost a year when I realized that their plan was that I almost certainly was going to study in Budapest, and they planed to not give an IDcard, because then I can't make a passport. ... They always said some trumped-up pretences and they pulled the release of my ID card for one year and three months.

${ }^{140}$ The Romanian part started to write too, Romanian part, the Romanian scientific part, which neglected this community as it concerns me. Romanian investigation neglected this community because did not know the dialect, nor the Hungarian langue and then it was not at their competence, and the let other, respectivel Hungarian researchers to do the investigations. What is thing is not fair, it did not feel right. 


\section{Elite Portraits}

\section{Motto:}

„A birodalmak növekedésével, $s$ az erőviszonyok bonyolódásával a legcsekélyebb kérdés körül a politikai tények oly kusza hálózata szövődik, hogy a ,jelenkori történelem “ valószínüleg mindenki számára a veszélyes tények és erők kibogozhatatlan öserdeje. Mit csinálhat a magánember, vagy akár a politikus, ebben a tömkelegben? Nyilván aligha mást, mint amit a szegény vándor az öserdöben: bukdácsol, kerülgeti a fákat és bozótokat, óvja életét - vagy nemzete életét - ahogy tudja, megy hol jobbra, hol balra, merre lehet, s nem az elérhetetlen csillag után, mely a távolban elötte ég: mert ha azt követné, betörné homlokát. Az irástudó is ily szegény vándor, magánéletében: de ö egyszersmind kalauz. Neki is bukdácsolnia kell, s kerülgetni az akadályokat jobbra és balra: de ö egyszersmind vállalta azt a tisztet, hogy folyton szem elött tartja a Csillagot. Ö is tudja, hogy a Csillag elérhetetlen. De mégis csak a Csillag az, ami e földi utakon irányt jelez. Aki egyenesen feléje megy, betöri homlokát és elpusztul. De aki végkép elveszti szem elöl, az eltéved és céltalan tömkelegbe fullad. ",141

(Babits, 1928)

In this subchapter the goal is to present the elite with their own words, their own worries, thoughts, experiences and everyday happenings ${ }^{142}$. The selection of the subjects was somehow subjective as such the aim was to create a parallel among those who live in Hungary (migrated and settled) and those who are in Moldova (missed the migration or returned) at least where is possible. In some cases - where possible - the comparison (which lacks all qualitative or measuring aspects) is done among representatives of the Hungarian and Romanian identity or self identification. Beside the mentioned goal to try to draw a parallel among Moldova and Hungary there was another aspect when selecting the subjects, those are presented that are often mentioned as elites and are well representing - with their life paths - their groups. Most of the elite members can be classified in several of these categories. Arbitrary as they are, these categories and the personal life paths, the stories behind the concepts are nicely bringing closer the research field, with its actors and concerns.

\footnotetext{
${ }^{141}$ Babits Mihály (1928): Az írástudók árulása, Nyugat, 18. szám

${ }^{142}$ In order to keep - as much as possible - the anonymity personal details and tracking data were dismissed, but even so some characters might be traced back and recognized by the members of the Csángó community.
} 


\subsection{The pathfinders, the intellectuals of several political regimes}

The first portrait (older than 51 employee living in Hungary) is of a Csángó writer who lives in Hungary, graduated in Széklerland as a teacher, worked in different schools and theaters; published several articles and essays. Was often persecuted by the Romanian Communist Secret Service (called Securitate) and changed his religion as a sign of protest to Reformed, known as a religion of Hungarians. Is a member of the generation which took part in the Hungarian education in Moldova, organized by the Hungarian Populist Movement. He remembers that in the first two or three weeks there were two Romanian teachers in the village, after which in the first four classes they had teachers brought from Transylvania. The Hungarian Populist Movement was very active at the time; Hungarian teaching was organized with more or less success in almost every Csángó village. He considers that organizers of the Hungarian teaching did not took in consideration that several teachers from Transylvania were Reformed which is still something different, something strange among Csángós:

„A csángó lelke világába a reformáció az valami szakadár féle, valami istentelenség, akik nem tudták a keresztet és a templomot úgy, ahogy a katolikusok tisztelik és áhitják, ezeknél egész más volt. Aztán rájöttek ők is akkor elkezdtek járni templomba, de a nép akkor is tudta, és nem tudták megérteni. Még most is vannak, nem tudjak megérteni mi az, hogy reformáció, református egyház."

In the fourth grade the „world changed again” when the communist party led by Gheorghiu Dej, liquidated Hungarian schools from one day to the other changing the language of education to Romanian. Priorly not using the Romanian language at all, recalls this change as a very difficult process. The only Orthodox (meaning not Hungarian) in the village was the family of the blacksmith; they were Gypsies who knew the Hungarian language as well. In the following years he went to school in a neighboring village, where he was studying with a scholarship, but even so learning wasn't easy. Having some land, meant education was no excuse, from an early age they had to work at the farm and around the house, had to feed the sheep, the cattle, etc. He remembers that because of these duties he could not go to school only in November,

\footnotetext{
${ }^{143}$ In the spiritual life of csángós the Reformation is a sort of schismatic thing, something pagan, who don $1 \mathrm{t}$ know the cross and the church, how the Catholics are respecting and yearning, at these it was totally different. Then later they realized it and started to go to church, but the people already knew and they could not understand. There are still who can't understand what the reformation is, the reformed church.
} 
just to find out that either catches up in one month, or is missing one year and can enroll only in the following September. Wanting to catch up in one month, until Christmas, he was asked whether he has the required books and notebooks:

\begin{abstract}
„Nincs ... akkor honnan legyen nekem könyvem? A falubeli fiú, aki járt az 5 osztályba, neki volt, mert vasutas volt az apja s jó módban éltek, hát az apám állami gazdaságba dolgozott, állat gondozással foglalkozott, az anyám otthon velünk, az öt éhes szájjal kínlódott, küszködött. No, hát azt mondja nekem ez a vasutas fia - ö nagyobb volt vagy egy évvel vagy kettôvel, mint én - ha te kihozol este egy veder bort a legényeknek adunk pénzt s megveszed a könyveket. Loptam a pincéböl egy veder bort mikor apám, anyám aludt, kivittem." "144
\end{abstract}

After buying the books, kept them in secret, hidden in the hay in the attic. Having a scholarship meant a lot, even now, after several decades he remembers all details.
„Három hónapra 90 lej, 17 lejjel lehetett venni egy pár bakancsot. 1,5lej volt egy pár zokni
... Első dolog volt, amit megvettem, azt hittem királyi viselet, egy tréning nadrágot meg egy
tréningruhát s egy pár bakancsot s az elsö zokni mit megvettem, piros zokni volt. Hát az tetszett nekem. ",145

The scholarships were taken by his father, as the family was very poor; he recalls this as a high psychological trauma. In his life story school and education had a major role, remembering and presenting all stations. He initially planned to learn in a military school in Cimpulung, but going to school was not a priority for his parents:

\begin{abstract}
„Hát az anyám állapotos volt az öcsémmel, nem engedett el. Ahelyett, hogy engedett volna egész nap kapálni mentünk. Hiába magyaráztam én az anyámnak bármi iskolát, tudatlan asszony volt s nem tudta felfogni, hogy az mit jelent. Majd elmész jövö héten. Én mondtam az nem úgy müködik: hányszor prédikál húsvétra a pap? Azt mondja, hogy egyszer. Ezt is csak egyszer lehet egy évbe mondom. Valamit értett ö, de ... nem. "146
\end{abstract}

From a villager learning in Bákó, he heard about the opportunity of studying in Udvarhely to be a teacher. Easily decided, that he wanted to follow this track. After

\footnotetext{
${ }^{144}$ No I don't have... At that time from where could I have. The boy from the village who was in the 5th class, he had, because his father was a railwayman and they lived in good conditions, my father were working in state care, working in animal cares, my mother at home with us, struggling and tormented with five hungry mouth. So, the son of the railway man told me - he was older with one year or two than me - if you bring tonight a bucket of wine for the boys, we give you money and you can buy the books. I stole a bucket of wine from the basement when my father, mother was sleeping and I gave it to them.

14590 Lei for three months, with 17 leis you could buy a pair of boot. 1,5 lei was a pair of socks. The first things I bought, I thought was royal wear, a set of training suit, a pair of boots and the first pair of socks that I bought were red socks. That is what I liked.

${ }^{146}$ My mother was pregnant with my brother, she did not allow me to go. Instead of letting me, we went to hoe all day long. Vainly I was explaining her any schools, she was a nescient women, couldn't understand what that was. You'll go on the following week. I told her it's not like that: how many times is the priest holding a mass for Easter? She said: once. This can be done also once in a year, I told her. She understood something, but ... no.
} 
graduating he went to Vlahița (Szentegyháza) to teach, but there the wife of the priest having only a baccalaureate was teaching, so he ended up in a nearing village, where he was teaching for not even three months, being taken in army. After the army he should have returned to teaching in the village, but not knowing about this possibility he returned to Moldova. He remembers sadly that if he would have returned then, his life would've turned out differently.

For seven years he worked in a locality of Bákó County, from where he was expelled because of teaching Romanian history in a "too Hungarian spirit". The next job was as a material purchaser at the drama theater in Bákó, then he made a course of technical director, and one of stage props. Later he tried to work in a school, but at the inspectorate being known as someone not needed in the education system he was fired after two weeks. Another reason for firing him was that he wrote articles in which his Hungarian point of view was central.

He returned for one month to the theatre after which he made another course, and worked as a locomotive driver for 15 years. Publishing several articles in different journals such as Korunk, Igaz Szó, keeping regular contacts with Hungary, having often visitors from foreign countries, got him into the vision of the Romanian Secret Service. Having friends like Pál Péter Domokos, a famous ethnographer, who worked on the music literature of Csángós, and collected folk songs, or the painter Lajos Udvarhelyi, who also collected folk songs, or the rector of the Sorbonne University from whom he found out that there are many books referring Csángós at the Sorbonne, András Sütő, Sándor Kányádi, György Beke with whom he worked together, were all disadvantages in the eyes of the Secret Service. Being arrested in as many towns as he visited, after a while he had to ask for permission in order to leave Bákó. In less than 10 years about 7 perquisitions were done in his house. Another important moment in his life - very strange among Csángós - can be seen as a consequence of these perquisitions. Changed his religion, becoming Reformed saying that was the only religion that had to be accepted as Hungarian by ethnicity, having no Romanian members:

„A református egyház volt az egyedüli egyház magyar nyelven, mely összetartotta a népet, mert a katolicizmus ugyebár mindennyelvüséget értett, öt nem érdekelte a nemzeti tudat, nyelv, hanem csak az egyház. ",147

\footnotetext{
${ }^{147}$ The reformed church was the only one in Hungarian language that holds the nation together, because Catholicism was multilingual, was not interested in national consciousness or language, only the church.
} 
Being kicked out from the communist party was a momentous event in his life and he still remembers all the details.

\begin{abstract}
„,Kirúgtak a pártból, mert, mikor jöttem át a határon 81-ben, akkor nálam találtak valami kéziratokat. „Behozható-e a kulturális lemaradottság”, Erdélyt viszonyitom a moldovai kultúrához, csángókhoz. Egy másik volt, hogy „Nyílt levél”, az egyik volt iskolatársamhoz. A jegyeket a feleségem vette meg és ö nem ismerte hol megy a vonat. Éppen egy olyan vonatra vette, amelyik Arad felé ment, mert én rendszerint mikor mentem, mindig Kolozsváron kiszálltam, bementem a szerkesztöségbe, a Korunkhoz, a Napsugárhoz. [...] Azt mondták irásos dokumentumokat próbálok a határon átcsempészni. [...] 1981. január 17.-én elvették a pártkönyvemet, a városi pártbizottságnál, és az indok az volt, hogy papokkal összejátszok, és árulom az országot. ",148
\end{abstract}

The goal was - as he recalls - to imprison him. Between 81 and 90 he was outside of the party, he continued to write, and work with the TV. In 89 after 11 years of prohibition, when leaving Romania was nearly impossible, he came to Budapest. Since that, he lives in Budapest where he feels that life is much calmer, nobody calling him as "bozgor", or "man of no country", but here he is seen as Romanian.

„Ne mond, hogy én román vagyok, mert én magyarabb vagyok, mint a magyar, mert a moldovai magyarok minden viszontagság közepette megmaradtak lelkükben, hitükben magyarnak, de itt és sok helyen nem. Ahhoz képest itt én lelkileg megtaláltam az életem mivoltját, anyagilag viszont nem. Anyagilag én ott jobban éltem, de nem azt jelenti, hogy én most perlekednék. Tehát én, amit tettem, amit irtam lehetöségeknek megfelelöen itt vagyok, itt dolgozom, nyugdijba mentem, kész. Közbe még dolgozom ezt azt, aztán így jól érzem magam. Nem kívánkozom egyáltalán Romániába."149

\footnotetext{
${ }^{148}$ I was kicked out from the party because when I was passing the border in 81 , they found some manuscripts with me "Can we bring in the backward culture "in which I compare Transylvania with the culture of Moldova, of the Csángós. Another one was "Open letter", I was writing it to a former schoolmate. The tickets were purchased by my wife and she did not know where the train was going. She bought a ticket for a train that is going through Arad, because usually when I went, I stopped in Koloszvár, I went to the editorial, to the Korunk, the Napsugár. [...] They said I tried to smuggle written documents through the border. [...] 17th of January 1981 took my partybook at the city committee, the cause was that I collaborated with priests and I am selling the country.

149 "Do not say that I am Romanian, because I'm more Hungarian than Hungarians, because Hungarians from Moldova amid all the hardship remained Hungarians in their soul and their faith, not like here and other places. Though, spiritually I found the meaning of my life here, but economically not. I lived there better financially, but it does not mean that I am now brawler. So what I did, what I had written, according to the possibilities I am here, I work here, I retired, and that's it. I work this and that in the meantime, and I feel good. I don't feel like going to Romania at all. ”
} 
The second portrait (older than 51 current leader living in Moldova) is of a Csángó poet who lives in Moldova, he was the first who registered an organization that aimed to serve the interests of Csángós, to preserve the culture and heritage of Hungarians from Moldova. Beside writing and publishing he teaches Hungarian language at his own foundation.

He starts his life story by underlining that in their village in his childhood everyone spoke Hungarian, and as such identity and identification was obvious. Self identification was always clear but as he recalls their identification by outsiders was not that unified, than again maybe that is what made him search for the origin of Csángós and the truth about their past:

„Én tudtam, hogy én ki vagyok, csak az lepett meg, amikor azt mondták nekem, hogy én bozgor vagyok, és amikor tudtam, hogy bozgor vagyok, akkor a bozgorok azt mondták nekem, hogy csángó vagyok, amikor kijöttem Magyarországra azt mondták, román vagyok. S akkor az ember elkezdi keresni önmagát." ${ }^{\text {150 }}$

As many others, wanted to prove that he is Romanian, but all proof and data he found were leading to the fact that Csángós are Hungarians. At that moment he decided that there is no reason to fight against logic and proves. He realized that adhering to political principles, theories, realities, not realities and masses is not compulsory either.

In the first years of school he learned in the village, he was one of a few who could speak Romanian, he knew the language because his mother worked as a midwife and worked in a hospital in Bákó.

They had no Hungarian books in the village only religious ones that were kept by older people. He remembers that once going to school he was asked by an older man if they learnt Hungarian in school, to his answer that Hungarian is a language that can't be written only spelt, he was asked whether he wants to learn Hungarian. It was important and even after several years he remembers those teachings. Later he realized that it was not only about one kid, but it was a method to teach Hungarian and to inherit and to pass forward the language skills.

„Akkor kaptam az elsö magyar könyvet, egy imakönyvet. Tudod a Mi Atyánkot? Igen! Mond
csak el a Mi Atyánkot. Aztán rájöttem, hogy ez egy módszer volt, hogy amelyiket
kiválasztották, hogy valamennyire tudta a faluban a nyelvet. Ez egy módszer volt, kellett

\footnotetext{
${ }^{150}$ I knew who I was, I was only surprised when they told me that I am a "bozgor", and when I knew that I am a bozgor, the bozgors told me that I am Csángó, when I came to Hungary, I was told that I am Romanian. And then one starts to search for himself.
} 
tudja a Mi Atyánkot és a Mi Atyánkban értelmeztették azokat a különbségeket, ami volt a román abc és a magyar abc közt.",151

He was interested in Hungarian books but all they could get were mostly religious ones, then at the end of the '60s having his uncle in the Hungarian Populist Movement he received a book published in Romanian, titled A Magyar Ellenforradalom. (The Hungarian Counter-revolution) Since then, he started to be interested in Hungarian history, legends, and so on, but books like that were nowhere to be found in Moldova and people were afraid to tell stories:

„Az emberek mindig féltek. Emlékszem, hogy jöttünk haza az erdöböl és az egyik asszony mondta a Kömüves Kelemen legendát és mondta, hogy elmondok nektek egy mesét, egy hosszú mesét egy ilyen legendát, de nehogy ti is mondjátok, mert ezért megbüntetnek. ... Nagyon érdekelt, mért büntetnének meg? ... mikor felnöttem ... jaj mondom ez Mesterul Manole, mi a fene? ... Persze, mikor nagyobb lettem akkor vettem észre, hogy mi az egész furcsaság, mért is félt az asszony." 152

Having the same legend in Hungarian and in Romanian as well, and both nations considering as their own induced conflict situations that he understood only later, just like he understood only later why it was punishable to say the legend in Hungarian, it was a statement of self-identification.

Learning on his own the Hungarian language had some negative aspects as well, especially spelling was difficult he remembers one case when his father asked him to read something in Hungarian:

\begin{abstract}
„Mondta az apám, nahát, olvass nekem es. $S$ az öreg mindig megunta, mert nekem a kiejtésem az irodalmi nyelven nagyon rossz volt. $S$ akkor, ha a szavat láttam és tudtam, hogy az apám nem érti meg, állitottam én magamban hogy nem érti meg, akkor én rögtön átforditottam a csángó értelemben, ugye, nem mondtam, hogy szomoritja, mondtam, hogy köpöritja táté... úgy irja, itt köpöritja. ... És akkor mondta, fiam, olvassad, hogy írja, fiam. $" 153$
\end{abstract}

\footnotetext{
${ }^{151}$ Then I received the first Hungarian book, a prayer book. Do you know the Our Father? Yes. Say the Our Father. Later I realized that this was a method, through which they choose those from the village who knew the language somewhat. It was a method, had to know the Our Father and through the Our Father explained the differences between the Romanian and Hungarian ABC.

${ }^{152}$ People were always afraid. I remember coming home from the forest and a woman was saying the legend of Kőmüves Kelemen, and she said that I am going to tell you a story, a long story, a legend, but don't you dare to say it too, because you will be punished for this. I was very interested why would I be punished? ... when I grew up ... Oh, I said this is Mesterul Manole, what the heck? ... Surely when I got older I realized what is the strangeness, why was the women afraid.

${ }^{153}$ My father said, read to me too. And the old man was bored, because my pronunciation in the literary language was very bad. And when I saw a word, and I knew that my father wouldn't understand, I supposed in myself, that he wouldn’t understand, then I immediately translated in the Csángó meaning,
} 
It is important that the generation of his parents knew legends, knew history. In his generation language knowledge is totally different, using his words they "suffered for the Hungarian language”. His generation supposedly decided that knowing Romanian is a life important question, and in order to succeed in everyday life Romanian language has a greater priority than Hungarian language.

“Az a generáció amelikben én felnöttem az a generáció szenvedett a magyar nyelvért. Most gyerek korodban, ha valahogy, valamilyen módon érzed azt, hogy le vagy nyomva, téged nagyon érdekel hogy megtanuld a nyelvet, el is sajátitod valamennyire. Az az érdekes, hogy nem élünk a román nyelvvel, tehát az én generációm azért, hogy románul tudunk jól beszélni nem élünk a román nyelvvel. Magyarul beszélünk, érdekes módon a gyerekeinkben automatikusan ... nem kell elitélni a csángó embert, hogy románul beszél a gyerekének, ő nem bünös. Ö a gyerekkorában belenött valamibe."154

The generation of those who are young parents today, the importance of the majority language is even higher. Parents are speaking in Romanian to their children even if they are sending the young ones to him to Hungarian classes. The other aspect that turns parents toward Romanian language rather Hungarian is that everything that exists in Moldova and in Csángó villages is Romanian:

„Kinyissuk a TV-t az román, elmegyünk a templomba román, elmegyünk az iskolába román, kimegyünk a városba veszünk egy újságot, az román, ... imitt amott van egy Moldovai Magyarság, vagy most már az a csíki rádió, de hát az mennyihez jut el ... "155

so, I was not saying making him sad, I said, 'köpörítja' dad, ... it is written 'köpörítja'....And then he told me, son read it as it is written, son.

${ }^{154}$ The generation in which I grow up, that generation suffered for the Hungarian language. Now if in your childhood, if somehow, in some way you feel that you are pushed down, you are very interested to learn language, you even learn it somewhat. It is interesting, that we don't live the Romanian language, that is because our generation knows to speak well in Romanian we don't live with the Romanian language. We speak in Hungarian, in an interesting way in our children automatically ... should not condemn csángós, because he speaks to his kids in Romanian, he is not guilty. In his childhood he was growing in to something.

${ }^{155}$ We turn on the TV is Romanian, we go to church is Romanian, we go to school is Romanian, we go to the town buy a newspaper, is Romanian ... here and there you can find a Moldvai Magyarság, or now the Csíki Radio, but how many are reached by that ... 


\subsection{The young intellectual}

After the pathfinders, the intellectuals of previous times, a young writer and ethnographer (36-50 years old employee living in Hungary) who lives in Budapest is presented. She has published several books referring his home-village and their culture, getting her $\mathrm{PhD}$ in ethnography, researching religious aspects of the Csángó culture is the third portrait presented.

She was among the first who chose to study in Csíkszereda. Her parents didn’t want her to leave, but because of constraints and because she was so eager to go, finally permitted her to continue her studies in Transylvania. Having a father with great prestige it was almost obvious for the children to be good in school and to see further education as beneficial for their future. Older brothers graduated in professional schools or in theoretical school, having a baccalaureate. She continued her studies in Csíkszereda from the $7^{\text {th }}$ grade, she remembers having no idea about what she was enrolled to, but had only the motivation of leaving and learning.

„Egy nagyon elzárt településbe születtem. Gyakorlatilag én a tankönyvekből ismertem meg a külvilágot. Egyszerüen nem létezett külvilág csak belvilág, és ez a belvilág olyan nyomasztó volt, mert mindenki mindenkit ismert és már gyermekként is, amikor az ember 10 - 12 éves, beleszövödik a lelkébe, mert talán személyisége akkor még nincs hogy Isten mentsen meg a falu szájától. Ki sem nyitja az ember a szemét és ezt a fogadalmat, vagy kivánságot önmagával szemben megfogalmazza. Ez egyrészt a vágy a külvilág iránt és nyomasztás a belsövilág iránt. "156

She had no information at all about this town; not knowing that education would be done in Hungarian was just one example. She stresses that these so radical changes between unknown worlds, are often repeating themselves later too. The change from the home-village to Csíkszereda was similar with the change from Csíkszereda to Budapest. In Csíkszereda all children from Moldova were in a Csángó class. It is important to mention something that appears in several interviews:

„Mondanom sem kell, hogy ott tudtam meg, hogy én csángó vagyok. Én ezt a szót odáig nem hallottam, ezt a szót a faluban ma sem nagyon használják, ez egy teljesen új kifejezés, szerintem mi vittük be a faluba. Az idösebbek hallották ezt a szót, de mindig másokra

\footnotetext{
${ }^{156} \mathrm{I}$ was borne in a very isolated locality. I practically know the outside world from textbooks. Simply it dod not exist an outside world, only an inside one, and this inside world was so depressing, because everybody knew everybody and even while you were a child, when you are 10-12 years old it is woven in your soul, because probably he has no personality yet, that God save you from the mouth of the village. One doesn't even open his eyes and already makes the vow or desire towards himself. On one hand this a desire for the outside world and the depressing of the inner world.
} 
használták és nem önmagukra, a Kalagoriakra például, tehát akiknek a mi nyelvjárásunknál archaikusabb jellege volt, azokra mondták azt, hogy csángó. "157

Catching up with others of their age was very difficult and required special education and special teachers. Teaching children in the $7^{\text {th }}$ grade the $\mathrm{ABC}$, when the entire learning language changed from Romanian to Hungarian was a step needed to be taken not only by teachers but by students as well. Adolescence brought new successes and new failures. She remembers that being a Csángó teenager in Csíkszereda was easier for girls than for boys. The problems encountered then and there can be seen today in Budapest as well.

\begin{abstract}
„,nagyon - nagyon - nagyon nem volt pénzünk, semmi pénz nem volt, a fiúk ez alól nem kivételek, nekik még annyi pénzük sem volt, mint a lányoknak, mert azért a lányoknak az anyjuk dugdosott. A fiúk ... hát egy csángófiúval egy lány nem tud mihez kezdeni és ez a nehézség mondjuk, most is meg van, itt Magyarországon is, hogy az úgynevezett egzisztencia, ugye az számon kéretik, és egy tizenegyedik gyereknek született csángófiúnak miért lenne egzisztenciája. Még ha ö tíz éve dolgozik és spórol, akkor sem biztos, hogy kialakul valami vagyona és lehet, hogy albérletbe lakik és az életkörülmények teljesen megnehezitik a létét." 158
\end{abstract}

In classes 9-12 she was studying in a music class in Csíkszereda, where the emphasis was on subjects related to music, and all other materials were neglected by students and teachers too. After the baccalaureate she applied to the NEI - it is important to mention that while today for the 10 places there are about 3 applicants, then for 10 places 23 Csángós applied - where music school proved to be disadvantageous. Having low results on the baccalaureate in the NEI she was enrolled to be prepared for Teachers college. She remembers her first contact with writings of Saint Augustine and The Confessions, Dosztojevszkij, books and authors she never heard of. She discovered the beauty of reading and later the beauty of writing. Although she had the possibility to read in Csíkszereda as well, concentrating on music subjects they were just learning from textbooks and reading the actual novel, going to the library was

\footnotetext{
${ }^{157}$ I don't even have to say that I found out there that I am Csángó. Previously I never heard that word, this word in the village is not really used today either, it is a new concept, I think we brought it to the village. The older ones heard this word, but always used it to others and not themselves, for those from Kalagor, to those whose language had more archaic aspects than ours, they called those Csángó.

${ }^{158}$ Really - really - really had no money, we had no money at all, boys were no exception to this rule, they had even less money than girls did, because the mother of girls stick some to the girls. The boy ... well with a csángó boy a girl can not plan anything and this difficulty still exists, here in Hungary too, the so-called existence is accountable, and why should a csángó boy born as the eleventh one have an existence. Even if he is working and saving money for the past ten years he is still not sure that he has any wealth and is possible that he lives in a rented place and the life circumstances make his life much harder.
} 
totally missing from their, from her life. Writing, which has an important role in her life, was discovered mostly in that one year of NEI. Three important factors can be seen in her story telling that all together lead to the significance of this method of selfexpression. She felt the need of reflecting on her reading experiences, found a typing machine that she rented daily and the loneliness she felt while studying in NEI are the key factors that launched her on the track of writing.
„Aztán rögtön reflektáltam irásba ezekre az olvasmányélményekre, akkor ezeket küldözgettem mindig mindenkinek, hogy én miket olvastam, mert egyedül nem tudtam megemészteni. [...]
A NEI-ben volt egy olyan szoba ahol, lehetett kölcsönözni dolgokat, vasalót, irógépet, és én felfedeztem ezt az irógépet, mert még nem volt számítógép 97-be, és akkor mindennap kikölcsönöztem az irógépet. Már mindenki haragudott rám, hogy mindig nálam van az irógép, és akkor én nagyon élveztem, hogy én írok, irógéppel leveleket. [...]
Az, hogy magányos is voltam nagyon, a társaim azok könnyebben beilleszkedtek, eljártak bulizni, udvarlóik voltak, én teljesen más voltam ilyen szempontból. Imaközösségbe jártam, misére jártam, valószinüleg annyira nehéznek tünt ez az élet, hogy a vallás és az írás, fontos kapaszkodó lehetett. Az is érdekes, hogy sokuknak, volt segitöjük, vagy itt volt egy testvérük, vagy rokona, vagy nagynénje, különösen a pusztinaiaknak, vagy voltak ilyen, nagyon gazdag támogatóik." "159

Under the influence of her reading experiences she wished to study Philosophy, but still the baccalaureate was the measurement that was used in order to decide what education will be followed and not the evolution during the year. She started the Teacher Training College but soon realized that it is not the school and not the profession she would choose to opt for.
„Közben megismerkedtem Domokos Pál Péterrel, a lányaival elsösorban, Domokos Máriával és Erzsébettel és hát nekik elmondtam mindent, ami velem történt, rendszeresen jártam hozzájuk, tanítottak engem, felolvastunk, Arany János irásaiból kellett felolvasni minden ebéd után. Nagyon érdekes volt. Tanítottak hangosan beszélni, artikulálni,

\footnotetext{
159 Then I immediately reflected in writing to these reading experiences, and I sent these to everyone, what I was reading, because on my own I wasn't capable to digest it. [...]

In the NEI it was a room from where it was possible to borrow things, iron, typewriter, and I discovered this typewriter, because there weren't any computers in 97, and everyday I borrowed the typewriter. Everybody was mad at me, because the typewriter was always with me, and I was really happy, that I write letters with a typewriter. [...]

The fact that I was very lonely, my collegues fit in much easily, they went partying, had boyfriends, I was totally different in this respect. I went to prayer community, I went to masses, probably life seemed so hard, that religion and writing seemed like an important handrail. It is also interesting, that many of them, had helpers, either had a brother here, or relatives, or aunts, especially those from Pusztina, or they had very wealthy supporters.
} 
mindeközben úgy, hogy legalább úgy szerettek engem, mint én öket. Egy szó nem volt arról, hogy én egy rászoruló valaki vagyok, akinek segiteni kellett, ellenkezöleg mintha én kellettem volna nekik. Fantasztikus volt."

Talking to and with them made it clear that instead of studying philosophy - in which she was interested in the topics of the cause and origin of life, the God related questions - which were still in a central position - she should turn her attention to theology instead. Being in the third year of Teacher Treaining College and first year of Theology was only the first time when she was studying parallely at two universities. The MCSMSZ was already very active, but being situated in Moldova there were cases when they could not attend the events organized in Hungary so she was asked by the leaders of MCSMSZ to represent the organization.

\begin{abstract}
„Ez azt jelentette gyakorlatban, hogy el kellett utazni Munkácsra, Lendvára, Bécsbe és mindenféle ifjúsági szervezetek találkozóján, ahol a Magyar Köztársaság Miniszterelnöke is megjelent, a Sport és Ifjúság Minisztérium, az Oktatás és Kulturális Minisztérium képviselői is megjelentek, elöttük kellett megszólalni, velük kellett négyszemközt is beszélgetni, olykor személyes üzenetet kellett átadni. Borzasztó szégyenérzet volt ezeket véghezvinni. ",161
\end{abstract}

The first time sitting at a table with the prime minister of Hungary it was obvious to her what she had to do: she needed to study political sciences. The following year was also one of double study, studying theology and political sciences. The first degree was funded by the Hungarian state, the other were self-financed, and doing double majors, meant that working was possible only during nights or at week-ends, or working during summer in order to accumulate the amount of the scholarship.

\begin{abstract}
„Aztán felfedeztem magamnak a Domokos Pál Péter Alapitványt, ami Csíkszeredában van és Borbáth Erzsébet a titkára, irtam az alapítványhoz egy kérvényt, hogy szégyellem magam, hogy sokadik diplomám, de hogyha lehetöség van rá támogassák a tandíjat és akkor a teológia utolsó évét és a néprajz első évét már támogatták. "162
\end{abstract}

\footnotetext{
${ }^{160}$ In the meantime I met Pál Péter Domokos, his daughters especially, Mária and Erzsébet Domokos, and I told them everything what happened to me, I visited them regularly, they were teaching me, we were reading after each lunch from the works of János Arany. It was very interesting. They were teaching me to speak loudly, to articulate, doing this so that they loved me just as much I loved them. There was not a word about me being a needy person, who had to be helped, contrary like they needed me. It was fantastic.

${ }^{161}$ This meant in practice, that I had to travel to Munkács, Lendvár, Wien, and on every meeting of youth organizations where the prime minister of Hungary appeared, the Minister of sports and youth, the representative of the Education and Culture ministry also appeared, and in front of them had to speak, had to speak with them in private too, sometimes to transmit personal messages. It was a terrible shame to do these.

${ }^{162}$ Then I discovered to my self the Domokos Pál Péter Foundation, which is in Csíkszereda and Borbáth Erzsébet is the secretary. I wrote an application to the foundation, that I'm ashamed that this is my
} 
Ethnography, although not as a definite goal, appeared in Csíkszereda already, when she started to see with critical eyes the culture she is originating from. At theology the problem was the opposite of the teacher training college, namely that while the last one was very practical, theology was too theoretical.

„Szerintem, egy kicsit az lehetett, hogy a népi vallásosság iránt kezdtem el érdeklödni, teológus hallgatóként, de ehhez szerintem hozzátartozik egy tágabb környezet is, az, hogy tényleg reneszánszát élte a csángóvilág, különösen Budapesten, állandóan különbözö elöadások voltak a csángókról. És akkor az ember ilyeneken részt vesz, meghallgatja, hogy milyen a csángók vallásossága, meghallgatja Halász Péter, Tánczos Vilmos elöadásait, arról, hogy, hogyan imádkoznak a csángók, ezek nekem mind újdonság érzetü dolgok voltak, és akkor szerintem csak pont úgy alakult, hogy engem ez érdekel., ${ }^{163}$

When asked why is she interested in the topic of her ethnography dissertation giving one definite answer seemed to be the most difficult, she underlined the importance of responsibility, scientific interest, ambition, and all these together.

„Nem tudom, hogy miért, de semmi esetre sem azért, hogy én itt Budapesten kiváljak, mert erre nem használható ez föl, meg hát akkor még mindig nincs válasz arra, hogy miért pont én, miért nem a többiek, tehát ez egyáltalán nem arról szól, hogy valaki valahonnan jön és akkor abból a világból, itt teremt egy jó karriert itt, szó nincs róla. Eddig csak hátrányom származott abból, hogy ott születtem ahol, ezen kivül, vagy ettöl eltekintve, olyan szépséges és tragikus, de a szép az tragikus, olyan szépséges kultúrával nevelkedtem fel, amit nem cserélnék fel egy királyi gyermek életével sem, a maga nehézségeivel együtt. Meg az is hozzátartózik, hogy egy csomó hiányérzetem volt abban, ahogyan látnak minket, ahogyan felmutatnak minket. "164

umpteenth degree, but if it is possible to support the tuition fee, and then the last year of theology and first year of ethnography was supported by them.

${ }^{163}$ I think a little could be, that as a student of theology I started to be interested in folk religiousness, but I think this is part of a wider environment, namely that Csángó world lived its renaissance particularly in Budapest, there were different lectures about Csángós. And then one attends these, listens about how is the religiousness of Csángós, listens the lectures of Péter Halász, Vilmos Táncoz about how Csángós pray, these were all new things to me, and then things just happened that I am interested in this.

${ }^{164}$ I don't know why, but in no case for stand out here in Budapest, because this can't be used for this, and there is still no answer, why exactly me, why not the others, so this absolutely not about one coming from somewhere and out of that world, creates a career here, no way. So far I had only disadvantages because I was born there, beside this, or apart from that, it is such a beautiful and tragic, but beautiful is tragic, such beautiful culture in which I grew up, that I would not change this life for that of a prince, despite all it's difficulties. It also includes, that I had the feeling that something is missing in how we are seen and presented. 
The fourth presentation (younger than 35 former leader living in Moldova) could start similarly as it concerns education as did the previous one, yet as the young teacher - who graduated two universities one in Budapest and one in Bákó - chose to return to Moldova, the events took a different turn. She was the president for several years of the MCSMSZ, a thing that defines how things are seen and interpreted on local and on Moldova-Hungary level as well.

After graduating the 12th grade in Bákó in Romanian school with a mathematic profile, she applied to the NEI. She felt that while they were there in Budapest, Csángó students were without guidance and assistance. The goal of learning sociology or mathematics was thrown away by those who should've helped, saying that it will be very difficult. Later she realized that it would've been possible. At the influence of others after finishing the preparatory year started her education at the ELTE, in philology, studying at Romanian-Hungarian profile, from which she finished the Romanian profile, she could not pass one grammar exam in Hungarian, and she once again felt, that no one helped her, no one helped them in need.

„Nem tudtam, és annyi ember nyüzsgött körülöttünk, csángófelelös, de senki sem segített nekünk, egyedül nem boldogultam, pedig már az elejétöl jobban beszéltem a nyelvet, és ha valaki jobban beszéli a nyelvet, akkor a nyelvtan is intuitiv szinten benne van, de nem tudtam megírni az átmenöt, amit a vietnámiak és minden féle náció megtudta. "165

She tried out several jobs in Hungary as an intellectual, or in bureaucracy or as a physical worker but felt that none of them were serious enough to make her stay in Budapest or any other city. She remembers being always certain that she has to and that she will return to Moldova. After finishing university in 1998, for almost a year she worked in a Pub, in the village which was not the best decision but it was a necessity, then for 3 months she worked in a translator office, where Romanian citizens applied for German and Austrian visas in Hungary.

A meeting with Mária Petrás, Ilona Nyisztor and Anna Szőcs was important in how her life turned. Asking her to return to Moldova and work at the MCSMSZ was decisive. The goal was to bring back young qualified Csángós who could help in the work of the organization.

\footnotetext{
165 I could not, and so many people swarmed around us, Csángó responsible, but nobody helped us, I couldn't manage it alone, although I've spoken the language better from the beginning, and if someone speaks the language better, then the grammar comes intuitively to them, but I could not write a passing grade, what Vietnamese and other nations could.
} 
„Még 2000-2004-be is a szövetség, amelyik sokkal nagyobb volt, mint induláskor, jogi szempontból ugyanazzal a statútummal müködött, mint amelyikkel kezdte, de maga a statútum már rég nem takarta a valóságot. A valódi struktúrát, hát persze, hogy változott, próbáltuk hivatalosan is változtatni. A statútumba az volt, hogy a mandátumok rövidek, 1 maximum 2 évesek, voltak. "166

In that period, the legal backgrounds of the organization were changed, were actualized to the parameters at that time. After being the president of the MCSMSZ for three years she left the organization because in the meantime she started her second degree in mathematics. Other options than MCSMSZ were a necessity to keep in mind because the situation was somehow unclear as she remembers.

„Nem birta ki az ember többet, hogy... ilyen szempontból nem volt egy stabil dolog, amikor én elnök lettem akkor volt egy olyan módositás a statútumba, hogy legyen a mandátum három éves, hogy legyen folytonosság, a dolgoknak, a projekteknek, hogy lássék valami, és akkor én végig vittem a mandátumomat, na hát evvel dicsekedem. Addig egy elnök sem tudta végig vinni a mandátumát, vagy lemondott, vagy lemondatták, vagy valami, én végig vittem a három éves mandátumomat, utána még egy félévet maradtam a szövetségnél. "167

As soon as she graduated, started to work as a mathematics teacher in a Csángó village. She is not using her ELTE degree; yet thinks that probably she could teach Romanian language and grammar, and accepting her Hungarian degree could be done.

\footnotetext{
${ }^{166}$ In 2000-2004 the organization which was much bigger than at the beginning still was functioning in legal aspects with the same statute as in the beginning, but the statute itself was not accurate. The real structure, obviously has changed, we tried to change it officially too. In the statute it was that mandates are short, of 1 maximum 2 years.

${ }^{167}$ No one could resist more ... in this matter wasn't a stable thing, when I became president it was such a change in the statute, that a mandate is of three years, to give continuity to things, to projects, so change could be seen. Then I took to the end my mandate that is something I can brag with. Until then no president could take to the end the mandate, either resigned, either were made to resign, or something else, I brought the three year mandate to the end, after it stayed for a half year at the organization.
} 


\title{
5.3. The historian
}

The following representative (younger than 35 employee living in Hungary) is also the member of the younger generation, who also opted to remain in Hungary after graduation and to serve the Csángó community - according to the roles expected from elites and by other elites as well - from here. Roles in this case are mainly concerned with scientific representation of the Csángó past, history.

The 1989 regime change brought change on a personal level as well. In the lives of young Csángós this change was best seen through their education in Csíkszereda.

\begin{abstract}
„Elsö hallásra megdöbbentő volt a dolog, annál is inkább, mert nem igazán volt nekünk képünk arról, hogy Romániában élnek még máshol, nagy tömbben magyarok, ahol netán a magyar nyelv egy iskola szinten is müködö nyelv és hát igen elgondolkodtató, hogy milyen lesz magyarul tanulni. Még egyáltalán a magyar nyelvet, mint olyant nem ismertem, csak a csángó változatát, úgyhogy ezen a megdöbbenésen túllépve 90 öszén, szeptemberben kerültem ki elöször Csíkszeredába. "168
\end{abstract}

Expected language difficulties proved to be overestimated, since in about only three months he managed to catch up the Hungarian language which at the beginning seemed much more different from the more archaic Csángó dialect spoken in their village. From 1990 he continued his education in the $6^{\text {th }}$ grade, where a very important role was played by the school director and Hungarian teacher, Borbáth Erzsébet, about whom he remembers that held together and coordinated Csángó students not only mentally, psychologically but materially as well. At the beginning the material background of their education was very uncertain, accumulating bills and not having the funds for the tuition of students the lack of a foundation that could organize, coordinate and finance all this was very obvious.

\footnotetext{
„Rohantak a Lajos atyához - György Deák Lajos atya volt - hogy ki kéne fizetni ezt meg azt. Lajos atya pedig kijött Magyarországra összekoldulta a pénzt, hazajött és kifizette. S akkor ez igy ment azt hiszem 1-2 évig. Utána Erzsike néni kezébe vette a dolgokat, és a Domokos Pál Péter Alapítványon keresztül szerezték, szponzorokon keresztül világszerte, USA-tól Ausztráliáig az anyagi hátteret. Volt olyan év, amikor sikerült kiharcolnia, a
}

\footnotetext{
${ }^{168}$ At first it was shocking to hear, especially that we did nothave any vision about Hungarians living, in large array, anywhere in Romania, where perhaps Hungarian language is a language that works at school level as well, and it was worthy to think over, how it will be like to learn in Hungarian. I didn't know the Hungarian language as such yet, only the Csángó version, so steping beyond this shock at the fall of 1990, in September was the first time I got out to Miercurea Ciuc.
} 
magyar minisztériumtól, hogy minden csángó gyerek ösztöndijként kapja meg a költségeket,

a tanulásra, tanittatásra és bentlakásra. "169

An important step in their education was applying to the $9^{\text {th }}$ class, which was based on an exam. It can be seen today as well, and it was true in 93 as well, that Csángós mostly applied for human studies and professional schools.

„A mi korosztályunkból, köszönhetöen annak, hogy Erzsike néni akkor volt a legaktívabb, nagyon sokan mentünk középiskolába. Úgy emlékszem, hogy harmincas létszámból kb. 1819-en biztos elmentünk középiskolába, ami nem tünik olyan soknak elsö hallásra, de lévén hogy csángó osztály voltunk, mégis sok. A késöbbiek során amint kiderült, ez nagyon nagy létszám volt. ",170

Continued his studies in Csíkszereda, at a Catholic Seminar high school, where having very strict professors and being a clerical school, provided not only professional education but by severe discipline a particular life course as well. Those who had the baccalaureate in that school were likely to continue their studies.

In 1995 he participated on a trip to Hungary where they had some history classes, being one year before graduation he decided that he will continue his studies in Hungary where he would learn History. In 97, after the baccalaureate he decided to come to study in Budapest, at the International Preparatory then Hungarian Language Institute (NEI). Selection was with serious matriculation, because many Csángós were in high schools in different schools in Transylvania and in Moldova as well. Not only those opted to study in Hungary who were learning in Csíkszereda but also children who graduated in Moldova.

Having this kind of competition for the chance to continue in Hungarian higher education system was very beneficial for the Csángó matter and for young Csángós. They were more that thirty applying to ten places and although this wasn't such a big competition, because compared to years when there were eight, ten people to one place felt that it is still an oversubscription that allows filtering the most talented ones it was

\footnotetext{
${ }^{169}$ They were running to father Lajos - father Lajos György Deák was the one who - that this and that should be paied. And father Lajos came to Hungary and begged the money together, returned home and paied. And this was like that for 1 or 2 years. Then aunt Erszike took over things and through the Pál Péter Domokos Foundation they found material background, through sponsors from all over the world, from USA to Australia. There were years when she managed to fight out from the Hungarian ministry, that all csángó children to receive the expences in the form of scholarships for teaching, tuition and housing.

${ }^{170}$ From our generation, due to the fact that back then Auntie Erzsike was very active, many went to secondary school. I remember that, from thirty about 18-19 of us went to secondary school, which doesn't seem so much, but given that we were a Csángó class it was much. As later was tunred out this was a very big number.
} 
still a strong competition. 5-6 years later interest toward this opportunity decreased significantly. Later for the 10 places if 5-6 people applied was still good, at the end of the 2000 years $2-3$ people applied only.

„A túljelentkezés nagyon jó volt, mert volt akiböl választani, volt lehetöség megszürni azokat, akik mondjuk nem tanulni akarnak kijönni, hanem csak Budapestet látni, vagy csak egyetemet akar végezni, és nincs más lehetösége mert Bukarest nem ad ösztöndíjat, Budapest viszont ad és bár identitásában mélyen románnak érzi magát, mégiscsak kijön és elvégez egy egyetemet. Sajnálatos módon voltak ilyenek is, többen mint gondoltuk volna, utólag mint kiderült és ez minket irritált, mert úgy éreztük rászállnak erre az ügyre a csángó ügyre és kihasználják. ",171

In the meantime, in 1993, the entire family moved to Transylvania, along with two other families, later to be followed by others. The idea of moving Csángós to Transylvania belonged to the priest of Csíksomlyó, who thought, that the only way to keep the Hungarian identity and consciousness of Csángós, and to consequently do that for several generations, is to relocate them into a Hungarian majority. Given the opportunity to leave Moldova with the purpose of studying might work, but their return is uncertain, and Hungarian education in Moldova was very unreal in that time.

„,Gergely István úgy gondolta, hogy a kiköltöztetés a jobbik megoldás, mert aki kikerül Erdélybe az minden bizonnyal megmarad magyarnak és gyerekei, unokái szintén, tehát nem olvad be. Aki kint marad az elöbb utóbb, ha nem ö akkor a gyereke, ha nem a gyereke az unokája, de előbb utóbb sajnos a körülmények miatt asszimilálódni fog."172

Not having political support in this aspect the initiative affected only 6-7 families. The first three families were from the same village, later other families joined them in a homogeneous Hungarian village surrounded by Romanian localities in the Transylvanian Plain. At only 14 it was the second place they had to fit in.

„Ezek mind fontos állomások voltak az identitás formálásában. Szeredában rádöbbentem arra, hogy én magyar vagyok és hogy létezik Magyarország mint olyan, ... lehet hogy... nem azt mondom hogy 3-4 év múlva az iskolában nem derül ez ki számomra csak ugye akkor még 11 éves voltam, ez az iskolában még annyira tabu volt 89-ig, hogy nagyon

\footnotetext{
${ }^{171}$ Oversubscription was very good, because there were people to choose from, it was possible to filter those who are coming to Budapest not to learn, but to see the city, or to finish a university, and there was no other possibility, because Bucuresşti doesn't give any scholarships, but Budapest does, and although in his/her identity is deeply Romanian still comes out and finishes a university. Unfortunatelly there were like this too, more than we have thought of, as later was obvious and this irritated us, because we felt that are invading this matter, the Csángó matter and are taking advantage of it.

${ }^{172}$ István Gergely thought, that moving out is the better solution, because who manages to move in Transylvania presumably will remain Hungarian and his/her children, grandchildren as well, so that they won't be assimilated. Those who remain outside sooner or later, if not him then his children, if not the children than the grandchildren, but sooner or later unfortunately due to the circumstances will assimilate.
} 
meglepö volt. Magyarok között élve is, faluban is mindenhol magyarul érvényesülve egy kicsit az ember úgy identitásában jobban tudott erösödni, formálódni. ",73

The move of the family to Transylvania and education in Csíkszereda had a definite effect on his identity, although not only the parents but all of them, all brothers learned to speak first of all in Hungarian. He remembers that by the time he went to school he couldn't speak Romanian at all. It was not a conscious decision driven by the Hungarian consciousness of the parents, but it was something due to the medium that was natural to them. The formation of identity of a grownup - which is different than in the case of a child, that could easily fit in - is presented through his mother, who in Moldova knew that she is Csángó, and in Transylvania she was strengthened in her knowledge that is Hungarian and being such is not a bad thing, is not something to be ashamed of, it was a strong forming factor.

From the $9^{\text {th }}$ grade he planned to continue his studies in Hungary, after receiving books in Hungarian. Hungary appeared as a place of freedom and he recalls that Budapest was to him as it was the Free Europe in the previous regime for many citizens of communist regimes. To step out and experience a different intellectual medium, the strengthened identity, the intellectual freedom of people which is not limited, constrained by anyone telling what to do and how to do it.

In 1997 he started to study in NEI. As it concerns the professional aspects, teaching, education, the education system was what and how he expected it to be, but the life style in Budapest, and the town as such in the least way meet the expectations.

„Egy csángó faluból indult embernek ... Ady Endrének nagyon igaza van, , Valaki az Értöl indul el, s befuthat a szent, nagy Óceánba"... Nem hiszem, hogy a szent, nagy Óceánba befutottam, de körülbelül ezt az utat éltem meg, ezt a szimbolikus utat, hogy itt Budapesten egyetemre kerülni és Budapesten élni egy csángó faluból, az tényleg nagyon nehéz volt."174

Fitting in to the lifestyle, culture and communities encountered in Budapest was much harder than doing the same in Transylvania. He remembers life being a rush, life with which he just couldn't keep up, but after around half a year stopped noticing that.

\footnotetext{
173 These were all important points in the forming of identity. In Csíkszereda I realized that, I am a Hungarian and there is such a thing as Hungary ... it is possible ... i don't say that in 3-4 years this would not been clear for me in school, only that I was 11 then, and prior to 89 this was such a taboo in school that it was very schoocking for me. Living among Hungarians, prevailing in Hungarian in the village and everywhere one can strenghten and form in one's identity.

${ }^{174}$ For someone who departed from a csángó village ... Endre Ady was very right „Someone departs from the spring and might run into the great, saint Ocean", ... I don't think that I have runed into the great,m saint Ocean, but more or less this is the path that I have lived, this symbolic path, to enter from a csángó village to a university here in Budapest and to live in Budapest, it was indeed very hard.
} 
In 2003 he graduated in History - dropped the Hungarian profile - after one year of searching he could not find a job as a teacher, so started to work as a librarian at the Semmelweis University. After getting the degree was an important choice as to whether he should stay in Hungary or return to Romania. He remembers the strong decision of not returning home that lived in him when he came to study in Hungary, also how after two years he felt that will return home because on one hand there is a need for him there, on the other hand felt as a moral duty to return to the csángós who remained there to teach them all he had learned in Hungary.

After marrying a girl from Hungary, returning to Romania seemed difficult, so they decided to remain, but keeping the Csángó matter in the forefront of life is a high priority although he says that doing anything for those Csángós who are in Moldova is difficult, and from Budapest he can't do too much. 


\title{
5.4. The man of a formal organization:
}

Elites and intellectuals should be present in formal organizations as well. The following portrait (younger than 35 current leader living in Moldova) is of another young Csángó with several degrees earned in Hungary who also opted to return to Moldova. He is currently working at the MCSMSZ and its subsidiary association.

He is one of the young Csángós who walked the road of education leading from Moldova through Transylvania and Hungary back to Moldova. After having three degrees - school-teacher, informatics and human-management - he followed his initial plans of returning to Moldova. He was asked by the leaders at that time of the MCSMSZ, if he would accept to work as a project manager at the organization. After working only one week at the organization the leaders resigned and he was named as temporary president later to be elected as formal president, fulfilling that role for three years. As he recalls the situation of the organization was pretty hard, having economic difficulties with unpaid bills, occasionally no telephone and electricity supplies and only about 50 members, but not even those were all active members. There was something positive though, namely that initiation and support of the Hungarian teaching was very active and present:

\begin{abstract}
„, ami mégis pozitív volt az, az hogy el volt inditva a folyamat, hogy az iskolába bevezetni a magyar nyelv oktatását. Akkor születtek meg ezek a rendeletek, amelyek ezt lehetővé teszik. Akkor volt kormányom az RMDSZ a szociáldemokrata párttal és akkor, nem pont utána lett a választás és akkor jött a szociáldemokrata kormány és akkor is már lehetett intézni dolgokat. Voltak kérvények, voltak kapcsolatok iskolákkal. "175
\end{abstract}

At that time they had not succeeded to introduce the Hungarian language in the regular school schedules, so at the motivation of Attila Hegyeli they put the grounds of extracurricular teaching, starting in the fall of 2000 in Klézse, and in the January of 2001 in Pusztina. Another success of the organization and its leaders of that time is that they not only brought the economic aspects in balance but managed to buy their first office. A following step was to ensure not only the economic aspects but the human capital as well, namely to reinforce the organization having several and more active members. At the end of 2001 about 800 people asked to be subscribed as members of

\footnotetext{
${ }^{175}$ What was still positive is that the process to introduce the teaching of Hungarian language in schools was started. Those regulations that made this possible were born then. The RMDSZ was in the government with the Social Democratic Party and then, not quite after that with the elections came the Social Democratic government and organizing things was possible. There were applications, there were contacts with schools.
} 
the MCSMSZ. He is aware that all those 800 people were not planning to be key figures of the organization, since around that time it was possible to ask for a Magyar Igazolvány (Hungarian certificate) from the Hungarian State. There was a precondition in order to receive the certificate: the applicant had to be the member of a Hungarianrelated association organization, or a Hungarian political party, or a historical Hungarian church. In Moldova the only opportunity as such was the MCSMSZ. The number increase of members is due to this coincidence as well. Another success was that they managed to include more and more localities where Hungarian teaching was initiated. So far it seems as a success story but as many other - minority and not only organizations they had their difficulties as well.

„2001-ben perelt be a tanfelügyelöség azért mert mi iskolán kivüli oktatást inditottunk. És három szinten ezt meg is nyertük a tanfelügyelöséggel szembe, tehát alapfokon, bíróságon s tábla bíróságon. Egyszerüen nevetséges volt, mert ugyan akkor megszülettek az Európai Tanács számunkra vonatkozó ajánlatai is. , ${ }^{176}$

Later Hungarian classes were introduced in the regular school schedule - as optional classes - but the teachers who are holding these classes usually don't have a full professorship, so they are also involved in the extra scholar activities and they are paid proportionally by the school inspectorates and the MCSMSZ.

The operation of the organization depends highly on economic backgrounds, including a new location/village in the Hungarian teaching palette - renting a building were classes can be held, paying a teacher and provision of school supplies - involved substantial extra expanses.

The current goal of the organization is on one hand to build up subsidiaries in as many villages as possible and second that funding and organizations to be realized locally. In Pusztina there is the A Pusztinai Házért Egyesület (Association for the house from Pusztina) nowadays the Hungarian teaching is entirely done by this association. In 2003 they purchased the land and in 2005 built up the house, the location is suitable not only for the teaching but accommodation of tourists and also for organizing events for which previous, rented locations proved to be too small.

Another argument to have this kind of locations was that renting the local community center was usually very circumstantial for the MCSMSZ, often depending

\footnotetext{
${ }^{176}$ In 2001 the school inspectorate sued us for initiating extra scholar education. On three levels we won against the inspectorate, so a basic level, judiciary and judicial board. It was simply ridiculous, because just then the recommendations of the European Council concerning us were just born.
} 
on the local political or clerical leaders, who were not always supporting the activities organized by the organization.

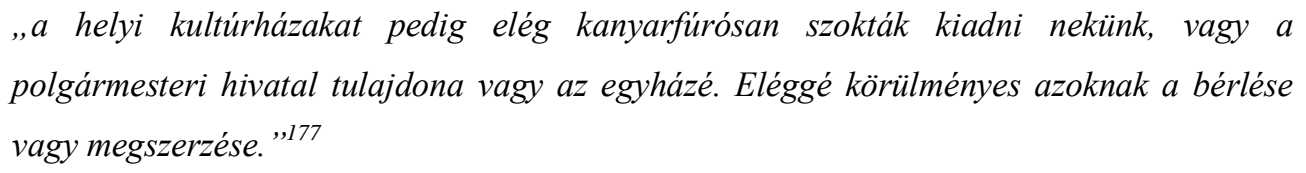

In the fall of 2003 he resigned as the president of the MCSMSZ, and in order to have a feed-back to his education and degrees, to try himself in his profession worked at an advertising company for 2 years. In the meantime the Godfather program was initiated as a background institution ensuring the resources.

„,Közbe itt kitalálták a keresztapa programot, nyilván az volt az én idömbe is, hogy túl kevés volt a forrás, hogy mindig csak célzott támogatások voltak. Nehéz volt müködési költséget szerezni, nehéz volt fizetéseket biztositani, nagyon körülményes volt." ${ }^{\text {,178 }}$

Currently he is in key positions in two organizations concerning the Csángó matter.

\footnotetext{
177 The local community houses were rented to them in a quite "convoluted" way, they belonged either to the mayors office either the church. It is quite circumstantial to rent or to acquire them.

${ }^{178}$ In the meantime they figured out the Godfather program. Obviously what it was in my time as well, that it were few funds, there were only targeted funding, It was difficult to obtain operating costs, it was difficult to provide salaries, so it was very circumstantial.
} 


\subsection{The priest}

For many Csángós the number one elite is the priest, two of them shall be presented in this subchapter. First (younger than 35 church representative living in Hungary) graduated in Theology and currently works in Hungary. He is enrolled in PhD studies in Italy. When speaking with someone who has a high education, especially higher than the average of the community it is always interesting to follow up the road leading through different schools and locations.

Like many other Csángós, he started his education in his home village where he learned all subjects in Romanian. He recalls that in the fifth year one of his school mates brought a Hungarian book to school and then he realized that it was the language they use at home, the language they spoke with their parents and among brothers is a language that has a written form as well. They only spoke it, could not write or read in Hungarian. Seeing that book, was his first meeting with the literary Hungarian. After the regime change with the Hungarian TV programs he had more regular contacts with the language. One year later when Lajos György Deák went to their village and spoke about the opportunity to learn in Csíkszereda in Hungarian, it seemed a good choice in several aspects, not only as it concerns the language of teaching, but something else too, it was a possibility to escape:

\section{„Fölmerült ez a lehetöség, bennem mindenképp ott volt a menekülési vágy, vagy menési vágy, hogy abból a környezetböl kiszakadni. Nem mintha nem éreztem volna magam jól otthon, csak egyszerüen úgy bennem volt az, hogy valahova menni, és valamit csinálni. ",179}

Having an older brother - in the $8^{\text {th }}$ grade - who was leaving for Csíkszereda his parents wouldn't let him go too, after some long fights, as he remembers, they went together. He started the $7^{\text {th }}$ with the studying of the ABC. Having a Hungarian teacher as in the life of many others from that generation the school principal of that time and their Hungarian teacher, Borbáth Erzsébet is a key figure - who was able to explain the literature and the grammar in a way that was understandable for kids with their educational background, they managed to catch up, and to actually understand the Romanian grammar as well.

While he was studying in Csíkszereda several trips were organized to Hungary and he stresses out that by concentrating not only on education but on providing

\footnotetext{
179 The option came up, anyway it was my desire to escape, the desire of going, to tear from that environment. Not like I was not feeling good at home, just simply it was in me to go somewhere, to do something.
} 
different experiences for the young Csángó children, Lajos György Deák and Erzsébet Borbáth managed and succeeded in ensuring them with a more open minded perception.

He graduated in a Catholic school in Csíkszereda, and recalls that learning as a motivation appeared only later, when he already was a theology student. He assets that he has very positive memories about Csíkszereda.

„Visszaadták az elvárásaimat, azzal, hogy az ember kiszakadjon egy ingerszegény környezetböl mind tanulmányi, mind más szempontból. Az ember mást akart látni és vágyott valami többre, mint ami volt, legalábbis ez volt bennem. ",80

From 1997 he studied at theological college in Veszprém, he was the first who earned a university degree in the Veszprém College, others usually gained the college degree. After graduation he worked as a chaplain in Siófok which had a main role in his postgraduate education. He remembers that the parish from there once brought an Italian letter to him to read it, a letter informing him that a scholarship was offered by the University of Venice in law studies. Between 2004 - 2007, he studied cannon law in Venice, graduating in his MA in 2007. Since his graduation he is a vicar and in the meantime started doctoral studies at the Santa Cruce University in Rome.

As for many people with high education for him as well, the education of the young generation is an important, almost vital question. Considers that Csángó kids were never thought to learn, there was no motivation in this regard, neither from parents nor from teachers. Including kids in the - mostly agricultural - works of the household was often more important than learning.

„Nálunk hiányoztak az alapok odahaza, az, hogy a gyerek olvasson, tanuljon. Nem tanitottak meg minket tanulni. A mi vidékünkön a munka volt a legfontosabb, a kinti munka, a szezonális munka, kapálás, kaszálás és összességében minden más fontosabb volt." ${ }^{181}$

There is always the question why aren't the Csángós who already earned a degree, and have a profession returning to Moldova? Speaking about these questions with other peers he sees that many of them are more likely to remain because they get answers to their initial expectations and they don't really desire to go back. As such Moldova turns into a place where they go occasionally, a quite milieu good for relaxing.

\footnotetext{
${ }^{180}$ Returned my expectations, that a person should tear out from an environment that is poor in stimulus in educational and other aspects as well. One wanted to see something else, wished something more than it what it was, at least this was with me.

${ }^{181}$ We missed the basics back home, things like a child should read, learn. They didn't teach us how to learn. In our region work was the most important, the work outside, the seasonal work, hoeing, mowing and in general everything else was more important.
} 
The second priest (36-50 years old church representative living in Hungary) is the same age as the first one, who graduated in Moldova and was delegated for a limited time by the episcopate of Iaşi to Budapest where he works and continues his studies.

He started his studies in the home village, and later learned in Temesvár, in highschool seminar, then went to theology. For two years he studied Philosophy in Gyulafehérvár, ane then returned to Iaşi where he graduated the seminar. He considers important that while there were 13 people of 7 nations in the class in Temesvár there were no problems, no fights, no debates; it was a second family for him. The problem of ethnicity become important in Gyulafehérvár: there he met the problem of how important is being Hungarian or Romanian for someones. After graduation he worked as chaplain in a village, in Moldova. He sees it as one of the most important problems encountered in Moldova and Romania as such migration and its consequences on the education of children who had left home.

"Az volt a legnagyobb gond, hogy az ifjú szülök, több mind negyede annak a falunak, mentek Olaszországba, Spanyolországba dolgozni, ott hagyták a gyerekeket és nagymama, vagy mit tudom én ki vigyázott rá. Arra is lehetett figyelni, hogy mennek tönkre ezek a gyerekek, mert sem a nagymama, sem a nagynéni nem figyelnek úgy, mint a szülök. "182

After working there for two years - mostly with children and youth - in the $11^{\text {th }}$ of September 2008 he came to Hungary by the order of the bishop of Iaşi. Besides working as a priest another task was given to the two delegated priests, they had to enroll to learning at a Hungarian university, studying canon law. Another important task was to search up those members of the community who are from Romania, from the Csángó villages and are working in Hungary and to hold masses for them on Sundays. Their main role was to work for the community of those Catholics who are from Romania and are working in Hungary.

Since they are here, Romanian masses were held in two locations, first in Zugló, then in the church in Batthyányi tér. Romanian masses are held every Sunday, and there are always at least 70-80 people, sometimes more but never less than that. When asked about his work in Budapest he said that is not the same as in Moldova. After the masses they are holding some gatherings for the believers, where they can speak about their problems, concerns, whether they have a job or not, etc.

182 The major problem was, most of one quarter of the young parents of that village went for work to Italy, to Spain, and they left their children behind, to be taken care by grandmothers, or I don't know who. It can be noticed that these children are destroyed, because neither the grandmother, nor the aunt pays so much attention than the parents. 
When the two priests were selected an important factor was their Hungarian knowledge. Although both consider Romanian their mother tongue, they both spoke the Hungarian at a level that was improvable. The Csángó dialect can constitute a good base for the Hungarian language. He underlines that in order for one to speak the correct Hungarian one has to learn that from the parents and to use it on daily basis. He admits that the Csángó dialect is a form of the Hungarian language but knowing it is not enough to speak correct Hungarian.

\begin{abstract}
„Azért mondtam sokszor, hogy talán igen, a csángó nyelv egy régi magyar nyelv, ami nem fejlödött, és sok szót vett a román nyelvböl, csak a magyar kiejtéssel, ragozással. Azért is van sokszor az ember, akik ide jönnek Magyarországra, kik nem értenek magyarul, talán ezt az egyszerü, konyha beszédet, ezzel valahogy megoldják. Szakszavakat, vagy tanulni magyarul, vagy írni magyarul, az nehéz.,"183
\end{abstract}

Just like in many other Csángó families the first language is not necessarily the same for all family members. There are families where parents speak among themselves in the Csángó dialect, with the children they use Romanian, while the children among themselves - especially if the learned in Transylvania or Hungary, or were enrolled in long term transnational migration - might use Hungarian or even a third language.

„A testvérek el voltunk osztva, volt, aki beszélt csángóul, én például, még van, egy bátyám s egy húgom mi nem beszélünk egyáltalán csángó nyelven. A csángó nyelvet tanultam, miután tanultam helyesen magyarul Temesváron. "184

When he told to his parents that he plans to become a priest, was not supported by his father. In the first two years was funded by his mother, later he had to finance his own education. Considers important to realize that one could learn and get a degree even he/she has to finance their own education. In his view Csángós are often waiting for help from outside and outsiders often think that Csángós should he helped with presents and funds. He thinks that education is the most important, and children and parents as well should realize that learning is the only possibility that could bring long term solution and guest working is only temporary well being.

\footnotetext{
${ }^{183}$ This is why, I often say, that maybe yes, csángó language is an old Hungarian language which have not evolved, and took many words from the Romanian language, but with Hungarian pronunciation, inflection. This is why often, when a man comes here to Hungary, who can't understand Hungarian, maybe with this simple kitchen language, with this they solve it somehow. Specialized words, or to learn in Hungaria, to write in Hungarain, that's difficult.

${ }^{184} \mathrm{We}$, the brothers were divided, there were those who spoke in csángó, me for example and I have an older brother and a younger sister, we could not speak in csángó language at all. I learned Csángó language after I learned to speak correctly in Hungarian in Temesvár.
} 
„,Mi most folyik nálunk, Moldovában is, visszafordul ellenünk. 15,17 évesen már indulnak és dolgoznak Olaszországban, nem is fejezik be a gimnáziumot, érettségijük sincs, s mennek ki. Talán most jól keresnek, de utána meglátják, hogy nem ebben áll az élet, hanem majd onnan is fognak kérni egy papirt, hogy mi a végzettségük,"185

Knowing a profession but not having a certificate about it, is not enough anymore. Being a good professional in constructions, having foreign experiences and knowledge accumulated in other countries is an advantage, but he thinks that after a while education and having a degree is a must that not too many Csángós can fulfill so far. Even if not higher education, people should finish at least a professional school or a baccalaureate.

„Olaszországba is, Spanyolországba is voltam. Most mindenki lassan-lassan visszamegy, mert elég nehéz ott is, mint nálunk is. Az embernek, ha nincs egy végzettsége, akkor ez nem megy. Tölem a családból én vagyok egyedül ki többet tanult. Mindenkinek megvan a szakma iskolája, tanult valamit. Csak egy testvérem van, aki csak 8 osztályt végzett, nem azért mert nem engedték, azért mert nem akart. Ö most látja és bánja, de már túl késö.,"186

In order to serve the community and to have a successful life, first of all one has to learn. Unfortunately education did not have a high priority in Csángó families, things are now changing somehow, but there are still cases when an outsider, not a family member has to step in, and convince the parents that learning is good and worthy to invest in.

\begin{abstract}
„,Mikor még Romániába voltam támogattam négy gyereket, hogy tanuljanak. Emlékszem volt egy léány, akit a szülök nem akartak engedni tanulni. Beszéltem a szülökkel is, mondtam, hogy támogatom, segitek nekik, és most befejezte. Ez egy jó dolog, be tudta fejezni az egyetemet is, most masterre iratkozott be. Aztán látták a szülöks a testvérek is, hogy ennek van egy értelme. "187
\end{abstract}

\footnotetext{
${ }^{185}$ What is going on not at us, in Moldova too, it will turn back on us. 15, 17 years old, and they are leaving to work in Italy, they haven't even graduate high school, they don't even have baccalaureate and they are going abroad. Maybe they earning good now, but they will see later, that life is not more than this, because they will be asked for a paper, what is their education.

${ }^{186}$ I've been in Italy, and in Spain, and there too everybody slowly is going back, because just like at us there is difficult as well. If one, has no education, than this is not going. From my family I am the only one, who learned more. Everyone has a profession, learned some. I have only one brother with only 8 classes, not because it was not allowed, but because he did not wanted to. He is seeing and felling sorry, but is too late.

${ }^{187}$ When I was still in Romania I was supporting four children in their education. I remember, there was a girl, whose parents would not allow her to study. I spoke with the parents, I told them that I will support them, I will help them, and she graduated. This is a good thing, she was able to finish university, now she is applying for a Master degree. Later the parents and the brothers realized that it makes sense, and worth it
} 


\title{
5.6. The advocate
}

The following portrait (older than 51 former leader living in Hungary) is of the person who was most often named as representing the interests of Csángós. She lives in Hungary where she received a university degree, worked for the government as well and is involved in several events concerning the representation and presentation of Csángós and their culture in Hungary.

She learned in Romanian and when she was 14 went to Transylvania first to continue her studies later to work in an airplane factory. For two and a half year was learning in Brassó, then she moved to Sepsiszentgyörgy were the class was bilingual, about 32 Hungarians and 8 Romanians, she was one of those 8. Profession subjects were in Romanian for everyone, and some subject were only in Hungarian for the majority of the class. Sepsiszentgyörgy had a great importance in her life. Like many other Csángós, she also presents a life story in which the first encounter with the importance of ethnic identity wins validity when they move to Transylvania.

„Szentgyörgyön elkezdödött a nagy élet, mert ott találkoztam a nacionalizmussal elöször, mert ugye ott a magyarok gyülölték a románokat, a románok a magyarokat, s aztán minket mindenki gyülölt, a magyarok is és a románok is. "188

The conflicts among Széklers and Csángós are present in her life-story as well. Differentiated by Hungarians and Romanians as well, speaking a very specific dialect of the Hungarian and being Catholic are seen as factors that can be used by both Hungarians and Romanians in order to distinguish Csángós from themselves.

\begin{abstract}
„Mert sajnos azért Székelyföldön nem fogadtak bé minket, rendesen „hegyen-túliak” voltunk, bocskorosok, románok stb. Hiába mondtam nekik, hogy nem tünik fel nekik, hogy katolikus vagyok, nem tünik fel, hogy magyarul szólok hozzád? Nem! Hegyen túl születtél, bákói vagy, a buletinbe azt irja bákói. Szóval ennyit a székely testvérekröl, nem is tudtak ök szerintem semmit rólunk, meg is voltak egy kicsit döbbenve. "189
\end{abstract}

As she recalls she was active in Csángó matters on that period as well. Tried to convince other Csángós in accepting their language and use it against the negative attitude of Széklers.

\footnotetext{
${ }^{188}$ In Szentgyörgy the big life started, because there I first met nationalism, since there Hungarians hated Romanians, Romanians hated Hungarians, and everyone hated us Hungarians and Romanians as well.

${ }^{189}$ Because unfortunately in Széklerland we were not accepted, usually we were those from "beyond the mountains", with sandal (a sort of Romanian show), Romanians,etc. Vainly I was saying, that can't they notice, that I am Catholic, can't they notice that I address them in Hungarian? No! I was born beyond the mountains, you are from Bákó, in the ID it sais from Bákó. Só that much about the Székler brothers, they did not know to much about us I think, there were a bit shoked.
} 
"Hát voltak olyanok, akik meg sem szólaltak magyarul csak románul beszéltek. Azt mondták, nem akarnak senkinek alkalmat adni, hogy kiröhögjék." ${ }^{190}$

She was one of the first Csángós who migrated - in 1987 - to Hungary. She felt like a white raven, the borders were opened for migration only later, although she came legally she said that it was almost like coming on the green border. Leaving from Moldova to Transylvania one would encounter one sort of Hungarian culture, moving to Hungary one finds another sort of the same culture. She remembers being very lucky for meeting mostly intellectuals in Budapest, and from their part she felt no discrimination. She was accepted.

„Akkor volt ugye itt es a változás. Tüntettünk Erdélyért, bekerültem a FIDESZ-es körökbe is, együtt jártunk gyülésezni, nagyon klassz volt. Tényleg az a nagy-nagy lendület, a váltás, akkor más volt a szituáció, más volt az érzés. "191

Before the regime change she applied for Ethnography at the ELTE, but was not accepted, Pál Péter Domokos offered her to help in her studies but wanted to do on her own so not starting the university education, she started to work. The regime change brought increments on a personal lewel as well. Until 2000 she was never alone in her apartment, there were always staying two, three, four, five people. It is the time when she got connected with many Csángós. All those times and relations are being repaid now. Since those guests were only passing by in the sense that they were going for work to Italy, Germany, France, Spain, etc. now she is the one who is visiting them. Even today she keeps regular contact with many Csángós who live in Western Europe, many of them are "those with Audi 8".

In 1998 she started to work for the Hungarian government.

„,Tehát ez a nagy mozgalmista, meg csángó klubokat szerveztem azelött, tehát mindenki tudta, hogy én foglalkozom a csángó üggyel és igy bekerültem elöbb a Millénniumi Kormánybiztos Hivatalba, és ezután A Nemzeti Kulturális Örökség Minisztériumába, mert az Orbán kormány elkülönitett loo millió forintot a csángókra, „Csángókultúra és oktatás” úgy hivtuk, rendesen a költségbe fejezeti címként. "192

\footnotetext{
${ }^{190}$ There were some who didn't speak a word in Hungarian, only spoke in Romanian. They said, that they don't want to give anyone the opportunity to laugh about them.

${ }^{191}$ Then it was here the change. We demonstrated for Transylvania, I got into FIDESZ circles, we went to meetings together, it was very cool. Indeed that big-big élan, the change, it was a different situation, different feeling.

${ }^{192}$ So the big activist, before I organized csángó clubs, so everybody knew that I take care of the Csángó matter, so I got first to the Millenium government office, and then to the Ministry of National Cultural Heritage, because the Orbán government allocated the Csángós 100 million forints, in the cost appeared as a chapter title of "Csángó culture and education."
} 
Returning to her own education she says that her life goal was to have a higher education. Even as a child loved to read, yet all her reading experiences were related to the Romanian language, in Hungarian started to read when she was already 19. Reminiscing about a trip to her older sister living in Transylvania, she says that she was 13 when she realized that Hungarian is a written language.

\begin{abstract}
„, Kimentünk és Ojtuznál, ugye átmentünk a határon, és ott látom, hogy Lebény az első magyar falu, és ki van írva, hogy pâine és kenyér, és 13 éves koromban tudtam meg elöször, hogy a magyar nyelv, irott nyelv. És akkor jöttek a falvak szépen, még Brassóban is volt, több magyar felirat, úgy, hogy megmondom én öszintén, hogy meglepödtem, de csak annyira, hogy irott nyelv, ezt a nyelvet, amit beszélünk ez irott." $" 193$
\end{abstract}

Education, learning, getting a degree are important things in her life. Having the desire of learning and seeing the importance of education and knowing in the family,even if it was through autodidact ways - when worked for the government, by desire and by necessity enrolled into higher education.

\begin{abstract}
„,Gyerekkorunkban a puliszka mellett hallgattuk a bátyámnak az elöadását Senecáról, Kantról, stb. A mi családunk tényleg egy olvasott család volt egyrészt, másrészt pedig mind nagyon jó tanulók voltunk. Tehát a hétböl négyen biztosan végeztünk volna egyetemet és biztos legalább ketten ledoktoráltunk volna, a bátyám, aki már nem él szegény és én is biztos ... annak idején ... tehát egy ilyen család voltunk, aki nyitott volt a könyv fele. Ez nekem tényleg életcélom volt és amikor, kijutottam Magyarországra, hogy én Budapesten éljek 12 osztállyal hát nem tudtam elképzelni."194
\end{abstract}

\footnotetext{
${ }^{193}$ We went at the Ojtuz, crossed the border and I see, in Lebény the first Hungarian village, and is written paine and kenyér (bread both in Romanian and Hungarian), and then when I was 13 I realized for the first time that Hungarian language is a written language. And then as the villages came, even in Brassó there were several Hungarian labels, so I am going to tell the honest I was shocked, but only to realize that the language we spoke at home is a written language.

${ }^{194}$ In my childhood by the hominy (a traditional Csángó food, a siple form of polenta)we listened my older brother's lecture about Seneca, Kant, etc. Our family indeed was a literate family on one hand, on another hand we were all good learners. Four out of seven we would definitely graduate university and definitely at least two would have done the $\mathrm{PhD}$, my brother who is not alive anymore and me for sure ... back then ... this kind of family we were, opened towards the book. For me it really was a life goal and when I ended up in Hungary, to live in Budapest with 12 grades was unimaginable to me.
} 


\title{
5.7. The folk singer and artist
}

One of the best known Csángó artists currently lives in Hungary, where she graduated art school, from where she managed to have exhibitions and performances all over the world. (older than 51 current leader living in Hungary) Left the village in the mid of the 70's, with the purpose of learning. Before that, only boys went to school in other locations. In 72 a new decree was brought forward, the compulsory education was of 10 classes. In classes 9-10 there were only girls in the class because boys were taken to schools in Călugăreni, Gyergyó, and Balánbánya. There were no similar opportunities for girls, until a teacher from the village, offered to search some schools where they could learn. They offered her to find a location to continue her studies too. Before that, she had no plans in this regard, in the village it was fit to get married fast. Going to school first was just an opportunity of not getting married. At the beginning she did not even tell her plans to her parents; she borrowed the money that she had to pay the teacher in order to find a school.

\begin{abstract}
„A tanár visszajött és mondta, hogy elvették a papirokat Hétfaluban, Electroprecizia iskalába, 6 leánynak oda vették be a papirait és valamennyi másnak Sepsiszentgyörgyre. Mikor elmentük legalább 15-en kísértek el minket... de addig! Addig, édesanyám is jött velem. Nem tudom, hogy a többiek mért kisértek, de édesanyám azért, hogy lássa meg, hátha visszacsal, sirrt aztán szegény mindennel próbálkozott, de én annyira örültem, hogy bevettek abba az iskolába. Apám nem is akart hallani róla, haragos volt nagyan." ${ }^{195}$
\end{abstract}

Having the best results from the Csángó girls she was selected in a different class, with a profile of Electrotehnic. When the names of students was shouted, she didn't even notice who's Hungarian and who's Romanian, but someone told her that she is a Csángó. Being among the first girls who left the village to study and being disapproved for this decision by her father doing well in school was a high motivation.

\section{„Aztán én nagyon bizonyitani akartam édesapámnak, az volt az egyetlen lehetőség nekünk lányoknak, hogy kimenjünk a faluból akkor. Mi hét testvér voltunk és akkor jött a nyolcadik gyermek, úgy hogy ilyen iskoláztatás még az álmodban sem. ",196}

While doing the first year in Hétfalu she realized that regardless of school successes the profession she was learning was not the right one. She asked for permission to go

\footnotetext{
195 The teacher came back and told us that our papers were taken in Hétfalu, in a school with electronic profile, papers of 6 girls were taken there and for others in Sepsiszentgyörgy. When we left at least 15 came along with us ... until there. Until there, my mother came with me. I don't know why my mother came with me, to see if she can convince me to go back, she was crying, tried everything there, but I was so happy that I was accepted to that school. My father didn't want to hear about it, he was very angry.

${ }^{196}$ Then I really wanted to prove to my father, it was the only option for us girls, to go out the village. We were seven brothers and the eighth child was on the way, so education like such, not even in your dreams.
} 
regularly to masses, because she was allowed only occasionally and a teacher suggested that she should write a special request which was later granted and this permission had another beneficial increment.

„Egész évbe kimehettem vasárnap misére. Jártam a misékre s közben, ahogy jöttem láttam ott, hogy Scoala Populara de Arta (Népi müvészeti iskola) s ott ... találkoztam Klement Bélával és 3 évig oda jártam az ő osztályába, grafikára." 197

Since the discovery of the Popular School of Art, her life path is leading through these fields. There was a festival for amateur actors and a theatrical poster prescription was joined to it. Although the polish artists at that time were really good in that field, she was noticed and was awarded with the first price.

\begin{abstract}
„Engedélyt kértem, hogy elmenjek. Nem akartak elengedni és engedély nélkül elmentem. Ez 88-ban volt. Mikor visszajöttem olyan cirkusz lett az egészböl, hogy otthagytam a munkahelyemet. Volt két kicsi gyermekem, mindig egy - két testvér lakott nálam s akkor ott hagytam az egészet és csináltam egy magán mühelyt, ilyen japán hangulatú, ilyen virág ... festettem. A 90-es évek engem úgy fogtak meg, hogy magán, szabad ember voltam."198
\end{abstract}

After the regime change she got involved with the Csángó organization. Later the International Preparatory Institute was initiated in Budapest, where 10 places were allocated to Csángós. After finishing the preparatory year she applied to the University of Art, where she graduated with distinction. Living in Hungary and working as an artist, she feels a duty toward her community. Because of this feeling of duty she is not satisfied about how things turned out after the regime change. She feels that they should do more for their community, for those who are still at home. Everyone should act regardless of profession or education - firstly in the benefit of his/her family, but on a second level for the entire Csángó community.

„Avval szolgálhatom az ügyet, magamat és mindent, amit kaptam az Istentöl. Én a hiten keresztül rengeteg választ kaptam. És ha én ezt a talentumot kaptam, akkor én evvel kell foglalkozzak, de úgy, hogy abból induljak ki, ami vagyok. Jobbat nem tudok, nem tudok." 199

\footnotetext{
${ }^{197}$ For the whole year I could go out to masses on Sundays. I went to masses and meanwhile as I returned I saw the Popular School of Art, and there I met Klement Béla, for three years I went to his classes, to graphic.

${ }_{198}$ I asked for permission to go. They wouldn't let me go, so I left without permission. This was in 88 . When I came back it was such a circus, that I left my job. I had two little children, always one or two brothers were staying at me, and I quit my job and opened a private workshop, with Japanese feeling, with flowers ... painting. The nineties get me being a private, free person.

${ }^{199}$ I can serve the matter, myself and everything with what I received from God. A received a lot of answers through faith. And if I received this talent that I have to deal with this, but in a manner, that I start from what I am. I don't know better than that, I don't know.
} 
Second portrait (older than 51 current leader living in Moldova) is of a teacher and folk singer, who lives in Moldova, often has performances in Hungary. After finishing the first four classes in the village, continued her studies in the music school in Bákó, where she also graduated in a pedagogic school as a teacher. At the same time she was learning in the Popular School of Art, studying canto. She remembers that her teacher wished to prepare her for Conservatory, but her father said, that the pedagogic school is all he can afford and had no more money for further education.

Since childhood she liked to sing, her first performance being at the end of the first class. In those days it was a competition for scholars called Cântarea României (The Singing of Romania) which was organized, on local, county and national level. She was second at national level. All these performances were in Romanian, there were no places where she could've competed or performed in Hungarian. Learning the Csángó folksongs is closely related with the everyday life of the village.

\begin{abstract}
„A magyar énekeket mind hallottam, mert mentem édesanyával én is guzsalyosba, vitt éngemet is, vagy este mikor mentünk törökbúzát tisztitani akkor meséltek, énekeltek az asszonyok, imádkoztak. Magyarul csak itten hallattam ilyen kalákákba, vagy a lakadalomból mikor jöttek haza. Abba az időbe az úton énekeltek, biztos a lakadalomba is, de én oda nem jártam. Az úton mikor jöttek haza, akkor énekeltek magyarul."200
\end{abstract}

In 1988 she had the opportunity to attend a Christmas ceremony in Hungary organized by father Jáky Teodóz. Among different Csángó songs she heard one, the “Oh, Szent István Dícsértessék ...", the song of Saint Stephen, about which she found out that it was collected by Pál Péter Domokos in her own home village. Not knowing the song, as soon as she returned home she started an investigation in order to find someone who could teach her.

\footnotetext{
„,Vannak a jó énekesek, akiknek a fejükbe maradott, mert nem tudtak írni, olvasni. Csak ami a fejébe maradott annyi volt, nem volt az leirva sehol. Mondták, hogy tudnak róla, de nem emlékeztek. Azt mondták, hogy mikor a búcsú napja volt énekelték magyarul, mert latinul mondták abba az időbe a misét, magyarul énekelték a Szent István éneket a búcsú napján, a misén, de nem tudták, nem emlékeztek, mert az rég volt, amikor volt. De végre
}

\footnotetext{
${ }^{200}$ I heard all Hungarian songs, because I went with my mother to distaff (a gathering where members if the community work together), she took me along too, or at evening when we went o clean the corn, the women were telling stories, singing, praying. In Hungarian I only heard in these gatherings, or when people were returning from weddings. Back then, they were singing on the street, probably at the wedding as well, but I was not participating. On the street, when they were returning they were singing in Hungarian.
} 
eredményesen jártam, mert felkerestem Kicsi Katalint, aki a kántornak a lánya volt és ö még emlékezett erre az énekre, elénekelte. Két szakaszt tudott belöle. "201

An important event is linked to this song:

„91-be volt lehetöség Domokos Pál Pétervel találkozni, s akkor én nagy büszkén mondtam, né, mit tudok, s ki is énekeltem, elmondtam, solyan boldog volt, rám nézett, meghallgatott. Felkölt, s a könyvtárához ment és azt mondta, hogy na itt van egy könyv mibe meg van ez az ének. Kinyitotta, irta lent Domokos Pál Péter gyüjtötte 32-ben, Pusztinából. És ott megvolt a harmadik szakasz, így összeállt a Szent István éneke. Megtanultam, de aztán, visszatanitottam az egészet, most mindenki tudja a Szent István Dicsértesséket." ${ }^{202}$

All these experiences were prior to the regime change. The joint benefit of the search up of songs and the regime change is, that after the borders were opened, brought several people to Moldova, and Csángós to Hungary as well, and turned the interest of Hungarians toward the Csángó culture. Getting acquainted with the Tatros group they joined forces in order to find those people in the village who beside the songs, also know the dances and the music that was once played. Relearning and bringing back the songs, music and dances into the life of the younger generation and into those who were interested in this culture a considerable táncház (dance house) movement began in Hungary. Having the great interest from Hungary toward the Csángó folk culture is of great importance but the urge to have something at home that could provide the opportunity to teach the young generation the forgotten songs and dances of their ancestors was something that could not wait.

„Nekünk itt kellene, hogy ezek ismerjék meg, mert éreztem azt a veszélyt, hogy ha nem tanitsuk vissza, és nem lássák itt ezt az egészet, meg is tagadják, hogy nem ezek a moldvai táncok vagy énekek, vagy ilyesmi. Mert nem volt lehetöség, hogy hallják sehol. "203

\footnotetext{
${ }^{201}$ There are the good singers who kept all in their minds because they could not write or read. Remained, only what they kept in mind, there was nothing written. They said, that they know about it, but can't remember. They said, that in day of farewells they sang it in Hungarian, because back then masses were in latin, and sang the Szent István song on the day of the farewell, on masses, but did not know it, could not remember, it was a long time ago. But finally I was successful because I visited Kicsi Katalint, who was a doughter of the cantor and she still remembered this song, and she sang it. She knew two pharagraphs.

${ }^{202}$ In 91 I had the opportunity to meet Pál Péter Domokos, and they I proudly said, here is what I know, and I sang it, he was so happy looked at me, and listened to moe singing. He walked to his library and said that here is a book with this song in it. Opened it, and it was written at the bottom, that collected by Domokos Pál Péter, in 32 in Pusztina. The third pharagraph was there, and as such the Szent István song came together. I learned it, and they I reteached it, now everone knows the Oh Szent István Dicsértessék.

${ }^{203}$ We need it here, for them to get to know these, because I felt the jeopardy that if we don't reteach them, and they can not see these here, they will deny that these songs and dances are not from Moldova, or something similar. Because they had no opportunities to hear them anywhere.
} 
First this was done by some enthusiastic volunteers then reenactment received an important role in the education program of the MCSMSZ. Considers that is a great success that through education can teach back songs, dances to children. Nowadays with the Hungarian teaching and the teaching of cultural aspects for children the negative feeling is somehow moderated but she remembers cases when those who performed in Hungary either as singers, either as dancers were threatened by others from the village. She thinks that in the teaching of the young generation a major role should be given to the cultural aspects, and teachers of the MCSMSZ should and could bring together those - older - persons who still know the customs, the songs and who are the last keepers of the culture with children, with the young generation. The attitudes toward reenactmenters and those who have Hungarian feelings is still divided, some could not grow out of the hostility while others although were hostile if the children liked to attend Hungarian classes by the time they have changed, they had performances in the village as well, but was no great success.

\begin{abstract}
„Hogy mindig mentünk énekelni, még meghivtak, hát voltak olyanok abba az idöbe Romania Mare, s Vadim Tudor, s miegymás, úgy össze-vissza zavarta az emberek agyukat, plusz a pap is még, hogy fenyegettek avval is, hogy ha még sokat szégyengessük a falut, betörik az ablakokat s mind meghajigálnak. Úgy mondták, hogy szégyengessük a falut, az énekvel és a táncval miket mi elöadunk ottan." ${ }^{204}$
\end{abstract}

Now folksong and recite competitions are organized, and some children after participating and winning on these events are applying to universities continuing to keep their traditions. Having kids at music schools and academies are irrefutable results. In the educational system results can't be seen during 1-2 years, she would be happy about the results of her work, if some of her students would turn back and continue her work of teaching, the work of reenactment. Reenactment implies several generations: those who are thought, those who are teaching and in this case those who are the livingwalking memories.

\footnotetext{
${ }^{204}$ As we went all the time to sing, we were invited, back then there were the Romania Mare (a nationalist Romanian political party, leaded by Vadim Tudor), confused the mind of people so badly, and the priest too, that we were threatened that if we continue to shame the village, they will break our windows, and will throw at us. That is what they said, that we are embarrassing the village, with the songs and dances that we present there.
} 


\subsection{The folk musician}

The first musician presented is a young Csángó (36-50 years old employee living in Hungary), who left the home village at the age of 16, remembers the feeling of dropping from a Romanian sea which is Moldova, into a Romanian ocean in Oltenia. Getting in a dorm of Hungarians from all over the country was beneficial in several aspects.

„Egy nagyon jó kicsi társaság volt ott, olyan 8 - 10-en voltunk magyarok ott, és igazából Olténiában tanultam meg magyarul írni, olvasni, úgy becsületesen és beszélni szépen magyarul. Mert ezt az otthoni magyar beszédet tudtam, de azon rajta van az oláh hatás. "205

After graduating he planned to leave the country but the regime change brought new hope, that things will get better, because even while he was younger he felt the life and the political situation in Romania as a huge pressure.

„Én úgy készültem, hogy elmegyek. Aztán jött a változás, ami elég erösen érintett, mert éppen Temesváron dolgoztam. Kezdésnél, úgy gondoltuk a legjobb barátommal együtt, hogy nem megyünk sehová, most mát itt is vége, demokrácia van. Majd megyünk utazni a világba, de nem megyünk dolgozni, maradunk épiteni az országot.,"206

After only half a year with the conflicts in Bucharest - which he attended realized, that there is no big change, so the thought of leaving the country was actualized again. He planned to go to France, than to Canada with the help of some friends who previously were helped by him to get to Canada. On his way to Canada he stopped in Hungary where in that time the folk dance houses were very famous, it was the time of the Táncház (dance house) movement.

„Magyarországon megtalálkoztam ezzel a fránya táncház mozgalommal, úgy belevetettem magam, hogy most is ott vagyok.",207

Learning all dances from his parents in Moldova and by going to Táncház weekly and seeing there, how many people are interested in the dance culture of Csángós, it was a very positive thing. The initial thought of coming for Budapest for only half of a year,

\footnotetext{
205 There was a good little group there, we were about 8-10 Hungarians there, and truly I learned in Oltenia to write and read fairly in Hungarian. Because i knew the Hungarian speaking from home but the Romanian influence is on it.

${ }^{206}$ I was preparing to leave. Then the change came, which had a great impact on me, since I was working in Temesvár. At the beginning, we thought with my best friend that we are not going anywhere, now its I over here too, it is democracy. We will go to travel around the world, but we don't go to work, we stay and build the country.

${ }^{207}$ In Hungary I met this damn dance movement and got so plunget in it, that I still in it.
} 
then go to France and Canada, changed. He remembers that back then, the guest working in Hungary for Csángós was very well organized.

„akkor meg volt szervezve, mondjuk kihoztak ide száz csángót, akkor öket időnként hazavitték busszal, vagy vonattal és visszahozták. "208

He was helped by previous migrants to come along but as he says he never travelled with them home or back, had his own ideas about living in Budapest. He was helped but, he helped back, had a great advantage compared to other Csángó guest workers, namely that he could read and write in Hungarian. He had several jobs, around different parts of Hungary. While working in Jászberény he took part in the organization of the Csángó festival that is held yearly. Besides being a musician who represents Csángós on several events, is working as a carpenter, although he has a university degree can't give up on working with wood.

"Közben folyamatosan a táncház mozgalom részese vagyok. Zenélek is, most is onnan jövök a békéscsabai fesztiválról. Szóval úgy erösen propagálom a csángó kultúrát. Ebböl már nem lehet megélni, már régóta, de nagyon szép pillanatokat adott.

He feels that he has a lot to thank to this movement could not tear up his origins as it regards work, has to work in the field, with wood, etc., and he did that even when it was possible to live from the dance movement and from the csángó culture.

\begin{abstract}
„Amikor nagyon jól ment a zenélés, akkor is, az egy jó pár évig volt, amikor országosan támogatták, akkor is egy - egy tetöt bevállaltam, hogy legalább valami, a famunkát, a fürészpor illatát érezzem meg, tényleg ez hiányzott és akkor bevállaltam. De van földem is, ezeket a gyökereket nem tudtam elvágni, szükségem van, hogy kapáljak, szükségem van, hogy kaszáljak, mezitláb járkáljak a földön. Nem volt akkora szükségem, de annyira jó volt mikor évente két, három hetet dolgoztam fával és akkor, volt megint eröm. ",210
\end{abstract}

\footnotetext{
${ }^{208}$ Back then it was organized, let's say they brought one hundred Csángós, then occasionally they were brought home and back with busses or trains.

${ }^{209}$ In the meantime I am continuously part of the táncház movement. I play music, I m right now coming from the Musical festival from Bekescsaba. So, I am strongly propagating the Csángó culture. It is not possible anymore to make a living out of this, but gave me very nice moments.

${ }^{210}$ When music was going well, even then, for couple years, when it was nationally funded, I undertook a roof, just something, the woodwork, to feel the smell of sawdust, I really missed that so I undertook. But I have land to, I could not cut these roots, I need to hoe, I need to scythe, to walk bare foot on the land. There was no big necessity, but it was so good, if I was working for 2-3 weeks in a year with wood, then I had power again.
} 
Second portrait (older than 51 employee living in Moldova) of a Csángó musician is of a member of the older generation who lives in Moldova, yet often participates to events organized in Hungary as well. He is active in the music teaching of the young generation both in Moldova and Hungary. Graduated 7 years in the village's school, after which he got a degree as a carpenter and worked in a furniture factory. He is recognized in Hungary and Moldova as well, for playing original Csángó music on flute, recorded several CD-s in Hungary.

„Nem a furulya volt igazán az én szakmám, nem ebböl éltem és nem ebböl élek most sem. Ezt hobbiból, mert nagyon szeretem. Édesapám is egy jó furulyás volt ebben a faluban, egy legjobb volt igazából. ",211

Although he started to play on flute when he was 5, for many years music had to be set aside, work and taking care of the family had definite priority. He remembers that music came back with a spinal disease, when he had to go to spa, and between treatments had time for practice.

\begin{abstract}
„Ötévesen kezdtem el furulyázni, akkor kezdett el apám velem foglalkozni, még az ölébe vett fel, mert kicsi voltam és nem tudtam az ujjaimat rakni, raktam az övéire mig kicsi mozgást kaptam az ujjaimnak. Azután, mikor látta, hogy valamit tudok, adott egy notát hogy tanuljam meg. Így lassan tanulgattam meg ... akkor csak mind hallásból, meghalltam ugye a mezön, de inkább lestem a cigányokat vasárnapként a táncba. "212
\end{abstract}

After bringing back all those songs once he heard, now is teaching the young generation, children of 8-10-14 years old. He says that he can be proud of them, because they attend different competitions and events, and perform well on stage as well. These are the things and the moments that motivate him in teaching.

Attending several musical events, teaching from Moldova to Poland, and performing from Romania to Germany, and having three CD-s has a good insight on the interest toward the Csángó music culture. When asked where were the CD-s recorded he said that in Hungary, because there is a greater interest than back home.

From the variety of performances we can see that interest seems higher abroad than in the native location of the specific culture. When asked in what stands the

${ }^{211}$ Playing the flute wasn't my real job, did not provide livelihood for me, still doesn't. I do this as a hibby, because I love it very much. My father was a very good flute player in the village, one of the best actually.

${ }^{212}$ I started to play the flute when I was five, then my father started to teach me, took me in his lap, because I was small I could not put my fingers so I've put on his fingers until I got some small movement for my fingers. Then when he saw that I know something, a song to learn it. Like that slowly I learned ... then only from hearing, I listened on the camp, but mostly I peeked at the Gypsies in Sunday in dances. 
problem that leads to this, to the fact that Csángó folk - music and dance - culture has a higher status in Hungary, he mentioned several aspects, educational, economic and political as well.

"Nagyobb értéke van, mert ugye nálunk itt sajnos nincsenek rendezvények, nincs hol találkozzon a népség, ugye mi alig tudunk annyit hogy 8 osztályig fenn, azokkal még tudunk foglalkozni, de a nagyobbakkal nem mert mennek el munkára, mennek iskolába aztán tovább munkára. ${ }^{, 213}$

There is an initiative in Nagypatak, where the brother of the mayor organized a group - with 10 pairs - who are attending a dance competition. He sees this as a start, as a first step. The strange thing is that it happens only in one village, in Klézse, one of the biggest villages, where the folk culture survived in the biggest proportion these kind of innovations are missing. He sees the surviving of the folk culture in the work of couple individuals rather in the way of living of the community.

"Minek maradt meg, mert édesapám vót egy furulyás ki ezeket ugye bekonzerválta, utána vettem át én, és én is úgy bekonzerváltam ezeket az én dalaim. Ezeket a dalokat nem zenélte elöttem senki. ${ }^{214}$

One negative feed-back he received was that some called the music he play Romanian, and cannot understand the great interest toward it, if it is Romanian. Another negative aspect is that he sees that after a while the original musicians of the Csángó folk-culture are set aside and those who learned this music from them are stepping in their places. Considers that Csángós are a business in Hungary and Transylvania as well, with national support and tenders, but he also sees that these funds are not always reaching Csángós and Moldova. They applied for a support to create some jobs in the village, but became obvious for them that funding is not so clear and reachable and has many conditions and preconditions that are hard or impossible to fulfill.

\footnotetext{
${ }^{213}$ It has a greater value, because here we don't have events, there is no place where people to meet, we can only do up to the $8^{\text {th }}$ grade, we can deal with them, but with older ones, no, because they leave to work, or to school and then to work.

${ }^{214}$ Why was it kept, because my father was one flute, who conserved, then I took it over, and I conserved my songs too. These songs were not sung before by anone else.
} 


\title{
5.9. The local teacher, the reenactmenter
}

Current subject (older than 51 employee living in Moldova) started her life-path and self-presentation by saying that her father and grandfather were folk artists, were among those few people who made a sort of pelisse that is part of folk costumes. They learned only five classes but they learned in Hungarian which had a great influence on their family and on her as well.

$$
\begin{aligned}
& \text { „Nálunk magyarul vot a Biblia az asztalra letéve, nagyapám mindig úgy olvasott: } \\
& \text { magyarul. Úgyhogy én tudtam olvasni, azért is alakult igy nekem, ez nem véletlen vot ez a } \\
& \text { magyarsághoz való kötésem." } 15
\end{aligned}
$$

After the death of the grandfather the father was not able to maintain the family from his trade, so he started to work at the railways. She said that seeing her father once in a month and having a very religious mother had great impact on her life.

\begin{abstract}
„Jártam mezöre anyámval iskolás koromban, ö járt kollektivba, mük mentünk a kecskéket örizni. Abban az idöben úgy vot, hogy a mezön mindent elbeszéltek, mert együtt voltak mindennap az asszonyok. Az emberek, ha dolgoztak is a kollektivba, azok nem sokat voltak igy echipaba (csoportba), hanem úgy jártak vagy az állatoknál a zootechnicaba, vagy mit tudom én félre voltak szekerekvel, béállva csak asszonyok voltak, sokan votak egy 15-20 egy echipába (csoportba). Mindennap mentek s ott énekeltek s mindenröl meséltek és mindent mondtak, hogy vót ezelött hogy van most, mi miljen virág, miféle, minek hiják s minek való miljen betegségnek. Mindenféle iljeneket tölük tanultam."216
\end{abstract}

Being one of those who know a lot of the old folk songs and teaching the young generation has a lot to thank for those women who by working on the fields though her so many things.

\begin{abstract}
„Én úgy nöttem meg, hogy ezek között vótam. Az éneklést, azt nem mondom, hogy mennyi sokat, még most es egy-egyszer eszembe jut egy oljan mi rég nem jutott eszembe csak úgy felbukkan. Vótak vagy ötön abba az echipába (csoportba) hova anyám járt, hogy nagyon szépen énekeltek, szép jó hangik vót, és szerették erőst, énekesfélék vótak, vigadós népségek.
\end{abstract}

\footnotetext{
${ }^{215}$ We always had the Bible put on the table in Hungarian; my grandfather read it like that: in Hungarian. So I knew to read, this is why it turned like that, my connection to the Hungarian identity was not by chance.

${ }^{216}$ When I was in school I went to the fields with my mother, she was going to the collective we went to guard the goats. Back then they spoke about everything on the camps, because women were together everyday. Men if they were working in the collective, they were not in teams, but went with the animals to the zootechnique, or were in other places with the carts, in teams it was only the women, they were about 15-20 in a team. They were going everyday and they were singing there and saying stories about everything how it was before and how is now, the type of flowers, what are they, how are they called to what disease are they good for. All these things I have learned from them.
} 
Azok felviditták az egész echipát. Sok megmaradt nekem, onnan ered nekem ez a hozzáállás." ${ }^{217}$

In each village stores were opened where she was asked to work, but not having confidence and a good opinion about the president of the cooperation, she choose to go hoeing. When she was 21 she got married, and considers that her life took a turning after that. In the first 10-15 years of her marriage, having small children she attended no events which was a huge change.

„,addig mindig jártam, mentem mindenüve ahol vót, a caminba (közösségi ház) valami, vót a faluba-brigada artistica (müvészeti brigád)- úgy mondták akkor s ott vótak táncok s ott vótak énekek. Én mindig elvoltam menve vagy a templomnál vagy a caminnál vagy a kollektivnál votam. ${ }^{218}$

She was reading in Hungarian from early ages, but had no reason to learn how to write in Hungarian. Remembers that back then when someone died, women were singing at the coffin. They had an old scribe, who was their neighbor who always had to go to sing. Not able to see everything he brought the young girl to sing along or to say the words of the song.

\begin{abstract}
„92.-ben vot legutolján mikor még így magyarul énekeltek a halottnál, azért hogy azután megholt az öreg deák ameljik vot a faluba s jött kettö iljen ifjú, még húsz esztendösek sem vótak. A pap azokat kitanittatta, hogy tanuljanak meg orgonálni, hogy legyen ki orgonáljon, legyen deák a faluba s azok mivel az eskolába ólául tanultak s inkább tudtak beszélni, de nem tudtak olvasni, nem tudtak iljen régi öreges énekeket. "219
\end{abstract}

It was a period when at the watch first they sang the Romanian songs they learned from the books later they sang the Hungarian ones they learned from their forefathers. She remembers that there were the older women, with whom they stand at the end of the watch. They got together 5-6 and they sang "those nice sad songs". They were singing until 1-2 or even 3 o'clock in the night and in summer time until morning. Previously it was a custom that the dead cannot be left alone.

\footnotetext{
${ }^{217}$ I grew up by being among these. Singing, I am not telling how much, even now songs which I did not recall for a long time, just pops up. There were about 5 people in that group where my mother worked, who sang very nicely, had good voices and loved very much, they were singer type people, party folks. They cheered up the whole group. Many things remained to me,from there I have this approach.

${ }^{218}$ Until the, I was always going wherever something was organized, in the cultural house, in the village called the artistic brigade - and there were dances and singings. I was always gone somewhere, at the church, at the cultural house or at the collective.

219 ' 92 it was the last time when there was Hungarian singing at the dead, after the death of the old cantor of the village, two young ones came, they weren't even 20 years old. The priest thought them, taught them to play the organ, to have someone who plays the organ, to have a cantor in the village, and since they learned in school in Romanian and could speak but could not read, did not know these old songs.
} 
Nowadays those who know those old songs and customs are well above 70 years old. That is why she considers handicraft, songs and dances and beside that some doggerels, the most important lesson that children need to be taught.

The usage of the Romanian language is very influential, being close to Bákó, at only $15 \mathrm{~km}$-s some parents are bringing their children to schools from the town as early as first grade. Starting their education on extracurricular classes as soon as possible is vital. Children of 6-7 years, starting school can speak Hungarian, know songs and poems. Not attending these classes they would have never learned the language, in the best case they would understand what and how the parent speak, but would have never used the language confidently. She remembers her grandfather reading about Saint Paul and other stories, all in Hungarian this is why she tells to her student that:

„,tudják meg nekünk ez a magyaros, ez lenne az anyanyelvünk,"220

Organizing events is not typical only to the young generation. Organized dinners and gatherings (the already mentioned "kaláka" or "guzsalyas" where the community works together) just like she saw it was done before. She feels that this kind of work is not only accepted and appreciated by the MCSMSZ and outsiders but is participated and enjoyed by neighbors, by villagers. Being able to say stories about their past, about how their parents and grandparents lived means a lot, and the hope that children who heard the stories will be similarly able to transmit this knowledge for the further generation makes her role even more significant. Oral tradition still plays, or at least in the transmission of the Hungarian culture an important role among Csángós.

${ }^{220}$ They should find out, that for us, this Hungarian, this would be out mother tongue. 


\section{Elite definitions}

To answer the question who is the Csángó elite and why exactly them, hypotheses were grouped around theories - migration and social network positioning and investigation methods - interview, survey and social network analysis.

I supposed that members of the Csángó elite will fulfill the roles of opinion leaders and broker, and in the Csángó matter network they are rather working together than competing, due to the common goal of preserving the Csángó culture. Meanwhile they have migration experience - they were studying or working for several years in Transylvania and/or Hungary - and occasionally are living in other places than Moldova or even Romania. For those who do live in another country - mostly in Hungary - the roles and positions they have in the Csángó matter will have higher value than for those who are in Moldova.

Following figure seeks to present how the theoretical approach is underlined by Hypothesis, by operationalization. As it concerns the theoretical approach, the topic of the dissertation is at the intersection of elite theories, social network analysis roles and positions theories and migration theories, in the empirical part social network analysis and migration experience narratives are used to defined the Csángó elite.
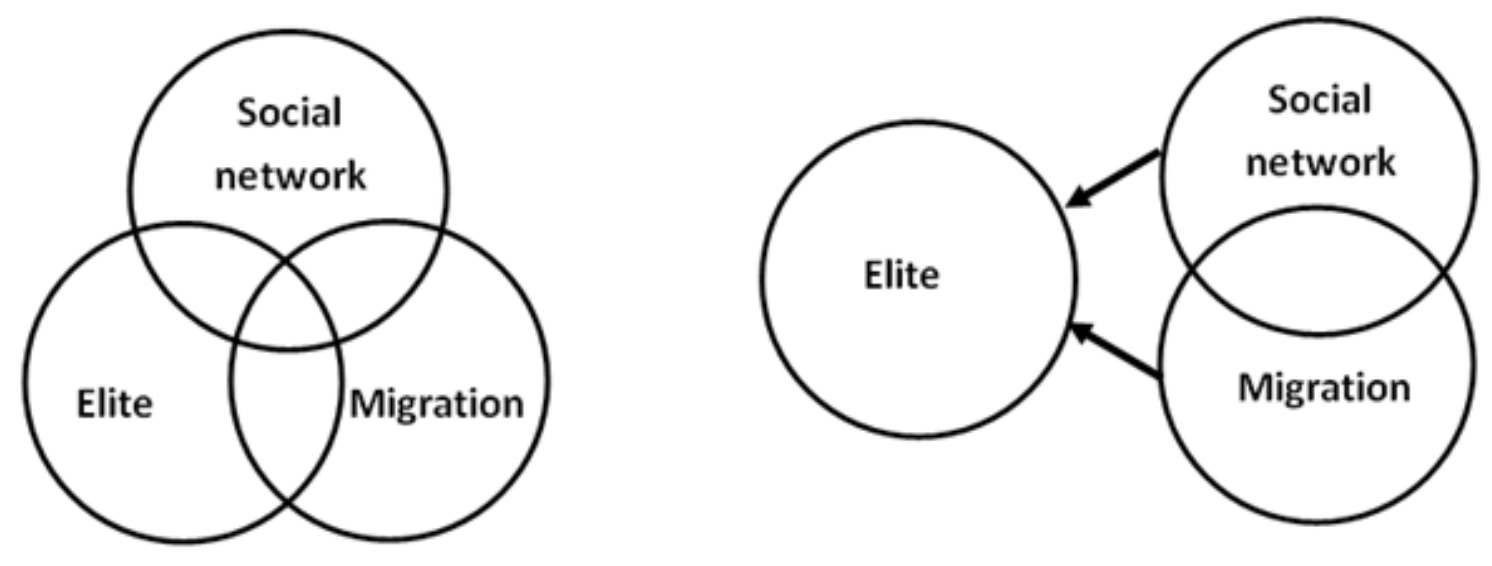

Figure 7: Theoretical approach

The goal is to present the elite as they see themselves in playing the most important role the "duty toward the Csángó community", the activity in the Csángó matter. After presenting their network characteristics, migration experiences will be analyzed based on interviews and finally the cross section of social network analysis and migration experiences are in focus. All along it is important to see whether the community is acknowledging and sustaining their elite position. 


\subsection{Hypothesis 1: Elite defined by roles and positions in the Csángó matter cooperation network}

Motto:

"Social networks have value precisely because they can help us to achieve what we could not achieve on our own. [...] Social networks, it turns out, tend to magnify whatever they are seeded with. [...] Some scholars explain collective human behavior by studying the choices and actions of individuals. Others dispense with individuals and focus exclusively on groups formed by social class, race, or political party affiliation, each with collective identities that cause people in these groups to mysteriously and magically act in concert. The science of social networks provides a distinct way of seeing the world because it is about individuals and groups, and about how the former actually become the latter."

(Christakis \& Fowler, 2010)

Previously the Csángó elite and the Csángó matter was presented, focusing on how these two are connected, specially on the role of elites and how they see their duty toward their communities of reference. The current subchapter seeks to analyze relational aspects- through cooperation networks, focusing on events and organizations - of the Csángó matter. Several levels and layers will be visually presented and analyzed, focusing on the role - in network terms - of elites in the Csángó matter, especially their social capital and whether their positions of formal leadership are sustained by the network structures. It is also important to present the magnitude of the Csángó matter, which not only implies and involves several individuals and organizations but a wide geographical area as well.

Networks will be presented using the layering suggested by Szántó and Tóth, according to whom we can speak about network of individuals, networks among organizations and networks of regions. (Szántó and Tóth 1993:45)

At the individual level five networks were analyzed, the first is built up by interviewed elites and the relations among themselves, second contains all actors present in the first network plus their alters - all those people they named as working partners in events that concern Csángó topics. In network three, beside the former actors we included the representatives of organizations and their alters, while in network four we added some employees of the MCSMSZ, teachers who are active in the Csángó matter on daily basis. At the last network on this level - fifth one - not only egos and alters are connected, but according to the data revealed by egos, the alter-alter relations were also taken into consideration. In order to create this much ampler network, the Egonet program was used, which allowed the merging of all ego networks in a total or whole network regarding cooperation. In this whole network there are 482 actors with a total of 1777 relations. Presumably the most important relations are present. By starting the snowball sample from different persons other actors might have been included, with 
other nominations, or In-degree might have been slightly different, but supposedly the central figures would have remained the same.

Secondly the organizational level presents a two-mode network, in which affiliation of interviewees to organizations and/or events was analyzed.

The third level takes into account geographical regions. The country level basically is the same as network 5, yet the difference is given by the coloring of the network based on two attributes, on region and whether one is Csángó or not.

After going through these three levels the question whether key actors manage to maintain their central positions - based on In-degree, Betweenness and Degree - as more and more actors and relations are added to the cooperation network will be answered. As a following step the relation among network characteristics and elite nomination is analyzed with SPSS.

Finally, two network case studies are conducted in order to compare the networks of two competing groups, the MCSMSZ and the Barátikör. By presenting these two groups two statements that were often encountered during interviews shall be tested too. On one hand there is the opinion that the best solution for the Csángó matter would be to remove one specific actor, while the other statement is that Csángós living in Budapest should stay out from the Csángó matter, since you can’t serve your community from $1000 \mathrm{~km}$.

A wide variety of approaches are presented in this chapter to the simple question who are you regularly cooperating with, in topics concerning the Csángó matter. The relation among being elite and being the member of a social network is explained by one interviewee saying that people from the village are searching for her help not necessarily as intellectual, instead they would like to use her connections. Being part of a social network is useful for the community as well. One has a social network due to the life experiences one lived. 


\subsubsection{Individual level}

Key actors were determined using Centrality measures - In-Degree and Betweenness - and ego-net broker to see who are those who fulfill the bridge role in and among groups. Key actors calculated based on these measure, were coded with S1, $\mathrm{S} 2, \mathrm{~S} 3$, etc.

\section{Network1: Network of interviewed elites}

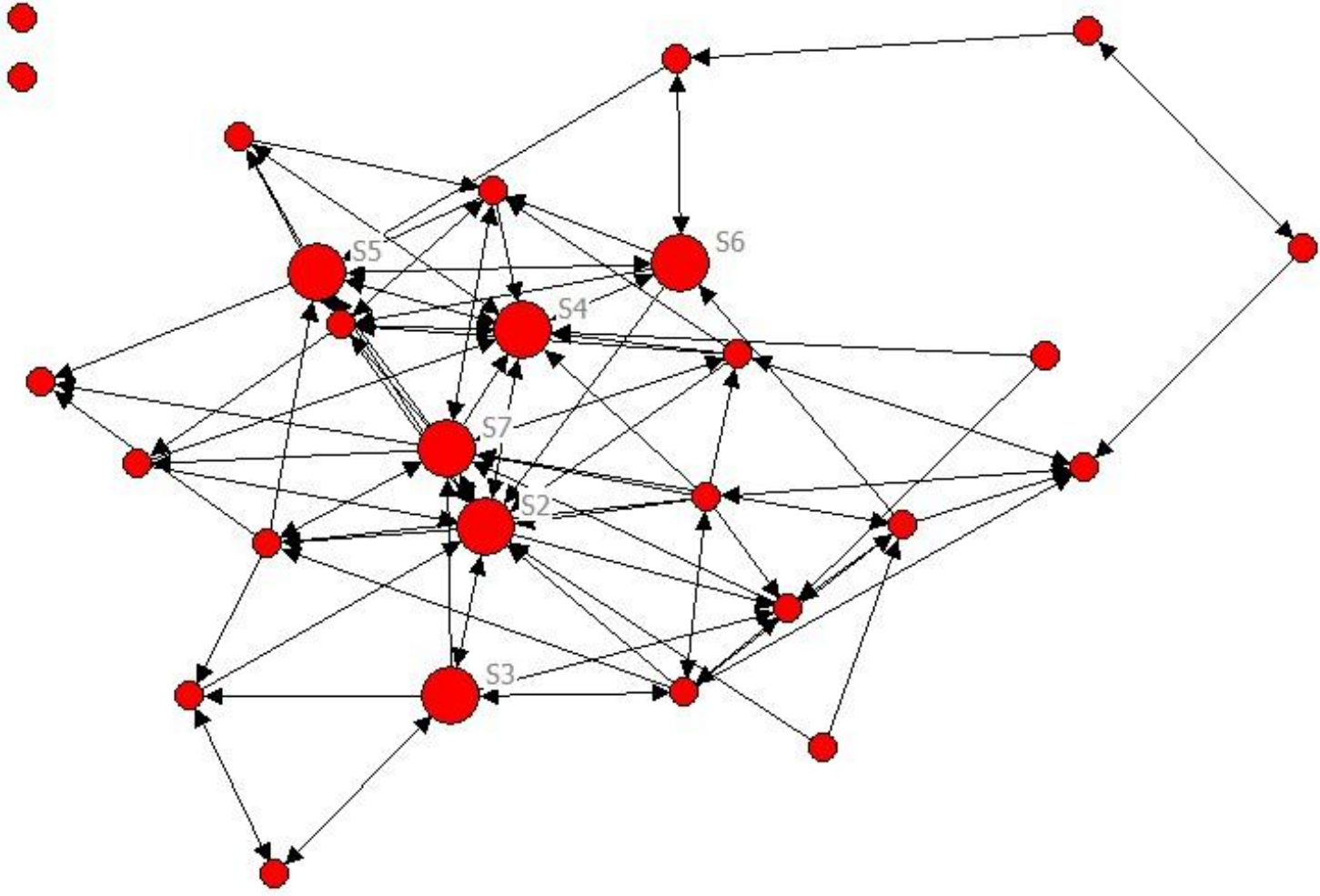

Figure 8: Cooperation network among questioned elite actors

Legend: • named actors, $\bullet$ central figure.

25 actors have at least one relation, with a total of 96 relations. There are two persons, named as elite who have no cooperation relations with any other interviewed elites. Based on centrality measures calculated by assuming that the network is symmetric, was highest in the case of S2 (14), S7 (13), followed by S4 (11) and S5 (9). In-Degree slightly changes the order, S4 and S2 having 11 relations while both S7 and S5 have 7 nominations. Betweenness supports the same two actors as Degree, on first positions we find $\mathrm{S} 2=126,692, \mathrm{~S} 7=111,132, \mathrm{~S} 3=61,142, \mathrm{~S} 6=59,958, \mathrm{~S} 4=57,183$. These actors in Burt's (1999) terms can be seen as opinion leaders and opinion brokers as well. The number of non-directly connected pairs was high in the case of S5 (17) and S6 (16) on one hand and S7 (49), S2 (44) and S3 (33) on another hand. 


\section{Network 2: elites and their alters}

To actors present in Network1 alters named by them were added, without the restriction that one has to be elite in order to appear in the network. The most important fact that needs to be observed is that almost all central members managed to keep their key-positions and another member gained central position (visualized with green). 183 alters and 342 relations were named in total. S2 (34) and S7 (32) kept their leading position as it concerns degree, beside them S3 (31) and S1 (22) are central. However degree is highly influenced by Out-Degree as well, and since the number of alters was not restricted to a specific number is wiser to use In-Degree. According to this centrality measure the same persons are in leading positions: S4 (11), S2(11), S7(7) and S5(7). The number of non-directed ties is higher in the case of S5 (89), S3 (75), S6 (52) on one hand, and S2 (241), S7(171) and S4(107). Betweenness points out the role of S2 (1604,735), S3 (1001,724), S7 (842,698), S4 (581,405), S6 (527,856).

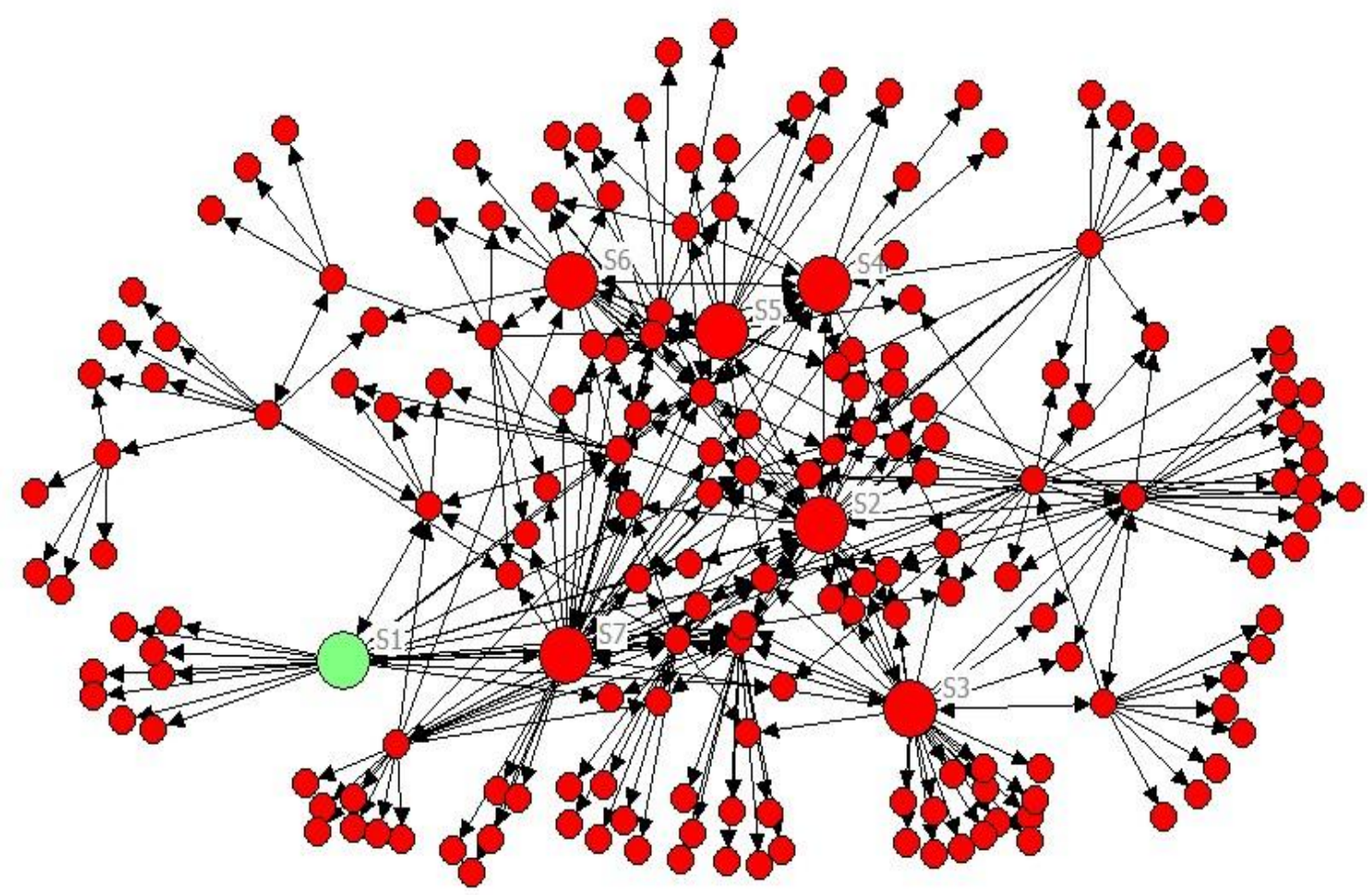

Figure 9: Cooperation network of elites and alters

Legend: $\bullet$ named actors, $\bullet$ central figure, became central in this network.

Actors kept their roles as opinion leaders and opinion brokers as well, and this is confirming Burt's (1999) theory that by fulfilling the diffusion of information between social groups as well, opinion leaders will be opinion brokers too. It is important to realize that speaking about transnational relations in some cases these actors are not linking only groups of people but geographic regions - or countries - as well. 
As mentioned earlier other members, active in the Csángó matter, are added in order to see how the new members will influence the network properties and the central roles of the participants. In Network 3 representatives are seen as the leaders (or one of the leaders) of an organization working in the Csángó matter. In Network 4 employees teachers of the MCSMSZ, who are active on daily basis in the Csángó matter, namely in the Hungarian teaching in Moldova - are added. The question needed to be answered is what actually matters: to be involved in the Csángó matter on daily basis or to be a coordinator or leader. If the central positions will be fulfilled by the same actors as in Network 1 and 2 then representing an organization is not enough, one has to be considered as elite by others. If central positions will be fulfilled by someone(s) from Network 3 and their role will not change in Network 4, then activity in the Csángó matter is strongly correlating with being the leader of an organization, and this relation could be more important than being member of the elite.

\section{Network 3: Network of elites, representatives (leaders) and alters named by them}

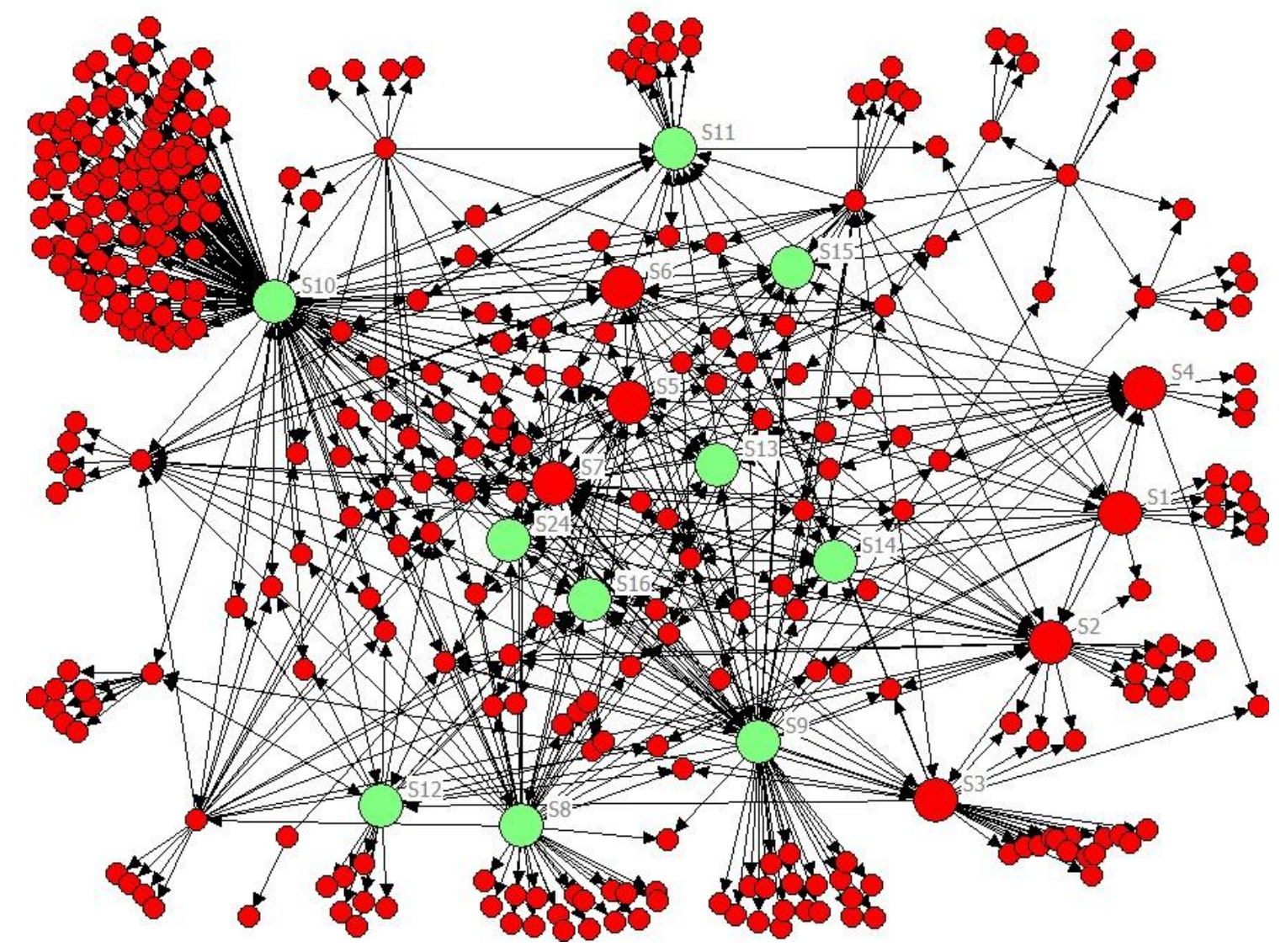

Figure 10: Network of elites, representatives (leaders) and alters named by them

Legend: •named actors, $\bullet$ central figure, $\bullet$ became central in this network.

After introducing leaders of important organizations and the alters they named in the network, the total number of relations is 638 . As we can see some members of the 
first networks kept their central position but new members, representatives - S8, S9, S10 - are central as well. Beside representatives other actors gained central position in this network, most of them are active members of the MCSMSZ from several years either as teachers, either in administration. According to In-Degree first two positions are kept by S4 (13) and S2 (12) followed by S16 (11), S5 (10), S11 (9), S15 (9), S7, S14, S13 all three with 8 nominations and S10 (7). S10 is a key figure in the MCSMSZ and the Hungarian teaching in Moldova. S16, S11, S13 are all employees of the MCSMSZ, while S15 is the representative of an organization in Moldova, S14 lives in Budapest and became a key figure of an organization in Budapest soon after the interview was conducted.

After including employees of the MCSMSZ, we will see that their position in the cooperation network, just as S10's position is strengthened.

\section{Network 4: Network of elites, representatives (not only leaders) and alters named} by them

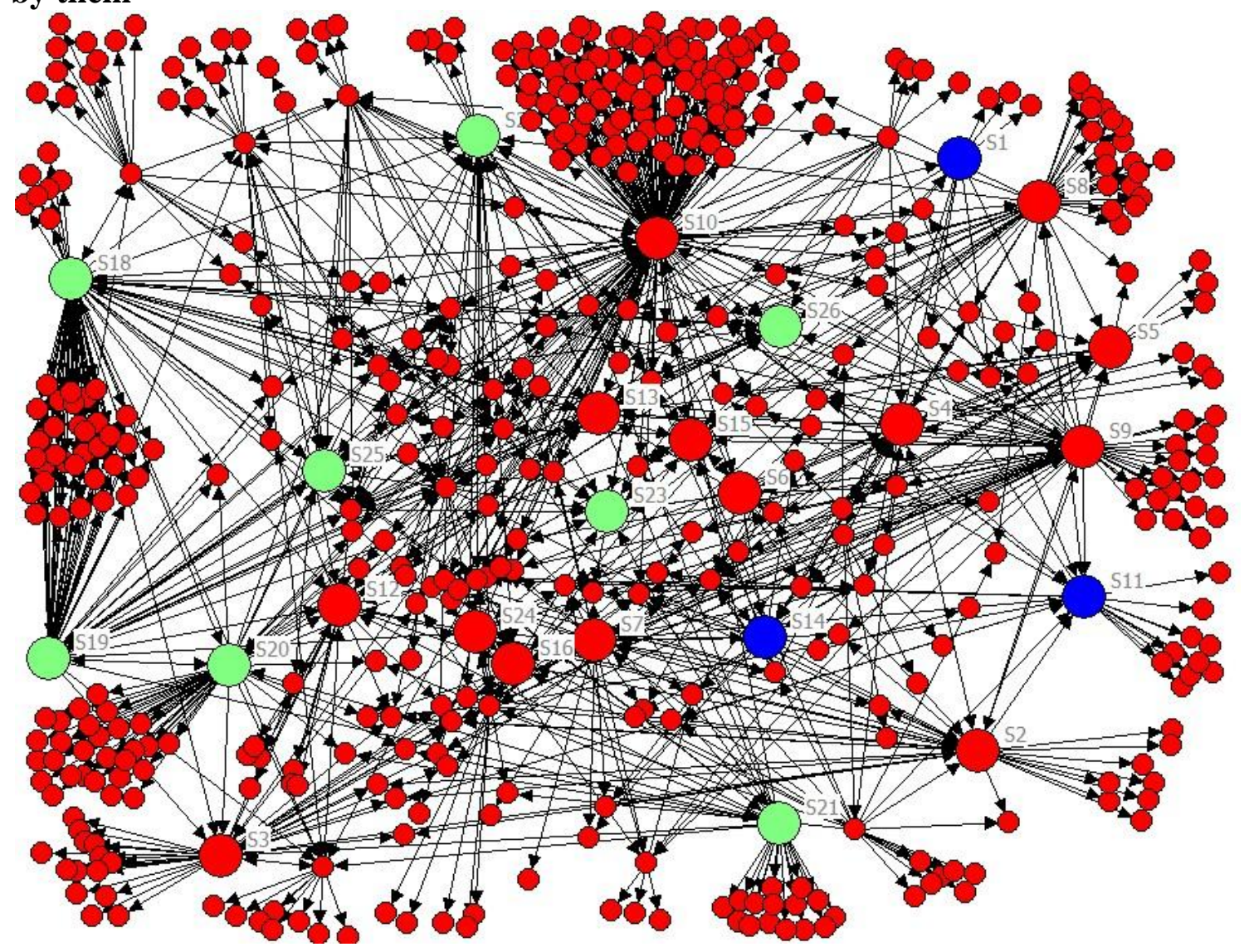

Figure 11: Network of elites, representatives (not only leaders) and named alters

Legend: •named actors, $\bullet$ central figure, $\bullet$ not central anymore, $\bullet$ became central in this network.

When employees are added to the cooperation network, the number of ties is even higher, teachers are active on daily basis in the Csángó matter and through the godfather 
program they have connections with many supporters, founders. 482 actors are present in the cooperation network with a total of 946 relations.

Focusing only on In-Degree we can see that top 3 positions are taken by MCSMSZ employees, and not any employees, all three are working in the administration of the program, are leaders of the organization or some aspects of it. S10 (17), S25 and S26 both with 14 ties, followed by four actors with 13 nominations S4, S22, S13, and S23. Originally S2 in number one position, in this network has 12 nominations, the list of ten being ended by S15 and S16 with the In-degree of 11.

\section{Network 5: Network of all named in the Csángó matter}

The following network presents the relations among all members named at least once. It is different from previous networks by containing the alter-alter relations as well. When asked whether their nominees are also working together in Csángó matters, respondents based on their subjective knowledge affirmed or denied it. Following network is the amalgamation of ego networks regarding the Csángó matter.

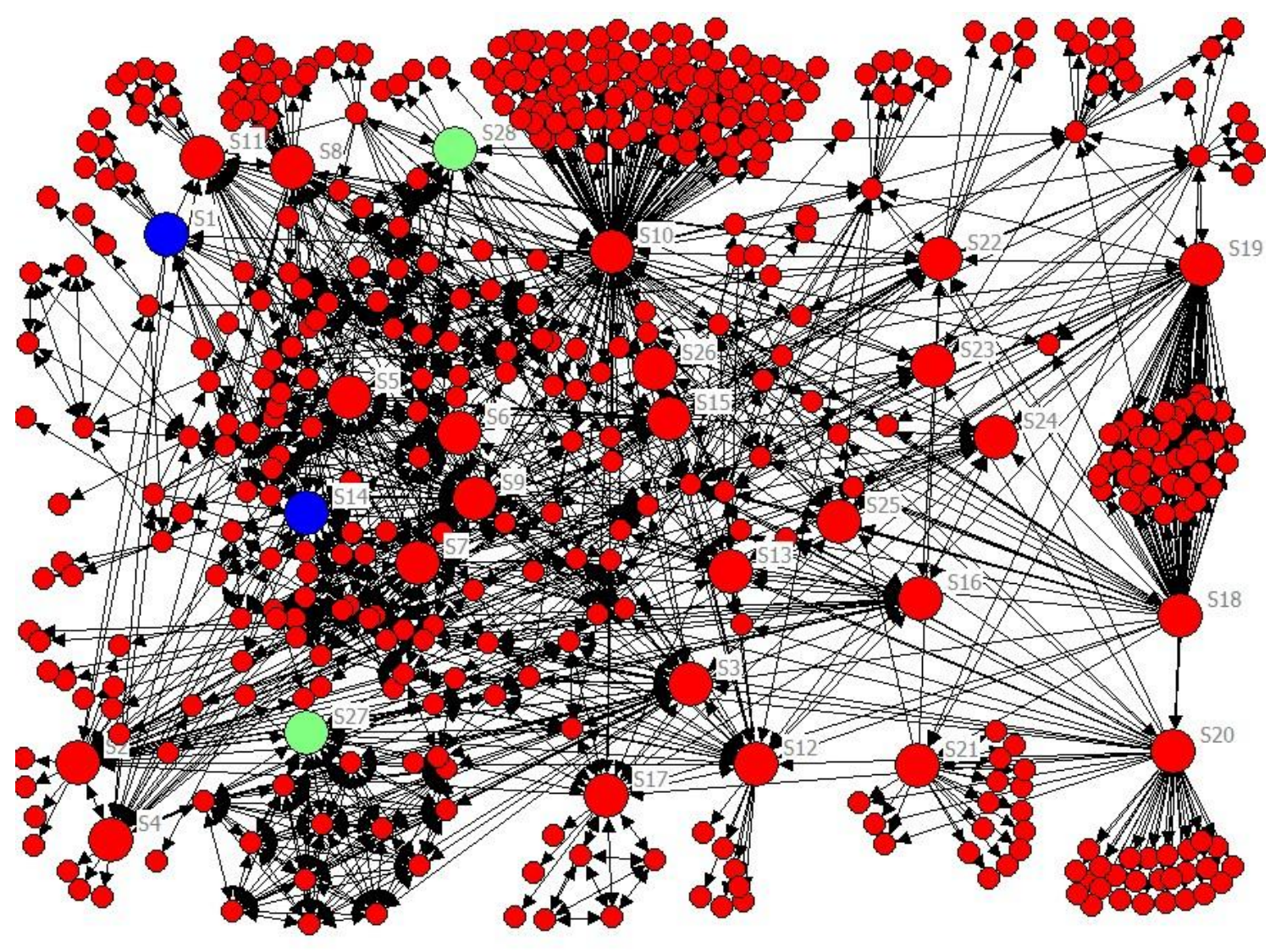

Figure 12: Network 5 Ego-alter and alter -alter relations

Legend: $\bullet$ named actors, $\bullet$ central figure, $\bullet$ not central anymore, $\bullet$ became central in this network. 
The current network contains 482 actors with a total of 1777 relations. As the total number of relations is almost double compared to the previous network, it is logic to think that basically there are two options, either completely new central persons are to appear or the centrality of previously key figures is strengthened.

Focusing similarly on In-Degree it can be seen that leading position was taken over once again, this time by a representative of an organization situated in Budapest, S9 (36). Second runner up is a teacher from Moldova S3 (32), who is highly embedded in events organized in Moldova and in Hungary as well. Key figures from Network 1 are again in leading position, S2 (26) and S5 (24). They are followed by S27, S12 and S7 with 23 nominations, S16 (22), S22 (19) and finally S17 (18).

Key actors of the network, opinion leaders and opinion brokers, have three main characteristics. First, central figures are active in several organizations and events. Those individuals, who are initiating an organization or event on their own, are likely to be central in the greater cooperation network too. Second characteristic could be, that there is a ranking among organizations and events, and it matters to be active in the most important social structures not just any organization or event. Finally, the most remarkable feature of this network is that even the Csángó elite itself considers only a few active members in relation to the Csángó matter. The number of those people who are seen as active by many others is quite low, although it is obvious that the Csángó matter involves many people and has even more supporters and sympathizers, but being very active and known as such by others restricts to only couple individuals. From the total of 482 actors according to In-Degree only 19 are those who form the top 4, later the top $10^{221}$. By looking to all other centrality measures and Egonet Broker as well, the number of central figures is still less than 30. Central actors manage to maintain their positions to a certain extent, regardless to how many new actors and relations are added to the network. Relying on the already presented brokerage typology of Fernandez and Gould (1999) brokers of the Csángó matter cooperation networks can be characterized. Reminding that the information flow is $1-->2-->3$, where the middle actor is the broker and that brockerages are members of several groups in the same time and that they can link together several groups and as such their broker roles can be of several type in the same network, cooperation networks can be characterized as it follows:

1.) Network of interviewed elites: S5 first of all is a representative (8) and almost in equally measure a coordinator (7), while S6 is a coordinator (9) and in some measure a

\footnotetext{
${ }^{221}$ For all centrality measures see Annex nr. 6
} 
gatekeeper(5). S7 primarily is a gatekeeper (19) and a consultant (15), while S2 is a representative (19) and a consultant (12) finally S4 first of all is a consultant (21) and a gatekeeper (8). S2 is the one who has high values for the coordinator, gatekeeper, representative and cunsultant categories as well.

2.) Network of elites and alters named by them: S5 is still a representative (47) yet the coordinator (40) position is also accentual, S3 is a representative while S6 maintained the role of coordinator (35). S2 while in the previous network was a representative in this network is a consultant (123), and other three types also fulfilled coordinator (17), gatekeeper (68), and representative (33). S4 maintained the consultant position (74), yet the gatekeeper (29) is also important. S4 is first of all a gatekeeper (86) and a consultant (67).

3.) Network of elites, leader representatives and alters: In this network S10, S8, S12 and S6 are enrolled to four broker types, most important being the coordinator role for S10 (781) and S6 (35), and the representative for S8 (72) and S12 (41). S2 appears as a gatekeeper (183). The consultant broker type applies the most for S9 (273), S11 (108), S3 (79) and S4(93). S7 fulfills the role of gatekeeper (74) and in equal measure the consultant (73) position as well.

4.) Network of elites, representative and alters: S10 is a coordinator (2309) and appears as a representative (310) as well. The coordinator type is most accentuated for S18 (349), S2 (183) S19 (244) and S12 (106). The broker type of S9, S7, S11 and S4 have not changed at all, the consultant position of S3 is 159 .

5.) Network of elites, representatives and alters. All named relations: by adding the alter-alter relations as well, nearly all brokers are coordinators. S10 by bringing in extra relations that are connected only through to him to the network beside the coordinator (2524) is a gatekeeper (152) and a representative (15) as well. S9 first of all is a coordinator (2092) and a representative (32), while S3 fulfills only the role of coordinator (574) broker. S8 is the only difference, being the leader of an organization in Transylvania is a consultant (403).

It can be observed that as more and more relations are added the coordinator broker position is more often. Liaison role never appears, the case when the source, the broker and the recipient belong to different groups is not typical for the csángó cooperation network. All other brokerage types appear quite often. 


\subsubsection{Organizational level}

Organizational affiliation and group membership play an important role not only in the cooperation network but in fulfilling elite positions. By shifting from individual level to the study of organizational level, focus is turned on the study of relations among the respondents - elites, representatives and employees of MCSMSZ - and organizations on one hand and events on the other hand. In order to do this a Two-Mode Network was used, where relations are directed from individuals to organizations. Persons are visualized with red, blue are the organizations and the events are with green.

\section{Network 6: Two-Mode network: relations among respondent and their organizational or event affiliation}

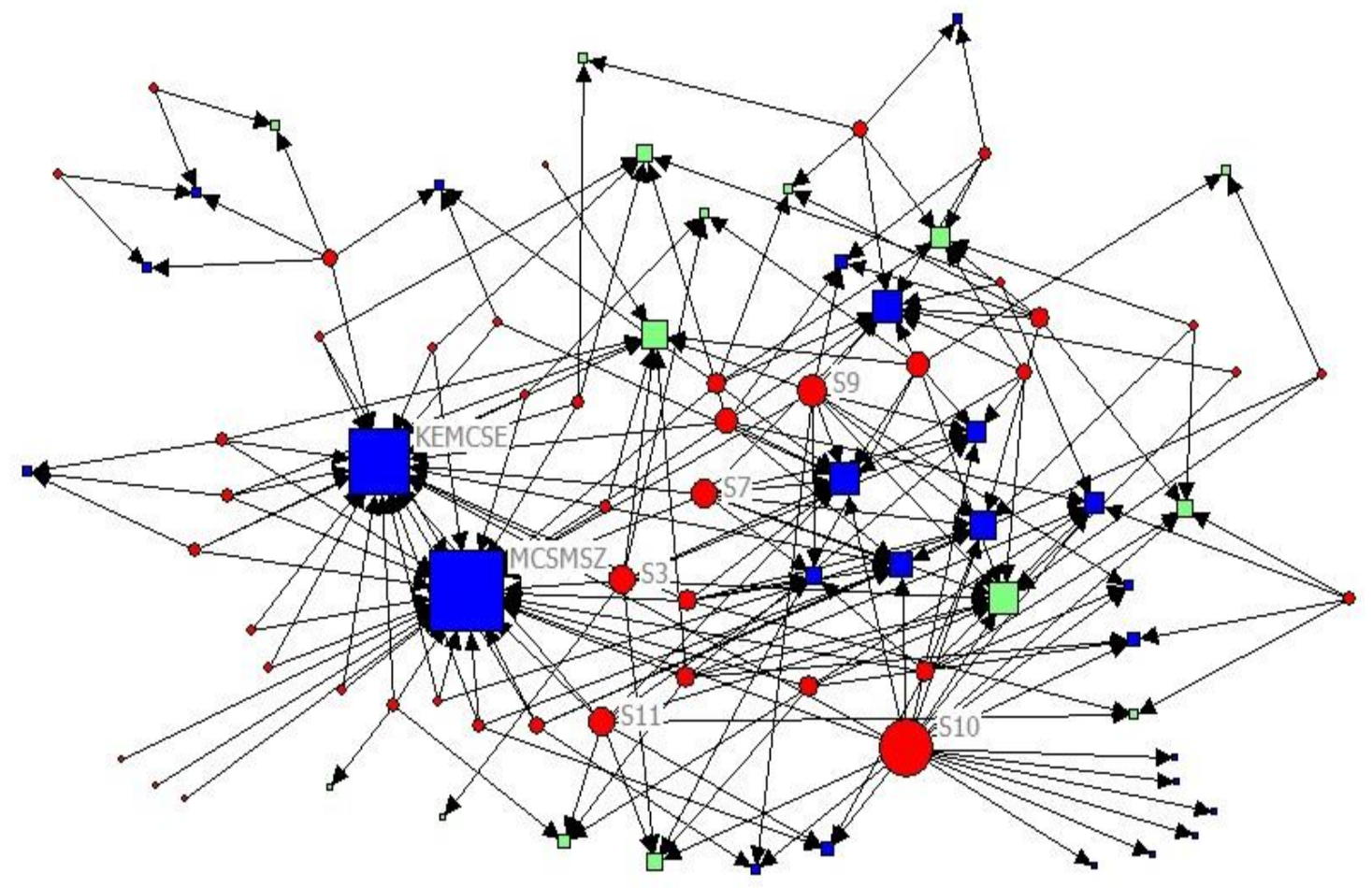

Figure 13: Network of organizational affiliation and activity in events

Legend: •named actors, $\bullet$ central figure, $\square$ organizations, $\square$ events.

Foundations and associations, the Hungarian and Romanian political sphere, and also the mass media in both countries were introduced as organizations.

It can be seen that by far the central organizations are the MCSMSZ and the background institution, KEMCSE which provides a great proportion of the material background for the Hungarian teaching. The third central group is a much more informal one, the group of young Csángós living in Budapest. One might doubt this results especially that many of the respondents are members of one of these groups, but the central position of the following two organizations - the Teleki Foundation and the less formal group of the Hungarian political sphere - underlie the results. The 
importance of the political support is shown by the fact that although no one was interviewed from the political sphere this group appears as the fifth most important in the list of named organizations.

\begin{tabular}{|l|r|l|r|}
\hline \multicolumn{2}{|c|}{ In-Degree } & \multicolumn{2}{c|}{ Betweenness } \\
\hline MCSMSZ & $\mathbf{2 9}$ & MCSMSZ & $\mathbf{1 0 0 8 . 3 6 5}$ \\
\hline KEMCSE & $\mathbf{2 3}$ & KEMCSE & $\mathbf{8 8 2 . 9 6 9}$ \\
\hline Friends of Csángós for Csángós & $\mathbf{1 1}$ & $\begin{array}{l}\text { Friends of Csángós for } \\
\text { Csángós }\end{array}$ & $\mathbf{2 8 1 . 8 6 5}$ \\
\hline Teleki Foundation & $\mathbf{1 1}$ & Teleki Foundation & $\mathbf{1 7 3 . 3 8 6}$ \\
\hline Hungarian Political Sphere & $\mathbf{9}$ & Hungarian Political Sphere & $\mathbf{1 2 9 . 8 2 0}$ \\
\hline AMMOA & 8 & Szeret-Klézse Foundation & 90.199 \\
\hline Szeret-Klézse Foundation & 7 & Episcopie of Iaşi & 81.333 \\
\hline Pro-Minoritate & 7 & AMMOA & 80.543 \\
\hline Foundation for the house of & 5 & Pro-Minoritate & 59.890 \\
Pusztina & & & 43.157 \\
\hline Főnix Foundation & 4 & Archdiocese of Esztergom & 39.833 \\
\hline Universities from Romania & 4 & Association of Dumitru & \\
\hline Foundation of Lakatos Demeter & 4 & Foundation of Lakatos Demeter & 38.071 \\
\hline Hungarian Red-Cross & 3 & Főnix Foundation & 24.633 \\
\hline DomokosPálPéter Foundation & 3 & Universities from Romania & 12.944 \\
\hline Episcopate of Iaşi & 3 & Foundation for the house of & 12.569 \\
& & Pusztina & \\
\hline Archdiocese of Esztergom & 3 & Romanian Political Sphere & 7.798 \\
\hline Romanian Political Sphere & 3 & Domokos Pál Péter Foundation & 7.748 \\
\hline Malthese Charity Service & 2 & Malthese Charity Service & 1.063 \\
\hline Association of Dumitru Martinas & 2 & Hungarian Red-Cross & 0.750 \\
\hline Pedagógia Egyesület & 1 & Pedagógia Egyesület & 0.000 \\
\hline Hungarian Academy of Science & 1 & Hungarian Academy of Science & 0.000 \\
\hline Universities from Hungary & 1 & Universities from Hungary & 0.000 \\
\hline Hungarian Media & 1 & Hungarian Media & 0.000 \\
\hline Romanian Media & 1 & Romanian Media & 0.000 \\
\hline Siret Cultural Foundation & 1 & Siret Cultural Foundation & 0.000 \\
\hline
\end{tabular}

Table 7: Centrality measures of organizations, foundations and interest groups

Just like in the case of organizations when speaking about events, first positions are mostly occupied by actors connected to Hungary. While in the case of organizations only the MCSMSZ is geographically situated in Moldova, in the top five of events we can see the Csángó Ball, organized yearly in Budapest and the Táncház which is also specific to Hungary, yet named by several MCSMSZ employees too. The third position is taken by the journal, published by Csángós living in Budapest, the Csángó Tükör (Csángó Mirror), followed by another journal, published in Széklerland, the Moldvai Magyarság (Hungarians from Moldova) and the Csángó festival organized in Jászberény, Hungary. 
By now it is clear that by events several things can be understood, such as publications, balls, tourism, exhibitions, conferences and other cultural aspects. Probably if it would have been mentioned Hungarian teaching - the most important event of the Csángó matter, with the greatest financial support - would end up at number one position, but since respondent did not name it, it is missing from the list. Although by being linked to MCSMSZ, means being linked to the Hungarian teaching in Moldova.

\begin{tabular}{|l|r|l|r|}
\hline \multicolumn{2}{|c|}{ In-Degree } & \multicolumn{2}{c|}{ Betweenness } \\
\hline Csángó Ball & $\mathbf{1 1}$ & Csángó Ball & $\mathbf{1 9 5 . 0 3 5}$ \\
\hline Táncház & $\mathbf{9}$ & Táncház & $\mathbf{1 4 2 . 2 4 5}$ \\
\hline CsángóTükör Journal & $\mathbf{6}$ & MoldvaiMagyarság Journal & $\mathbf{6 1 . 8 1 7}$ \\
\hline MoldvaiMagyarság Journal & $\mathbf{5}$ & CsángóTükör Journal & $\mathbf{5 4 . 9 0 3}$ \\
\hline $\begin{array}{l}\text { Csángó festival from } \\
\text { Jászberény }\end{array}$ & $\mathbf{5}$ & Romanian masses in Hungary & $\mathbf{3 9 . 8 3 3}$ \\
\hline Trips to children & & & \\
\hline Folk song competition & 5 & Csángó festival from Jászberény & 32.756 \\
\hline Village days of Magyarfalu & 4 & Trips to children & 23.548 \\
\hline Village week of Somoska & 3 & Cheer, catering & 14.028 \\
\hline Cheer, catering & 3 & Village days Magyarfalu & 13.544 \\
\hline Romanian masses in Hungary & 3 & Broadcasting on Radio Ciucani & 12.904 \\
\hline Exhibitions & 2 & Folk song competition & 11.157 \\
\hline Broadcasting on Radio Ciucani & 2 & Village week of Somoska & 7.739 \\
\hline Choir & 2 & Exhibitions & 2.553 \\
\hline farewell & 1 & Choir & 0.000 \\
\hline
\end{tabular}

Table 8: Centrality measures of events

\subsubsection{Regions/country level}

Before turning to the regional, national aspects of the cooperation relations regarding the Csángó matter it needs to be admitted, that strictly taken relations are still at individual level. What can be seen as relation among regions, is more the relation among the individuals from specific regions. So far the cooperation network was analyzed by researching the central actors of it, regardless of their identity or geographic location. In the following part these two attributes are added to the network.

As it concerns geographic location following categories were used: Moldova, other regions of Romania mostly Transylvania and Bucharest, and as a third category Hungary. A fourth category was included for those alters who are not living in neither Hungary nor Romania, while fifth category stands for those whose geographic location was uncertain or not known. In order to avoid any misunderstanding and to not offend anyone in the case of the second attribute, namely whether these members are Csángó or not, everyone who was born in Moldova and is Catholic is considered Csángó. 
Network 7. Network of all named in the Csángó matter by location

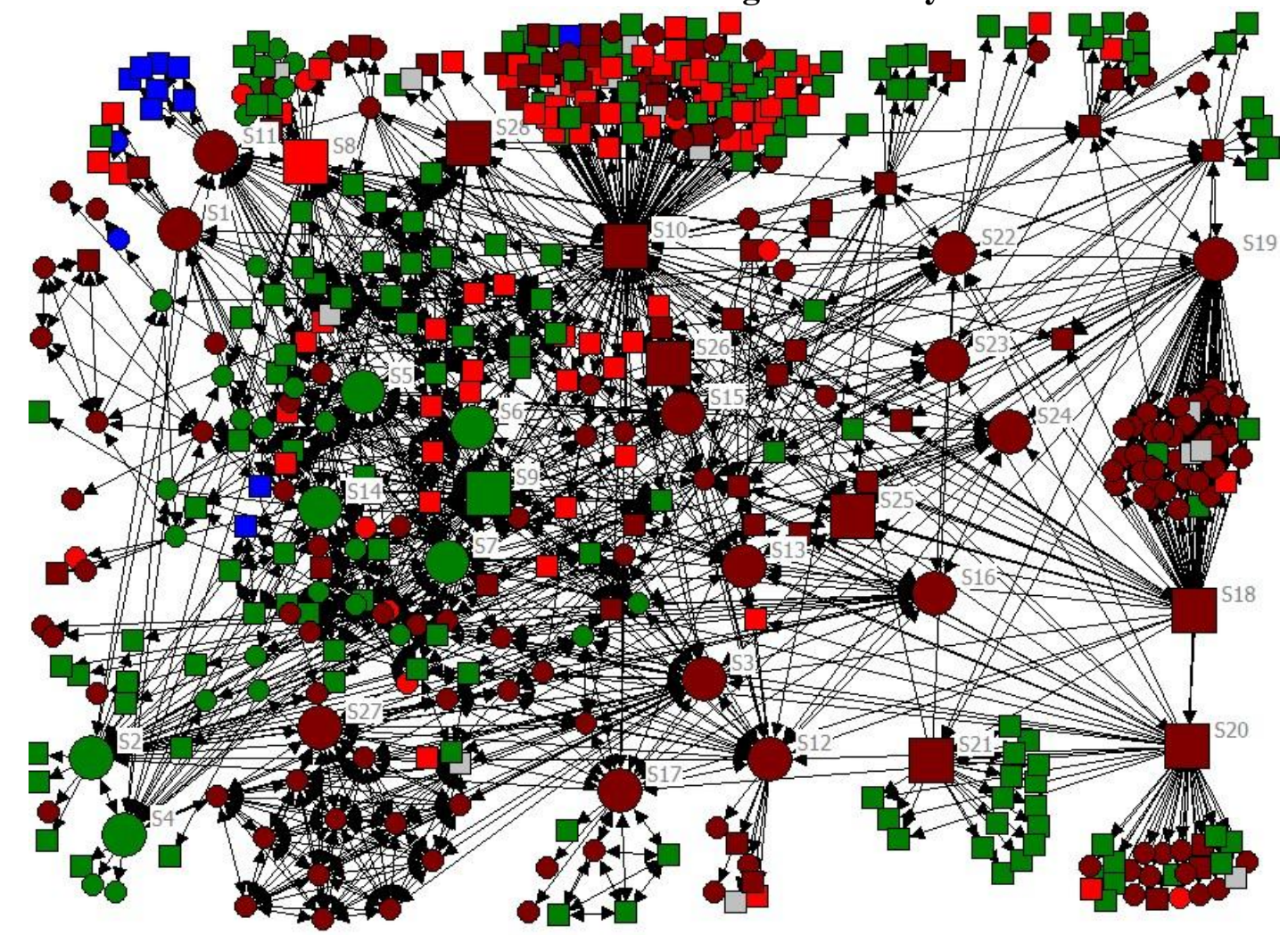

Figure 14: Network of all named in the Csángó matter by location and by being Csángó or not Legend: $\bullet$ Moldova, $\bullet$ Romania but Moldova, $\bullet$ Hungary, $\bullet$ Other, $\bigcirc$ No data; $\bigcirc$ Csángó, $\square$ Not Csángó.

\begin{tabular}{|l|r|l|r|r|r|r|}
\hline & Moldova & $\begin{array}{l}\text { Romania } \\
\text { (but Moldova) }\end{array}$ & Hungary & Other & \multicolumn{1}{l}{$\begin{array}{l}\text { No } \\
\text { Data }\end{array}$} & \multicolumn{1}{l|}{ Total } \\
\hline Csángó & 134 & 9 & 31 & 2 & 0 & $\mathbf{1 7 6}$ \\
& $27,8 \%$ & $1,8 \%$ & $6,4 \%$ & $0,4 \%$ & $0 \%$ & $\mathbf{3 6 , 5 \%}$ \\
\hline Not Csángó & 54 & 71 & 156 & 11 & 14 & $\mathbf{3 0 5}$ \\
& $11,2 \%$ & $14,7 \%$ & $32,4 \%$ & $2,3 \%$ & $2,9 \%$ & $\mathbf{6 3 , 3 \%}$ \\
\hline Total & $\mathbf{1 8 8}$ & $\mathbf{8 0}$ & $\mathbf{1 8 6}$ & $\mathbf{1 3}$ & $\mathbf{1 4}$ & $\mathbf{4 8 2}$ \\
& $\mathbf{3 9 \%}$ & $\mathbf{1 6 , 6 \%}$ & $\mathbf{3 8 , 6 \%}$ & $\mathbf{2 , 7 \%}$ & $\mathbf{2 , 9 \%}$ & $\mathbf{1 0 0 \%}$ \\
\hline
\end{tabular}

Table 9: Distribution of respondents based on geographic location and being Csángó or not.

The proportion of those who are living in Moldova and those who are in Hungary is almost the same in the cooperation network. The network is not divided along geographic regions; there are many relations that link together Moldova, other parts of Romania and Hungary. Elites and leaders of organizations play a high role in linking together regions, regardless where they are living. Yet it can be said that those living in Hungary seem to name more people from Hungary and those from Moldova are more connected with locals from Moldova. Good exceptions are S2 or S3 who are members of dense networks in Moldova and in Hungary as well, which is interesting especially 
that S2 lives in Hungary while S3 lives in Moldova. It is possible to be active on both locations regardless of the place of residence.

Including several members of the MCSMSZ in the cooperation network obviously the number of relations showing to - or from Moldova is higher (basically we have many burgundy dots with lots of connections). The representatives - S8, S9, S10 - of three major organizations have the most heterogeneous network as it concerns the geographic location of their alters. At this point is clear that many alters connected to the Csángó matter - most of them supporters, upholders - are living in Hungary. Alters from Moldova who are similarly linked (only through one person) to the Csángó matter are usually local people, who are occasionally involved to some events, by the teacher of the MCSMSZ. During interviews these relations were often named as "the village".

Not only elites and representatives are in central position, but teachers as well, who are active in several aspects of the Csángó matter and connect many supporters to it. Along teaching, they organize different events in the villages, and often manage to bring their own personal network in relation with the Csángó matter. As such they are connected with foreign supporters and local people as well. (ex. S18, S19, S20, S21)

\subsubsection{Maintaining central position as actors and relations are added}

After seeing who are the central actors in each network the focus is turned on how they have changed their position. Using line diagram for the calculated centrality measures made possible to visualize the position of each central actor along the five networks. To the network of interviewed elites (Network1) their alters were added (Network 2) then representatives with their alters (Network 3) were included too, only to be followed by employees of the MCSMSZ and their nominees (Network 4), to finish with a whole network, including all relations. (Network 5).

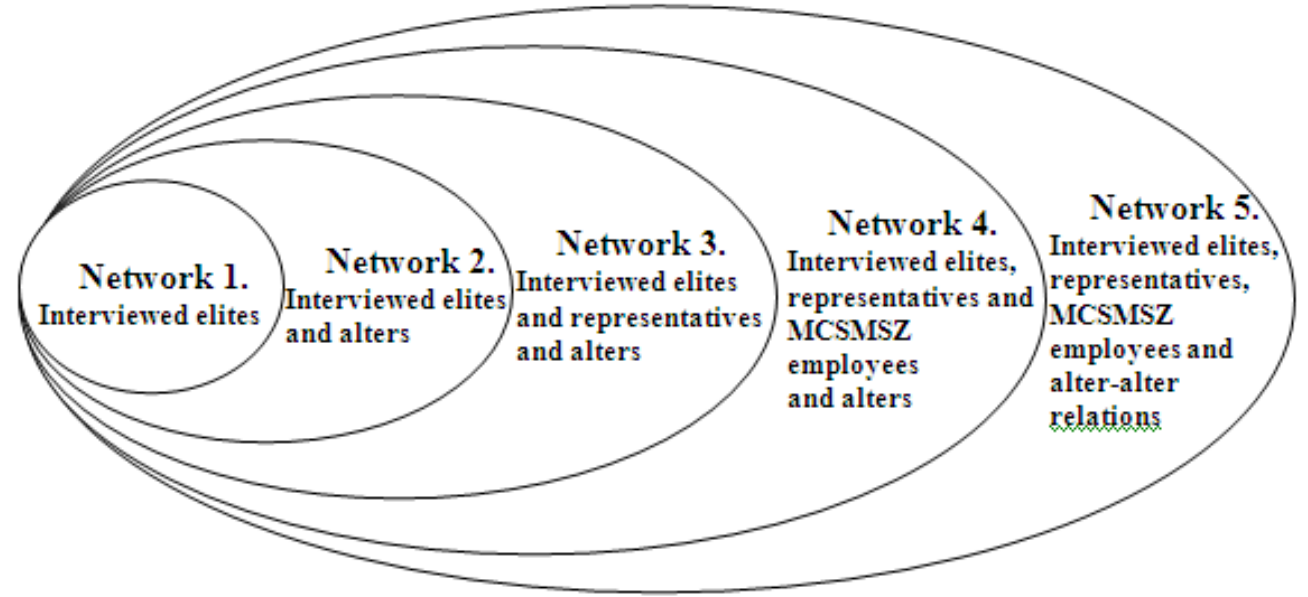




\subsubsection{Central positions at different levels of the network based on Degree}

The following diagram is drawn based on the Degree ranking from 1 to 10 . Using the actual values would have been difficult because S10 has a degree of nearly 180 while the rest of the central actors have much lower values.

In total there were 15 people selected as central figures, in the first two networks having only couple relations only the first four were selected as centrals, later by increasing the number of egos and alters always the top 10 was included.

\section{Central positions at different levels of the network based on Degree}

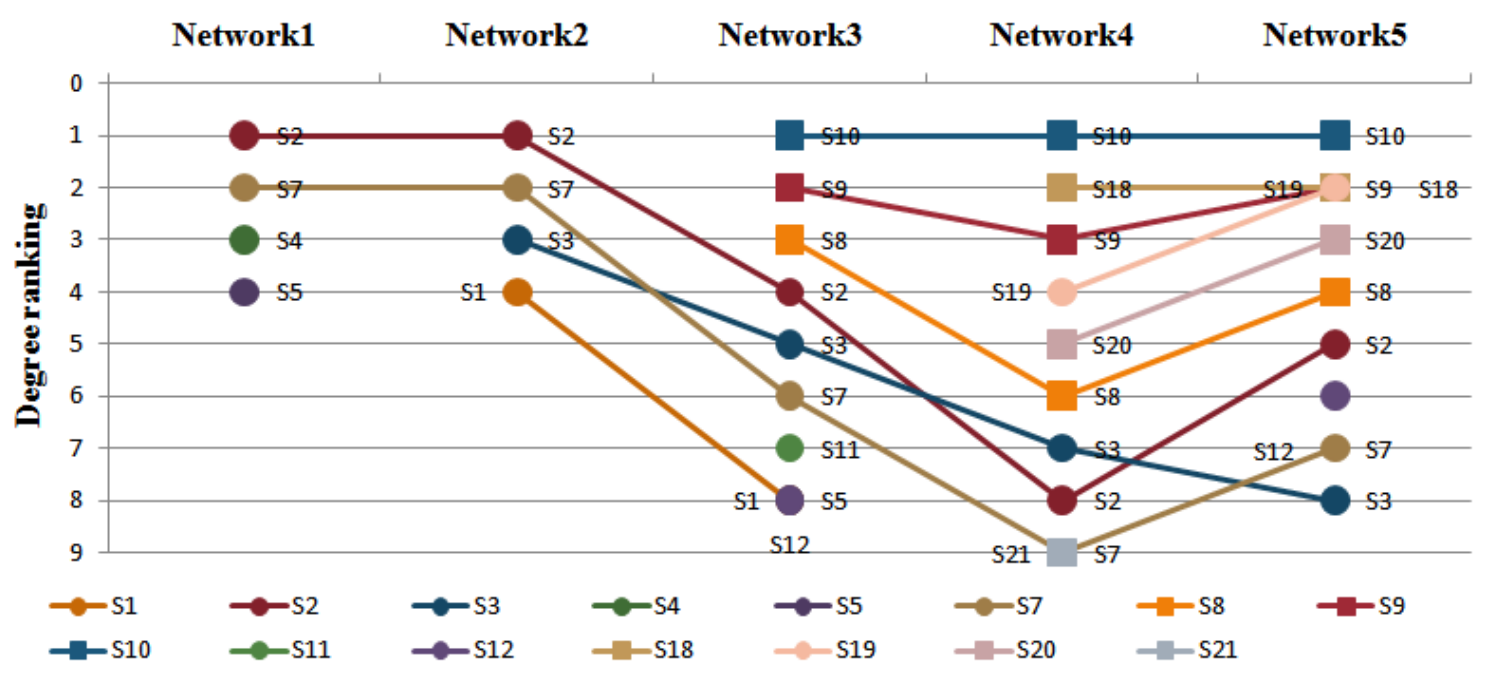

Figure 15: Central positions at different levels of the network based on Degree

Legend: OCsángó, $\square$ Not Csángó.

Following characteristics can be seen:

1. From the total of 15 people 9 are Csángós and 6 are non-Csángó.

2. As soon as S10 was introduced, the first place is permanently occupied by him, regardless of the size of the network. It is important to mention that this is so because there are many alters that are connected to the Csángó matter only through him and since degree includes relations showing not only to but also from a specific actor, having the highest out-degree put's him on the first position.

3. We can see that S2 and S7 manage to maintain their central position all along. They are both Csángós living in Budapest, named as elites and active in several organizations and events.

4. S3 - a teacher in Moldova and member of the Csángó elite - is central in all networks except the first one. S3 is a good example on how one can be active in Moldova and in Budapest as well. 
5. Beside S10 other two organizations were represented - by S8 from Transylvania and S9 from Hungary - and from their introduction they are among the central actors.

\subsubsection{Central positions at different levels of the network based on In- Degree}

By knowing that collecting relational data from all actors involved in the Csángó matter and seeing how out-degree influences one's centrality focus is turned to a measurement that has a higher confidence, as Costenbader and Valente pointed out. (Costenbader \& Valente, 2003)

\section{Central positions at different levels of the network based on In-Degree}

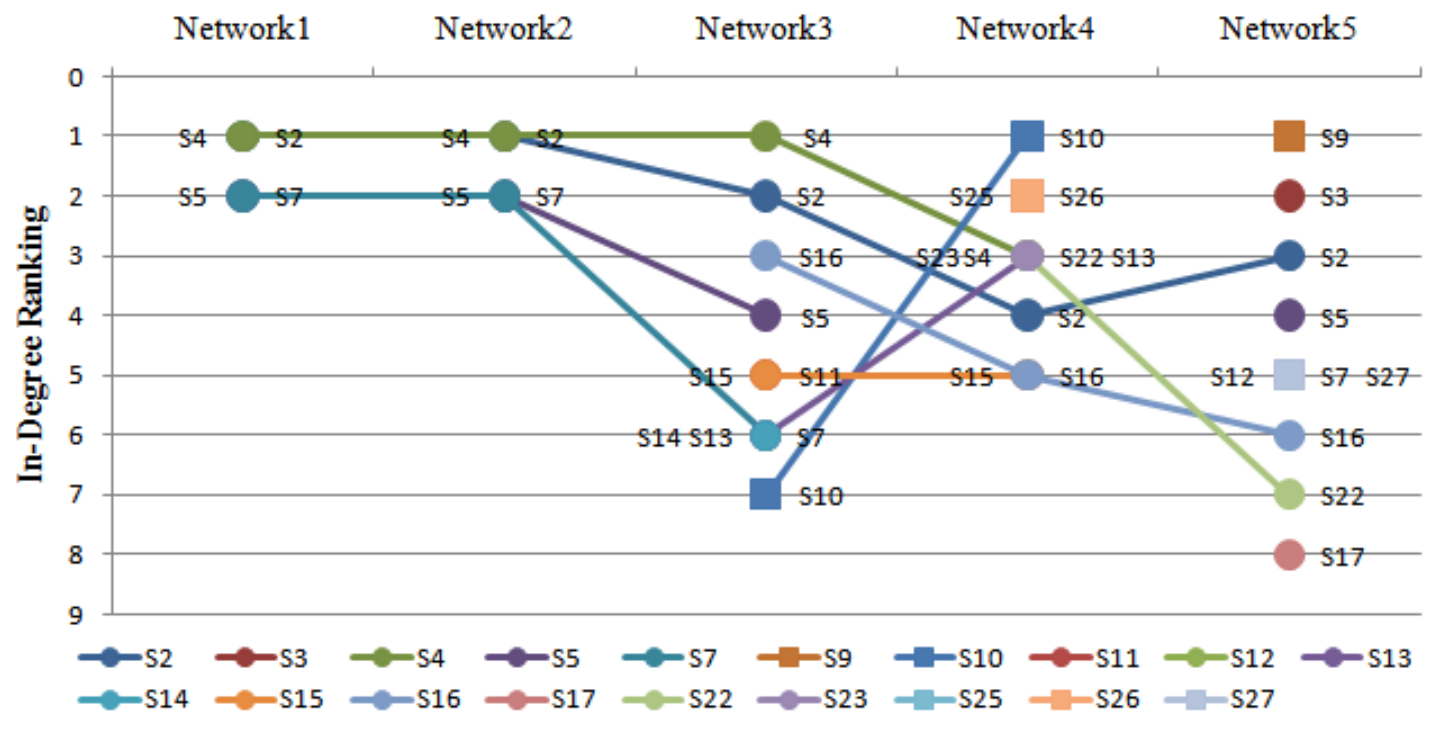

Figure 16: Maintaining central position in networks according to In-degree

Legend: OCsángó, $\square$ Not Csángó.

Just as previously in the first two networks the four actors with the highest indegree were included, later by increasing the number of actors focus was turned to the top 10 in each network. The total number of central actors is of 19 people. Following the positions of these people all along the five networks three observations can be made.

1. 15 are Csángó and 4 are non Csángó. From these four 3 are working at the MCSMSZ office, and one is the representative of an organization from Hungary.

2. Highest In-degrees - comparing all networks - are held by S10, S25 and S26, all three key figures of the MCSMSZ office. Being in a leading position at the MCSMSZ ensures one's centrality.

3. S2 manages to maintain the central position, being probably the only member of the Csángó elite who is always in key position. S4 is central until Network 4, in the last 
network is at position $11^{\text {th }}$, so basically also managed to keep centrality. It is important to mention though that they are both living in Budapest so there is a possibility that geographic location has an influence on one's centrality. This and similar suppositions shall be tested with regression analysis.

\subsubsection{Central positions at different levels of the network based on Betweenness}

Betweenness was the third centrality measurement used to analyze ones network position and the role of participant in the Csángó matter. At the base of this measurement stands the supposition that an actor is successful in a network due to his intermediate role among two groups. (Letenyei, 2005) The top 5 were introduced in the first two networks and top 10 in the wider networks. While in previous cases in the first two networks four actors were introduced, here there are five, simply because as it can be seen in both networks we are dealing with the same actors only in different order, so it is more accurate to have under focus these actors from the beginning.

Based on Betweenness 17 actors were selected as central in one or several networks.

\section{Central positions at different levels of the network based on Betweenness}

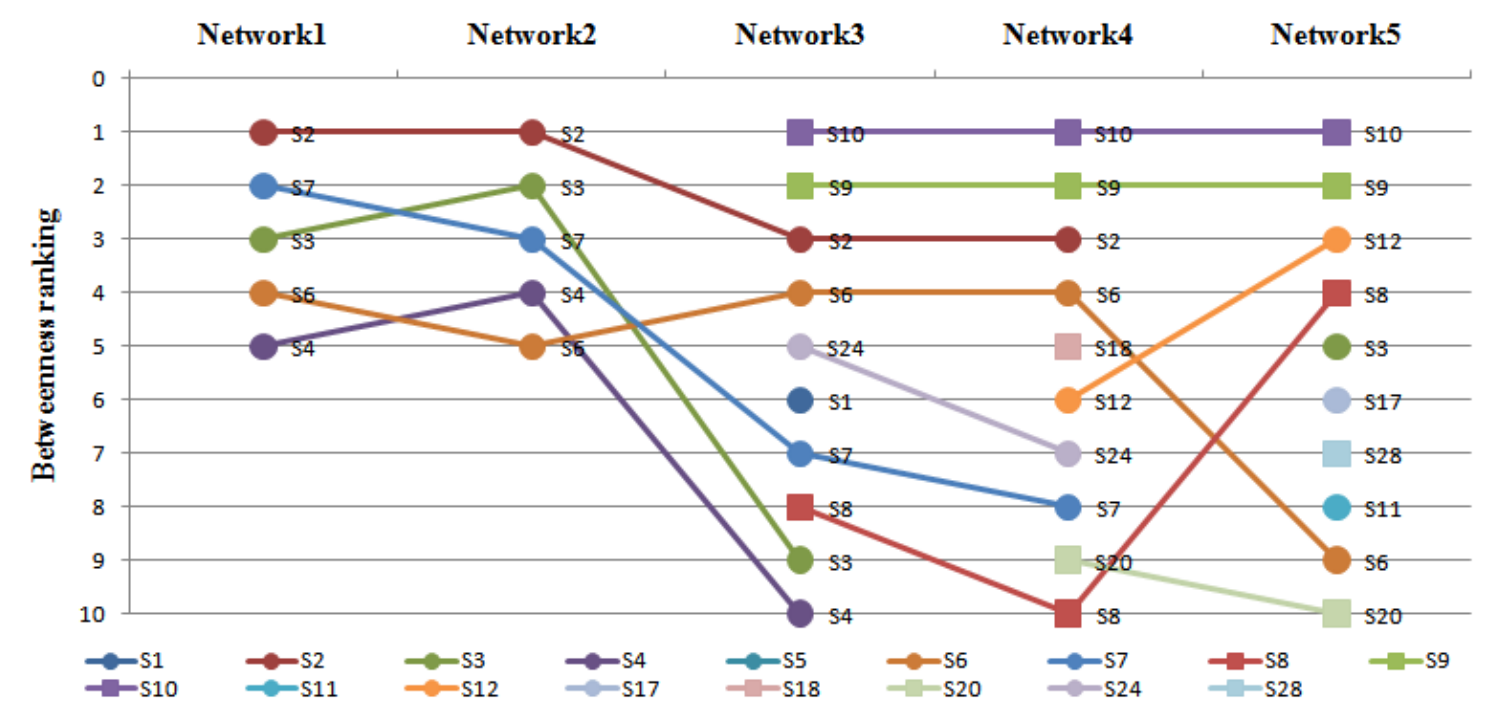

Figure 17: Maintaining central position in networks according to Betweeness

Legend: OCsángó, $\square$ Not Csángó.

Due to the betweenness values, calculated with three decimals, there aren't any coinciding cases.

1. From the total of 17 actors 11 are Csángós and 6 are non-Csángós, it seems that when it comes to intermediating positions the proportion of non-Csángós is slightly higher. 
2. Probably the strongest position is of S10 and S9. Just as previously number 1 position in ranking is occupied by $\mathrm{S} 10$, followed by $\mathrm{S}$.

3. S6, a Csángó priest living in Hungary, who was also named as elite, is fulfilling the intermediate role in all networks. He is in good terms with the MCSMSZ and the Csángós from Hungary as well. He is the only who fulfills the intermediate role in all five networks.

4. S2 and S3 are present in four out of five networks.

Based on the three diagrams and interviews an option palette can be formulated on how one can have central position in the Csángó matter. In-Degree proved that being in a leading position at the MCSMSZ ensures high centrality. Being active in only one region does not seem enough; one has to participate in events and organizational work in Moldova and Hungary as well. For those living in Hungary involvement in events organized in Moldova is even more important otherwise they will be exclusively named only by others from Hungary. Activity cannot be restrained to only one event or one organization. Bringing in social capital under the form of alters connected to the Csángó matter only to one actor, ensures him/her central position. Being elite helps, but only if it is correlating with high activity in several events. Fulfilling the role of opinion leader or broker, bridging regions or groups is of high benefits.

\subsubsection{Network case studies}

By introducing the representatives to the Cooperation network of the Csángó matter the size of social capital suddenly increased due to the high out-degree of these respondents. In order to see whether there are any outliers, as it concerns the number of relations following diagram was drawn, which presents the distribution of Degree, containing all relations that show to and from a specific person.

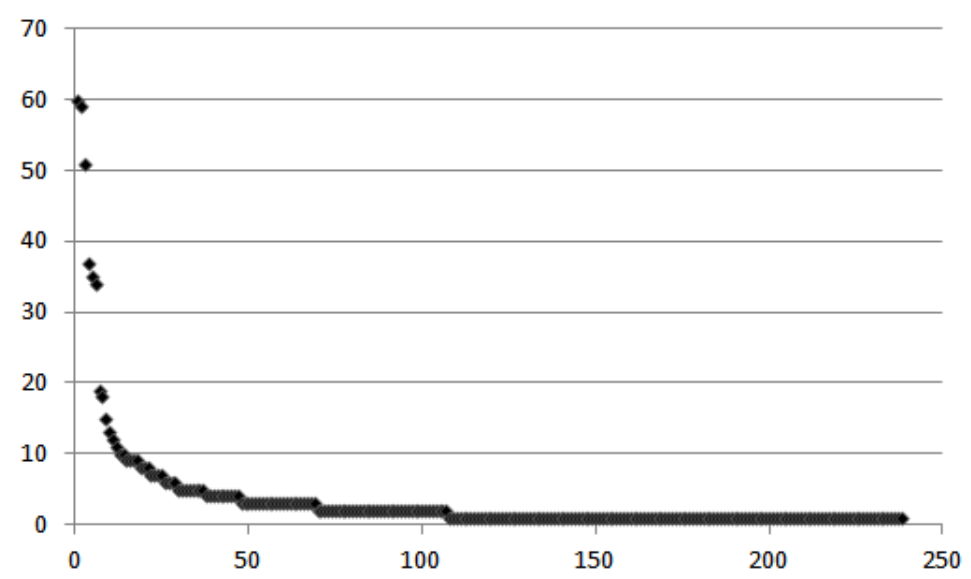

Figure 18: Distribution of nominations based on respect, prestige 
Ronald S. Burt writes about the Hole Processes that it takes only the first some individuals to link together groups, and the value of linking disappears much sooner that all eligible actors might utilize it; "the first few bridges suffice". (Burt, 2001:230)

\subsubsection{Most important groups}

Using all relations mentioned - ego-alter and alter-alter as well - the cooperation network was analyzed in chapter 5.1.2. where focus was on the importance and differences of regions. The network was transformed in a way to present the most obvious - through dense ego-networks - groups of people. By this, in a manner, we return to the organizational level of the network analyzes, only that now instead of focusing on organization affiliation or organization of certain events the goal is to delimit groups based on the structure of the whole network.

First of all the network was drawn based on ordination/scaling of tie variables, then all actors were sized based on their In-degree.

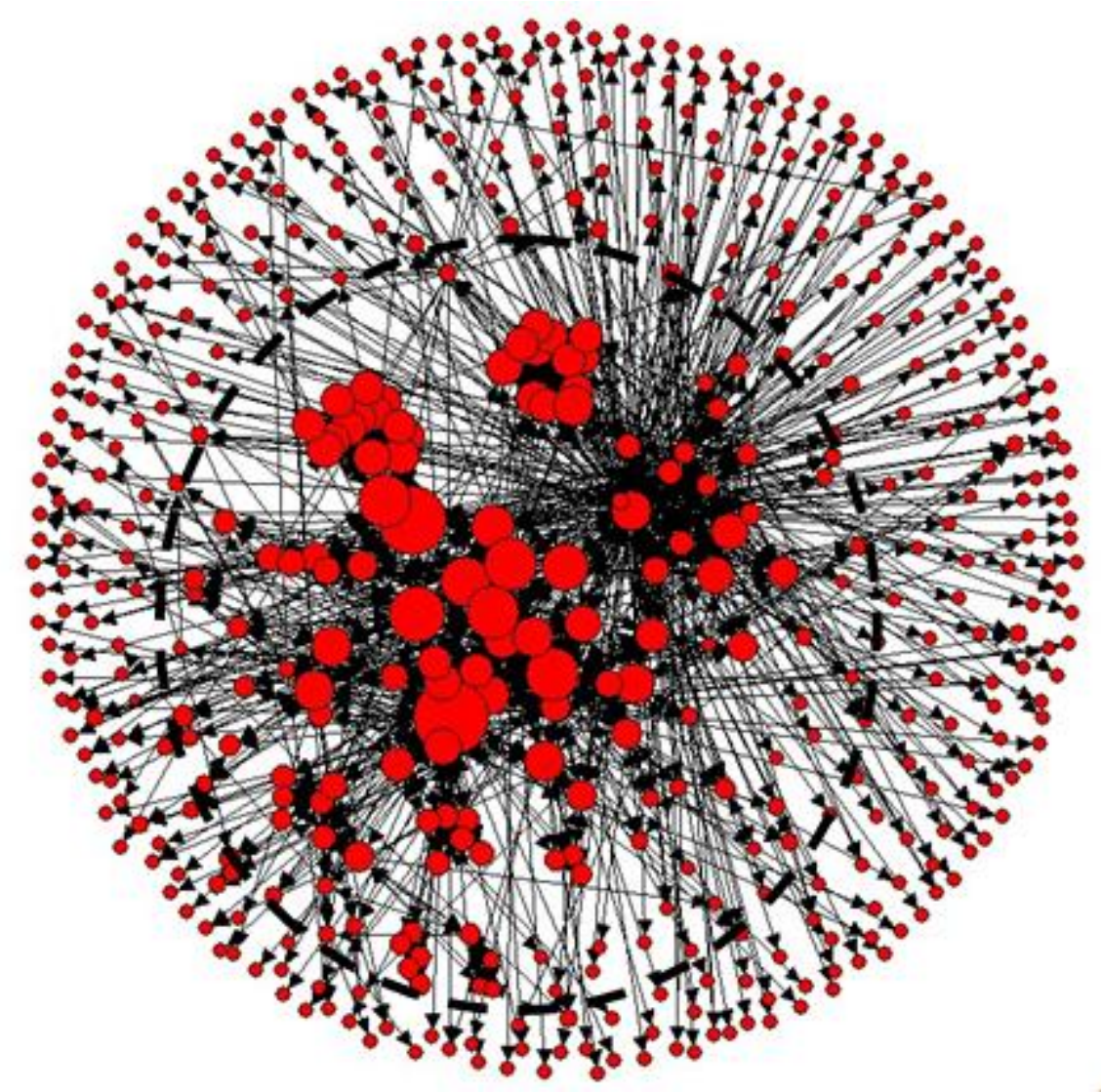

Figure 19: Network of most important groups formed by personal relations

By looking at the network above some groups can be easily defined. In order to see someone as a group member that person should be named by at least four people, as such those actors whose In-degree is lower or equal with 3 were dropped. In order to 
have a better insight on these groups, all group members were visualized with the same size dots and as such the following network is received:

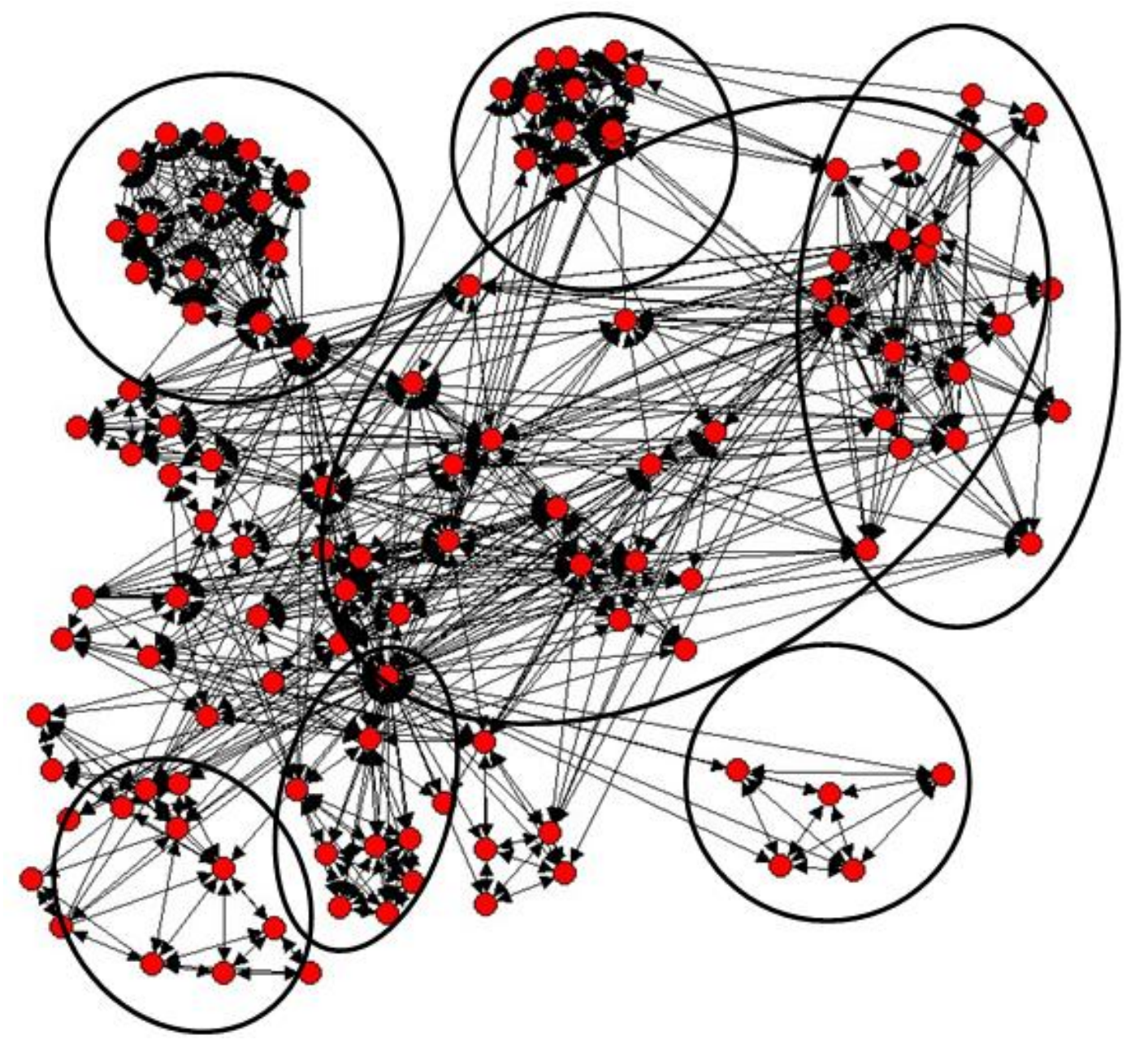

Figure 20: Most important groups

The same groups that were named in the discussion of the organizational level of the cooperation network can be observed here too. This network clearly shows that on one hand there are some actors who are members of several groups of people, on the other hand that beside the high density, members of a group of an organization are highly connected.

In the following part two very well defined groups and their networks shall be presented. Seeing the differences underlined by interviews among Csángós in Hungary and several members of the MCSMSZ, the two networks are of those members who are working at the MCSMSZ and of those who are seen as the opposition, the "Csángós from Budapest". The goal is to see the characteristics of the two networks, to see if there are common members and to check if by taking away one - no matter which - part of the whole network from the Csángó matter it suffers a great loss of social capital or not. Are the relations accumulated in a higher proportion by any of these two groups? 
Following networks were created by using the Ego-Alter relations only. All networks analyzed from now on, are presenting hypothetical cases, and conclusions are true and should be seen as valid only in network aspects.

\subsubsection{Network of MCSMSZ}

The following network is drawn by using only the data received from the members of the MCSMSZ, after which by excluding the teachers, the network will be constrained only on the relations sustained by those who work in the office, the leaders of the organization.

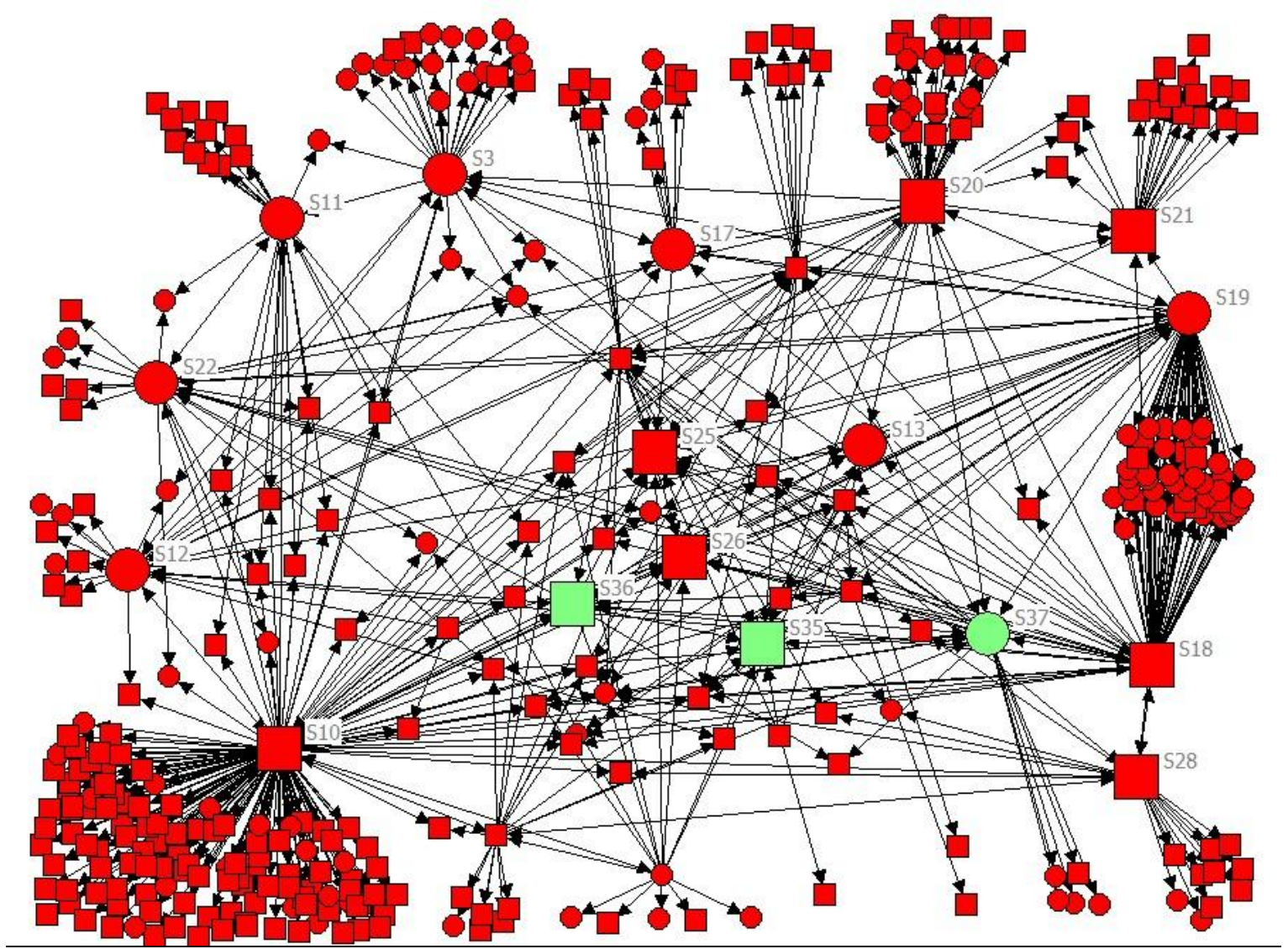

Figure 21: Network of the MCSMSZ members

Legend: •named actors, $\bullet$ central figure, $\bigcirc$ became central in this network. OCsángó, $\square$ Not Csángó.

The total number of relations is 617 , and it can be observed that by restricting the network to the nominations of the MCSMSZ, other people-S35, S36 and S37 - manage to appear among central actors. All three are working in the MCSMSZ office, one of them is Csángó who studied in Hungary and after Graduation returned to Moldova, he was also named as Csángó elite. New central actors are all working in the administration of the MCSMSZ and interviews underlie that the conflict situation is between the MCSMSZ office and Csángós from Hungary. These are the two reasons that lead to the following network. 


\subsubsection{Network of MCSMSZ office}

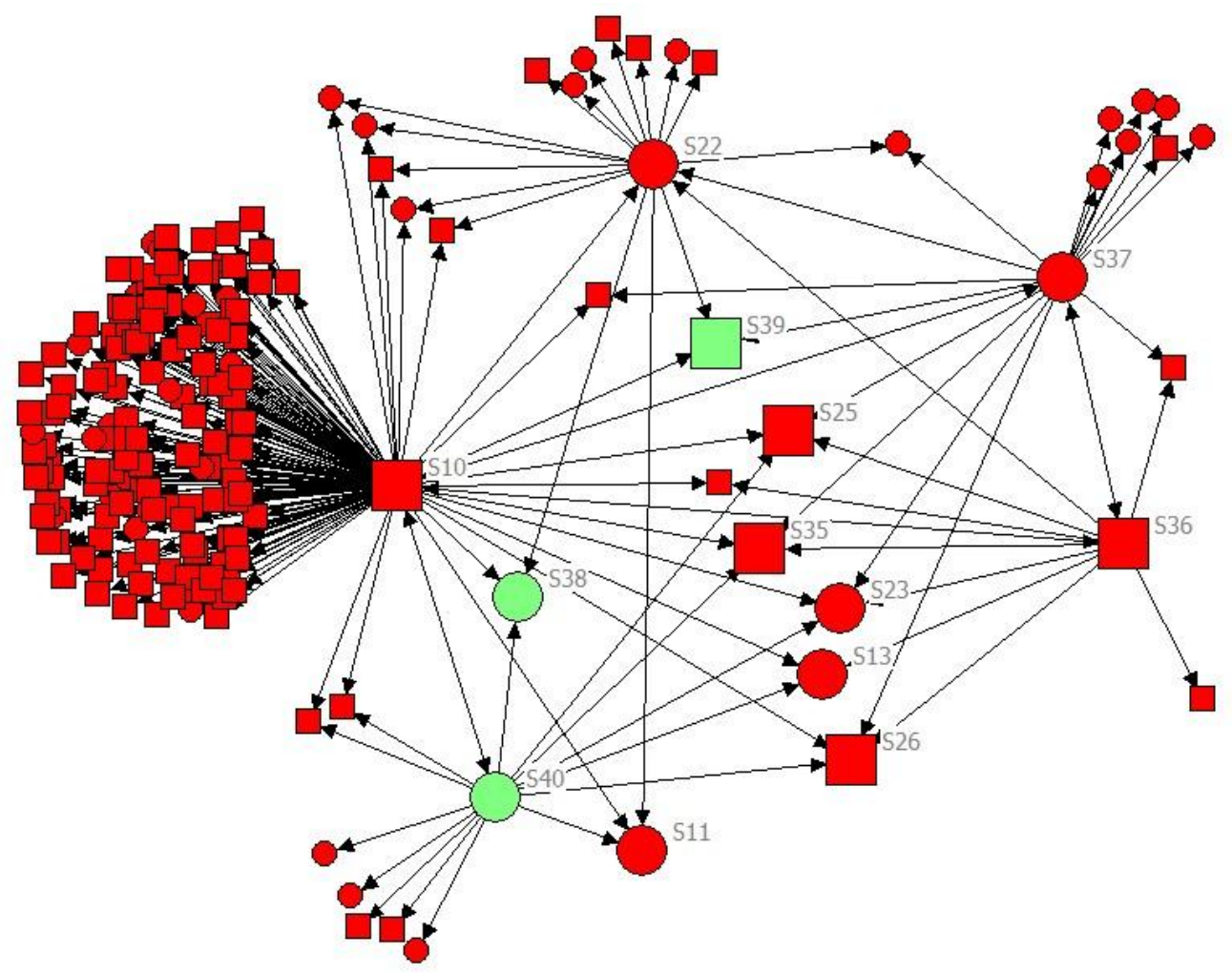

Figure 22: Cooperation network of MCSMSZ office employees

Legend: •named actors, $\bullet$ central figure, $\bigcirc$ became central in this network. OCsángó, $\square$ Not Csángó.

After including in the cooperation network only those relations that belong to the MCSMSZ office employees, the total number of relations is only 230, from which nearly half are the nomination of S10. The conclusion so far is that by excluding the teachers and those active members who are living in Hungary, the Csángó matter - in network aspects - suffers a significant loss. If all members would have been interviewed probably much more alters would have been included in the network, yet it is likely that most frequent and important relations are already present. From the three newly central actors S38 and S40 were named as Csángó elites.

\subsubsection{Network of Barátikör}

What changes if the Csángó matter would be represented only by the Barátikör, the Csángós from Budapest is the question to be answered next. Following network is drawn by using only the data received from the members of the Barátikör. 


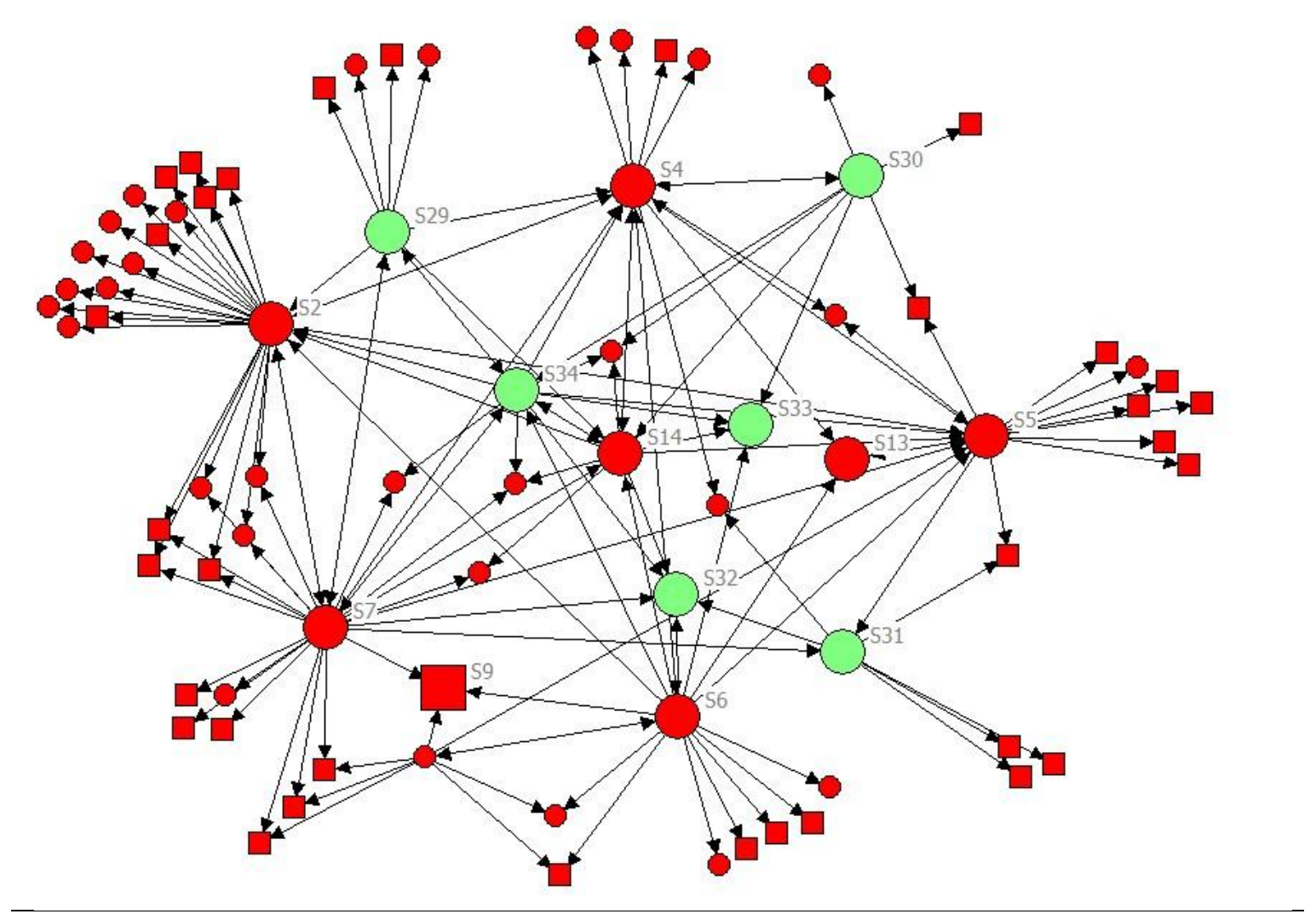

Figure 23: Network of Barátikör

Legend: •named actors, $\bullet$ central figure, became central in this network. OCsángó, $\square$ Not Csángó.

The total number of relations is even smaller than in the previous case, counting less than 150 relations. Yet it is important to say that in this case the number of actors who are connected to the Csángó matter only through one actor is smaller. The greater proportion of the 142 relations is summed up by inner-group ties. It is also important to acknowledge that in this case all new central actors are Csángó. Network data underlie what interviewees from Hungary said, namely that the Csángó matter should be represented and organized first of all by Csángós and not by someone who moved to Moldova from Transylvania and/or Hungary. S30 and S31 are recognized members of the Csángó elite, to whom the young generation often measures themselves and others. In network aspects they are central - based on degree - only in the Barátikör, which means that they have relations that position them among central actors only in a network that concerns Csángós living in Hungary.

Having seen how the cooperation network changes if by restricting it to one or the other group that are in conflict, another network needs to be analyzed, in which the one person who is named as the origin of the conflict is to be excluded. 


\subsubsection{Conflict solution (Hypothetical network without the most central actor)}

The question is that by excluding S10 who would take the leading position over? In network aspects excluding S10 brings benefit to the matter or disadvantage? or maybe doesn't make any difference at all?

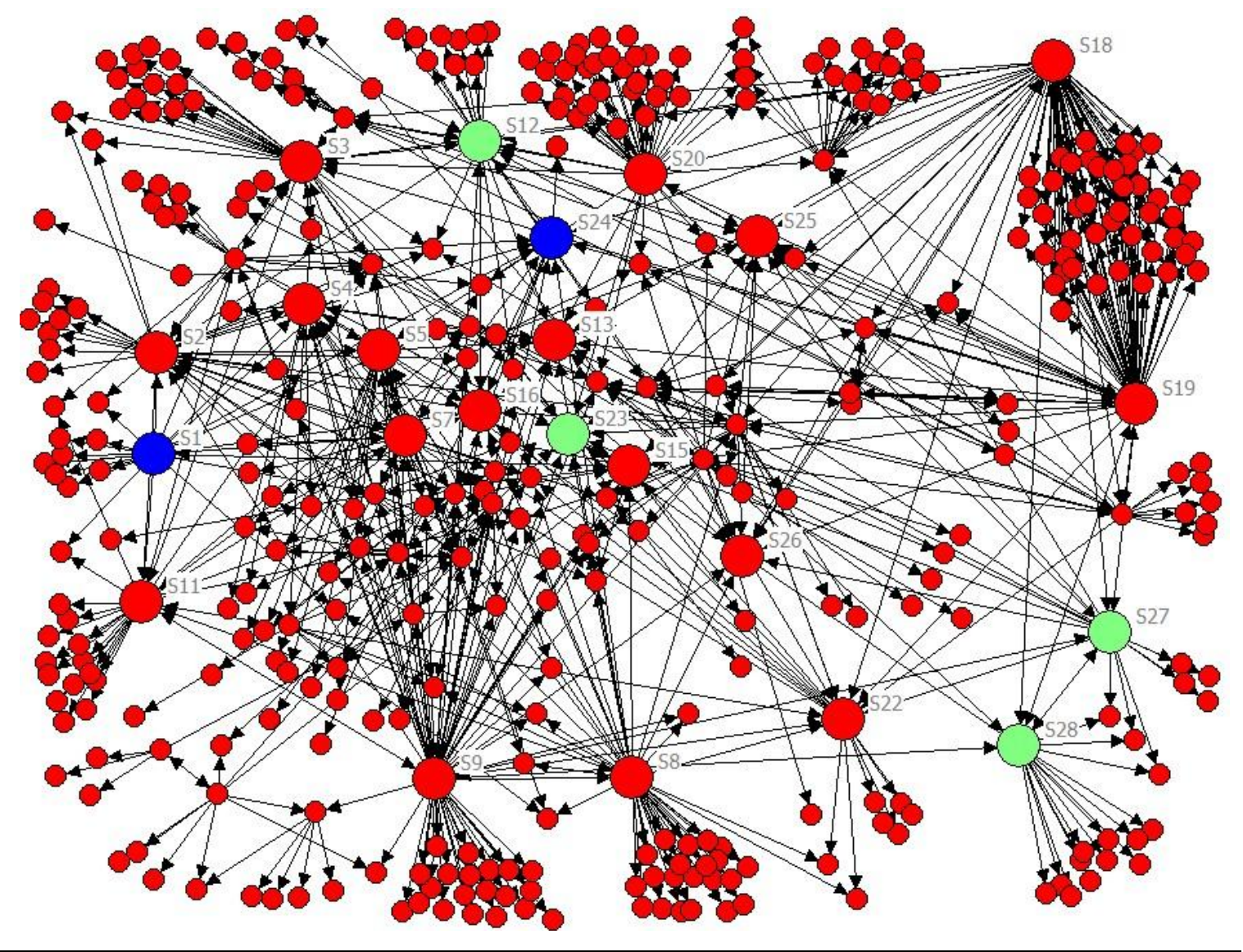

Figure 24: Hypothetical network of the Csángó matter by excluding S10

Legend: •named actors, - central figure, @not central anymore, became central in this network. OCsángó, $\square$ Not Csángó.

Excluding S10 and those who are connected only through him the total number of relations is 760 the change of number of relations is quite substantial. Not knowing whether these actors would remain active by being linked to someone else, the loss is even greater. Many of these actors were members of the political sphere and the media.

By focusing on In-Degree it can be seen that leading position is taken over by S25, another (non-Csángó) employee of the MCSMSZ office, followed by S2 and S4, members of the Csángó elite living in Hungary. 


\subsection{Hypothesis 2: Elite defined by migration experiences}

Motto:

"Our analytical lens must necessarily broaden and deepen because migrants are often embedded in multi-layered, multi-situated transnational social fields, encompassing those who move and those who stay behind. As a result, basic assumptions about social institutions such as the family, citizenship, and nation-states need to be revisited."

(Levitt \& Glick Schiller, 2004:1003)

For a young Csángó - and for that matter for many other members of the young generation of Eastern Europe or any other less developed region of the world - there are two very important decisions to take. First is whether they wish to accumulate human capital by learning or to achieve material welfare by working, and second opting to go abroad in a more developed region, country or to choose to stay at home and try to prosper there. Hegyeli wrote in his article that because education and teaching does not have a high importance the prestige of having a degree will grow because "families will realize, that through education one can fastly prevail and ascend on the social lader in the more and more occidentalising Romanian society as well." (Hegyeli, 2005:234) Migration experiences can affects someones chances of becoming an elite member since as Wallace and colleaques pointed out the "buffer zone between East and West" should be interpreted through the lens of mobility rather than a one way migration. (Wallace, et al., 1996)

The following pages are presenting the answers given by interviewees to these question how the option of migartion did or did not appear in their lifepath and how they think about the dichotomy of learning and guest working.

\subsubsection{Moldova, Transylvania, Hungary. Places and their roles in the life-path of Csángó elites}

In order to answer the hypothesis it is necessary to analyze the roles of geographic locations - and experiences encountered there - in the life path of the Csángó elite. Accumulating professional knowledge, learning the literary Hungarian, being able to evolve professionally are only some of the consequences of migration of Csángós to Transylvania and Hungary. During interviews, it became obvious that one of the first consequences of learning, working, living in Transylvania or Hungary is the confrontation with the „Csángó” concept and the fact that they are seen as Csángós, as different from others. Those experiences that interview subjects encountered during their journey in Transylvania and Hungary and how these experiences shaped their identity and way of thinking about the Csángó matter and about Csángó elites will be presented in the following pages. 
Several members of the Csángó elite chose to settle in Hungary or Transylvania, or chose to go/go back from Hungary to Transylvania. Especially for those who learned and lived for several years in Széklerland it was much easier to accommodate there than to return to Moldova. The decision of returning to Moldova is highly influenced by getting married in Hungary or Transylvania, especially if the husband or wife is from Hungary returning and living in a majority Romanian society is not only difficult but for some of the respondents seemed impossible. We can find migration experiences in the life-paths of many of those who are living in Moldova as well. Why have they chosen to return, was it because they felt a duty toward the original community, was it because of the difficulties of integrating in Hungary, or simply because they thought that raising a child is safer in Moldova as in Budapest.

„Ugye Csíkszeredába beilleszkedtem, meg jól éreztem magamat, meg minden, de Jászberényben már nem annyira. ... Megvolt a letelepedésünk meg minden, a papírok rendezödtek csak úgy valahogy nem, nem éreztük jól magunkat, nem fogadtak be szerintem. ... Szerintem nagyobb volt a honvágy, mint az hogy ott tovább élni."222 (36-50 years old employee living in Moldova)

One important aspect of the elite education of Csángós in Transylvania was whether they will be able to return to Moldova or not. Parents were conscious that by opting for their children to learn in Transylvania when they return to Moldova will encounter serious difficulties.

“89-90 után megjelent a lehetőség a magyar nemzethez tartózás, a magyar nyelv a hagyományos kultúra megörzésének, ápolásának a lehetősége, mint egy hiány. Hogyan próbálták ezt a hiányt pótolni, gyerekek százai indultak el szerencsét próbálni. Egy más világba kerültek, mindenik a maga próbatételét meg kellett, hogy állja, lekellett küzdje a nehézségeket. A nehézségek is fokozódtak, ugyanakkor saját magukat is keresték, még most is keresik s így próbálnak visszaérni, hogy a hiányt betöltsék. Persze útjukba nagyon sok nehézség és az álhösök - mint a mesékben - kerültek, akik késleltetik, megakadályozzák, kihasználják, manipulálják a helyzetet. Saját magam életéböl tudom nagyon nehéz, nagyon nehéz célba érni és ki tudja, csak a Jóisten tudja ki hogyan ér célba. De mindenki a maga felkészültsége, tehetsége, hivatástudata szellemében teljesiti szolgálatát, ki a családját neveli magyar emberként, ki a szakmájában, ki a kutatásban, ki a közösség felépitésében bent a programban és ki egyáltalán azzal hogy nem bánta meg, hogy elindult az útón, szép életet élö ember. Én így látom, és nem tudnám azt mondani, márpedig kötelező hazamenni

\footnotetext{
${ }^{222}$ In Csíkszereda I managed to integrate, it was nice and everything, buti n Jászberény (HU) not so much ... We had the permanent residence permit, paper s were in order only that we didn't like itt here, it seemed to me that we were not accepted there.... I think that homesick was greater than the wish to remain and live there.
} 
és otthon dolgozni, rájön ö magától mikor tud hazamenni és mikor tud otthon dolgozni.

Anélkül, hogy valaki kötelezte volna öket volt aki hazament volt aki nem ment haza, volt olyan aki közvetve segit. "223 (older than 51 current leader living in Transylvania)

At the beginning the economic background of the family was also taken in consideration when choosing the children for scholarship. This is one aspect that in the long term also influenced the returns of graduated young Csángós, since planning without having any certainties is difficult; if a child had no support prior to university they will have the same bad situation after graduation as well.

"Kérdés hogy mire menjen haza? Semmire! Na most otthon megállni a lábán, egy olyan valakinek aki kezdő a pályán, semmiféle anyagi háttere nincs az megint egy ilyen ... Gazdasági szempontok vannak a dolog hátterében gondolom. Mindig ez volt, mindig. "224 (36-50 years old current leader living in Hungary)

Others go forward and say that this young generation of Csángós who received a degree in Hungary might return sometimes, but their integration into the original outmigrating community is hard and maybe is not even compulsory. These people might serve better these emissive communities and the Csángó matter as well by remaining in Hungary where or from where they have a strong lobby power.

"Elképzelhetö hogy egy-egy estben megtörténik, de nem hiszem, hogy ezek már vissza tudnának menni és nem is vagyok benne biztos, hogy olyan nagyon kellene. Hát énnekem az a véleményem hogy ök valahol megtették a feladatukat azzal, hogy elsö generációként, és még most is nagyon elkötelezettként, a csángó ügyet viszik ahol tudják., ${ }^{, 225}$ (older than 51 current leader living in Hungary)

\footnotetext{
${ }^{223}$ After 89-90 there appeared the possibility to belong to the Hungarian nation, the Hungarian language, the possibility of preserving the traditional culture as a deficiency. How they tried to to fill this gap, hundreds of children enrolled to try their fortune. They ended up in a different world, each had to face their own tests, had to overcome their own difficulties. Difficulties intensified and in the same time time they were seraching themselves, they still do, and this is how they try to trun back and fill the lack. Of coursein their path difficulties and several false heroes appeared, just like in fables, who are delaying, preventing, exploiting and manipulating the situation. I know from my own life that is very difficult, very difficult to achieve the goal, and who knows, only God knows how they reach their destination. But all of them serve the goal based on their preparedness, talent, vocation, by raising a family as Hungarian person, in their profession, research, in the development of the community being present in the program (MCSMSZ) and even by not being sorry for taking this road and living a nice life. This is how I see it, and I could not say to anyone that is compulsory to go home and work there, they will figure out on their own can they go home and work home. Without being obligated, some returned, some didn't, and some are helping indirectly.

${ }^{224}$ The question is why to go home? For nothing! To stand on your feet at home, when one is a beginner on the work field, has no material background, is ... There are economic aspect at the bottom of things. There were always like this, always.

${ }^{225}$ It is possible that in some cases it might happen, but I don't think that these can return and I am not sure that they necessarily should. My opinion is that they did what they had to by being a first generation, and being very commited, are representign the Csángó matter wherever they can.
} 
The problem regarding them stands in the fact that while these people can and are seen as Csángó elites it is almost certain that their children will be full members of the receiving country rather than second generation of the Csángó elite if so. Interviewees living in Hungary argue that the question of having Csángó intellectual strata can be solved by having a Hungarian high school somewhere in Moldova. Hungarian teaching should go further from extra scholar classes and language classes in schools to have a school where all subjects at all levels are taught in Hungarian. The question is under whose responsibility and authority falls this?

„Ez hogy Moldvában nincs középiskola ez egy elképesztö botrány az RMDSZ-nek, tehát az Erdélyi politikai képviseletnek, a Romániai közéletnek a botránya és ebbe szerintem nem szabad belenyugodni. Azért látni kell, hogy vannak változások Romániában. Amikor 90-ben még agyonverték Marosvásárhelyen a Sütőéket, akkor nem gondoltuk volna hogy ennyire elöre tudunk haladni. "226 (older than 51 current leader living in Hungary)

Just as much they are away from their original community they are integrated in the Hungarian society. As one interviewee said you have to find a connection with the community either professionally or through communication or by joining professional interests and communication in order to build a bridge among the two worlds, otherwise the distance is getting bigger and bigger.

„,hogy telik az idö, egyre inkább beépülök ebbe a társadalomba, egyre inkább csak a családom köt a faluhoz, és nem a faluközösség. "227 (36-50 years old employee living in Hungary)

For others the entire life-course is accompanied by migration and the continuous change of Moldova and Hungary. In many cases migrating to Hungary was an opportunity given at a specific moment which one can take or drop. Through the interviews it is just as usual to encounter stories which tell us that leaving Romania was an omnipresent idea, or to find out that it was a decision of a moment.

“Eszembe nem jutott 90-ig, addig egyszer jártam ki az országból, listával Szófiába. Engedélyt kellett kérni és akkor listával mentünk, nem útlevéllel. Föleg miután elváltam én megbizhatatlan elem voltam és mondta a párttitkár, hogy ne váljak el mert a jövőm az meg lesz pecsételödve. De kit érdekelt akkor ez, és akkor ilyen megbizhatatlan elem voltam, és

\footnotetext{
${ }^{226}$ Not having a (Hungarian) middle-school in Moldova is an amazing scandal for the RMDSZ, for the political representation from Transylvania, a scandal of the Romanian public life and I think this should not be resigned. It needs to be seen, that there are changes in Romania. When in 1990 in Marosvásárhely Sütö and other were beaten, then we would not think that we can go forward so much.

${ }^{227}$ As the time passes by, is get to be more and more integrated into this society and more and more I am linked to the village only through my family and not the community.
} 
nem kaphattam útlevelet. ... gondolom ez ,, din oficiu” (hivatalból) volt, és 90-ig nem volt semmi. ${ }^{, 228}$ (older than 51 current leader living in Hungary)

In any case, it proved to be a major step, since many of those who enrolled into this migration were later seen as elites. For many people Hungary was only an intermediate location in their migration pattern, opting to go to Spain or Italy after working for longer or shorter periods in Hungary. Usually they are not named as elites, but living in Hungary - according to elites - had an important influence on them as well, first of all on their ethnic self-identification.

Due to a priest couple families had the opportunity to move in a village from Transylvania where they received a house and some agricultural fields. Through this action the goal was double; on one hand the idea was to slow the Romanization of the region in Transylvania and on the other hand to stop the assimilation of Csángós even if only on the level of couple families. Families were chosen from those who had children enrolled in the Hungarian education in Csíkszereda. Some of these children later studied in Hungary and as such their migration experiences had more steps than of others, having two places in Transylvania to accommodate in, one in Széklerland and one in Mezőség (Transylvanian Flat). As one of them remembers moving with the entire family to Transylvania was not such a big decision to take, the land that was made available for them represented such a guarantee, which was sufficient to reach a decision.

“Édesapám mezögazdász volt mindig is, egyszerü ember, bőven volt lehetősége, volt földje, tudott dolgozni, a családját el tudta látni és ez azt hiszem elég szempont ahhoz, hogy döntsön, hogy akkor ö kiköltözik. "229 (younger than 35 employee living in Hungary)

Parents saw this change of location as an escape from poverty. In Moldova if you don't have a job the only hope is to work in agriculture, but if you do not have land either, situation is much harder. Even so, having all the benefits of moving with the family in Transylvania, there are other obstacles one had to encounter: the change of environment and of culture, and also - once again - being different than the rest.

\footnotetext{
${ }^{228}$ I didn't even think on it, before 90, prior to that I left the country once, with a list to Sofia. We had to ask for persmission and then we went with a list not with passport. Especially after my divorce, I was unreliable, and the party secretary, told me not to divorce because my future will be sealed. But who worried about this ont hat time, so I was an unreliable element, and I could nto receive a passport. ... I think this was ex officio, and unttil 1990 there was nothing.

${ }^{229}$ My father has always been a farmer, a simple man, had plenty opportunity, had land to work on and was able to provide his family, and I think this was enough criteriam for him to decide to move out.
} 
The migration to Transylvania or Hungary involved the younger generation, who wished to study in Hungarian schools - although often they are not aware of the difficulties of this change, and only later they realized and admitted how hard it really was - even if parents disagree with this decision.

„Egyszer megláttam, hogy le volt térdelve a fal mellé. Örökké abba biztunk mikor betegek voltak es minden, kezdtünk imádkozni, hogy az Isten segitsen meg. Mondom hogy iljen vallásos félék voltunk. Mikor béfejezte és felkött onnan kérdem, hogy há mi a baj, valami rosszul van? Oljan sirva azt mondja - m-am rugat la sfinta Rita ca sa-mi dai drumu, sa-ti dea mintea sa-mi dai drumu sa ma duc. ${ }^{, 230}$ (older than 51 employee living in Moldova)

Migration to Transylvania and Hungary influenced not only those Csángós who consider themselves as Csángós or Csángó-Hungarians, but even those who identify themselves as Romanians.

\begin{abstract}
„Dincolo în Ardeal a fost un lucru foarte important, că am putut să învăț limba maghiară, şi asta mi-a prins foarte bine, eu ştiam graiul, graiul care se vorbeşte aici, dar mi-a prins foarte bine că am stat lângă colegi maghiari. Am putut să invățt limba maghiară, şi pe urmă am putut să citesc cărțile cercetătorilor maghiari. Altminteri nu aş fi putut să-mi exprim punctul de vedere. Convenabile sau nu, dar din punctul meu de vedere nu poți să eviți punctele de vedere ştiințifice, decât cunoscând şi ce scrie cel de lângă tine.."231 (36-50 years old current leader living in Moldova)
\end{abstract}

When asked about the consequence of living in Hungary and working as a priest of the Iaşi diocese the answer was that working as a priest in Hungary he changed, he sees the faithful in a different way, and also is more open minded and also sees the differences in how he is seen by the faithful. By holding masses for migrants he realized that the priest is not needed only at the altar, up there, but has to come down among the faithful to understand their problems.

„Nagyon egyszerü elitélni egy embert, mert például miért nem volt vasárnap a templomba, és másképpen mikor látod, hogy azért vannak itt, hogy pénzet is nyerjenek, és ha kap egy munkát vasárnap például 20000Ft-t, biztos, hogy azt választja, jó most nem tudok menni misére, de megyek dolgozni. Ebböl a szempontból is meg kell egy kicsit érteni őket. Az nem

\footnotetext{
${ }^{230}$ Once I saw kneeing near the wall. We always believed when they were sick and everything, we started to pray so God help us. I am telling you we were the religious type. When shefinished praying and stood up I asked if there is any problem, is something wrong. Crying she said, that: I was praying to Saint Rita, to let me go, to give you the wisdom to let me go.

${ }^{231}$ Across, in Transylvania there was an important thing that I learned the Hungarian language which was very useful for me, I knew the idiom, the idiom that is spoken here, but it was useful that I was staying near Hungarian colleagues. I managed to learn the Hungarian language and later I managed to read the books of Hungarian scientists. Otherwise I could not have expressed my opinion. Convenient or not from my point of view you can't avoid scientific views, only by knowing what the next to you writes.
} 
jelenti, hogy számukra nem fontos a hit, hanem fontos a hit, de fontos a család is, és talán azért feláldozza magát, és mondja, jó, evvel egy kicsit haladok, egy lépés elöre megyek. "232 (36-50 years old church representative living in Hungary)

\title{
6.2.2. Education versus guest working
}

The last aspect of the elite characterization is given by the learning/guest working dichotomy which was of high importance for all interviewed elites. Decisions between learning and working is often encountered at very young ages. Prestige and status - very important aspects in elite studies - are largely influenced by this dichotomy, rising questions like what is more important having a degree and a more or less certain job with low income, or working abroad and being able to buy everything they want? Who are the role models for the younger generation?

\begin{abstract}
„Ha vissza gondolunk, hogy ennek elötte az vot az értelmiségi egy faluban, aki ezeket szinte mind tudta, hogy mondjuk, hogy kell meggyógyitani, milyen burjányval vagy efféle, ez vot jó tudás. Aztán az vot, akinek iskolája vot, arra felnéztek. Most már olyan nagy ez a mindennapi ... olyan nehéz ... aki hazajön nagy autókkal, ma az valaki. ${ }^{, 233}$ (older than 51 current leader living in Moldova)
\end{abstract}

Comparing the advantages and disadvantages of education and foreign guest working was a topic that all interviewees considered very important and often brought it to discussion themselves and explained several things with the consequences of this dichotonomy. Guest working created opportunities to prosper in material and economic aspects, while education made it possible to introduce the Csángó matter in the cultural and political sphere. There is no village from where no one was enrolled in transnational migration, and little by little villages are catching up in educational aspects as well.
„,nem hiába van az, hogy nálunk csángóknál nem szelektálódott ki értelmiségi réteg, bár azért most elég jó úton haladunk, de a 30-as évektöl kezdték el őket beszoritani iskolákba és a hetvenes évek végén még mindig nem volt súlya az iskolának. Az osztálytársaimnak fele jött az iskolába, mert kötelezö volt, de nagyon sokat hiányoztak. Azt nem várhatjuk el viszont, hogy mikor kicsi voltál bocs, hogy ütöttelek, hogy menjél dolgozni, de most az lenne a fontos, hogy menjél tanulni. A munkának nagy becsülete van otthon, nagyobb mint a

\footnotetext{
232 Is very simple to judge a man, because did not attend tha mass on Sunday, and is different when you see that they are here (in Hungary) to gain money and he finds some work on Sunday and 20.000 Ft, is more than certain that will opt for that, OK I can't go to mass now, but I go to work. From this aspect they should be understood a bit too. This doesn't mean, that faith is not important to them, faith is important, but family also matters and maybe for this he/she sacrifice him/her self and says that OK, this is good, I make a step forward.

${ }^{233}$ If we think back, before intellectual was someone who knew all this, what herbs heal this and so on, this was good knowledge. Than those, who had a degree, they were respected. Now is so big this everyday .... is difficult ... one who comes home with s big car is someone.
} 
tanulásnak, de ez a tempó így jó, hogy mindig dolgozzon a több ember. Jó irányba megyünk, én nagyon optimista vagyok egyébként, mert láttam olyan embereket, akiknek nem volt megadatva, hogy tanuljanak és nem is tartották fontosnak, még olyan volt osztálytársaim is, akik kiröhögtek, hogy 30 évesen is tanulok most meg külön tanárt fizetnek a gyerekeinek. Szépen átváltanak, látják ezeket a folyamatokat, hogy mégiscsak jó ha tanul az a gyerek. Átlátják ezeket a dolgokat egyre többen. Még mindig kevés, ez az egyre többen, de sokkal több, mint a semmi és alakul. "234 (36-50 years old employee living in Hungary)

Education and learning are seen as important only if material, economic prosperity is associated with it. A serious materialistic approach can be observed, if one can show material achievements as well not only academic successes, the community considers the way how these material outputs are realized secondary to the fact that one has or does not have money, wealth, etc. If someone goes abroad and works for a long time and manages to put aside enough money to buy the usual prestige items, a house and a car has a higher appreciation and prestige than those who have a degree, yet do not possess the objects of esteem.

While education seems to gain privilege in many families, expectations towards those who have a degree is high. Once one finished a university he/she should be able to materially catch up to those who were accumulating all over the years of his education. Usually parents invest in the education for children with the hope that their lives will be easier like that, yet they do so without having a clear understanding of how educational systems are working and how investment in education is profitable on long term.

„Az, hogy ma egyre többen továbbtanulnak a faluból, bárhol egyetemeken, ennek van egy
kicsit olyan ize is, hogy a faluban presztís ez, rámegy ingük, gatyájuk, bele fognak
pusztulni a gyerek iskoláztatásába, de megcsinálják. Erre nagyon sok példa van. Van egy
ilyen olvasata is a dolgoknak az én véleményem szerint, a törekvésnek meg az, hogy, akit
tanulásra biztatnak annak mindenképpen egy könnyebb életet álmodnak. Úgy gondolják,

\footnotetext{
${ }^{234}$ it is not by chance that an intellectual strata wasn't selected among Csángós, although now we are on a pretty good road to this, but they were squeezed into schools from the 30's, and at the end of the 70's school still had no weight. Half of my schoolmates were coming to school, because they had to, but they were very often missing. We can expect that when you were little, sorry that I was beating you to go to work, but now it would be important to study. Work has high value at home, higher than education, but this is allright, that the majority is working. We are going in the right direction, and I am very optimistic because I saw people to whom ther was no opportunity to study and to whom it wasn't important, I have former classmates who were laughing at me that I am 30 and still learning, and now they are paying for special teachers to their children. They are nicely switching, they see these processes, that is still good if that child learns. More and more are comprehending these things. This more and more is still not to many, but is more than nothing and things are taking shape.
} 
hogy ez egy könnyebb életet fog jelenteni, most már látják rajtam, hogy nem könnyebb így sem. ${ }^{, 235}$ (36-50 years old employee living in Hungary)

Studying and education is seen by those who themselves have a degree, as the only possibility through which a Csángó and the entire community can develop.

„Nekem, erröl van egy kialakult véleményem. Én azt mondom, hogy mi csángók csak a tanulással tudunk kiemelkedni onnan, nincsen semmi más. Mert meglehet szerezni az Audi 8-ast épitkezésböl meg takaritásból, de az egy kicsit nehéz. Meg, egy társadalmat nem ezek határoznak meg, nem csak az anyagiak határozzák meg. Jó legyen Audi8-assal a faluba, de azért mégis ha szóba kéne álljanak valakivel, nem is juthatna oda, bizonyos társadalmi rétegekbe nem is kerülhetne be. Úgyhogy én nekem az a vesszöparipám, hogy aki csak tud, az tanuljon. Csak igy tudunk felemelkedni s igy tudunk megörizni mindent, igy tudnak felfigyelni ránk. "236 (older than 51 former leader living in Hungary)

Not only educated parents see the importance of learning, guest workers too, realized that having a degree and a profession highly improves the odds of having a good job. Migration - with the goal of studying or working - ensured new norms as it concerns education and its importance.

\begin{abstract}
„Van olyan es, hogy elvégezte magyarul de elment dolgozni Franciaországba s akkor oda adja a gyermekét az egyetemre Franciaországba vagy Spanyolországban. De az a jó ahogy gondolkodnak erre is, hogy kell tanulni. [...] De vot olyan es, hogy a tíz osztályba vot a léányka Felsölakon, az apja, anyja dolgozott Olaszországba s nem hagyták a léánykát befejezze az iskolát, mert milyen jó ha van pénzük, dolgozzál. Osztán nem tudom, hogy ottan folytatta-e, nem-e, de tudom, hogy kirontották az iskolából ez miatt. S annyira fáj, mert jó tanuló vot a léányka. S kirontották az iskolából, nekik többet számit, hogy keressen pénzt mind akkor tanuljon. ${ }^{, 237}$ (older than 51 current leader living in Moldova)
\end{abstract}

\footnotetext{
${ }^{235}$ The fact that today, more and more are learning from the village in universities, has an interpretation that this is something of prestige in the locality, they are spending all they have, and they will bedestroyed by the education of the child, but they will do it. There are many examples to this. As it concerns me I think that there is such an interpretation and for the pursuit the fact that for those who are urged to study for them in all cases an easier life is dreamt. They think, that this mean an easier life, now they can see my case, that is not easier like this either.

${ }^{236}$ I have a firm opinion about this. I say that us, Csángós can emerge from there only through education, there is nothing else. Because one can get the Audi 8 from constructing or housekeeping but that is bit a difficult. And a society is not defined by these, or not only the material things are defining. OK have an Audi 8 in the village, but when they have to discuss with someone, ... they can't even reach certain social stratas, they can't enter. So this is my hobby-horse, that anyone who can, should learn. Thsi is the only way to emerge and to preserve everything; this is how we can be noticed.

${ }^{237}$ There is something like, graduated in Hungarian but went to work in France and gave his/her children to university in France or in Spain. What is good is that they think on this, that learning is necessary. [...] But it was a case that a girl was in the tenth grade in Felsőlak, her mother and father were working in Italy and didn't allow the girl to finish the school, because how good is when one has money, you should work. Then, I don't know whether there she continued or not, but I know that they took her out from school because of this. And this hurts so much, because she studied well. They took her out from school, for them it mattered more to gain money than to study.
} 
Speaking with teachers of the MCSMSZ became obvious that children enrolled in schools could see clearly that they have to continue their studies otherwise the only opportunity is to work in construction as unskilled laborers. The problem stands in not having too many positive examples, worthy to follow life courses, in the fields of education. Basically they see that those who work in Spain or Italy can afford everything while those who study are - materially at least - stagnating. For those who dropped school, even if it was only to one or two years, the value of education is very low, the odds of returning to school are almost none. Opinion often encountered was that the prestige of education would be higher if proper informing would be done about learning opportunities, financing education, and consequences of learning or not learning.

„,Ahol a szülö csak a munkával van elfoglalva, a gyerek úgy nö fel hogy észre se veszik hogy 8-ik osztályt fejezi be és kellene tovább irányitani. Hát, egyszerüen akkor ébrednek fel hogy most kellene. Ha épp akkor veszekednek a családon belül ugyanúgy megfeledkeznek a gyerekröl s akkor minden elsiklott. De addig is ha nem foglalkoznak konkrétan a továbbtanulással akkor nincs felkészítve. Hát késö és bekell gyakorolni ezt az egészet, tehát ha van egy út ahova, amire ráraknak és szépen halad akkor megvan a garanciája, hogy meg is marad, viszont hogyha véletlenül bejut egy iskolába akár Bákóba mert ott szoktak elsöre menni, megkezdeni hogy továbbtanulást azzal a nehézséggel néznek szembe hogy a tantárgyak egyszerüen sok, nem birja, néha hiányzik és akkor kész, be is fejezte. ${ }^{238}$ (36-50 years old current leader living in Hungary)

Continuing education is not referring to the university level, it is first of all going to high school (9-12 grades). Before anything, family is the decisive milieu in opting to study or work. It can be seen that having at least one parent with education (baccalaureate or higher) strongly influences the option of children, having a family member who is learning or once was learning in Széklerland or Hungary, positively influences a child's option.

„Nekem nagyon fontos a tanulás, ugye én is járok egyetemre. Úgyhogy, mondják is a szomszédok, hogy a lányaink nem mennek a mezöre meg nem tudom hova nem mennek, nem mondom hogy nem teszi oda magát csinálja, a ház körül takarít meg mindent

\footnotetext{
${ }^{238}$ Where parents are busy with work only, child is growing up that they did not even notice that finished $8^{\text {th }}$ grade and should be directed forward. Simply they wake up, that now is the time. If the parents are fighting with then, they are forgetting about the children and everything slippes away. But even until then if they are not focusing on continuing education then the child is not prepared. Is too late, and all should be practiced, if there is a road somewhere, on which one departs and goes nicely than there is a guarantee that he/she will last, but if accidentally enters a school even in Bacaz, because first of all they go there to continue their studies they encounter the difficulty that subjects are simply too much, can't handle, occasionally is missing school and that's it is already finished.
} 
csinálnak, de úgy valahogy én se szeretek a mezöre járni s akkor nem., ${ }^{, 239}$ (36-50 years old employee living in Moldova)

Education can be seen as an impairment as well, especially if graduation is not followed by success. Csángós receiving a degree at Hungarian universities when returning to Moldova often realize that they can't utilize their education, their degree is not recognized, or they can't find a job in their profession. Years invested in studies might seem lost years, especially if others with no education seem to prosper.

„Hát nézd meg a másiknak a fiát, milyen autóval jött haza, s már házat épitett, hát menny dologra fiam, menj, stb. látod mi értelme annyi iskolának. Igazság szerint nem mondom meg, hogy van ... mert az én testvéreim is abban reménykednek ... mondom, hogy én kölcsönt kértem, és nem sürgetik a pénzt visszaadni, mert valami csak lesz belöle, mert én mondtam nekik, sajnálom, nem tudom megadni. Hát, én ilyenkor föld alá ásom magamat ök annyira biztosak benne, hogy ennyit tanultam ugye, valami csak lesz belöle. Igazságos mércével mérve, egy föiskola szinte semmi, de az ök szemükbe az sok minden, mert tudják, hogy mennyi évig csináltam, jártam, tanultam és, hogy ök ennyi év alatt mennyi mindent szedtek össze, mit csináltak. Hát akkor nem hiába csináltam, majd csak lesz valami. "240 (36-50 years old employee living in Moldova)

Opting for education implies that success won't be fast, especially that Csángós are usually applying to degrees in the field of humanities, rather than fields that bring faster self realization (engineering, nature sciences, etc.)

„Általában humán osztályba mentünk, tudniillik ... reál szakon, vagy reál területen eleve olyan nagy volt a lemaradás a Moldvából jött oktatási problémák miatt, hogy azt nagyon kevesen tudták behozni. A humán szak egy kicsit mindig közelebb állt az emberhez, magyar nyelvet kellett tudni jól, esetleg még egy nyelvet, egy nyelv elönybe voltunk eleve a román nyelvtudással tehát így rohadt könnyü volt ... úgy tudom, hogy szinte mindenki humán szakra ment tovább. ${ }^{, 241}$ (younger than 35 employee living in Hungary)

\footnotetext{
${ }^{239}$ For me education is very important, I study at university too. So, neigbours are saying that the girls are not going to the fields, and not going I don't know where, I am not saying that they are not working, cleaning around the house and doing everything but I don't like to work the fields and then no.

${ }^{240}$ Look at the son of the other one, what car he came home with, and already built a house, go to work son, go, etc. you can see the sense of so much school. To be honest, I can' tell how it is, because I ... my brothers are hoping that ... I said that I have borrowed and they are not urging me to give back the money, because something will be, because I have told them, that I am sorry I can't give back. In these moments, Iwould like to bury myself, they are so sure that if I have learned so much something will be. Measuring with truthful measures, a high-school is close to nothing, but in their eyes it means a lot, because they know for how many years I was doing it, I was attending, learning and during those years how much they have collected, what they did. So it wasn't useless, something will be.

${ }^{241}$ Usually we went to human classes, because ... in real departments, subjects originally there were so big backlogs due to the education problems in Moldova, that very few were able to catch up. Human profile was always a bit closer to one, had to know well the Hungarian language, and if possible another
} 
In a traditional-rural society work is very important and not just any work. One has to work the land, has to take care of the animals, and if he fails to do these it doesn't matter what other kind of work he is doing, in the opinion of the community he is not working. Working on a computer, or in an office does not exempt anyone from traditional works, even if lands were parceled out among the many children and traditional works are not very profitable some works has to be done.

Foreign guest working is very tempting especially when providing high salaries for unskilled laborers as well.

\begin{abstract}
„Munka, mert pénz jön. Elnézem ezeket a fiatal lányokat akik azért tudnának tovább tanulni, mert van ez a lehetöség hogy kapnak ösztöndíjat Magyarországra és nem azt választják, mert befejezik az iskolát és Olaszország vagy Spanyolország az irány. Mondjuk aki Csíkszeredába van, az megkapja az információt s akkor is nem mindenki választja azt, hogy tanuljon. Legtöbbször olyan gyerekek akik 12 végzik el románul Bákóba a szülö meg se kérdi töle hogy mit szeretne. "242 (36-50 years old employee living in Moldova)
\end{abstract}

They go to the country that pays better and where the migration channels are active. In a couple years they manage to build a house in the home village, and buy a car. Basically these are the first two goals a migrant plans to fulfill.

„ök ott ezért dolgoznak, hogy épitsenek egy jó házat, vegyenek egy jó autót. Máshogy értékelik, mondjuk ott Olaszországba, ha vigyáz egy öregre, akkor 700 - 800 eurot keres havonta s az meg es marad a zsebébe mert ottan es lakik, ott eszik, ott minden. Ez a pénz megmarad a zsebébe, s szép pénz amit itten Romániában ö nem nyer. ${ }^{, 243}$ (older than 51 current leader living in Moldova)

Work has negatives side effects as well, beyond accumulating material wealth is important to acknowledge that by enrolling to a work place where the salary compensates a lack of skills, migrants are likely to constitute a strata that after a specific age will be without income.

language, we were in one language advantage because of the Romanian language so like that was very very easy ... I know that almost everyone went to human profession.

242 Work, because there is money in it. I see these young girls who could study, because there exists the possibility to receive scholarship to Hungary and they are not opting for this, they finish school and the target is Italy and Spain. Those who are in Miercurea Ciuc receive the information and even so not everyone choose to study. Usually children who graduated 12 grades in Bacau and parents doesn't even ask what they want.

243 they are working there, can't you see how many houses are built, this is why they work, to build a good house, to buy a good car. They are appreciated differently in Italy, taking care of an old man, gains monthly 700-800 euros and can keep in his/her pocket because he/she lives there, eats there and everything. This money remains in his/her pocket, and is good money which here, in Romanian he would not make. 
„Onnan kell kiindulni, és ez a fiatalokra is vonatkozik, 30-40 év múlva vagy 50 év múlva, elkövetkezik az az idö, amikor azt mondják hogy te már öreg vagy s innentöl kezdve abszolút kilátástalanná válik az élete mert még udvart takarítani se jó mert a másik megcsinálja hamarabb. ${ }^{244}$ (older than 51 current leader living in Hungary)

According to the usual scenario after a couple of months migrants return home, where they have a house and some money set aside. It is not unusual that when they run out of money they enroll to migration as well for a determinate period. Usually returned migrants don't invest in businesses, they continue the typical life of the community members. There are some innovators, who start a travel or a delivery company, or continue to organize foreign guest working by linking suppliers with demanders, but these cases are quite rare.

„semmiképpen nem értékelhetö pozitivan az a megközelités, hogy menjen külföldre, akinek csak birja a lába. Itt az államnak kellett volna okoskodni, hogy igen is a helyi munkalehetöségeket valamilyen módon biztositani, nem az hogy pénzt adjon, tanitsa meg halászni az embereket, hanem lehetöségeket adjon ezekre. Lészped egy ötezer fös község, én nem találtam ott egy cipészt, nem találtam egy asztalost ott, semmit nem találtam. Semmit nem találtam, láttam ott üzleteket, ami 10-20 négyzetméteres raktárostól, meg a kocsmákat. ${ }^{, 245}$ (older than 51 current leader living in Hungary)

While migrants see abroad the patterns of consumptions - one has to have a house, a car, TV, washing machine, computer, etc. - yet they don't learn how to invest the accumulated wealth into a long-term income source.

Some think that migration experiences matter, regardless of their goal. Working abroad is just as beneficial as education, even if one work as unskilled will accumulate knowledge. Those who agree with that, usually agree on another thing as well, namely that these migrants will return to the village and will use their accumulated knowledge there. Whether they return of necessity because not having a profession, getting older is more and more difficult to find a job, so the only option is to return remains an open question.

One important aspect of the Csángó matter was reenactment, the maintaining of folk customs, which is also related with the dichotomy of learning and guest working,

\footnotetext{
${ }^{244}$ It should start from and this applies to the youngs as well, that if they don't learn, in 30-40 years or in 50 years, there comes a time, when they will be told that they are too old, and from then on, their life will be absolutely hopeless, because he/she is not good for cleaning the yard because other can do faster.

${ }^{245}$ This approach that all who can, should go abroad can't be seen as positive at all. Here the state should've been smarter, to ensure local work opportunities in some way, not to give money, but to teach people fishing, to give opportunities to this. Lészped is a village of five thousand habitants, I could not find a shoemaker, could not find a carpenter there, couldn't find anything. I could not find anything, I saw shops that are 10-20 squaremeters with storehouse, and taverns.
} 
especially that the young generation is taken abroad by school or workplace. Giving forward the knowledge of elders is difficult when the young generation is not present.

„A fiatalok mind elmennek munkára, ide-oda, nem csak Magyarországra, hanem az egész Európába elvannak szertülve s akkor nincs kivel foglalkozni. Elég szép csoportom vót, kimentünk Németországba velik s mikor visszaérkeztek mindenki Olaszba ment senki nem jött haza. ${ }^{, 246}$ (older than 51 current leader living in Moldova)

One interviewee pointed out the importance of the Csángó matter and Hungarian teaching in the dichotomy of education and guest working:

\begin{abstract}
„Első sorban a két nyelvnek a románnak meg a magyarnak, a szisztematikus szétválasztásával. Tudniillik Moldvában használják az archaikus csángó nyelvet, használják a román nyelvet, most már kevergetik bele a magyar irodalmi nyelvnek a szavait is, meg esetleg angol szavakat, amiket hallanak a tévében. Tehát ez a kevertnyelvüség azt eredményezi, hogy a gyerek fonetikusan írja le amit magyarul mond a tanár neki. Ilyen tudással az égvilágon sehova nem tud menni tovább tanulni. "247 (older than 51 employee living in Moldova)
\end{abstract}

The Hungarian teaching provides motivation for children to study, to realize that education is important. They are thought that they need to live more consciously and in that the most important role is played by the family and by teachers.

\begin{abstract}
„, Mint minden fiatal, eléggé türelmetlenek a csángó fiatalok is, nem úgy látom, hogy átlátnák a pénzszerzés logikáját, hogy elöbb befektetek aztán szerzek pénzt. Mondjuk, itt úgy értem azzal fektet be, hogy tanul. Igenis tudatosabban kellene élni, de azt mondom, hogy nagyon meg kell adni a motivációt és nagyon nagy a felelössége a szülöknek, tanároknak, nevelöknek. Csángó földön a motiváció legtöbbször a kirándulás. Ha jó eredményt érek el magyar nyelvböl, akkor kirándulhatok, táborban vehetek részt. Na most már ezek a táborok és kirándulások stratégiailag úgy vannak megszervezve, hogy a gyerekek sokat látnak, megnyilik a látásmódjuk is. Megértik azt is, hogy meg kell dolgozni, azért amit el akarnak érni az életben. Igazából még arra is szükség lenne, hogy megtanítani a gyerekeket álmodni, tervezni és az álmokért, a célok megvalósitásáért tenni is. "248 (younger than 35 church representative living in Hungary)
\end{abstract}

\footnotetext{
${ }^{246}$ The youth are leaving to work, here and there, not only to Hungary but they are scattered all over Europe and there is no one to deal with. I had a fairly nice group, we went to Germany and when we returned all wnet to Italy, nobody came home.

${ }^{247}$ First of all the systematic separation of the two languages, the Romanian and the Hungarian. Needed to know that in Moldova the archaic csángó language, the Romanian language is in use, now they are mixing in concepts of the literary Hungarian, and possibly English words that they hear from the TV. So this mixed-language results, that the children are writing phonetically what the teachers tells him/her in Hungarian. With this kind of knowledge one can't go anywhere to continue his/her education.

${ }^{248}$ Like all youth, csángó youth are impatient as well, I can't see that they understand the logic of making money, that first I invest then I make money. Let's say, here I understand learning by investment. Should indeed live more consciously, but I say that strong motivation should be given and parents, teachers have
} 


\title{
6.3. Hypothesis 3: Elite defined by migration experiences and roles and positions in the Csángó matter network
}

\author{
Motto: \\ "Kis millióan vagyunk, akik hasonló életkörülmények között elhagyjuk a szülöföldet és \\ aztán a családhoz hazamegyünk, bezárjuk a kaput. Ez is megtörténhetett volna, hogy van a \\ család és akkor nem megyek ki az utcára, meg nem megyek gyüjteni, megtörténhetett volna, \\ de nem ez történt. Nem tudom, hogy miért, de semmi esetre sem azért, hogy én itt \\ Budapesten kiváljak, mert erre nem használható ez föl, meg hát akkor még mindig nincs \\ válasz arra, hogy miért pont én, miért nem a többiek. Ez egyáltalán nem arról szól, hogy \\ valaki valahonnan jön és abból a világból, itt teremt egy jó karriert. Szó nincs róla. "249,"
}

(36-50 years old employee living in Hungary)

When speaking about the Csángó matter, some actors involved in it are often accused of participating and using the matter only in personal business goals. To build up a carreer or to gain material wealth or social capital from it.

When the education of a so called intellectual stratum is done outside of the region which should be represented and served by him/her the question needed to be asked is what happens after graduation. In our case is the so called elite and intellectual teaching fulfilling its goal? Are the graduated Csángós returning to Moldova or they remain in Hungary or Transylvania? The answer is dual, while many are returning; many opt to remain in Hungary or Transylvania.

„,Iiiigen, hogy elhagytuk a közösségünket, és magára hagytuk a közösségünket, de hát ez nem úgy müködik, nem vagyunk matematikai absztrakciók, azért itt életek vannak. "250 (36-50 years old employee living in Hungary)

„El, ellehetetlenitett, mert pl. most ugye haza megy tanitani, nincs ahol tanitani, az iskolák nem fogadják be. "251 (older than 51 employee living in Hungary)

In the case of those who remain in Hungary or Transylvania, beside the difficulties encountered in Moldova we have to count with the change of identity as well. (Iancu, 2006)

\footnotetext{
a great responsibility in this. In Csángó land motivations mostly are the excursions. If I have good results in Hungarian language, then I can go to trips, to excursions. Now, these camps and trips are strategically organized in a way that children can see much, open their vision. They also understand that they have to work to achieve something in life. It would be also useful to teach children to dream, to plan and to do for the fulfillment of dreams and goals.

${ }^{249}$ There are small millions of us, who in similar circumstances levae their homeland and then they return to the family and close the doors. This might have happened too, that there is trhe family and I don't leave the house, I am not going to collect, this might have happened but didn't. I don't know why, but not at all in order to excel here in Budapest, because this can't be used for this, and then there is still no answer to why exactly me, why not the others. This is not about one coming from one place, and from that world creates a good carrier. Not at all.

${ }^{250}$ Yes, we left our communities, and we abandoned our communities, but this doesn't work like that, we are not mathematic abstractions, there are lifes at stake.

${ }^{251}$ Is impossible, because for example one goes home to teach, there is no place wher to teach, schools are not accepting them.
} 
During the entire network presentation one of the basic questions was the way how network characteristics and network positioning affects, if one will be/is seen as elite and whether geographic location has an effect on the odds of being named as elite.

The relationship among In-Degree ${ }^{252}$, geographic location - focusing on the two regions that appear in a higher proportion, Moldova and Hungary - and whether one was named as elite by others or not is analyzed with SPSS. In order to be Csángó elite, first of all one has to be Csángó ${ }^{253}$, so the analysis was restricted on them only. All those actors who appeared in the cooperation networks yet are not of Csángó origin, identity were excluded. The precondition was expressed by interviewees.

Regression analysis was used to check the relation among In-Degree and elite nomination (0: not named as elite, 1 : named as elite).

\begin{tabular}{l|rrrr} 
& $\mathrm{B}$ & S.E. & Sig. & $\operatorname{Exp}(\mathrm{B})$ \\
\hline In-Degree &, 627 &, 127 &, 000 & 1,871 \\
Constant & $-2,642$ &, 353 &, 000 &, 071 \\
\hline
\end{tabular}

Table 10: Relation among to In-Degree and elite nomination

Every increase of In-Degree (with one extra relation) increases the odds of being named as elite by others with 1,871 times, that is every extra relation increases with $87 \%$ the odds of elite nomination. That means that if 4 people name $\mathrm{A}$ as cooperating with someone, and only 1 named $\mathrm{B}$, the odds of A compared to the odds of B of being named as elite is 3,95 times higher. Having a significant relationship, urges us to follow the principal idea of combining network related data and statistical analysis.

As a second step the relationship among geographic location (0: Hungary, 1: Moldova) and one's odds of being named as elite is checked.

\begin{tabular}{l|rrrr} 
& B & S.E. & Sig. & Exp(B) \\
\hline Geographic location & $-3,241$ &, 522 &, 000 &, 039 \\
Constant & 1,386 &, 456 &, 002 & 4,000 \\
\hline
\end{tabular}

Table 11: Relation among one's geographic location and elite nomination

The odds of Csángós living in Moldova to be named as elite is 0,039 times the odds of Csángós living in Hungary, their odds is smaller with 96\%. Although a significant relationship, we have to mention that the number of Csángós living in Moldova is much higher than of those who are settled in Hungary, and using samples with the same size might change the results. However according to the relational data this result is acceptable especially that among respondent the proportion of those living in Hungary respectively in Moldova was quite the same.

\footnotetext{
${ }^{252}$ In-Degree was calculated when ego-alter relations where included only, and alter-alter not.

253 This was a limitation named by almost all interview subjects.
} 
The strong relation among In-Degree and elite nomination and geography and elite nomination was presented. Since In-Degree itself might be influenced by one's geographic location, using linear regression the relation among these two variables is also tested.

\begin{tabular}{l|ccc} 
& B & S.E. & Sig. \\
\hline Constant & 3,833 &, 503 &, 000 \\
Geographic location & $-1,442$ &, 556 &, 010 \\
\hline \multicolumn{2}{r|}{ Table 12: Relation among one's geographic location and In-Degree $\left(\mathbf{R}^{2}=\mathbf{0 , 0 4 0}\right)$} &
\end{tabular}

There is a difference among those Csángós who live in Moldova and those who are settled in Hungary as it concerns their In-Degree in the cooperation network, the difference is 1,442 . In Hungary in average the In-Degree is 3,83, in Moldova the average is smaller with 1,442 . It seems that region has a significant influence on one's In-Degree, and as earlier presented In-Degree has a significant effect on elite nomination.

In order to answer this question whether geographic location has an influence on the effect of In-Degree on elite nomination a regression analysis is conducted by introducing an interaction variable. The relationship of the three variables can be visualized as it follows.

\section{Geographic location}

\section{In-Degree}

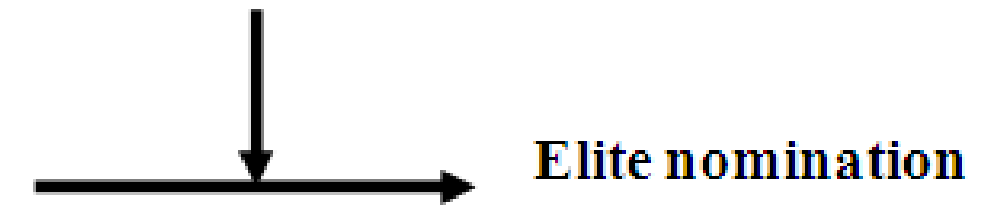

Using the same three variables: elite nomination (0: not being named as elite, 1 : being named as elite) as the dependent variable, while In-Degree and Geographic location (0: Hungary, 1: Moldova) the two independent variables the following logistic regression results were received. The interaction effect was introduced by an INTER variable, created with the multiplication of the independent variables. (INTER $=$ InDegree*geographic location)

\begin{tabular}{l|rrrr} 
& B & S.E. & Sig. & Exp(B) \\
\hline In-Degree & 1,496 &, 932 &, 109 & 4,463 \\
Geographic location & $-2,848$ & 1,427 &, 046 &, 058 \\
INTER &,- 779 &, 944 &, 409 &, 459 \\
Constant & $-1,384$ & 1,290 &, 283 &, 250 \\
\hline
\end{tabular}

Table 13: Relation among Elite nomination, In-Degree and Geographic location 
By introducing the interaction effect, the original independent variable loses it's significant effect. The INTER variable is not significant either. Yet interpreting the results might bring some extras worthy to think through. In the case of Csángós from Moldova the profit of high In-Degree is 0,459 times smaller than in the case of Csángós from Hungary.

To have a better insight the analysis of the regression function is continued through the regression function:

$Y=b_{0}+b_{1} *$ In-Degree $+b_{2} * G e o g r a p h i c ~ l o c a t i o n+b_{3} * I N T E R$

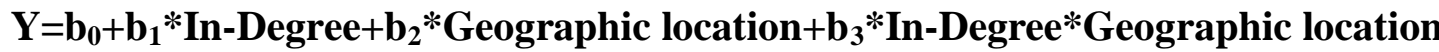

The regression is reorganized, than the values of geography dummy are susbstituted in a way to show the effect of In-Degree by region dummy

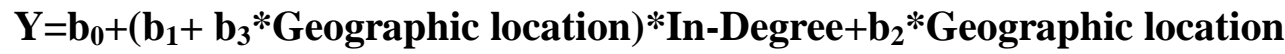

In the case of Csángós settled in Hungary the effect of In-Degree is:

$$
\left(b_{1}+b_{3} * \text { Geographic location }\right)=b_{1}+b_{3} * 0=1,496
$$

In the case of Csángós living in Moldova the effect of In-Degree is:

$\left(b_{1}+b_{3} *\right.$ Geographic location $)=b_{1}+b_{3} * 1=1,496+(-, 779)=0,717$

As a conclusion it can be said that for Csángós living in Moldova a high InDegree decreases the logarithm of odds to be named as elite with 0,779 but the results are not significant.

Assuming that results might be distorted by whether one appears as an ego or only as alter a dummy control variable, ego_alter (0: alter, 1:ego) was introduced. There is a strong supposition that those actors of the network who named their personal relations are more likely to have high In-Degree as well. To test this the ego-alter variable was introduced

\begin{tabular}{l|rrrr} 
& B & S.E. & Sig. & Exp(B) \\
\hline In-Degree & 1,584 & 1,001 &, 114 & 4,874 \\
Geographic location & $-2,474$ & 1,561 &, 113 &, 084 \\
INTER &,- 924 & 1,024 &, 367 &, 397 \\
ego_alter &, 656 &, 862 &, 447 & 1,926 \\
Constant & $-1,690$ & 1,420 &, 234 &, 185 \\
\hline
\end{tabular}

Table 14: Relation of Elite nomination, In-Degree and Geographic location layered by ego_alter The most important question was whether the control variable influences the original relation among variables. The ego-alter variable has no significant effect, but since In_degree and INTER variable had no significant effect, testing the relation among the three variables needs further refinement and/or data gathering. 


\subsection{Chapter conclusions}

After the analysis of interviews and networks and even the quantified network data, it is still a valid question whether the elite given by the snowball sampling, and by the Csángó matter cooperation network is seen as elite by the community as well. The question is more available since several members of the elite are not locally present and it might happen that the village is not aware about these activities on one hand, and on a second front - and as an interviewee underlined it - the village might not consider these persons as "people of the village". As mentioned earlier quantitative data was collected in one village, where demographic data, migration concerns and plans were collected. Last three questions of the questionnaire refer to the Csángó elite, to the expected characteristics of the elite, from which the very last question was to name 10 people from the village who have high prestige, have the highest respect.

One of the questions was who is part of the elite and why them. It seemed that second part of the question was much easier than first part. Only nine people were named, nomination has large scattering. The highest nomination is of F.C. with 23 nominations followed by the local priest with 15 nomination. The third most nominated is the father of F.C., F.R. with 12 nominations. I.V. received 5 nominations, all other nominees received less than five nominations, G.M (3), T.V.(2), G.L.(1), G.C.(1) and there was one person named by the community as elite and by the snowballing as well who received 2 nominations in the questionnaire. It is important to mention that this person although lives in Hungary received 2 nominations and while other nominated were named because they are wealthy or highly educated, have a business, etc. this person was seen as elite because deals with Csángós, with the community. FC and F.R. were pointed out during interviews as someones who are seen as successful people by the village. F.C. appeared as elite with the snowball sampling as well. It is important that he is recognized by interviewees from other villages as well.

To have a much clear view about who are appreciated and revered by the local community and how much this list of people is the same with the list that was developed by the snowballing of elites focus is turned to the analysis of the last question.

Based on respect and prestige on first place 35 names were given while in total 238 people were named and other five people were named by their profession (teachers, mayor, entrepreneurs, veterinarian, policeman), some of these later nominations referring to a group of people. Almost half of the nominated ones received at least two 
nominations. There are only 14 people who received at least 10 nominations. Five elites named using the snowballing are from this village, four of them were named as respected, people with high prestige by the community as well. Two who live in the village received high nomination one received 51, while other one was named by 7 people. Third was named by two people, fourth one by one and fifth elite wasn't mentioned.

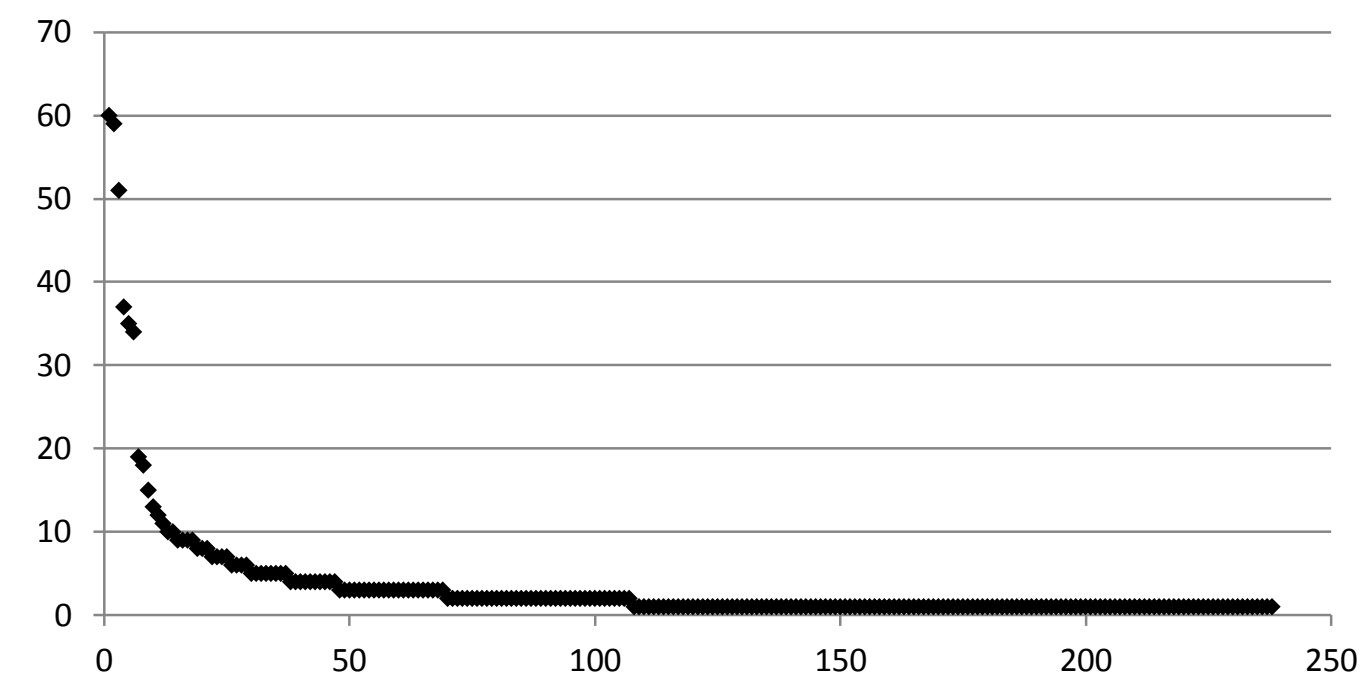

25. Figure: Distribution of elite nominations according to one community

The local priest received - as expected - the highest, 60 nominations. Just like during interviews, in the questionnaires as well, several people think that the first man of the community is the priest, the one with the highest respect. The second highest nomination goes to F.R., who received 59 nominations. F.R. was one of the first of those who enrolled in foreign guest working and later - along with his son F.C. with 51 nominations - organized guest working for several Csángós, mostly from their village to Israel. Both father and son are highly respected in the village and known as people not only with material but with social capital as well. F.C. invested his incomes, and now has a private enterprise. The fourth highest nomination - although it applies for a group of people - goes to the teachers with 42 nominations. One of the teachers - one who teaches in elementary school - T.V. received 37 nominations. A local entrepreneur, working in agriculture and livestock is another person with high nomination, I.V. received 35 nominations, is one of those who recognized the local resources that can be invested and did that without ever enrolling in foreign guest working. He is often pointed out as a counter-exmaple to the mentality that if one wants to achieve something one has to go abroad. Following nominated is the local mailman, B.G. who 
received 34 nominations, after whom there is quite a big difference as it concerns the number of nominations, following person, T.M., is a carpenter, wood carper who received 19 nomination. G.M. with 18 nominations is enrolled in foreign guest working, has worked in Hungary, Israel, Ecuatorial Guinea too, and has all three children in highschool in Csíkszereda, thing that matter in the eyes of the community. C.S. with 15 nominations, works at the church, so is present in the everyday life of the community, and has a son who graduated theology in Iaşi and currently works as a priest in another Csángó community. Following two people are P.I. and I.I., both with 13 nominations, first is the former vice-mayor, who also worked for several years in Israel, and then in Germany, while later one is a local entrepreneur who owns a bar and store in the village, prior to this worked as a forrester in national forests. They are followed by the local forester, G.G. with 12 nominations, the cantor, T.C with 11 nominations and the former school principal G.T. with 10

Going through the nominations one thing is more than obvious namely that respects correlates highly with whether one has a secure, well paying job or not. People who are working at a regular job, have their own investments, are highly respected in the village. Migrants are present among those with high prestige, yet they are not among those with the highest prestige. For many of the nominated ones, migration was an important experience and springboard in self-realization. Interviews made it clear that several elites see the solution of self-realization in education or in foreign guest working, and that for the community working abroad has a higher value. The young generation still sees migration even if not the only path that leads to success and selfachievement but is the more secure and fast one.

To decide whether the opinion of interviewed elites is valid a closer look on the demographic characteristic of respondents is needed. Youngest respondent is 17, while oldest is 73 .

\begin{tabular}{|c|c|c|}
\hline & $\mathrm{N}$ & $\%$ \\
\hline younger than 30 years & 14 & 7,7 \\
\hline 31 to 40 years old & 59 & 32,4 \\
\hline 41 to 50 years old & 36 & 19,8 \\
\hline 51 to 60 years old & 35 & 19,2 \\
\hline older than 61 years & 38 & 20,9 \\
\hline Total & 182 & 100,0 \\
\hline
\end{tabular}

Table 15: Distribution of respondents based on age categories

More than $60 \%$ of respondents have 8 or less graduated classes and only $2 \%$ have a baccalaureate or higher. $23,1 \%$ of the respondent said that they were unemployed at 
least once, while $8,2 \%$ more than once. Although $68,7 \%$ said that they were never unemployed, it is important to know that only $39 \%$ of the respondents have currently a job, while $61 \%$ doesn't. Occupational distribution can be seen in the following table:

\begin{tabular}{|c|c|c|c|c|c|}
\hline Activity & $\mathrm{N}$. & $\%$ & Inactivity & $\mathrm{N}$. & $\%$ \\
\hline Employee & 62 & 34,1 & old-age pension & 43 & 23,6 \\
\hline $\begin{array}{l}\text { self-employed, } \\
\text { entrepreneur, co-contractor }\end{array}$ & 2 & 1,1 & disability pension & 6 & 3,3 \\
\hline pension with a paying job & 2 & 1,1 & $\begin{array}{l}\text { maternity/ childrearing } \\
\text { leave }\end{array}$ & 1 & 0,5 \\
\hline full-time student with a job & 1 & 0,5 & housekeeping & 35 & 19,2 \\
\hline \multirow[t]{3}{*}{ casual work, day laborer } & 8 & 4,4 & searching for first job & 3 & 1,6 \\
\hline & & & unemployed & 6 & 3,3 \\
\hline & & & other & 11 & 6,0 \\
\hline Total & 75 & 41,2 & Total & 105 & 57,7 \\
\hline Missing system & 107 & 58,8 & Missing system & 77 & $42,3 \%$ \\
\hline
\end{tabular}

Table 16: Occupational distribution

What is interesting is that on a scale from 1 to 10 where 10 is the most satisfied with his/her job, 36,1\% said that are maximally satisfied with their work.

\begin{tabular}{lccccccccccc} 
& 1 & 2 & 3 & 4 & 5 & 6 & 7 & 8 & 9 & 10 \\
\hline frequency & & & 3 & 3 & 11 & 6 & 19 & 26 & 17 & 48 \\
Percentage & & 1,6 & 1,6 & 6,0 & 3,3 & 10,4 & 14,3 & 9,3 & 26,4 \\
\hline
\end{tabular}

Table 17: Distribution of job evaluation

High rate of migration in Romania, especially in rural regions is due to the high level of unemployement encountered in villages. One third of respondents were at least once unemployed, and only $39 \%$ has currently a paying job. The proportion of employed seems even lower when taking in consideration that respondents were mostly the head of households.

As it concerns working abroad or having plans in this regard $35,2 \%$ would enroll in migration for a short period.

\begin{tabular}{l|lll}
$\mathrm{N}=182$ & Yes & No & doesn't know \\
\hline for couple weeks or & 64 & 109 & 9 \\
month & $35,2 \%$ & $59,9 \%$ & $4,9 \%$ \\
\hline for couple years & 31 & 140 & 11 \\
& $17,0 \%$ & $76,9 \%$ & $6,0 \%$ \\
\hline to finally move & 6 & 169 & 7 \\
abroad & $3,3 \%$ & $92,9 \%$ & $3,8 \%$ \\
\hline
\end{tabular}

Table 18: Distribution of planning to work abroad 
Among the goal countries those have priority where someone from their family, or close relatives work, respondents named England, Switzerland, Germany and Italy, the only surprise - since it is not a goal country of massive migration - is Canada.

It is important to say, that probably willingness to go abroad - even if only with the purpose of working - would have been higher if only household heads would have been asked, or even if only males would've been asked, since they are much mobile than females. Fathers working for months abroad, and mothers are taking care of children and the household, is still a common family structure in Moldova.

Regarding whether they would like to move, following answers were given.

\begin{tabular}{l|rrrrr} 
N=182 & very much & more yes & more no & not at all & doesn't know \\
\hline other locality in the county & 2 & 5 & 6 & 163 & 6 \\
& $1,1 \%$ & $2,7 \%$ & $3,3 \%$ & $89,6 \%$ & $3,3 \%$ \\
\hline other county of Moldova & 2 & 2 & 7 & 166 & 5 \\
& $1,1 \%$ & $1,1 \%$ & $3,8 \%$ & $91,2 \%$ & $2,7 \%$ \\
\hline Transylvania & 2 & 4 & 7 & 164 & 5 \\
& $1,1 \%$ & $2,2 \%$ & $3,8 \%$ & $90,1 \%$ & $2,7 \%$ \\
\hline other regions of Romania & 2 & 4 & 8 & 163 & 5 \\
& $1,1 \%$ & $2,2 \%$ & $4,4 \%$ & 89,6 & 2,7 \\
\hline Hungary & 6 & 3 & 7 & 161 & 5 \\
& $3,3 \%$ & $1,6 \%$ & $3,8 \%$ & $88,5 \%$ & $2,7 \%$ \\
\hline West Europe & 4 & 4 & 5 & 165 & 4 \\
& $2,2 \%$ & $2,2 \%$ & $2,7 \%$ & $90,7 \%$ & $2,2 \%$ \\
\hline Other & 4 & 3 & 5 & 166 & 4 \\
& $2,2 \%$ & $1,6 \%$ & $2,7 \%$ & $91,2 \%$ & $2,2 \%$ \\
\hline
\end{tabular}

\section{Table 19: Distribution of the likeliness of mooving abroad}

So what are the factors defining and as such ensuring elite position to a Csángó? Whether hypotheses were answered or denied it can be said that being highly involved in the Csángó matter helps but is not enough just like participating in migration is useful but does not ensure elite nomination. Elites are fulfilling the roles of opinion leaders and opinion brokers but they are not the only ones who do so, formal and informal leaders of major organizations are also possessing social capital efficiently used in the Csángó matter. Even if the Csángó matter is not understood in the most negative meaning of the Csángó business it needs to be acknowledged that some participant organizations and foundations are in competition and competition stands not only among groups but among individuals, among elites as well. Migrational experiences do have a positive effect on the odds of being named as elites but are no preconditions of it. Elites do have migration experiences but is not simply that what ensures them elite position is rather their way of living and mostly activity in the life of the community. While activity and 
key position in the everyday life of the community and the Csángó matter has a direct effect on the elite nomination migration seem to have a direct effect on these activities and as such an indirect effect on elite nominations as well. This observation is even more accentuated in the case of those who were enrolled in migration with the goal of studying in Transylvania and in Hungary. Statistical investigation did not bring any significant results to the hypothesis for whom is more important activity in the Csángó matter and without deciding interviews seem to underline that in the case of Csángós settled in Hungary - because of the sense of duty and pangs of consciousness for living other behind - activity is more important, on the other hand those in Moldova can and are more active.

These and similar uncertain topics are impossible to be answered in percantages, significances and statistics; qualitative data with quantitative supervision seemed the only operational data gathering and interpretation. By using interviews, social network and questionnaires in parallel and complementary succeeded in drawing the heterogeneity of the Csángó elite. 


\section{Conclusion and further investigation directions}

Arens and Bein point out that Moldva is still one of the less developed regions of Europe. The authors see the underdevelopment in political culture and mentality, economic aspects, infrastructure and several fields of the everyday life. Considering that the 1989 regime change did not reduce the distance toward west and there are two questions that are still open: first the situation of those Csángós, who are not yet assimilated. The question refers to their development and the confrontation - which due to the information society is more obvious and stronger than ever, regarding the origin and identity issues - with the already assimilated Csángós, just as with the laic and clerical elite. Second question listed is their fitting to the majority Orthodox society. (Arens \& Bein, 2004: 130) Taking further these questions one could ask how can (if they can) Catholics from Moldova fit in the Orthodox society and what happens with those who are Catholic and keep their ethnic minority, Hungarian culture and status, as well. How can they assert their interest and will they be in conflict or cooperation with the community and the society they are living in? Advocacy is often made by elites, but what happens if a society is seen and spoken of as having no elites, no intellectuals? Is that so indeed? Who are those to fulfill these roles and these positions?

At the beginning of this investigation I had a very firm hypothesis namely that the primary elite group is to be formed by those current or former migrants who are the key figures in the migration channels in the transmission of labor force from Moldova to other countries and the transmission of information. I assumed that from each village, or at least neighboring villages, networks are built to sustain guest working chains. I also assumed that migrants who left the village with the purpose of education and settled in other regions and countries are likely to be seen as elites yet their odds are lower, simply for not being present in the everyday life of the community. One might say that I couldn't be more wrong, or more right in the same time. As the investigation followed its course it became more and more clear that the Csángó elite - just as the Csángó community can't be described as a homogeneous group. The observation of Halász, the “total lack of stratification by wealth" (Halász, 2002:142) seems less and less valid.

The definition of the elite concept, the characterization of the members, the expectations toward the elite as a group and as individuals as well differs from respondent to respondent. Trying to find a common characteristic that can be found in all, or at least in the majority of the elite members is if not impossible than least to say 
very difficult or forced. Observation and data clarified that the composition of the group is different based on who is asked. Difference doesn't only concern individuals but also aspects, characteristics based on which, one considers someone elite.

Actors of this investigation - or at least several of them - have a sense of duty, a sense of obligation, a sense of mission toward the emissive community, in narrow meaning the village they are originating from, in broader sense toward the entire Csángó community. Being a minority, activity aiming to propagate their culture, customs and identity - the so called Csángó matter - has a significant role and most active, most talented in some or more aspects, the most eminent are seen by others or by themselves as "Csángó elites". There is a great insecurity in these "Csángó elites" regarding their position in the emissive society, their perception by the community. They are searching for a confirmation from the community that proves not only their ideas about what is the right path for the Csángó minority but also ratification in their position as elites. The ambivalent relation among elites and community is originating from not having a common Csángó consciousness, community knowledge. The community image seen by outsiders is created, built up and mostly sustained too, by ethnographers. Csángós do not identify themselves with this community image, so activism in the preservation of this image by elites is not always appreciated and/or considered important by the community as well.

Ethnicity and language hasn't been always so important as it is today. As it concerns identity and self identification one can use several factors, and one can use these indicators consequently or in parallel, without being insincere, inconsistent, etc. 100-150 years ago material situation defined ones identity and place and role in the society. Religion also made a great difference and other factors could be enumerated as well. As language got important, interethnic problems, the language of religious rituals received a greater attention on local and political level as well. One could argue that while religious rituals were held in Latin, habitants of "Csángó villages" could not understand more than when the language changed to Romanian. It was important to attend masses, to receive the sacraments, and whether the priest was speaking in Latin, Romanian or Hungarian was secondary the least to say. Similarly, saying that there were/are "Csángó villages" is a bit of an overstatement, either because the "Csángó" aspect had no importance, or because its habitants considered the locality as a Catholic village near the Orthodox majority villages, or because being from a Csángó village was something to hide, not to be proud of simply for being different, being a minority or 
because later on, when the minority situation became more acceptable, due to migrating not only from villages to towns but all over Europe and even further, identification steps on another level. On one hand Csángós found out, that belonging to a certain nation, being Hungarian can be something to be proud of instead of denying, being ashamed of. Defining themselves as Romanians in different parts of Europe is a much easier option than explaining that they are a minority in Romania yet just as much sustaining their Hungarian identity can be more advantageous in those countries where there is a negative attitude and stereotype towards Romanians. In a future Romanian and Hungarain self-identification can reach together when for example migrants strenghtened in their identity, return and start a business together and realize that ethnicity and ethnic identification can be used as an asset, as a resource and jointly is much more advantageous. It might be obvious that identity in the case of Csángós is not a closed and sealed topic, and as identity can be used as a resource - not only by attracting couple tourists - but by community engagement with others. Especially because ethnic identity can be considered and used as a capital, the expansion of Romanian assimilation is not, and should not be seen as much dynamic and irreversible than the undertaking of Hungarian identity.

The topic of the Csángó matter and Csángó elite is not the problem of Csángós solely, is a topic strongly influenced by national and political identity and affiliation. Csángós being at the intersection of Hungarian and Romanian culture, and geographically present in both countries their situation and their concerns should interest not only Csángó activists and elites, but politicians of the two countries and the European Union. Twenty years after the regime change it can be said that all three levels - the local, national and European - with different interest and force are all present and active.

The Csángó elite expressing interest in the Csángó matter is the same as the responsible intellectual category applicable 100 years ago, when the intellectual was someone who had the role and the goal of leading the community he/she is representing. The position of higher principles, in debates having the knowledge of the supreme truth is what an intellectual is and where he stood at the end of the $19^{\text {th }}$ beginning of the $20^{\text {th }}$ century.

Today the intellectual and the elite is differently interpreted and valued. Someone(s) knowing the truth, the only truth is not accepted as not only the society is plural but the interpretation of it as well. Yet in the case of Csángós, the elite - formed 
by the snowball sampling - wishes to fulfill the leading position of the community on the road that is considered the only that is beneficial for the community. Interviewees speak about the need of having a group of people who are able to think, research and write individually and independently. In order to speak bout Csángó elites a group of Csángós are needed who have intellectual increment. It is important to see that the demanded requirements to speak about elites are specific to the intellectual category rather the elite. While the elite defines themselves and the group according to roles and expectations characterizing the mentioned responsible intellectual, the community represented by the questionnaires collected in one village - operates on a different system of requirements. The community defines elites along material characteristics. It is interesting that the elite concept used by the community is much closer to the elite concept appearing in the social scientific literature. The elite interpretation of the community is much more applicable, much more consistent with reality than the elite interpretation of intellectuals of the elite itself. While there are two different elite definitions with different expectations and requirements the elite group formed by the snowball sampling - that is elite formed according to the characteristics of the elite - is to some extent confirmed by the community as well. Not accepting only confirmation, it can be observed that in the elite group "seen" by the community, intellectual actors are only at the periphery. For the village high prestige is directing to those materially well situated, successful members of the community who can show results locally. They are the same people who mean useful connections, who are helpful acquaintances.

The composition of the elite is not only different based on whether its definition is made by the community or by the elite, but it also differs according to the location of the respondent. While priests seem to be the group of elite recognized as such by elites and by the community as well, other elites are strongly criticizing the ethnic identification of priests as factor that makes impossible their definition as elites. Slightly apart from their Romanian self identification it can be said that the clerical elite is the most certain group of intellectuals and elites in Csángó villages and probably the only with several generations. Always present in the leading of the community, other groups and individuals gained importance and validity. In several cases their legitimation, their recognition as elites is often questioned, yet discussing their role in the Csángó society and their adjudication is indispensable.

The observation of Herzfeld about how "monumentalizing the past" (Herzfeld, 2000:234) gives a channel to preserve their position and power, can be used in the case 
of the csángó elite who are using the past and cultural element of the past as capital, as legitimation forms.

Representatives of the Csángó culture - artists, writers, singers, musicians, etc known by many people in Hungary are not necessarily recognized and appreciated in Moldova as well. Situation is more aggravated if the elite lives in Hungary. Several interviewees sustain that for the community is much more beneficial a locally present, educated (for example a teacher) person and his/her career than a much brighter career in Budapest. The group of local educated people should be strengthened and supported in their work. The importance of locally being present in order to be considered as elites applies to any sort of migration, regardless if they left to work or to study. If one is building career in Romania but not in Moldova is just as much not serving the interests of the Csángó village as one would be living much further. Interviewees acknowledge that it helps, because the Csángó consciousness and solidarity is very strong in those who live in Budapest, and they form a strong lobbying power. Interviewees agree that all Csángós - regardless of residence - have the duty to do everything for their community, and to represent them as well as possible, but the elite first of all needs to be strengthened in Moldova. To be seen as elite in the village, one has to be locally present, to live in the village or to keep regular contact with the local community by organizing different events.

Accepting geographical duality of the elite, generational aspects should be taken in consideration too. Future investigations should answer questions like what happens with the children of the elite and mostly what happens with children of elites situated in Hungary? Speaking about the lobbying power of the elite members settled in Hungary one could easily argue that the so called first generation can fulfill its role from Hungary, but will their children also be active members of the Csángó society or they will be integrated in the majority society?

Geographic settlement and ethnic identification of the Csángó elite shows a colorful picture, but what exactly ensures someone the elite position was one of the key concerns of this investigation. Like other minority elites, the Csángó elite is in a double difficult position. One difficulty is that as a member of a minority it is hard to be considered as elite on a national level, as elite of the majority society as well. This difficulty raises at least two observations namely that belonging to the national level should not be seen as a premise, locally one still can be seen as leader or elite, and national level is also a dual concept because in the case of the Csángó elite it can refer 
to Romania and to Hungary as well. The second difficulty is that by being geographically in two locations who is seen as elite by the community and by outsiders occasionally may differ. Roles of elites might also be different not just geographically but on affirmation and empirical level as well. As one interviewee pointed out:

"Én a faluhoz képest elit és értelmiségi is vagyok, miközben anyagi, meg társadalmi megbecsültségem sincs, mert itt elvegyülök a rengeteg költő meg kutató között, ott meg nem én vagyok az, akit megkeresnek ha baj van, hanem a pap. Mert én ma ott vagyok, holnap összecsomagolok, magukra maradnak. Ott ezeket a származékaimat, hogy értelmiségi, vagy elit nem tudom ... én nem érzem magam annak, tanult ember vagyok, mint a helyi tanár, itt pedig a szakmán belül mérem magam. „254 (36-50 years old employee living in Hungary)

Then again, what exactly provides the elite position to someone? According to the elite definition given by interviewees - themselves members of the elite and/or active participants of the Csángó matter - is the duty toward the community and the preservation of the interests of the community what matters the most in order to name consider someone elite. Based on the three diagrams and interviews an option palette was formulated on how one can have central position in the Csángó matter. In-Degree proved that being in a leading position at the MCSMSZ ensures high centrality. Being active in only one region does not seem enough one has to participate in events and organizational work in Moldova and Hungary as well. For those living in Hungary involvement in events organized in Moldova is even more important otherwise they will be exclusively named only by others from Hungary. Activity cannot be restrained to only one event or one organization. Bringing in social capital under the form of alters connected to the Csángó matter only to one actor, ensures him/her central position. Fulfilling the role of opinion leader or broker, bridging regions or groups is also of high benefits

There isn't one homogeneous elite group that can and is representing elites and the conflict situation among groups and organizations aiming to bring off their own ideas and goals should be handled with the decentralization of power, by building several bases which are more or less independent rather than searching for someone "perfect" to represent and to lead the Csángó matter. In 2012 a cooperation was initiated involving

\footnotetext{
${ }^{254}$ Compared to the village I am elite and intellectual, yet in the meanwhile I don't have material or social recognition, because here (Budapest) I mingle among the many poets and researchers, and there (Moldova) I am not the one they search in the case of need, but the priest. Because today I am there, tomorrow I pack, they are on their own. There, these derivates, like intellectual or elite, I don't know ... I don't feel as such, I am an educated person, just like the local teacher, here I measure myself within the proffesion.
} 
three organizations - instead of the previously almost monopoly situation of the MCSMSZ - that now formally bring decisions regarding the Hungarian teaching in Moldova. Nugent shows that in the case of Amazonian elites, previous elites were foreigners "imports, in the form of church, military and colonial personnel". (Nugent, 2002:64). These are the antecedents of the Csángó elite as well and whether the changes just introduced will solve the conflict - often seen as the conflict among Csángós in Moldova and Csángós in Hungary just as the conflict of non-Csángó activists from Moldova and Csángós from Hungary - and manage to develop a cooperative and purposeful Csángó elite or will deepen the influence of "foreign elites" is the question of future investigations to answer. 


\section{Bibliography}

[ILO], I. L. O., 1973. Migration of Workers as an Element in Employment Policy, December..

Adler-Lomnitz, L., 1975. Cómo sobreviven los marginados. Mexico: Siglo XXI.

Adler-Lomnitz, L. \& Gonzalez, A. N., 2007. Peasant ethnic migration from a postcommunist society to another. The case of the Csángó migrants from Moldavia (Romania) to Hungary. Review of Sociology, Vol 13.1., pp. 67-88.

Alba, D. R. \& Moore, G., 1978. Elite Social Circles. Sociological Methods \& Research, pp. 167-188.

Anon., 2007. Almanahul Presa Bună. Iași: Presa Bună.

Arens, M. \& Bein, D., 2004. Katolikus magyarok Moldvában. In: A. (. Miskolczy, szerk. Rendhagyó nézetek a csángókról. Budapest: ELTE Román Filológiai Tanszék - A Központi Statisztika Hivatal Levéltára, pp. 11-91.

Babits, M., 1928. Az írástudók árulása. Nyugat 18.

Bailey, N., 1975. The Mathematical Theory of Infectious Disease and Its Applications. London: Charles Griffin.

Baker, R., 1997. On the Origin of the Moldavian Csángós. The Slavonic and East European Review, pp. 658-680.

Bandinus, M., 1987. Codex Bandinus (1646-1648). In: A moldvai magyarság. Budapest: Magvető Kiadó, pp. 334-479.

Barnes, J. A., 1954. Barnes, J. A. Class and Committees in a Norwegian Island Parish. Human Relations, pp. 39-58.

Barnes, J. A., 1987. This Week's Citation Classic. Current Contents, 8 June, p. 18.

Baucic, I., 1974. Some economic consequences of Yugoslav external migrations. Paper presented at the Colloque sur les Travailleurs Immigres en Europe Occidentale, Paris, June 5-7.

Becker, G., 1993 (1964) . Human Capital: A Theoretical and Empirical Analysis, with Special Reference to Education.. Chicago: University of Chicago Press.

Benda, K., 1989. A moldvai magyarok (csángók) a XVI. XVII. században.. In: Moldvai csángó-magyar okmánytár 1467 - 1706. Budapest: Magyarságkutató Intézet, pp. 9-51.

Benkő, L., 1990. A csángók eredete és települése a nyelvtudomány szemszögéböl. Budapest: A Magyar Nyelvtudományi Társaság Kiadványai 188.

Bíró, A. Z., 2002. "Csúcsok" és hétköznapok. Szempontok a magyar-magyar reláció társadalomtudományi elemzéséhez. In: Magyarország és a magyar kisebbségek (történeti és mai tendenciák). Budapest: MTA, pp. 135-144.

Boissevain, J. e. a., 1990. Ethnic entrepreneurs and Ethnic Strategies. In: R. Waldinger, H. Aldrich \& R. Ward, szerk. Ethnic Entrepreneurs. London: Sage Publications, p. 131-57.

Bott, E., 1957. Family and Scoial Network: Roles, Norms, and External Relationships in Oridnary Urban Families. London: Tavistock. 
Bottomore, T., 1993 (1964). Élites and society. London: Routledge.

Bourdieu, P., 1986. The Forms of Capital. In: Handbook of Theory and Research for the Sociology of Education. New York : Greenwood Press, pp. 241-258.

Bourdieu, P., 2002. A mezők logikája. In: Szociológiai irányzatok a XX. században. Budapest: Új Mandátum, pp. 418-430.

Boyd, M., Autumn, 1989. Family and Personal Networks in International Migration: Recent Developments and New Agendas. International Migration Review, Vol. 23, No. 3, Special Silver Anniversary Issue: International Migration an Assessment for the 90's, pp. 638-670.

Brown, L., 1981. Innovation Diffusion: A New Perspective. New York: Methuen.

Brubaker, R., Feischmidt, M., Fox, J. \& Grancea, L., 2006. Nationalist Politics and Everyday Ethnicity in a Transylvanian Town.. Princeton: Princeton University Press.

Burt, R. S., 1987. Social Contagion and Innovation: Cohesion Versus Structural Equivalence. The American Journal of Sociology, Vol. 92, No. 6., pp. pp. 12871335.

Burt, R. S., 2001. The Social Capital of Structural Holes. In: New Directions in Economic Sociology. New York: Russell Sage Foundation, pp. 202-250.

Burt, R. S., 2002. The Social Capital of Structural Holes. In: The New Economic Sociology : Developments in an Emerging Field. New York: Russell Sage Foundation, pp. 148-190.

Cammack, P., 1990. A Critical Assessment of the New Elite Paradigm. Sociological Review, pp. pp.415-420.

Castles, S., 1994. How nation-states respond to immigration and ethnic diversity. New Community.

Christakis, N. A. \& Fowler, J. H., 2010. Kapcsolatok hálójában. Mire képesek a közösségi hülózatok és hogyan alakitják sorsunkat?. Budapest: Typotex.

Cohen, A., 1981. The politics of elite culture: explorations in the dramaturgy of power in a modern African society. Berkley, CA: University of California Press.

Coleman, D. A., 1995. International Migration: Demographic and Socioeconomic Consequences in the United Kingdom and Europe. International Migration Review. Special Issue: Diversity and Comparability: International Migrants in Host Countries on Four Continets.

Coleman, D. A., 1995. International Migration: Demographic and Socioeconomic Consequences in the United Kingdom and Europe. International Migration Review, Vol. 29, No. 1, Special Issue: Diversity and Comparability: International Migrants in Host Countries on Four Continets.

Coleman, J. S., 1988. Social Capital in the Creation of Human Capital. American Journal of Sociology, Vol. 94, Supplement: Organizations and Institutions: Sociological and Economic Approaches to the Analysis of Social Structure, pp. S95-S120.

Coleman, J. S., Katz, E. \& Menzel, H., 1966. Medical innovation: A diffusion study. New York: Bobbs Merrill. 
Cosa, A., 2007. Catolicii din moldova în izvoarele sfântului scaun (secolele XVIIXVIII). Iaşi: Sapientia.

Costenbader, E. \& Valente, T., 2003. The stability of centrality measures when networks are sampled.. Social Networks., pp. 283-307.

Csata, Z. \& Kiss, T., 2003/2. Migrációs potenciál Erdélyben. Erdélyi Társadalom , pp. 7-38.

Dahl, A. R., 1961. Who Governs? Democracy and Power in an American City. New Haven, Connecticut: Yale University Press.

Demse, M., 2007. Somoskai tél. Kézdivásárhely: Zelegor.

Dexter, L., 1970. Elite and specialized interviewing. Evanston, UL: Northwestern University Press.

Diaconescu, M., 2005. A moldvai katolikusok identitáskrízise a politika és a hstoriográfiai mítoszok között. In: Adaptáció és modernizáció a moldvai csángó falvakban. Kolozsvár: Kriza János Néprajzi Társaság, pp. 9-21.

Diószegi, L., 2006. A moldvai csángók. Veszélyeztetett örökség-veszélyeztetett kisebbségek. Budapest: Teleki László Alapítvány.

Domokos, P. P., 1931. A moldvai magyarság. Csíksomlyó: ismeretlen szerző

Domokos, P. P., 1979. ...édes Hazámnak akartam szolgálni.... Budapest: Szent István Társulat.

Domokos, P. P., 1987. A moldvai magyarság. Ötödik átdolgozott kiadás. Budapest: Magvető Kiadó.

Dövényi, Z., 1997. Adalékok a Magyarországon élö "idegenek" területi megoszlásához. In: Migráció és politika. Budapest: MTA PTI Nemzetközi Migráció Kutatócsoport Évkönyve 1996, pp. 97-105.

Etzioni-Halévy, E. e., 1997. Classes and Elites in Democracy and Democratization.. New York: Garland.

Eyal, G. \& Townsley, E., 1995. The Social Composition of the Communist Nomenklatura: A Comparison of Russia, Poland, and Hungary. Theory and Society. Special Issue on Circulation vs. Reproduction of Elites during the Postcommunist Transformation of Eastern Europe, pp. 723-750.

Fawcett, J. T., 1989. Networks, Linkages and Migration Systems. International Migration Review.Special Silver Anniversary Issue: International Migration an Assessment for the 90's.

Feld, S. L., 1981. The Focused Organization of Social Ties. The American Journal of Sociology, Vol. 86, No. 5 , pp. 1015-1035.

Felkai, P., Némedi, D. \& Somlai, P. (., 2000. Szociológiai irányzatok a XX. században. Budapest: Új Mandátum.

Ferenc, P., 2003. A moldvai Csángó-Magyar falvak társadalomszerkezete. Pro Minoritate., p. 142-165..

Fernandez, R. M. \& Gould, R. V., 1999. A dilemma of state power: brokerage and influence in the national health policy domain. The American Journal of Sociology, , pp. 1455 - 91. 
Fischer, M. M., 1986. Ethnicity and the Post-Modern Arts of Memory. In: Writing Culture. the Poetics and Politics of Ethnography. Berkley-Los Angeles-London: University of California Press, pp. 194-233.

Fodor, E., Wnuk-Lipinski, E. \& Yershova, N., 1995. The New Political and Cultural Elite. Theory and Society.Special Issue on Circulation versus Reproduction of Elites during the Postcommunist Transformation of Eastern Europe, pp. 783-800.

Freeman, L. C., 1977. A Set of Measures of Centrality. Based on Betweenness.. Sociometry Vol.40, No.1., pp. 35-40.

Fukuyama, F., 1995. Trust: The Social Virtues and the Creation of Prosperity. New York: Free Press.

Fukuyama, F., 1997. Social Capital. The Tanner Lectures on Human Values, http://www.tannerlectures.utah.edu/lectures/documents/Fukuyama98.pdf downloaded 2012.03.01: Delivered at Brasenose College, Oxford, May 12, 14, and 15, 1997.

Fumanti, M., 2004. The making of the fieldwork-er:debating agency in elites research. Anthropology Matters, Vol.6, No.2.

Gábor, F., 2008. Csángó vagyok. Csíkszereda: Hargita Kiadóhivatal.

Gagyi, J. \& Oláh, S., 1997. Vendégmunkások utazási formái Hargita megyéből Magyarországra. In: Migráció és politika MTA Politikai Tudományok Intézete. Nemzetközi Migráció Kutatócsoport Évkönyve 1996. Budapest: ismeretlen szerző

Gegö, E., 1987. A moldvai magyar telepekröl. Budapest. Budapest: ÁKV.

Gödri, I., 2004. Etnikai vagy gazdasági migráció? Az erdélyi magyarok kivándorlását meghatározó tényezők az ezredforulón. erdélyi Társadalom 2. évf., 1. szám, pp. $37-54$.

Gödri, I., 2007. A kapcsolati tőke szerepe a magyarországi bevándorlásban. Kisebbségkutatás, 16. évf, 4. sz., pp. 699-727.

Grabher, G. \& Stark, D., 1997. Organizing Diversity. Evolutionary Theory, Network Analysis and Postsocialism. Regional Studies, Vol.31.5, pp. 533-544.

Granovetter, M. S., 1973. The Strength of Weak Ties. American Journal of Sociology, Vol. 78, No. 6, pp. 1360-1380.

Greenwood, M. J., 1975. Research on International Migration in the United States: A Survey. Journal of Economic Literature.

Gunda, B., 1988. A moldvai magyarok eredete. Magyar nyelv 84, pp. 12-24.

Halász, P., 2002. Bokrétába kötögetem vala. A moldvai magyarok néprajzához. Budapest: Európai Folklór Intézet.

Hansen, J. \& Löfström, M., 2003. Immigrant Assimilation And Welfare Participation: Do Immigrants Assimilate Into Or Out Of Welfare?. The Journal of Human Resources Vol. 38, No. 1, pp. 74-98.

Harvey, P., 2002. Mestizo traders in the southern Peruvian Andes. In: Elite Cultures. Anthropological perspectives. London: ASA Monographs v.38, Routledge, pp. 74-90. 
Hegyeli, A., 1999. "Mint a gomba, ide benőttek ..." Moldvai csángók vendégmunkája Magyarországon. In: Csángósors. Moldvai csángók a változó világban. Budapest: Teleki László Alapítvány, pp. 163-173.

Hegyeli, A., 2005. Esettanulmány egy modern klézsei családról. In: Adaptáció és modernizáció a moldvai csángó falvakban. Kolozsvár: Kriza János Néprajzi Társaság, pp. 226-234.

Héra, G. \& Ligeti, G., 2006. Módszertan. Bevezetés a társadalmi jelenségek kutatásába. Budapest: Osiris Kiadó.

Herzfeld, M., 2000. Uncanny Success. Some Closing Remarks. In: Elites: Choice Leadership and Succession. Oxford: Berg.

Herzfeld, M., 2000. Uncanny success: some closing remarks. In: Elites: choice leadership and succession. Oxford: Berg.

Higley, J., Burton, M. \& Field, G. L., 1990. In Defense of Elite Theory: A reply to Cammack. American Sociological Review, pp. 421-426.

Higley, J. \& Burton, M. G., 1989. The Elite Variable in Democratic Transition and Breakdowns. American Sociological Review, pp. 17-32.

Higley, J. \& Gunther, R., 1992. Elites and Democratic Consolidation in Latin America and Southern Europe.. Cambridge: Cambridge University Press.

Higley, J. \& Moore, G., 1981. Elite Integration in the United States and Australia. The American Political Science Review, pp. 581-597.

Higley, J. \& Pakulski, J., 1998. Elitelmélet a marxizmus után. Századvég (Új folyam), 9 (nyár), pp. 71-88.

Horváth, I., 2002. A romániai magyar kisebbség Magyarországra irányuló mozgása. Korunk, 2. szám, pp. 31-47.

Iancu, L., 2006. Alternatíva vagy determináció? Töprengések a csángó értelmiség egyéni és közösségi szerepmeghatározottságáról. In: A moldvai csángók. Veszélyeztetett örökség-veszélyeztetett kisebbségek. Budapest: Teleki László Alapítvány, pp. 165-176.

Ilonszki, G., 2003/4. Számít-e az elit folytonossága?. Politikatudományi Szemle, pp. 109-124.

Iorga, N., 1928. Istori Romanilor prin calatori. Bucuresti: Editura Eminescu.

Iorga, N., 1993. Istoria românilor. III. Bucureşti: ismeretlen szerző

Isohookana-Asunmaa, T., 2001. A csángó kisebbségi kultúra Romániában. [Online] [Hozzáférés dátuma: 2707 2011].

Iyengar, R., Van de Bulte, C. \& Valente, T. W., 2011. Opinion Leadership and Social Contagion in New Product Diffusion. Marketing Science, vol. 30 no. 2 , pp. 195212.

Jerney, J., 1851. Jerney János keleti utazása a'Magyarok'öshelyeinek kinyomozása végett 1844 és 1845. I-II.. Pest: ismeretlen szerző

Kadushin, C., 1966. The Friends and Supporters of Psychoterapy: On Social Circles in Urban Life. American Sociological Review, pp. 786-802. 
Kadushin, C., 1968. Power, Influence and Social Circles: A new methodology for studying opinion makers. American Sociological Review, pp. 685-699.

Kadushin, C., 1972. Who are the elite intellectuals?. Public Interest No.29 Fall, pp. 109-125.

Kadushin, C., 1978. The Intelligensia and the Intellectuals by Aleksander Gella. Social Forces Vol.56 No. 4, pp. 1258-1259.

Kadushin, C., 1995. Friendship Among the French Financial Elite. American Sociological Review, pp. 202-221.

Kadushin, C., Hover, J. \& Tichy, M., 1971. How and where to find Intellectual elite in the United States. The Public Opinion Quarterly, pp. 1-18.

Karácsonyi, J., 1914. A moldvai csángók eredete. Századok, pp. 545-561.

Katz, E., 1957 Spring. The Two-Step Flow of Communication: An Up-To-Date Report on Hypothesis. The Public Opinion Quarterly, Vol. 21, No.2 Anniversary issue Devoted to twenty Years of Public opinion Research, pp. 61-78.

Katz, E. \& Lazarsfeld, P. F., 1955. Personal influence. Glencoe: Free Press.

Kezar, A., 2003. Transformational Elite Interviews: Principles and Problems. Qualitative Inquiry, pp. 395-415.

Kinda, I., 2005. A papi státus deszakralizációja a moldvai csángó falvakban. Székelyföld. Kulturális folyóirat IX. évf. 4. sz., pp. 133-145.

Kinda, I., 2006. A pap helye a lokális társadalom életében. In: Veszélyeztetett örökség, veszélyeztetett kultúrák. A moldvai csángók. Budapest: Teleki László Alapítvány, pp. 147-156.

Kinda, I., 2007. Büntető szokások a moldvai csángóknál. Erdélyi Társadalom 5.évf.2.sz., pp. 127-144.

Kinda, I. \& Pozsony, F., 2005. Adaptáció és modernizáció a moldvai csángó falvakban. Kolozsvár: Kriza János Néprajzi Társaság.

King, L. P. \& Szelényi, I., 2004. Theories of the New Class: Intellectuals and Power. Minneapolis - London: University of Minnesota Press.

Kolosi, T., 2000. A terhes babapiskóta. A rendszerváltás társadalomszerkezete.. Budapest: Osiris.

Konrád, G. \& Szelényi, I., 1979. The Intellectuals on the Road to Class Power. New York: Harcourt, Brace, Jovanovich.

Konrad, M., 2002. Pre-symptomatic networks. Tracking experts across medical science and the new genetics.. In: Elite cultures. Anthropological perspectives.. New York: ASA Monographs 38, pp. 227-248.

Lajos, V., 2006. Modernizáció és társadalom a moldvai csángó közösségekben: kérdésfeltevések a migráció témakörben. In: Veszélyeztetett örökség, veszélyeztetett kultúrák. A moldvai csángók. Budapest: teleki lászló Alapítvány, pp. 177-184.

Lasswell, H. D., 1936. Politics: Who Gets What, When How. New York: McGraw-Hill. 
Latkin, C. és mtsai., 1996. Behavioral settings and personal network characteristics as correlates of needle sharing. Journal Of Acquired Immune Deficiency Syndromes And Human Retrovirology 13 (3), pp. 273-280.

Le Calloc'H, B., 2005. Les Csángós de Moldavie. Brest: Éditions Armeline.

Lee, R. M., 1993. Doing research in sensitive topics. London-Newbury Par-New Delhi: Sage Publications.

Letenyei, L., 2002. Helyhez kötött kapcsolatok. Egy társadalmi kapcsolathálókon alapuló magyarázat a földrajzi munkamegosztás kialakulására. Közgazdasági Szemle, p. 875-888.

Letenyei, L., 2005. Településkutatás. Budapest: L'Harmattan.

Levitt, P. \& Glick Schiller, N., Fall, 2004. Conceptualizing Simultaneity: A Transnational Social Field Perspective on Society. International Migration Review, Vol. 38, No. 3, Conceptual and Methodological, pp. 1002-1039.

Lilleker, D. G., 2003. Interviewing the Political Elite: Navigating a Potential Minefield. Politics Vol 23(3), p. 207-214.

Lin, N., 1999. Building a Network Theory of Social Capital'. Connections 22(1), pp. 28 51.

Lotter, S., 2004. Chris Shore\&Stephen Nugent (eds). Elite cultures: anthropological perspectives. ASA Monographs No.38. London: Routledge, 2002. Anthropology Matters, Vol. 6, No.1.

Lotter, S., 2004. Studying-up those who fell down: elite transformation in Nepal. Anthropology Matters, Vol. 6, No. 2.

Lubbers, M. J., Molina, J. L. \& McCarty, C., 2007. Personal Networks and Ethnic Identifications. The Case of Migrants in Spain. nternational Sociology December vol. 22 no. 6 , pp. 721-741.

Lucassen, L., 1991. The Power of Definitions. Stigmatization. The Netherlands Journal of Social Sciences, 27 (2), pp. 80-91.

Lükő, G., 1936. Moldva alapításának mondáihoz. Ethnographia. XLVII., no.1-2, pp. 4856.

Lükő, G., 2002. A moldvai csángók. I. A csángók kapcsolatai az erdélyi magyarsággal. Veszprém: OOK-Press.

Lükő, G., 2008. Bibliotheca Moldaviensis. Csíkszereda - Miercurea Ciuc: Harghita Kiadóhivatal - Editura Harghita.

Marcus, G., 1983. Elites: Ethnographic Issues. Albuquerque, NM: University of New Mexico Press.

Marsden, P. V., 1987. Core Discussion Networks of Americans. American Sociological Review, pp. 122-131.

Mărtinaş, D., 1985. Originea ceangăilor din Moldova. Bucureşti: Editura Ştiinţifică şi enciclopedică.

Marx, K. \& Engels, F., 2004. The German Ideology.Part oen with selections from part two and three and supplementary texts.. New York: International Publishers Co.. 
Massey, D. S. e. a., 1987. Return to Aztaln: the Social Process of International Migration from Western Mexico. Berkley and Los Angeles: University of California Press.

Massey, D. S. e. a., 1998. Worlds in motion. understanding International Migration at the end of the Millenium. Oxford: Clarendon Press.

McCarty, C., Molina, J. L., Aguilar, C. \& Rota, L., 2007 May. A Comparison of Social Network Mapping and Personal Network Visualization. Field Methods Vol. 19, No. 2, p. 145-162.

Menzel, H. \& Katz, E., 1955-1956. Social Relations and Innovation in the Medical Profession: The Epidemiology of a New Drug. The Public Opinion Quarterly, Vol. 19, No. 4., pp. 337-352.

Mikecs, L., 1989. Csángók. Pécs: Bolyai Akadémia.

Milgram, S., 1967. The Small-World Problem. Psychology Today, vol. 1, no. 1, pp. 6167.

Mills, C. W., 1962. Az uralkodó elit. Budapest: Gondolat Kiadó.

Mitchell, C., 1969. Social Networks in urban Situations: Analysis of personal Relationships in central Towns. Manchester: Manchester University Press.

Mohácsek, M. \& Vitos, K., 2005. Migráció és településfejlődés. A magyarfalusi vendégmunkások fogyasztói szokásai. In: Adaptáció és modernizáció a moldvai csángó falvakban. Kolozsvár: Kriza János Néprajzi Társaság.

Moreno, J. L., 1953 (1934). Who Shall Survive?: Foundations of Sociometry, Group Psychotherapy, and Sociodrama. Beacon, NY: Beacon House Inc.

Morris, M., 1993. Epidemiology and social networks: modeling structured difusion. Sociological Methods and Research, pp. 99-126.

Mosca, G., 1939. The Ruling Class. New York: McGraw-Hill Inc..

Munkácsi, B., 1902. A moldvai csángók eredete. Ethnográfia, pp. 433-440.

Nader, L., 1972. Up the anthropologist - perspectives gained from studying up. In: Reinventing anthropology. New York: Random House.

Nugent, S., 2002. Gente boa. Elites in and of Amazonia. In: Elite Cultures. Anthropological perspectives. London: ASA Monographs v.38, Routledge, pp. 61-73.

Obstfeld, D., 2005. Social Networks, the Tertius Iungens Orientation, and Involvement in Innovation. Administrative Science Quarterly Vol. 50, No. 1, pp. 100-130.

Odendahl, T. \& Shaw, A. M., 2001. Interviewing elites. In: Handbook of Interview Research: Context \& Method. Thousand Oaks - London - New Delhi: Sage Publications, p. 305.

Pakulski, J. \& Waters, M., 1996. The Reshaping and Dissolution of Social Class in Advanced Society. Theory and Society, pp. 667-691.

Papademetriou, D. G., 1978. European Labor Migration. Consequences for the Countries of Worker Origin. International Studies Quarterly.

Pareto, V., 1963. A Treatise on General Sociology. New York: Dover Publications. 
Patton, M. Q., 1990. Qualitative Evaluation and Research Methods. Sage Publications: London.

Portes, A., 1994. Introduction: Immigration and Its Aftermath. International Migration Review. Special Issue: The New Second Generation.

Portes, A., 1996. Global Villangers: The Rise of Transnational Communities. [Online] [Hozzáférés dátuma: 2810 2011].

Portes, A., 1997. Globalizing from below: The Rise of Transnational Communities. NJ: Prinecton University Press.

Portes, A., 2000. An Enduring Vision: The Melting Pot that Did Happen. International Migration Review.

Portes, A. \& Böröcz, J., 2001. Keserü kenyér: a munkaerő nemzetközi migrációjának szociológiai problémái. In: A migráció szociológiája. Budapest: Szociális és Családügyi Minisztérium, p. 69-88.

Pozsony, F., 2002. Ceangăii din Moldova. Cluj: Asociația Etnografică Kriza János.

Pozsony, F., 2002. Church life in moldavian Hungarian communities. In: Hungarian Csángós in Moldavia. Essays on the Past and Present of the Hungarian Csángós in Moldavia. Budapest: teleki lászló Foundation - Pro Minoritate Foundation, pp. 83-115.

Pozsony, F., 2003. A moldvai Csángó-Magyar falvak társadalomszerkezete. Pro Minoritate, pp. 142-165.

Putnam, R. D., 1995. Bowling Alone: America's Declining Social Capital. Journal of Democracy 6(1), pp. 65-78..

Putnam, R. D., 2000. Bowling Alona. The Collapse and Revival of American Community. New York: Simon\&Schuster.

Radcliffe-Brown, A. R., 1940. On Social Structure. Journal of the Royal Anthropological Institute of Great Britain and Ireland, p. 188-204.

Râmneanțu, P., 1943. Grupele de sînge la ceangăii din Moldova. Buletin eugenic şi biopolitic, pp. 51-56.

Rogers, E. M., 2003. Diffusion of Innovations 5th edition. New York: Free Press.

Rogers, E. M. \& Cartano, D., 1962. Methods of measuring opinion leadership. Pyublic Opinion Quarterly 26, pp. 435-441.

Rogers, E. M. \& Kincaid, D. L., 1981. Communication Networks: Toward A New Paradigm for Research. New York: Free Press.

Rose, A. M., 1967. The Power Stucture. New York: Oxford Universtity Press.

Rosetti, R., 1905. Despre ungurii şi epicopiile catolice din Moldova. Analelel Academiei Române. Seria II. Tom. XXVII. Memoriile Secțiunii Istorice nr.10, pp. 247-322.

Rubinyi, M., 1901. A moldvai csángók múltja és jelene. Ethnographia XII, pp. 115-124, 166-175.

Rudas, T., 2006. Közvélemény-kutatás. Értelmezés és kritika. Budapest: Corvina.

Rustow, D. A., Jul., 1966. The Study of Elites: Who's Who, When, and How. World Politics, Vol. 18, No. 4., pp. 690-717. 
Ryan, R. \& Gross, N., 1943. The diffusion of hybrid seed corn in two Iowa communities. Rural Sociology 8(1), pp. 15-24.

Salt, J., 2001. Az európai migrációs térség. Régió 12. évf., 1. szám, pp. 177-212.

Sandu, D., 2005. Emerging Transnational Migration from Romanian Villages. Current Sociology.

Sandu, D., 2010. Lumile sociale ale migrației româneşti în străinătate. Iaşi: Polirom.

Schultz, T. W., 1961 March. Investment in Human Capital. The American Economic Review, Vol. 51, No.1., pp. 1-17.

Sebestyén, E., 1904. A romániai magyarok élete. A romániai magyarok történetéböl.. Budapest: Budapesti Hírlap Nyomdája.

Seidman, I., 2003. Az interjú, mint kvalitatív kutatási módszer. Budapest: Müszaki Könyvkiadó.

Sereno, R., 1962. The Rulers. New York: Praeger.

Shain, Y., Winter, 1999-2000. The Mexican-American Diaspora's Impact on Mexico. Political Science Quarterly, Vol.114, No. 4, pp. 661-691.

Shore, C. \& Nugent, S. (., 2002. Elite cultures: anthropological perspectives. London: ASA Monographs v.38, Routledge.

Sik, E., 1989. Az erdélyi menekültek. Az "Erdély" vizsgálat zárójelentése. Budapest: TÁRKI.

Sik, E., 2004. Mérhetetlen (ül fontos) tőkék.. In: Stabilizálódó társadalomszerkezet. Budapest: TÁRKI.

Simon, B., 2005. Hogyan "boldogulnak" a csángók? Az identitás kinyilvánításának versus elrejtésének stratégiái egy moldvai közösségben. Erdélyi társadalom. 3. évf. 1.szám, p. Kolozsvár.

Simon, B. \& Péter, L., 2004. Ha már egyszer csángó vagy, meg kell tanulj boldogulni" Egy moldvai falu lakóinak identitásépítő stratégiái. Pro Minoritate, Ösz-Tél, pp. 123-146.

Soysal, Y., 1994. Limits of Citizenship. Migrants and Postnational Membership in Europe. Chicago: The University of Chicago Press.

Spencer, J., 2002. The vanishing elite. The political and cultural work of nationalist revolution in Sri Lanka. In: Elite Cultures. Anthropological perspectives. New York: ASA Monographs 38, pp. 91-109.

Stark, O., 1984. 'Rural-to-urban migration in LDCs: a relative deprivation approach.' Economic. Economic Development and Cultural Change, vol. 32 (3),, pp. 475-86.

Stark, O. \& Taylor, J. E., 1989. Relative deprivation and international migration. Demography, vol. 26, pp. 1-14.

Stark, O. \& Taylor, J. E., 1991. Migration incentives, migration types: the role of relative deprivation. The Economic Journa.

Sylveszter, L., dátum nélk. Csupa csapás az élet. Az elsorvadt moldvai magyar oktatás és a csángó szétrajzások emlékkönyve..

Szántó, Z. \& Tóth, I. G., 1993. A társadalmi hálózatok elemzése.. Társadalom és gazdaság, pp. 31-55. 
Tampu, K., 2010. Egyház és társadalom a moldvai csángók körében a XVII. században. A moldvai katolikus egyház a XVII. század derekán ahogy a hittéritök látták (1640-1660). Manuscript: ELTE BTK.

Tánczos, V., 1997. Hányan vannak a moldvai csángók?. Magyar Kisebbség, pp. 370390.

Tánczos, V., 2001. Moldvai csángók - moldvai katolikusok. Lélekszámuk alakulása a múltban és a jelenben. Ethnographia, pp. 149-178.

Tánczos, V., 2001. Szappan a kredenc sarkán, avagy a csángókérdés tudománya és politikája. Kisebbségkutatás, pp. 53-62.

Tánczos, V., 2008. Lükő Gábor csángó települéströténeti adattára. In: Bibliotheca Moldaviensis. Csíkszereda - Miercurea Ciuc: Harghita Kiadóhivatal - Editura Harghita.

Thomas, W. I. \& Znaniecki, F., 1918-1920. The Polish Peasent in Europe and America. Chicago: the University of Chicago Press.

Thomas, W. I. \& Znaniecki, F., 2002-2004. A lengyel paraszt Európában és Amerikában. Budapest: Új Mandátum.

Tilly, C. \& Brown, C. H., 1967. On Uprooting, Kinship, and the Auspices of Migration. International Journal of Comparative Sociology no.8., pp. 139-164.

Tismăneanu, V., 2006. Comisia Prezidențială pentru Analiza Dictaturii Comuniste din România,

http://www.presidency.ro/static/ordine/RAPORT_FINAL_CPADCR.pdf: ismeretlen szerző

Tóth, P. P., 2003. Nemzetközi vándorlás - magyar sajátosságok. Demográfia, XLVI. évf. 4. szám, pp. 332-340.

Valente, T. W., 1995. Network Models of the Diffusion of Innovations. New Jersey: Hampton Press.

Valente, T. W., Watkins, S. C., Jato, M. N. \& VanderStraten, A., 1997. Social network associations with contraceptive use among Cameroonian women in voluntary associations. Social Science \& Medicine, pp. 677-687.

Waldinger, R., Aldrich, H. \& Ward, R., 1990. Ethnic Entrepreneurs. London: Sage Publications.

Wallace, C., Chmouliar, O. \& Sidorenko, E., 1996. The Eastern frontier of Western Europe: mobility in the buffer zone. New Community, Vol.22, No.2, April, pp. 259-286.

Weigand, G., 1902. Fremde Elemente in der Moldau.. Neuter Jahresbericht des Instituts für Rumänische Sprache zu Leipzig., pp. 138-236.

Wellman, B., 2000. Networking Network Analysts: How INSNA (the International Network for Social Network Analysis) Came to Be. Connections, pp. 20-31.

Whyte, W. F., 1984. Learning from the field. Beverly Hills, CA: Sage.

Wright, E. O., 1996. The Continuing Relevance of Class Analysis-Comments. Theory and Society, pp. 693-716. 


\section{Annexes}

\subsection{List of abbreviations}

$\begin{array}{ll}\text { MCSMSZ } & \begin{array}{l}\text { Moldvai Csángó Magyarok Szövetsége (Association of } \\ \text { Csángó Hungarians in Moldova) } \\ \text { KEMCSE }\end{array} \\ & \text { A Keresztszülők a Moldvai Csángó Magyarokért } \\ & \text { Egyesület (The Godparents for the Moldavian Csángó } \\ & \text { Hungarians Association) } \\ & \text { A Moldvai Magyar Oktatásért Alapítvány (Foundation for } \\ \text { AMMOA } & \text { the Hungarian Education in Moldova) } \\ \text { NEI } & \text { International Preparatory Institute } \\ \text { Magyar Népi Mozgalom } & \text { (The Hungarian Populist Movement) } \\ \text { Táncház } & \text { Dance house }\end{array}$




\subsection{Romanian migrations patterns}

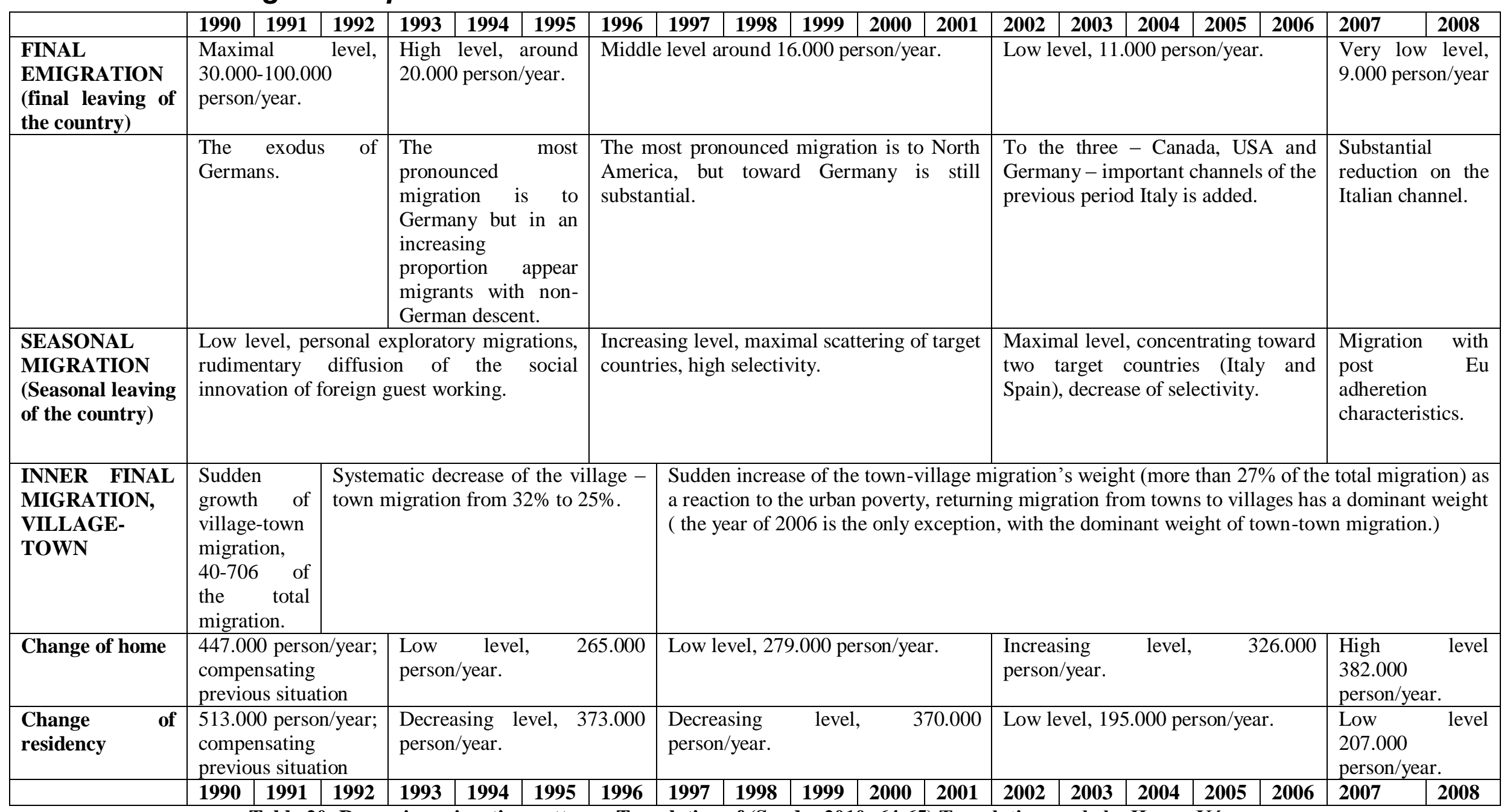

Table 20: Romanian migration patterns. Translation of (Sandu, 2010: 64-65) Translation made by Hanna Kónya. 


\subsection{Main Regions of External Circular Migration from Romanian Rural Population, (Sandu, 2005:563)}

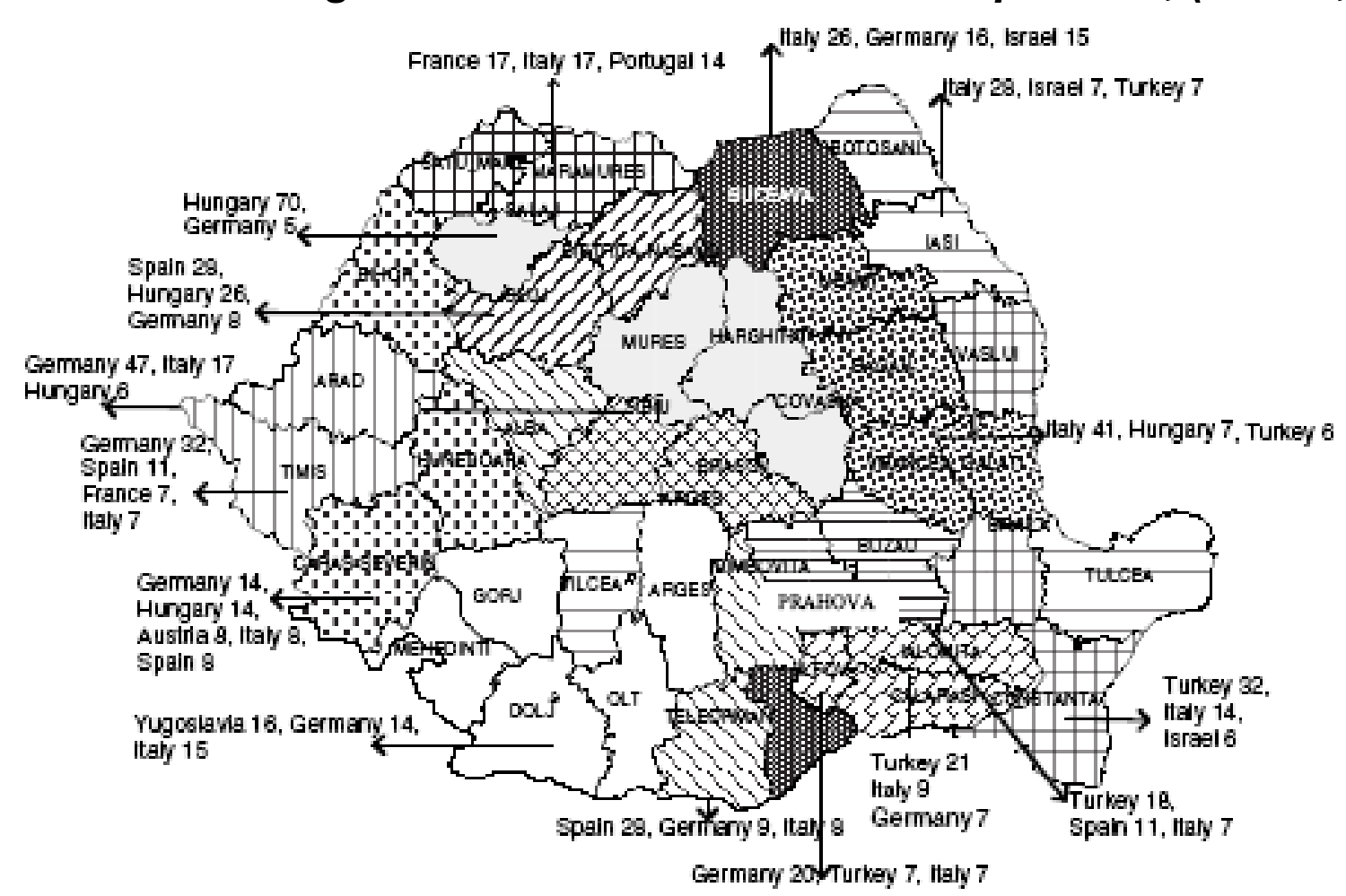

Figure 2 Main Regions of External Circular Migration from Romanian Rural Population Counties with the same hatching have similar profilas of circular migration.

Internal bars of the type —- link counties that are similar in migration profile but discontinucusly placed on the territory. The Internal bars of the type - link counties that are similar in migration profila but discontinuously placed on the territory. The migration profile of a county was determined (through a set of 28 variables measuring he intensity of departing and returning
phenomena towards and from 13 countries (those of first and second rank plus UK [Greece, US and UK not indicated on map]) and two special measurements for the total number of departing and returning persors. The figures next to each country indicate the percentage of circular migration between the Romanian region and the country of reference in the total circular migration associated with the region of oriain. 


\subsection{List of formal and informal organization, groups}

1. MCSZMSZ- Moldvai Csángó Magyarok Szövetsége (Association of Csángó Hungarians in Moldova)

2. Csángók a Csángókért Baráti Kör (Friend of Csángós for Csángós)

3. Szeret-Klézse Alapítvány (Siret-Cleja Foundation)

4. KEMCSE - A Keresztszülők a Moldvai Csángó Magyarokért Egyesület (The Godparents for the Moldavian Csángó Hungarians Association)

5. AMMOA - A Moldvai Magyar Oktatásért Alapítvány (Foundation for the Hungarian Education in Moldova)

6. Szent-István Egyesület (Szent István Union)

7. Via-Spei

8. Főnix Egyesület Forrófalva (Főnix Union Faraoani)

9. A Kisebbségekért - Pro-Minoritate Alapítvány (For the Minorities - Pro Minoritate Foundation) Csángó Committee of Moldova

10. Teleki Alapítvány (Teleki Foundation)

11. Európa a Csángókért (Europe for Csángós)

12. Malthese Charity Service

13. NEI - Nemzetközi Előkészítő Intézet (International Preparatory Institute)

14. Lakatos Demeter Egyesület (Lakatos Demeter Union)

15. Domokos-Pál Péter Alapítvány (Domokos-Pál Péter Foundation)

16. Pusztinai Házért Alapítvány (Foundation for the house from Pusztina)

17. Somoskai faluhét (Villageweek of Somoska)

18. Magyarfalusi napok (Village days of Magyarfalu)

19. Árpádházi Szent Erzsébet Gimnázium and Fundația Sfânta Elisabeta - Szent Erzsébet Alapítvány (Árpádházi Szent Erzsébet School - Szent Erzsébet Foundation)

20. Gyimesi Szent Erzsébet Gimnáziumi Alapítvány

21. Folk ensembles

22. Priests living and working in Moldova 


\subsection{Statistic of MCSMSZ about the Hungarian teaching in} Moldova, in the academic year of 2010-2011.

\begin{tabular}{|c|c|c|c|c|c|c|c|}
\hline & Locality & $\begin{array}{l}\text { Total } \\
\text { number } \\
\text { enrolled to } \\
\text { national } \\
\text { schools }\end{array}$ & $\begin{array}{l}\text { Total } \\
\text { number } \\
\text { enrolled to } \\
\text { national } \\
\text { kindergart } \\
\text { en }\end{array}$ & \begin{tabular}{|l|}
$\begin{array}{l}\text { Enrolled } \\
\text { (with }\end{array}$ \\
request) to \\
Hungarian \\
classes held \\
in national \\
schools \\
\end{tabular} & $\begin{array}{l}\text { Participa } \\
\text { te only } \\
\text { extra } \\
\text { scholar } \\
\text { educatio } \\
\text { n }\end{array}$ & $\begin{array}{l}\text { Total } \\
\text { number of } \\
\text { children } \\
\text { receiving } \\
\text { Hungaria } \\
\text { n } \\
\text { education } \\
\end{array}$ & $\begin{array}{l}\text { Children } \\
\text { participat } \\
\text { ing } \\
\text { Hungaria } \\
\text { n classes } \\
\%\end{array}$ \\
\hline 1. & Bákó & 30.000 & 6.000 & 4 & 10 & 14 & 0,3 \\
\hline 2. & Bogdánfalva & 271 & 45 & 0 & 30 & 30 & 10,5 \\
\hline 3. & Buda & 219 & 84 & 41 & 35 & 76 & 25,3 \\
\hline 4. & Csík falu & $43^{255}$ & 35 & 24 & 74 & 98 & \\
\hline 5. & Diószeg & 212 & 111 & 0 & 42 & 42 & 13 \\
\hline 6. & Diószén & 450 & 100 & 30 & 60 & 90 & 20,5 \\
\hline 7. & Dumbravén & 0 & 22 & $0^{256}$ & 9 & 42 & \\
\hline 8. & Ferdinándújfalu & 350 & 100 & 0 & 18 & 18 & 5 \\
\hline 9. & Frumósza & 400 & 139 & 80 & 38 & 118 & 36,5 \\
\hline 10. & Gajdár & 168 & 27 & 17 & 88 & 105 & 53,8 \\
\hline 11. & Klézse and Tyúkszer & 318 & 100 & 33 & 45 & 78 & 18,8 \\
\hline 12. & Kostelek & 38 & 17 & 38 & $20^{257}$ & 58 & \\
\hline 13. & Külsörekecsin & 266 & 35 & 214 & 21 & 235 & 78,1 \\
\hline 14. & Lábnyik & 142 & 44 & 103 & 22 & 125 & 67,9 \\
\hline 15. & Lészped and Rácsila & 507 & 169 & 112 & 35 & 147 & 22,2 \\
\hline 16. & Lujzikalagor & 430 & 132 & 0 & 76 & 76 & 13,8 \\
\hline 17. & Magyarfalu & 161 & 50 & 139 & 30 & 169 & 80,1 \\
\hline 18. & Nagypatak & 178 & 50 & 7 & 26 & 33 & 15,2 \\
\hline 19. & Pokolpatak & $33^{258}$ & 35 & 0 & 48 & 48 & \\
\hline 20. & Pusztina & 111 & 37 & 54 & 15 & 69 & 46,6 \\
\hline 21. & Somoska & 170 & 53 & 43 & 38 & 81 & 36,7 \\
\hline 22. & Szitás & 120 & 20 & 0 & 40 & 40 & 28,6 \\
\hline 23. & Trunk & 164 & 42 & 44 & 57 & 101 & 49,5 \\
\hline \multicolumn{4}{|c|}{ TOTAL: } & 983 & 877 & 1860 & \\
\hline 24. & $\begin{array}{l}\text { Higher education in } \\
\text { Hungarian schools }\end{array}$ & $\begin{array}{r}(63 \mathrm{~h} \\
\text { univers }\end{array}$ & $\begin{array}{r}73 \\
\text { gh school, } 8 \\
\text { ities, 2 NEI) }\end{array}$ & & & 73 & \\
\hline
\end{tabular}

\footnotetext{
255 only 1-4 classes are in the village

256 They are going to school at Külsőrekecsin

257 older generation

258 only 1-4 classes are in the village
} 


\subsection{Centrality measures I.}

\begin{tabular}{|c|c|c|c|c|c|}
\hline $\begin{array}{l}\text { Actors } \\
\text { appearing in } \\
\text { the networks }\end{array}$ & $\begin{array}{l}\text { Network of } \\
\text { interviewed } \\
\text { elites }\end{array}$ & $\begin{array}{l}\text { Network of } \\
\text { elites and } \\
\text { alters } \\
\text { named by } \\
\text { them }\end{array}$ & $\begin{array}{l}\text { Network of } \\
\text { elites, leader } \\
\text { representatives } \\
\text { and alters }\end{array}$ & $\begin{array}{l}\text { Network of } \\
\text { elites, } \\
\text { representative } \\
\text { and alters }\end{array}$ & $\begin{array}{c}\text { Network of } \\
\text { elites, } \\
\text { representatives } \\
\text { and alters. All } \\
\text { named } \\
\text { relations }\end{array}$ \\
\hline $\begin{array}{l}\text { Total number } \\
\text { of actors }\end{array}$ & 27 & 184 & 358 & 482 & 482 \\
\hline $\begin{array}{l}\text { Total number } \\
\text { of relations }\end{array}$ & 96 & 353 & 632 & 946 & 1777 \\
\hline $\begin{array}{l}\begin{array}{l}\text { Centrality } \\
\text { (degree) }^{259}\end{array} \\
\text { According to } \\
\text { the total } \\
\text { number of } \\
\text { relations } \\
\text { (assuming } \\
\text { symmetric } \\
\text { networks) }\end{array}$ & $\begin{array}{l}\mathrm{S} 2=14 \\
\mathrm{~S} 7=13 \\
\mathrm{~S} 4=11 \\
\mathrm{~S} 5=9\end{array}$ & $\begin{array}{l}\mathrm{S} 2=34 \\
\mathrm{~S} 7=32 \\
\mathrm{~S} 3=31 \\
\mathrm{~S} 1=22\end{array}$ & $\begin{array}{l}\text { S10 }=172 \\
\text { S9 }=64 \\
\text { S }=48 \\
\text { S2 }=34 \\
\text { S3 }=33 \\
\text { S7 }=31 \\
\text { S1 } 1=26 \\
\text { S } 1=22 \\
\text { S12 }=22 \\
\text { S5 }=22\end{array}$ & $\begin{array}{l}\text { S10 }=172 \\
\text { S18 }=68 \\
\text { S9 }=64 \\
\text { S19 }=53 \\
\text { S20 }=51 \\
\text { S8 }=48 \\
\text { S3 }=37 \\
\text { S2 }=34 \\
\text { S7 }=31 \\
\text { S2 } 1=31\end{array}$ & $\begin{array}{l}\text { S10 }=172 \\
\text { S9 }=68 \\
\text { S19 }=68 \\
\text { S18 }=68 \\
\text { S20 }=50 \\
\text { S8 }=49 \\
\text { S2 }=38 \\
\text { S12 }=37 \\
\text { S7 }=36 \\
\text { S3 }=34\end{array}$ \\
\hline $\begin{array}{l}\begin{array}{l}\text { Centrality } \\
(\text { In-degree })^{260}\end{array}\end{array}$ & $\begin{array}{l}\text { S4 }=11 \\
\text { S2 }=11 \\
\text { S } 7=7 \\
\text { S5 }=7\end{array}$ & $\begin{array}{l}\text { S4=11 } \\
\text { S2 }=11 \\
\text { S } 7=7 \\
\text { S5 }=7\end{array}$ & $\begin{array}{l}\text { S4 }=13 \\
\text { S2 }=12 \\
\text { S16 }=11 \\
\text { S5 }=10 \\
\text { S1 } 1=9 \\
\text { S15 }=9 \\
\text { S7 }=8 \\
\text { S14 }=8 \\
\text { S13 }=8 \\
\text { S10 }=7\end{array}$ & $\begin{array}{l}\mathrm{S} 10=17 \\
\mathrm{~S} 25=14 \\
\text { S26 }=14 \\
\mathrm{~S} 4=13 \\
\mathrm{~S} 22=13 \\
\mathrm{~S} 13=13 \\
\mathrm{~S} 23=13 \\
\mathrm{~S} 2=12 \\
\mathrm{~S} 15=11 \\
\mathrm{~S} 16=11\end{array}$ & $\begin{array}{l}\text { S9 }=36 \\
\text { S3 }=32 \\
\text { S2 }=26 \\
\text { S5 }=24 \\
\text { S27 }=23 \\
\text { S12 }=23 \\
\text { S7 }=23 \\
\text { S16 }=22 \\
\text { S22 }=19 \\
\text { S17 }=18\end{array}$ \\
\hline $\begin{array}{l}\begin{array}{l}\text { Centrality } \\
\text { (betweenness) }\end{array}\end{array}$ & $\begin{array}{l}\text { S2 }=126,692 \\
\text { S7 }=111,132 \\
\text { S3 }=61,142 \\
\text { S6 }=59,958 \\
\text { S4 }=57,183\end{array}$ & $\begin{array}{l}\text { S2 }=1604,735 \\
\text { S3 }=1001,724 \\
\text { S7 }=842,698 \\
\text { S4 }=581,405 \\
\text { S6 }=527.856\end{array}$ & $\begin{array}{l}\text { S10 }=4328.730 \\
S 9=2305.019 \\
\text { S2 }=1494.684 \\
S 6=1240.712 \\
\text { S2 } 4=948.721 \\
\text { S } 1=904.946 \\
S 7=870.061 \\
\text { S } 8=841.753 \\
\text { S3 }=676.713 \\
\text { S4 }=673.919\end{array}$ & $\begin{array}{l}\text { S10 }=10280.754 \\
\text { S }=3710.776 \\
\text { S2 }=2291.531 \\
\text { S6 }=1986.072 \\
\text { S18 }=1650.017 \\
\text { S12 }=1494.173 \\
\text { S24 }=1356.187 \\
\text { S7 }=1346.400 \\
\text { S20 }=1305.205 \\
\text { S8 }=1263.689\end{array}$ & $\begin{array}{l}\text { S10 }=31131.945 \\
\text { S }=20357.643 \\
\text { S12 }=6895.139 \\
\text { S8 }=6587.852 \\
\text { S3 }=6316.830 \\
\text { S17 }=5567.668 \\
\text { S28 }=5192.999 \\
\text { S1 }=4298.740 \\
\text { S6 }=4516.147 \\
\text { S20 }=4103.061\end{array}$ \\
\hline $\begin{array}{l}\text { Egonet } \\
\text { Broker }^{262}\end{array}$ & $\begin{array}{l}\mathrm{S} 5=17 \\
\mathrm{~S} 6=16 \\
\\
\mathrm{~S} 7=49 \\
\mathrm{~S} 2=44 \\
\mathrm{~S} 4=33\end{array}$ & $\begin{array}{l}\text { S5 }=89 \\
\text { S3 }=75 \\
\text { S6 }=52 \\
\\
\\
\text { S2 }=241 \\
\text { S4=107 } \\
\text { S7 }=171\end{array}$ & $\begin{array}{l}S 10=1115 \\
\text { S2 }=255 \\
\text { S8 }=106 \\
\text { S12 }=73 \\
\text { S6 }=69 \\
\text { S9 }=364 \\
\text { S7 }=180 \\
\text { S1 }=145 \\
\text { S3 }=123 \\
\text { S4 }=121\end{array}$ & $\begin{array}{l}S 10=2689 \\
S 18=359 \\
S 2=255 \\
S 19=254 \\
S 12=165 \\
\\
S 9=364 \\
S 3=239 \\
S 7=180 \\
S 11=145 \\
S 4=121\end{array}$ & $\begin{array}{l}\text { S10 }=2691 \\
\text { S9 }=2124 \\
S 3=623 \\
\text { S2 }=574 \\
\text { S7 }=565 \\
\text { S8 }=403\end{array}$ \\
\hline
\end{tabular}

\footnotetext{
${ }^{259}$ The number of direct ties a specific actor has. (showing to or from it)

${ }^{260}$ The number of direct ties showing to the specific actor

${ }^{261}$ Assumes that an actor is successful if links together groups or group members that don't know each other directly.

${ }^{262}$ the number of non-directly connected pairs
} 
9.7. Centrality measures II.

\begin{tabular}{|c|c|c|c|c|}
\hline & MCSMSZ & MCSMSZ office & Barátikör & $\begin{array}{l}\text { Hypothetical } \\
\text { network: by } \\
\text { excluding S10 }\end{array}$ \\
\hline $\begin{array}{l}\text { Actors } \\
\text { appearing in the } \\
\text { network }\end{array}$ & $\begin{array}{l}\text { MCSMSZ } \\
\text { employees and } \\
\text { their relations }\end{array}$ & 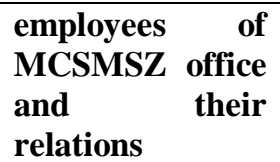 & $\begin{array}{l}\text { members of Csángók } \\
\text { a Csángókért } \\
\text { Barátikör and their } \\
\text { relations }\end{array}$ & $\begin{array}{l}\text { all relations } \\
\text { except those who } \\
\text { were named by } \\
\text { S10. }\end{array}$ \\
\hline $\begin{array}{l}\text { Total number of } \\
\text { relations }\end{array}$ & 617 & 230 & 142 & 760 \\
\hline $\begin{array}{l}\text { Centrality } \\
\text { (degree) } \\
\text { According to the } \\
\text { total number of } \\
\text { relations } \\
\text { (assuming } \\
\text { symmetric } \\
\text { networks) }\end{array}$ & $\begin{array}{l}\text { S10 }=171 \\
\text { S19 }=68 \\
\text { S18 }=68 \\
\text { S20 }=50 \\
\text { S3 }=31 \\
\text { S11 }=26 \\
\text { S12 }=24 \\
\text { S22 }=24 \\
\text { S21 }=22 \\
\text { S37 }=22\end{array}$ & $\begin{array}{l}\text { S10 }=170 \\
\text { S22 }=19 \\
\text { S37 }=18 \\
\text { S } 40=15 \\
\text { S36 }=11 \\
\text { S35 }=4 \\
\text { S25 }=4 \\
\text { S26 }=4 \\
\text { S23 }=4 \\
\text { S38 }=3\end{array}$ & $\begin{array}{l}\mathrm{S} 2=28 \\
\mathrm{~S} 7=25 \\
\mathrm{~S} 5=19 \\
\text { S6 }=17 \\
\text { S4 }=15 \\
\text { S34 }=13 \\
\text { S14 }=13 \\
\text { S29 }=9 \\
\text { S31 }=8 \\
\text { S30 }=8\end{array}$ & $\begin{array}{l}\text { S19 }=67 \\
\text { S18 }=67 \\
\text { S9 }=64 \\
\text { S20 }=49 \\
\text { S8 }=48 \\
\text { S2 }=33 \\
\text { S3 }=31 \\
\text { S1 }=28 \\
\text { S7 }=27 \\
\text { S12 }=25\end{array}$ \\
\hline $\begin{array}{l}\text { Centrality } \\
\text { (In-degree) }\end{array}$ & $\begin{array}{l}\text { S25 }=14 \\
\text { S10 }=13 \\
\text { S26 }=11 \\
\text { S22 }=9 \\
\text { S35 }=9 \\
\text { S12 }=8 \\
\text { S36 }=8 \\
\text { S13 }=8 \\
\text { S17 }=7 \\
\text { S19 }=7\end{array}$ & $\begin{array}{l}\mathrm{S} 35=4 \\
\mathrm{~S} 25=4 \\
\mathrm{~S} 26=4 \\
\mathrm{~S} 23=4 \\
\mathrm{~S} 10=3 \\
\mathrm{~S} 22=3 \\
\mathrm{~S} 38=3 \\
\mathrm{~S} 11=3 \\
\mathrm{~S} 13=3 \\
\mathrm{~S} 39=3\end{array}$ & $\begin{array}{l}\text { S4 }=8 \\
\text { S5 }=7 \\
\text { S2 }=6 \\
\text { S14=6 } \\
\text { S32=5 } \\
\text { S34=5 } \\
\text { S33=4 } \\
\text { S9=3 } \\
\text { S13=3 } \\
\text { S7 } 7=3\end{array}$ & $\begin{array}{l}\text { S25 }=13 \\
\text { S2 }=12 \\
\text { S4 }=12 \\
\text { S26 }=12 \\
\text { S13 }=12 \\
\text { S16 }=11 \\
\text { S22 }=10 \\
\text { S15 }=10 \\
\text { S5 }=10 \\
\text { S23 }=10\end{array}$ \\
\hline $\begin{array}{l}\text { Centrality } \\
\text { (betweeness) }\end{array}$ & $\begin{array}{l}S 10=3827.259 \\
S 12=681.435 \\
\text { S19 }=627.335 \\
\text { S18 }=571.510 \\
\text { S20 }=528.065 \\
\text { S3 }=351.100 \\
\text { S17 }=256.141 \\
\text { S21 }=249.700 \\
\text { S1 }=239.917 \\
\text { S28 }=229.195\end{array}$ & $\begin{array}{l}\text { S10 }=499.833 \\
\text { S22 }=36.833 \\
\text { S37 }=24.333 \\
\text { S40 }=15.000 \\
\text { S36 }=5.000\end{array}$ & $\begin{array}{l}S 2=202.767 \\
S 4=197.533 \\
\text { S6 }=124.700 \\
\text { S5 }=112.333 \\
\text { S7 }=93.333 \\
\text { S34 }=72.717 \\
\text { S29 }=36.000 \\
\text { S14 }=33.167 \\
\text { S3 }=33.000 \\
\text { S30 }=24.450\end{array}$ & $\begin{array}{l}S 9=5242.124 \\
S 11=2000.684 \\
\text { S19 }=1963.269 \\
\text { S7 }=1850.276 \\
\text { S18 }=1787.201 \\
\text { S28 }=1783.011 \\
\text { S27 }=1619.625 \\
\text { S22 }=1534.780 \\
\text { S2 }=1423.107 \\
\text { S3 }=1347.680\end{array}$ \\
\hline Egonet Broker & $\begin{array}{l}S 10=2066 \\
S 19=344 \\
\text { S18 }=289 \\
\text { S3 }=144\end{array}$ & $\begin{array}{l}\text { S10 }=482 \\
\text { s22 }=38 \\
\text { S37 }=19 \\
\text { S36 }=5 \\
\text { S40 }=5\end{array}$ & $\begin{array}{l}\mathrm{S} 2=124 \\
\mathrm{~S} 5=81 \\
\mathrm{~S} 4=73 \\
\mathrm{~S} 7=52\end{array}$ & $\begin{array}{l}S 19=297 \\
S 9=278 \\
S 18=242 \\
S 2=231 \\
\text { S8 }=73\end{array}$ \\
\hline
\end{tabular}




\subsection{Half structured interview}

A moldvai csángó elit kialakulása a migráció következtében

A következő kérdések, csupán útbaigazítóként szolgálnak, az interjú vezérfonalát alkotják. A kérdések a

1. Kérem meséljen kicsit az életéről: melyek voltak a fontosabb események, helyszínek. Kik azok, akik fontos szerepet töltöttek be abban, hogy Ön azzá és olyanná vált aki.

2. Amennyiben élt külföldön is kérem meséljen arról hogyan kerültel otthonról! Milyen céllal és hova utazott? Mennyi ideig élt ott?

3. Mindig is szeretett volna külföldre menni? Miért? Miért nem?

4. Ki vagy kik segítették abban, hogy megszervezze, megvalósítsa a kiutazást?

5. Változott-e valamit az Ön élete amióta először elkerült otthonról?

6. Tanácsolná a fiatal csángóknak, hogy külföldön próbáljanak szerencsét vagy inkább arra bíztatná, hogy maradjanak az ország határain belül?

7. Amióta külföldön él segített rokonoknak, falubelieknek, más csángóknak, hogy ők is kiutazzanak?

8. Minek van nagyobb előnye a tanulásnak vagy a munkának?

9. Beszélhetünk-e csángó értelmiségről? És Csángó elitről? Létező csoportokról beszélünk? Kérem fejtse ki. 


\subsection{Questionnaire}

FIŞĂ DE DATE

INTREBĂRILE SE REFERĂ LA GOSPODĂRIA D-VOASTRĂ RĂSPUNSUL ESTE VOLUNTAR SI ANONIM

Numele localitătii:

Data intrebării: ziua $\quad$ luna $\quad$ anul

ritul chestionarului: ora minutul

$\underline{\text { Stratificarea satelor catolice din Moldova și migrarea internatională }}$

\section{ADATLAP}

A KÉRDÉSEK AZ ÖN HÁZTARTÁSÁRA VONATKOZNAK A VÁLASZADÁS ÖNKÉNTES ÉS NÉVTELEN

Település neve:

Kérdezés ideje:

Kérdezés kezdete:

Kérdezés vége: év hónap nap

ora

Moldvai katolikus falvak társadalomszerkezete és a külföldi migráció

A kutatásról röviden: A kutatás egy folyamatban lévő doktori disszertáció empirikus részét képezi melyet Kónya Hanna a Budapesti Corvinus Egyetem Ph.D. hallgatója végez Letenyei László (BCE) és Jose Luis Molina, az Universidad Autonoma de Barcelona oktatójának szakirányítása mellett. A kutatási eredmények a nevezett hallgató doktori disszertációjában kerülnek feldolgozásra.

A kutatás célja: Jelen kérdőív egy tágabb kutatás része, melyben a Moldvai katolikus települések társadalomszerkezetét, a külföldi munkavállalást, külföldi továbbtanulást vizsgáljuk a Moldvai csángók körében. Kutatásunk arra keresi a választ, hogy a rendszerváltással elterjedtté vált külföldi migráció (munkavállalás és tanulási lehetőségek szélesebb palettája) milyen módon vezet el a csángó értelmiség és a csángó (gazdasági) elit megjelenéséhez kialakulásához

Kulcsszavak: Társadalomszerkezet, Külföldi vendégmunka, elit-kialakulás, migráció, gazdaságszociológia, határokon túlmutató kapcsolatok 


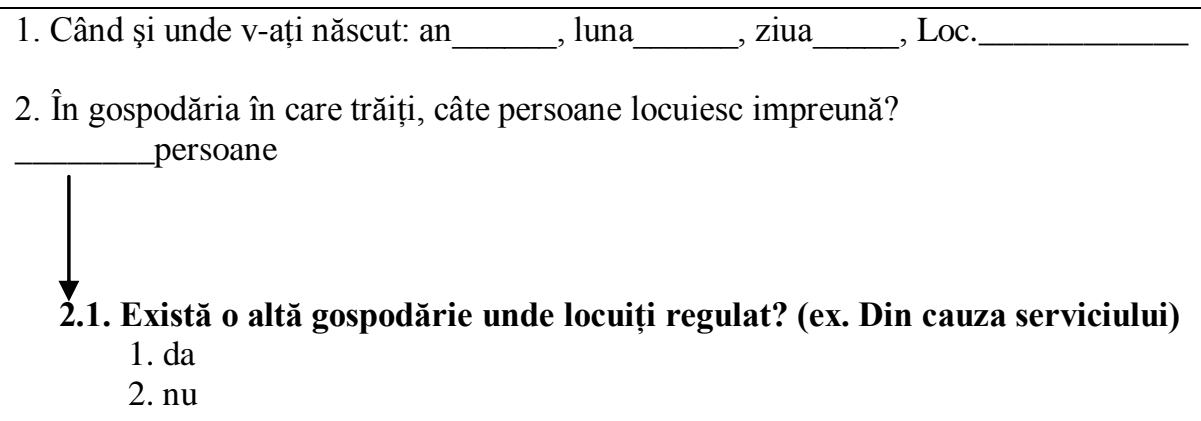

3. Vă rog să-mi spuneți câteva date despre persoanele cu care locuiții impreună: (Un rand reprezinta o ruda)

\begin{tabular}{|l|l|l|l|l|}
\hline NO. & Rudeni & $\begin{array}{l}\text { Gen } \\
(1 \text { Masc., 2 Fem. })\end{array}$ & $\begin{array}{l}\text { Data şi locul de } \\
\text { naştere }\end{array}$ & Ocupația \\
\hline 1. & & & & \\
\hline 2. & & & & \\
\hline 3. & & & & \\
\hline 4. & & & & \\
\hline 5. & & & & \\
\hline 6. & & & & \\
\hline 7. & & & & \\
\hline 8. & & & & \\
\hline 9. & & & & \\
\hline 10. & & & & \\
\hline
\end{tabular}

\section{Rudenie:}

01. sot, soție

02. copil comun

03. copil din altă relaţie

04. copil al rudelor

05. părinte, soacră, socru

06. noră, ginere

07. nepot

08. frate, soră

\author{
Ocupatie: \\ 1. angajat \\ 2. independent, intreprinzător \\ 3. membru de asociație agricola,etc. \\ 4. şomer \\ 5. concediu de maternitate, etc \\ 6. pensionar (de boală) \\ 7. casnic
}

8. elev, preşcolar, etc

1. Mikor és hol született Ön:

év

hónap

nap,

település

2.Abban a háztartásban ahol jelenleg él Önnel együtt hányan laknak fö

1

2.1.Van-e más háztartás ahol rendszeresen szokott lakni?(pl. munka miatt)

1. van

2. nincs

3.Kérem közöljön az Önnel együtt lakókról néhány adatot:

(Egy sor egy rokont jelöl)

\begin{tabular}{|l|l|l|l|l|}
\hline NO. & $\begin{array}{l}\text { Rokonsági } \\
\text { viszony }\end{array}$ & $\begin{array}{l}\text { Nem } \\
\text { (1 Férfi, 2 Nö) }\end{array}$ & $\begin{array}{l}\text { Születési idő és } \\
\text { hely }\end{array}$ & $\begin{array}{l}\text { Kereső } \\
\text { tevékenység }\end{array}$ \\
\hline 1. & & & & \\
\hline 2. & & & & \\
\hline 3. & & & & \\
\hline 4. & & & & \\
\hline 5. & & & & \\
\hline 6. & & & & \\
\hline 7. & & & & \\
\hline 8. & & & & \\
\hline 9. & & & & \\
\hline 10. & & & & \\
\hline
\end{tabular}

\section{Rokonsági viszony:}

01. házastárs

02. jelenlegi társsal közös gyerek

03. korábbi partnertől származó gyerek

04. rokon gyereke

05. szülö, anyós, após

06. menye, veje

07. unoka

08. testvér

\section{Kereső tevékenység}

1. alkalmazott

2. önálló, vállalkozó

3. szövetkezeti tag

4.munkanélküli

5.gyereknevelés, szülésszabadság

6.nyugdíjas, betegnyugdíjas

7.háztartásbeli

8. tanuló, óvodás, stb. 


\begin{tabular}{|c|c|c|c|c|}
\hline \multirow{2}{*}{\multicolumn{5}{|c|}{$\begin{array}{l}\text { 09. bunic, bunică } \\
\text { 4. Ce studii ați terminat? }\end{array}$}} \\
\hline & & & & \\
\hline \multicolumn{2}{|l|}{ 1.nu am făcut şcoală } & \multicolumn{3}{|c|}{ 6.postliceală } \\
\hline \multicolumn{2}{|l|}{ 2. mai puțin de 8 clase } & \multicolumn{3}{|c|}{ 7.şcoală tehnică superioară } \\
\hline \multicolumn{2}{|l|}{3.8 clase } & \multicolumn{3}{|c|}{ 8.facultate } \\
\hline \multicolumn{2}{|l|}{ 4. profesională (10 clase) } & \multicolumn{3}{|c|}{ 9.postuniversitar (MA,PhD) } \\
\hline \multicolumn{2}{|l|}{ 5. bacalaureat } & \multicolumn{3}{|c|}{ 10. în prezent } \\
\hline \multicolumn{5}{|c|}{ 5. În ce limba ați învățat sau învățati? } \\
\hline Inc e limba ati invatat in... & Română & Maghiară & $\begin{array}{l}\text { Mixtă } \\
\text { /alta }\end{array}$ & $\begin{array}{l}\text { Nu am studiat } \\
\text { Nu sti }\end{array}$ \\
\hline 1. gradiniță? & 1 & 2 & 3 & 9 \\
\hline 2. clasele $1-4$ ? & 1 & 2 & 3 & 9 \\
\hline \multirow{3}{*}{$\begin{array}{l}\text { 3. clasele } 58 \\
\text { 4. liceu sau profesională? } \\
\text { 5. facultate }\end{array}$} & 1 & 2 & 3 & 9 \\
\hline & 1 & 2 & 3 & 9 \\
\hline & 1 & 2 & & 9 \\
\hline 6. MA, D & 1 & 2 & 3 & 9 \\
\hline \multicolumn{5}{|c|}{ 6. Actual aveți loc de muncă/sursă de venit? } \\
\hline \multicolumn{2}{|c|}{$\begin{array}{l}\text { 1. da } \\
\text { În ce formă? } \\
\text { 11. angajat } \\
\text { 12. independent, (co)intreprinzător } \\
\text { 13. pensionar şi lucrez } \\
\text { 14. student la zi şi lucrez (permanent/ } \\
\text { ocazional) } \\
\text { 16. muncă ocazională, zilier (fizic) } \\
\text { 17. muncă ocazională intelectuală }\end{array}$} & \multicolumn{3}{|c|}{$\begin{array}{l}\text { 2. nu } \\
\text { Din ce motiv nu lucrati? } \\
\text { 21. pensionar } \\
\text { 22.pensionar de boala } \\
\text { 23.concediu de maternitate } \\
\text { 24. soldat } \\
\text { 25. casnic } \\
\text { 26. elev } \\
\text { 27. işi caută primul loc de muncă } \\
\text { 28. şomer } \\
\text { 29. altceva }\end{array}$} \\
\hline
\end{tabular}

7. Vă rog să-mi spuneți ocupația/ultima ocupație şi locul serviciului:

8. În ce măsură sunteți satisfăcut de serviciul d-voastră?

$\rightarrow 10$

09. nagyszülö 9. egyéb

4. Mi az Ön legmagasabb, befejezett iskolai végzettsége?

6.posztliceális szakképzés

2. kevesebb,mint 8 osztály 7.föiskola, felsőfokú technikum

3. 8 osztály 8.egyetem

4. szakiskola (10 osztály) 9.egyetem utáni képzés (MA,PhD)

5. érettségi $\mathbf{1 0}$. folyamatban van a

5. Tekintsük át, hogy Ön milyen nyelven végezte/végzi tanulmányait: Milyen nyelven tanult...

1. az óvodában?

2. z 1-4 osztályban

3. az 5-8 osztályban

4. a 9-10 vagy 9-12-ben

5. föiskolán, egyetemen

6. $\mathrm{MA}, \mathrm{PhD}$

\begin{tabular}{|c|c|c|c|}
\hline Románul & $\begin{array}{c}\text { Ma ya } \\
\text { l }\end{array}$ & $\begin{array}{l}\text { Vegyes } \\
\text { /más }\end{array}$ & $\begin{array}{l}\text { Nem járt } \\
\text { Nem tudja }\end{array}$ \\
\hline 1 & 2 & 3 & 9 \\
\hline 1 & 2 & 3 & 9 \\
\hline 1 & 2 & 3 & 9 \\
\hline 1 & 2 & 3 & 9 \\
\hline 1 & 2 & 3 & 9 \\
\hline 1 & 2 & 3 & 9 \\
\hline
\end{tabular}

6. Jelenleg végez-e valamilyen kereső munkát

1. igen

Milyen formában?

11. alkalmazott

12. önálló, vállalkozó, társvállalkozó

13.nyugdíjas és kereső munkát is végez

14. nappali tagozaton tanul és mellette

dolgozik (állandó/alkalmi)

16. alkalmi munkából él, napszámos

(fizikai)

17. megbízásból él (szellemi)

2. nem

Miért nem dolgozik?

21. öregségi nyugdíjas

22.rokkant nyugdíjas

23.szülési/gyermeknevelési szabadság

24. katona

25. háztartásbeli

26. tanuló

27. első állását keresi

28. munkanélküli

29. egyéb

7. Kérem mondja meg, az Ön jelenlegi/utolsó foglalkozását és annak helyét:

8. Mennyire elégedett jelenlegi munkahelyével? 


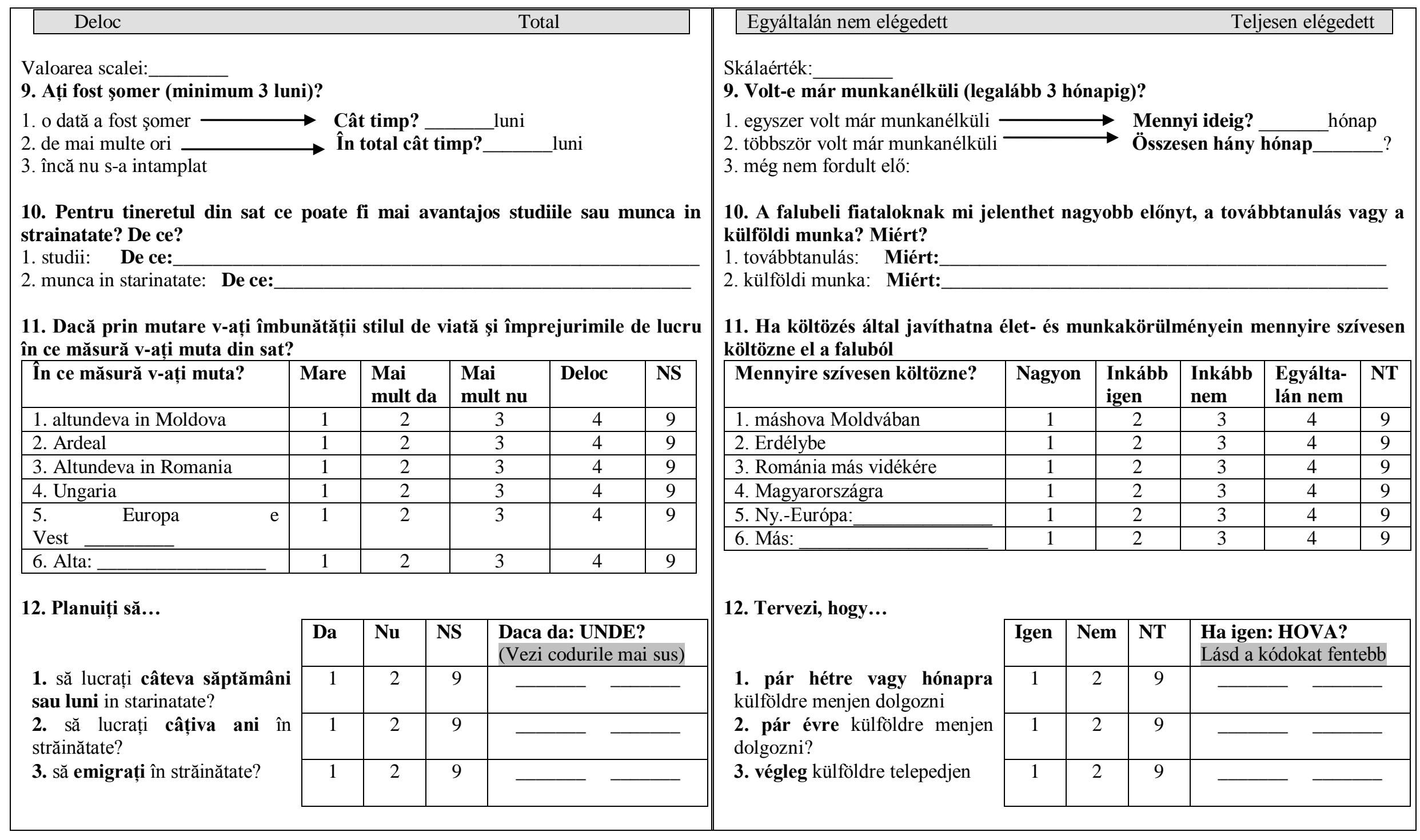


13. Daca cineva din familie vrea sa lucreze în străinătate pe ajutorul cui puteți conta? (ajutor: informatii, relatii, expreiente personale...)

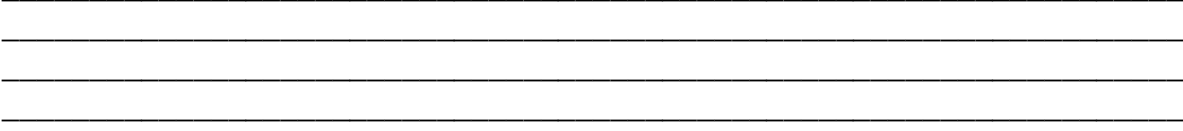

$\overline{\text { 14. Trăiește cineva din familia dumneavoastră mai mult de un an în străinătate? }}$

$$
\text { 1. da }
$$$$
\text { 2. nu }
$$

Vă rog să-mi spuneți câteva date despre ei:

\begin{tabular}{|c|c|c|c|c|c|c|}
\hline & Rudenia & Ţara & $\begin{array}{l}\text { De când } \\
\text { stă acolo? }\end{array}$ & Ocupația & $\begin{array}{l}\text { Şcoala } \\
\text { terminată }\end{array}$ & $\begin{array}{l}\text { Are cetățenia? } \\
\text { 1.da, } 2 . n u, \\
9 \text { NS }\end{array}$ \\
\hline 1. & & & & & & \\
\hline 2. & & & & & & \\
\hline 3. & & & & & & \\
\hline 4. & & & & & & \\
\hline 5. & & & & & & \\
\hline 6. & & & & & & \\
\hline 7. & & & & & & \\
\hline 8. & & & & & & \\
\hline 9. & & & & & & \\
\hline 10 & & & & & & \\
\hline
\end{tabular}

\begin{tabular}{|l|l|l|}
\hline Rudenia: & Tara: & Ocupatie \\
1. casnicie & 1.Ungaria & 1. angajat \\
2. copil & 2. Italia & 2.independent,interprinzator \\
3. frate, sora & 3. Spania & 3. membru de asociatie \\
4. parinte & 4 Germania, Austria & 4. somer \\
5. bunici & 5. Franta & 5. concediu de maternitate \\
6 socru, soacra & 6. Izrael & 6.pensionar(de boala) \\
7. nora, ginere & 7. Anglia, Irlanda & 7. casnic, casnica \\
8. nepot & 8. USA, Canada & 8. elev, prescolar, etc. \\
9 alta ruda (apropiata) & 9. alta tara & 9. altceva \\
\hline
\end{tabular}

13. Ha valaki a családjából külföldre szeretne menni dolgozni kinek a segítségére számíthat? (segítség: információ, kapcsolatok, egyéni tapasztalatok...)

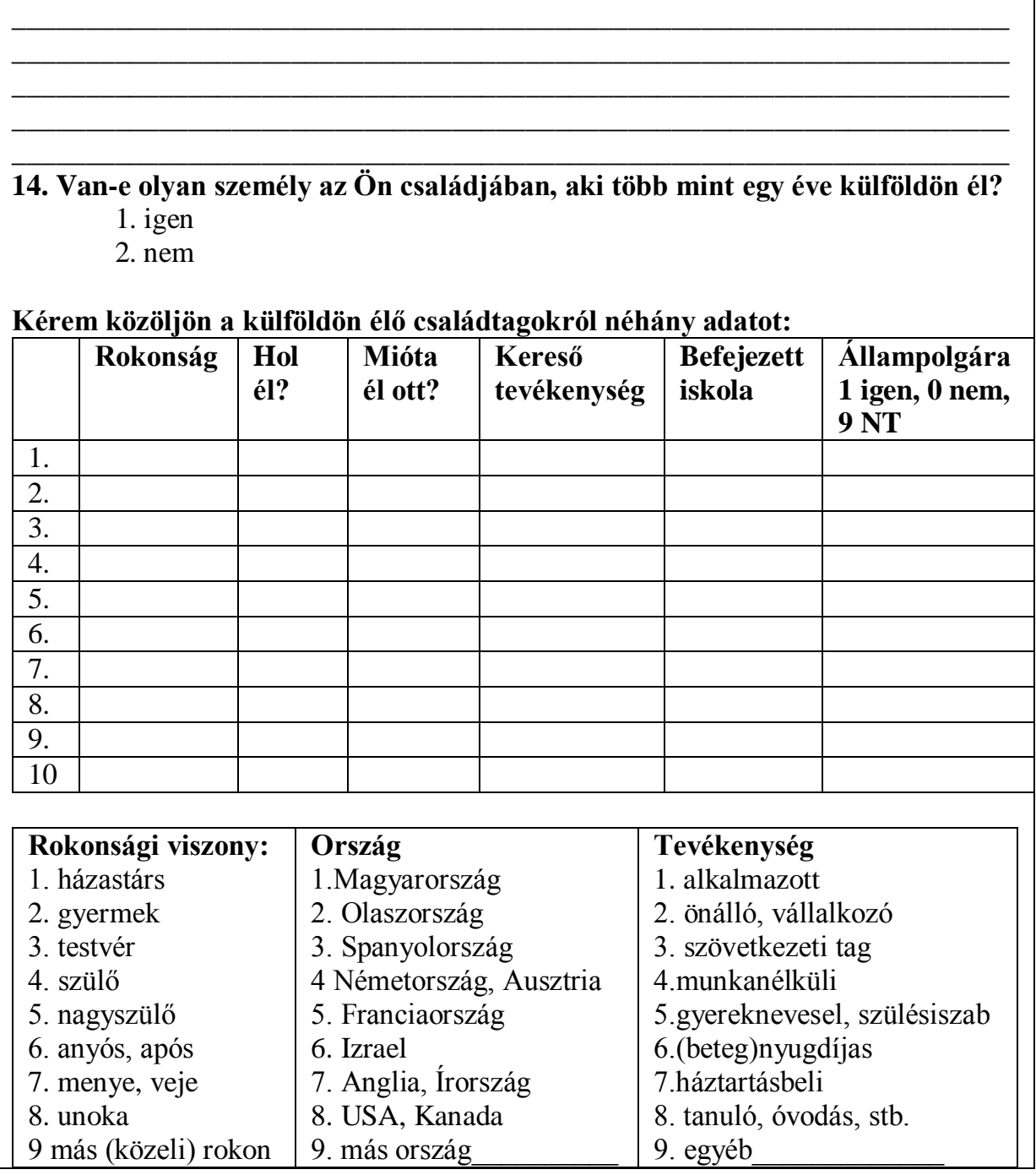




\begin{tabular}{|c|c|}
\hline $\begin{array}{ll}\text { Scoala terminată } & \\
\text { 1. nu a făcut şcoală } & \text { 6.postliceală } \\
\text { 2. mai puțin de } 8 \text { clase } & \text { 7. şcoală tehnică superioară } \\
\text { 3. } 8 \text { clase } & \text { 8.facultate } \\
\text { 4. profesională (10 clase) } & \text { 9.postuniversitar (MA,PhD) } \\
\text { 5. bacalaureat } & \mathbf{1 0 . \text { în prezent }} \\
\end{array}$ & $\begin{array}{ll}\text { Befejezett iskola } & \\
\text { 1.nem járt iskolába } & \text { 6.posztliceális szakképzés } \\
\text { 2. kevesebb,mint } 8 \text { osztály } & \text { 7.föiskola, felsőfokú technikum } \\
\text { 3. } 8 \text { osztály } & \text { 8.egyetem } \\
\text { 4. szakiskola (10 osztály) } & \text { 9.egyetem utáni képzés (MA,PhD) } \\
\text { 5. érettségi } & \mathbf{1 0 . \text { folyamatban van a }} \\
\end{array}$ \\
\hline $\begin{array}{l}\text { 15. In sat pe cine considerati elita? (Cine sunt aceia care s-au ridicat din } \\
\text { majoritate? Ci sunt cei care pot fi exemple de urmat pentru tineretul din sat?) }\end{array}$ & $\begin{array}{l}\text { 15. A faluban kit tekint elitnek és miért? ( } \mathrm{Ki} \text { az aki kiemelkedett a többségböl? Ki } \\
\text { az aki jó példaként szolgálhat a falusi fiataloknak?) }\end{array}$ \\
\hline 16. Ce caractersitici trebuie sa indeplineasca cineva ca sa fie considerat elita? & 16. Milyen jellemzői kell legyenek valakinek ahhoz, hogy elitnek tekintse? \\
\hline $\begin{array}{l}\text { 17. Va rog denumiti } 10 \text { persoane din sat, despre care credeti ca au cel mai mare } \\
\text { respect . } \\
1 .\end{array}$ & $\begin{array}{l}\text { 17. Kérem nevezze meg azt a } 10 \text { embert, akit Ön szerint a faluban a legjobban } \\
\text { tisztelnek: } \\
\text { 1. }\end{array}$ \\
\hline 2. & 2. \\
\hline 3. & 3. \\
\hline 4. - & $\begin{array}{l}4 . \\
5\end{array}$ \\
\hline 6. & 6. \\
\hline 7. & 7. \\
\hline 8. & 8. \\
\hline 9. & 9. \\
\hline 10. & 10. \\
\hline Va multumesc pentru ajutor! & Köszönöm a segítségét! \\
\hline
\end{tabular}




\section{Publications}

Scientific book, book chapter

2010

The appearance of the Moldavian Csángó Elite as a Consequence of Transnational Migration in Tanya Chavdarova, Petya Slavova and Svetla Stoeva (ed) (2010) Markets as Networks, St. Kliment Ohridski University Press, Sofia , pp. 217-228

Peer reviewed journal

2012

Kapcsolati tőke, földrajzi kettősség és a csángó elit. in Terek a társadalomban. Belvedere Meridionale. Történelem és Társadalomtudományok. XXIV évfolyam, 1. szám, pp. 80-92

2006.

Új rétegződésmodell kialakítására tett kísérlet (recenzió Kabai Imre: Társadalmi rétegződés és életesemények. A magyar fiatalok a posztindusztriális korszakban című könyvéről p. 294., Budapest, 2006, ÚMK.) in WEB Fesztiválok ifjúsága, 14-15. összevont szám, 2006/1-2

2003

Szegénységkutatás egy falusi roma közösségben, WEB A Max Weber Szociológiai Szakkollégium lapja, Kolozsvár., 11 szám 2003 C. 10 pont

2011

The Prominent Csángó Hub. Key Actors in the Network Structure of the Csángó Elite, Review of Sociology, 2011/4 (Bodor Eranus Elizaval közösen

Other

Egy Fehér megyei falu elitjének kapcsolathálózati elemzése, Magyar Kisebbség. Nemzetpolitikai Szemle, 2005/3.-4. no. (3738.), pp. 369-384 